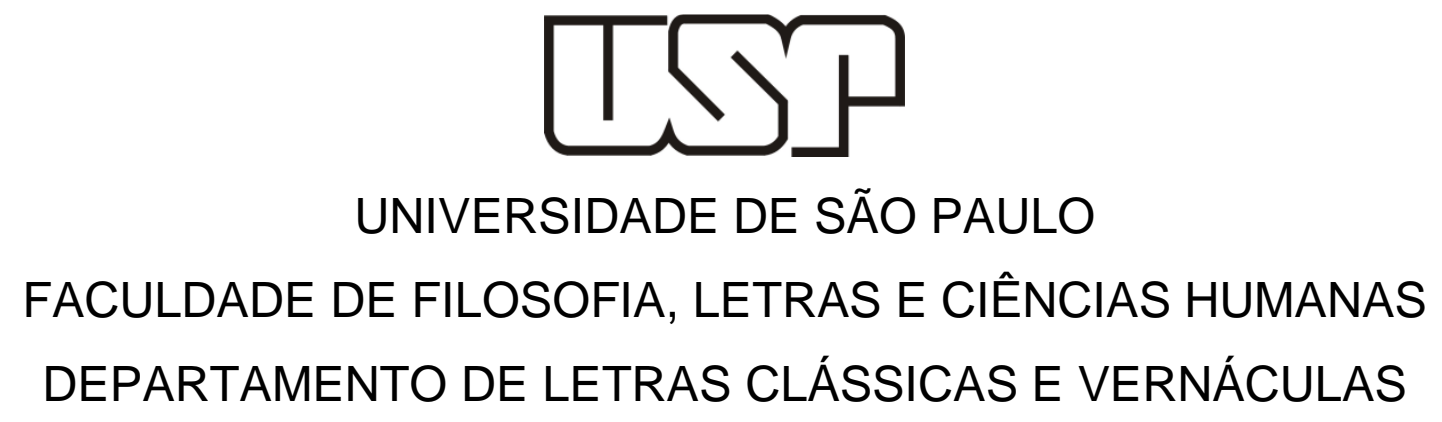

Talita Rodrigues da Silva

\title{
Tempo, aspecto e modalidade em Pykobjê- Gavião (Timbira): a linguística em discussão
} (versão corrigida) 
Talita Rodrigues da Silva

\section{Tempo, aspecto e modalidade em Pykobjê- Gavião (Timbira): a linguística em discussão} (versão corrigida)

Tese submetida ao Departamento de Letras Clássicas e Vernáculas da Universidade de São Paulo, como parte dos requisitos para a obtenção do título de Doutora em Filologia e Língua Portuguesa, sob a orientação da Profa - Dra. Rosane de Sá Amado.

Apoio: Capes

São Paulo-SP 
Autorizo a reprodução e divulgação total ou parcial deste trabalho, por qualquer meio convencional ou eletrônico, para fins de estudo e pesquisa, desde que citada a fonte.

Catalogação na Publicação Serviço de Biblioteca e Documentação

Faculdade de Filosofia, Letras e Ciências Humanas da Universidade de São Paulo

Silva, Talita Rodrigues da Silva

S586t Tempo, aspecto e modalidade em Pykobjê-Gavião (Timbira): a linguística em discussão / Talita Rodrigues da Silva Silva ; orientador Rosane de Sá Amado Amado. - São Paulo, 2017. $182 \mathrm{f}$.

Tese (Doutorado)- Faculdade de Filosofia, Letras e Ciências Humanas da Universidade de São Paulo. Departamento de Letras Clássicas e Vernáculas. Área de concentração: Filologia e Língua Portuguesa.

1. Linguística. 2. Língua indígena. 3. Morfologia.

4. Sintaxe. 5. Semântica. I. Amado, Rosane de Sá Amado, orient. II. Título. 
Tese apresentada como requisito necessário para a obtenção do título de Doutora em Letras, na área de Filologia e Língua Portuguesa pela Universidade de São Paulo. Qualquer citação atenderá às normas da ética científica.

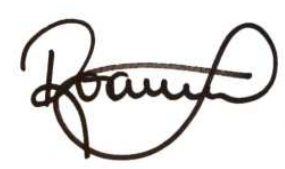

De acordo com as alterações - Prof ${ }^{a}$ Dra. Rosane de Sá Amado

Aprovada em: 21/11/2016

Banca examinadora:

Prof ${ }^{a}$ Dra. Rosane de Sá Amado (Presidente)

Universidade de São Paulo (USP)

Prof ${ }^{a}$ Dra. Flávia de Castro Alves (Titular)

Universidade de Brasília (UnB)

Prof. Dr. Ludoviko Carnascialli dos Santos (Titular)

Universidade Estadual de Londrina (UEL)

Prof ${ }^{a}$ Dra. Márcia Santos Duarte de Oliveira (Titular)

Universidade de São Paulo (USP)

Prof. Dr. Waldemar Ferreira Netto (Titular)

Universidade de São Paulo (USP) 


\section{Dedicatória}

Dedico este trabalho às pessoas que já não estão mais entre nós em corpo, porém deixam um imenso legado de histórias, memórias e vivências, que reverberam em minha formação intelectual, moral e ético-política e, consequentemente, na presente Tese.

Desse modo, agradeço pela oportunidade de ter convivido com minha avó paterna, Laura Gomes Pereira da Silva.

Para mim, ela sempre será a mulher, que lutou para retomar os estudos. Dentre as trajetórias de vida, com as quais teve de lidar, narrava o impedimento de estudar para além das séries iniciais, conforme se dava com seus irmãos. A justificativa, de ordem patriarcal, era a de que as mulheres não precisariam aprender mais do que o básico, pois não haveria utilidade para elas em desenvolver uma boa escrita ou leitura.

Duas gerações adiante, sua neta não somente escreve como também ousa mostrar suas discussões em um grupo de doutores, sonhando ela mesma tornar-se um tanto dout(or)a.

Desse modo, fico com a saudade dessa mulher ousada e que aprendeu, sim, a ler e a escrever e, sobretudo, foi afetada pelo letramento. Desse modo, mais importante do que reaver a técnica negada, minha avó Laura aprendeu a narrar e, com isso, deixar às gerações futuras a escrita-de-si, cujo curto e pontual exemplo retomei acima.

Dedico este trabalho também ao meu avô materno, Martinho Rodrigues. Com ele, aprendi que toda conquista demanda esforços e trabalho, os quais, por sua vez, devem reverberar no coletivo. Pois, segundo sua posição política, traduzida no mais simples "levar a vida", o indivíduo bem sucedido é aquele que consegue contribuir para e por seu grupo.

Meu avô chegou ao Brasil, como tantos outros imigrantes, desprovido de bens materiais e impactado pelo duro período da II Grande Guerra, que assolou a Europa. Com muito empenho, esperança e uma gratidão ímpar pela nova oportunidade de vida, meu avô assumiu o Brasil como sua morada, até os tempos finais. Aqui, casouse e deixou uma bela herança simbólica, a certeza de que todos somos irmãos e, portanto, precisamos nos ajudar. Enquanto viveu, jamais se conformou que 
houvesse fome dentre aqueles que o cercavam. Afinal, por que permitir ao outro uma dor da qual se padeceu?

Com infinito pesar pela ausência e saudade imensurável, dedico ao meu pai, José Carlos da Silva. Neto de um indígena Kariri, foi com ele que aprendi a valorizar as culturas ordinariamente marginalizadas pelo biopoder, dentre as quais destaco os saberes indígenas.

Meu pai foi a primeira pessoa a me levar a uma aldeia indígena. Quando chegamos àquele espaço, desgarrou-se do grupo de "brancos" curiosos, com o qual estávamos, a fim de caminhar com os velhos, indagando sobre suas ervas, crenças, cotidiano e sonhos. Pois, para ele, aquelas pessoas significavam uma oportunidade de troca intercultural e não uma fonte de diversão via contato com elementos exóticos. Uma pena que, na ocasião, estivesse eu junto ao grupo de curiosos, metidos a intelectuais bem intencionados...

Assim, carrego a tristeza por meu pai nunca ter conseguido estar ao meu lado, durante os trabalhos de campo, que culminaram nesta Tese. Este era nosso maior sonho. Contudo, imperou meu medo de que ele experimentasse uma piora em seu quadro de saúde, frente à dinâmica em aldeia, como se a morte não estivesse em toda parte e para todos os povos, igualmente. Ele bem o sabia.

Por fim, dedico a Augusto Gavião, meu interlocutor e companheiro de jornada, através da cultura e língua de seu povo. Homem íntegro, Augusto foi um dos principais incentivadores deste trabalho, enquanto estive na aldeia Governador. De bem material, ainda guardo o magnífico colar que me ofereceu, após um dos festejos. Na ocasião, disse-me que teria sorte por portar aquele objeto e que ele me faria lembrar de que há uma aliança entre este povo e eu.

As alianças nunca se desfizeram e, na verdade, a minha sorte foi ter conhecido e convivido com todos vocês. Mais do que isso, a nossa sorte foi ter aceitado a dádiva de compartilharmos vários projetos, dentre os quais esta Tese. 


\section{Agradecimentos}

Este trabalho é resultado do apoio incondicional, que tenho recebido do povo Gavião e, sobretudo, dos meus interlocutores que, sem cobranças de qualquer ordem, sempre se dispuseram a dedicar parte de seu tempo para conversas e questionários, por vezes, repetitivos e cansativos. Desse modo, agradeço, especialmente, ao professor Paulo, que assumiu esta empreitada como uma tarefa pessoal. Curioso e eterno estudante, Paulo foi o interlocutor que mais partilhou dúvidas e curiosidades linguísticas comigo. Além disso, nunca teve receios de informar que "isso não se diz na minha língua".

Agradeço também aos amigos e interlocutores, Evandro, Edivaldo, Diana, Raquel e ao saudoso Augusto. Obrigada pela disponibilidade e interesse pelas discussões de língua e cultura! Com vocês, tive a oportunidade de aprender muito mais do que as tipologias poderiam prever.

Com saudades, lembro-me da importância dos amigos Carlos e Neci, que me hospedaram na aldeia Gavião. Apesar da atual conjuntura de nossas vidas impossibilitar um contato rotineiro, estou certa de que nossa amizade permanece solidificada. Foi ao longo desta convivência que entendi, finalmente, que meu papel como linguista não teria sentido, uma vez que se descolasse da realidade experienciada por seus falantes.

Nesse sentido, gostaria de expor minha admiração por Jonas Gavião, que há anos tem trabalhado política e ideologicamente pelo bem-estar de seu povo. Ainda que nossas trocas na aldeia tenham sido bastante pontuais, aprendi a admirar e reconhecer sua luta. A partir de sua expressão, compreendi, sobretudo, que não se pode pensar em identidade sem se considerar a formação e a manutenção das diversas formas de poder.

Sem dúvidas, foi no e devido ao contato com cada uma das pessoas supracitadas, que tive a oportunidade de rever minhas posições teóricas, sendo esta Tese o reflexo de tal processo de amadurecimento.

No que concerne aos apontamentos teóricos, muito tenho a agradecer aos docentes que têm contribuído nesta jornada, ao que destaco a participação do Prof. Dr. Gabriel Antunes de Araújo, que compôs a banca de Qualificação ao Mestrado. Seu olhar prático e proposições teóricas foram essenciais para desenhar o caminho nesta linha de análise e, sobretudo, na minha formação enquanto pesquisadora. 
Com afeto e admiração, agradeço também à Profáa. Dra. Márcia Santos Duarte de Oliveira, que tem apresentado ricas sugestões para minha formação acadêmica. Foi essencial contar com sua experiência nos exames de Qualificação ao Mestrado e ao Doutorado, ocasiões em que fui chamada a pensar e, por vezes, repensar os movimentos teóricos de estruturação das proposições de análise. Igualmente enriquecedora, foi sua contribuição na banca de avaliação da Dissertação, da qual trago alguns dos apontamentos, inclusive, para a presente Tese.

Outro parceiro importante, ao longo deste percurso, tem sido o Prof. Dr. Ludoviko Carnasciali dos Santos. Tive a grata satisfação de contar com sua larga experiência tanto na banca de avaliação da Dissertação quanto na Qualificação para a Tese. Suas pontuações, aliadas à prévia leitura de sua produção, enriqueceram amplamente meu olhar acerca do tratamento das questões indigenistas tanto de língua quanto de cultura.

Todavia, no que concerne às especificidades de língua e uso, a pessoa que mais tem trabalhado para esta produção é minha orientadora, a Prof ${ }^{a}$ Dra. Rosane de Sá Amado. Foi ela a primeira pesquisadora a elaborar uma descrição do Gavião. Desse modo, agradeço a Rosane, por sua competência, acolhimento, orientação e espaço para a atuação criativa e autônoma, ao longo de uma década de parceria. E que, espero, não termine por aqui.

Além disso, agradeço à agência de fomento, Capes (Comissão de Aperfeiçoamento de Pessoal de Nível Superior), pela bolsa, que me permitiu dedicação excusiva aos meus estudos pelo período de quatro anos.

No que diz respeito às possibilidades de conhecer as interfaces, que permeiam linguagem e cognição, sou grata pela oportunidade de ter participado do curso ofertado por iniciativa do Prof. Dr. Marcelo Módolo e da Profa ${ }^{a}$. Dra. Maria Célia Hernandes-Lima, em minha unidade de pós-graduação, nos idos de 2013. Além disso, devo agradecer à Prof ${ }^{a}$. Dra. Sara Del Prete Panciera e demais membros do grupo de estudos e pesquisa sobre sociocognição e linguagem, no qual venho atuando há cerca de dois anos, através da Faculdade de Psicologia, da Universidade Federal de São Paulo (Unifesp), na qual curso bacharelado em Psicologia.

Por fim e com enorme carinho, agradeço àqueles que estiveram sempre ao meu lado: meu pai, José Carlos da Silva, pelo apoio e incentivo à carreira acadêmica; minha mãe, Conceição Rodrigues da Silva, por ser uma mulher 
inteligente, corajosa e determinada, que me ensinou a lutar por aquilo que desejamos e necessitamos para mantermos a saúde mental, no meu caso, os estudos; minha irmã, Tayane Rodrigues da Silva, que me diz sobre o lugar de educadora infantil em uma unidade municipal, em um país pouco atento à formação de sua população; e ao meu cunhado, Alex Fernando Santos, por ser uma pessoa muito generosa e solícita, diante das dificuldades desta longa vida. 
Havia aprendido sem esforço o inglês, o francês, o português, o latim. Suspeito, contudo, que não era muito capaz de pensar. Pensar é esquecer diferenças, é generalizar, abstrair. $\mathcal{N} o$ mundo abarrotado de Funes não havia senão detalhes, quase imediatos. (Conto "Funes, o memorioso". Autor: Jorge Luis Borges)

Para desenrolar seus pergaminhos é preciso que eles encontrem temas de dissertação. Existe número infinito de temas, pois pode-se falar sobre tudo e sobre nada. Pilhas de papel amarelado se acumulam nos arquivos que são mais tristes do que cemitérios porque neles não vemos nem mesmo no dia de Finados. A cultura desaparece numa multidão de produções, numa avalanche de sinais, na loucura da quantidade. (A arte do Romance. Autor: Milan Kundera)

Tempo para mim significa a desagregação da matéria. O tempo não existe. O que chamamos de tempo é o movimento de evolução das coisas, mas o tempo em si não existe. $\mathcal{N} a$ eternidade não existe o tempo. (As palavras. Autora: Clarice Lispector) 


\section{Resumo}

No presente estudo buscamos analisar tempo, aspecto e modalidade (COMRIE, 1976, 1985; GIVÓN, 1995; MIRANDA, 2005), no dialeto Timbira conhecido como Pykobjê-Gavião (Tronco Macro-Jê, Família Jê). Inicialmente, discutimos as questões referentes aos pólos da linguística, focando em: (i) pólo formalista, (ii) pólo funcionalista e (iii) cognitivistas. Trouxemos, então, a temática da comunidade de fala, língua e uso(s). Abordamos a perspectiva da educação (FILHO, 2006; PATTO, 1996), refletindo sobre as políticas públicas, que envolvem alfabetização (OLIVEIRA, 2001) e letramento (TFOUNI, 2006), a partir de uma proposta crítica acerca da noção de identidade (RIBEIRO, 2006; RODRIGUES, 2006). Discutimos também o papel da sociocognição e empreendemos um exercício a partir do referencial teórico de Myers-Scotton (2002).

Palavras-chave: Linguística; Timbira; identidade; tempo; aspecto; modo. 


\begin{abstract}
In this thesis, we have analised tense, aspect and modality (COMRIE, 1976, 1985; GIVÓN, 1995; MIRANDA, 2005), in one Timbira's dialect, known as Pykobjê-Gavião (Macro-Jê Branch, Jê Family). Initially, we have discussed the issues about the points of linguistics, focusing on: (i) formalists, (ii) functionalists and (iii) cognitive linguistics. We assumed then the theme of the speech community, language and its use(s). We approach the perspective of education (FILHO, 2006; PATTO, 1996), thinking about the public policy involving literacy (OLIVEIRA, 2001; TFOUNI, 2006), from a critical proposal about the critical perspective of identity (RIBEIRO , 2006; Rodrigues, 2006). We also have discussed about the role of sociocognition and made efforts for the theoretical framework of Myers-Scotton (2002).
\end{abstract}

Keywords: Linguistics; Timbira; identity; tense; aspect; modality. 


\section{Lista de abreviaturas ${ }^{1}$}

$$
1 \text { - primeira pessoa }
$$

1E - primeira pessoa exclusiva (restrito para plural, em contraposição a plural inclusivo)

2 - segunda pessoa

3 - terceira pessoa

A - sujeito de verbo transitivo

A1 - primeiro argumento de predicado

A2 - segundo argumento de predicado

A3 - terceiro argumento de predicado

ADT - conjunção aditiva

ADV - advérbio

AUM - aumentativo

BDT - branching direction theory

BEN - benefactivo

CADV - conjunção adversativa

CAUS - partícula causativa ou de finalidade

COL - coletivo

COMP - partícula de companhia

$$
\text { COP - cópula }
$$

CTI - Centro de Trabalho Indigenista

DAT - dativo

DEM - demonstrativo

DET - determinante

\footnotetext{
1 A marcação de glosas adotada foi baseada nas Leipzig Glossing Rules, desenvolvidas em conjunto pelo Departamento de Linguística do Instituto Max Planck (B. Comrie, M. Haspelmath) e pelo Departamento de Linguística da Universidade de Leipzig (B. Bickel).
} 
DEO - posposição com função deôntica

DI - dativo de interesse

DIM - diminutivo

DIR - diretivo

$E^{\prime}$ - momento do evento

EL - embedded language

ERG - ergativo

EXP - conjunção explicativa

$\mathbf{F}-$ feminino

Funai - Fundação Nacional do Índio

FUT/LEX - futuro por item lexicalizado

GR - grammatical relation

HAB - aspecto imperfectivo habitual

HDT - head-dependent theory

IMP - imperative

INS - instrumental

INTR - intransitivo

IRR - irrealis

LOC - locativo

M - masculino

MEC - Ministério da Educação

$\mathrm{ML}$ - matrix language

MLF - matrix language frame

M.NLU - model of the natural language user

MP - marca de posse

NEG - negativo 
NLU - natural language user

$$
\text { NP - noun frase }
$$

NPr - nome próprio

$\mathbf{P}$ - objeto de verbo transitivo

PAS/LEX - passado por item lexicalizado

PB - Português Brasileiro

PC - partícula complementarizadora

PCN - Parâmetros Curriculares Nacionais

PD - pronome dependente

PE - pronome enfático

PERF - aspecto perfectivo

PF - partícula fonte

PI - pronome independente

$\mathrm{PL}$ - plural

PL/NC - plural não-contável

PROG - aspecto imperfectivo contínuo progressivo

PP/LEX - particípio presente lexical

PT - partícula temporal

QDN - quantificador discreto numeral

QE - quantificador existencial

QI - quantificador indefinido

QU - quantificador universal

REC - recíproco

REFL - reflexivo

S - sujeito de verbo intransitivo

S' - momento do discurso 
SoA - state of affairs

TC - termo de classe

TEA - transtornos do espectro autista

TI - terra indígena

ToM - theory of mind

USP - uniform structure principle

VP - verbal frase

WH - pró-forma interrogativa 


\section{Lista de quadros e imagens}

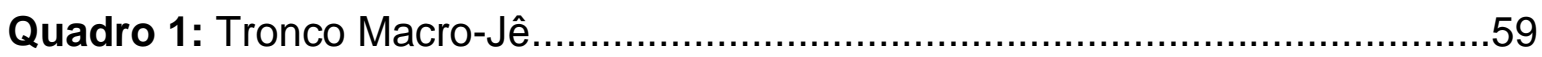

Quadro 2: Consoantes do Pykobjê-Gavião.......................................................113

Quadro 3: Vogais orais do Pykobjê-Gavião...................................................113

Quadro 4: Vogais nasais do Pykobjê-Gavião..................................................114

Quadro 5: Consoantes e vogais fonético-articulatórias do Pykobjê-Gavião.........114

Quadro 6: Pronomes dependentes...........................................................119

Quadro 7: Pronomes independentes..........................................................119

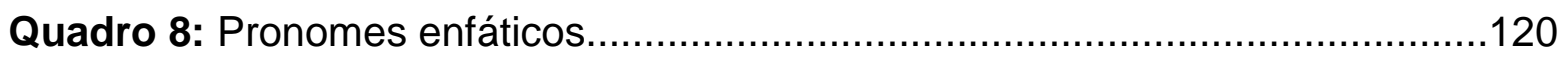

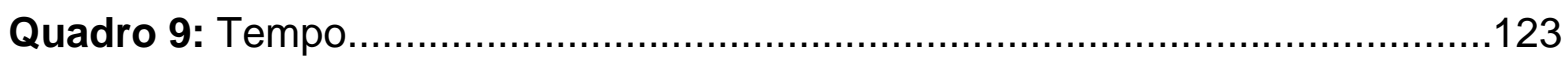

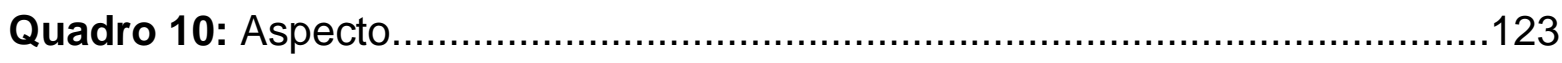

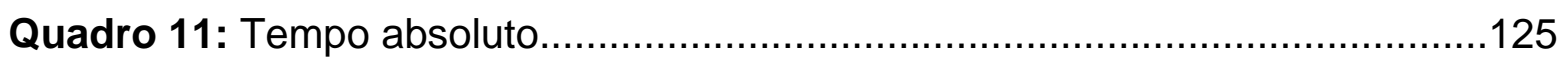

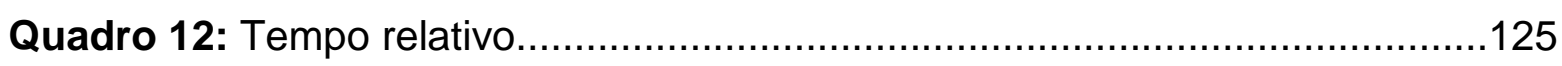

Quadro 13: Categorias de aspecto em Canela................................................151

Grafia uniformizada Timbira (apud AMADO, 2004, p. 158-160)..........................171

Imagem 1: Esquema a partir da linguística sistêmico-funcional...............................36

Imagem 2: Esquema de interação verbal, na visão funcionalista da linguagem..41/80

Imagem 3: Descrição dos estágios do desenvolvimento cognitivo, de Piaget...........88

Imagem 4: Classificação de traços morfológicos, segunda a Teoria dos 4-M..........99

Imagem 5: Bacia hidrográfica do Rio Tocantins..............................................181

Imagem 6: Aldeias Timbira e vizinhas (NIMUENDAJU, 1946)...............................182 


\section{Índice}

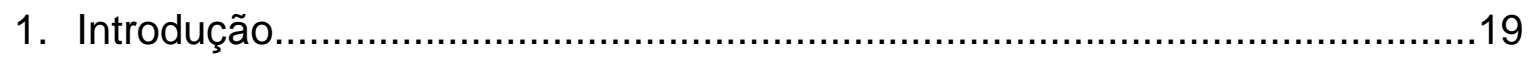

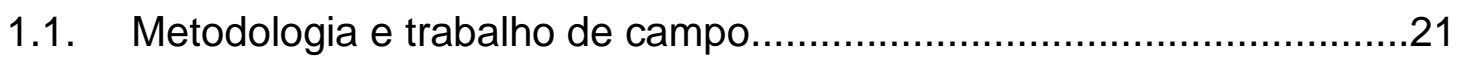

2. Linguística e produção de saber-fazer: os pólos da linguagem......................30

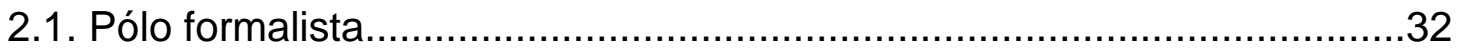

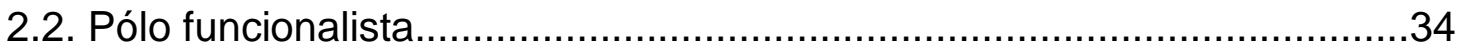

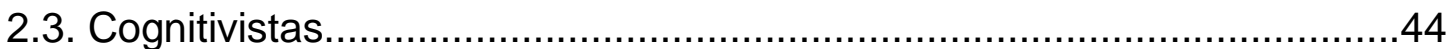

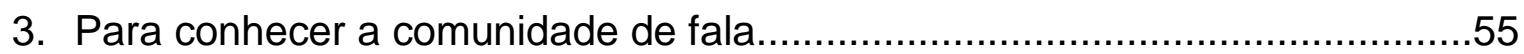

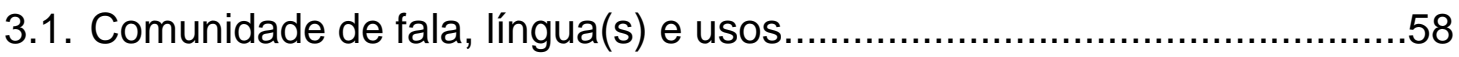

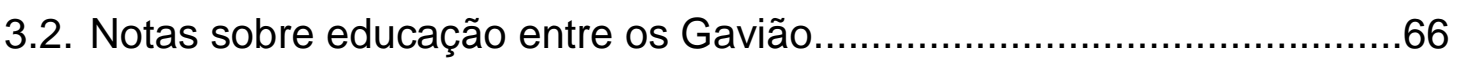

3.3. Alfabetização e letramento: identidades em disputa................................71

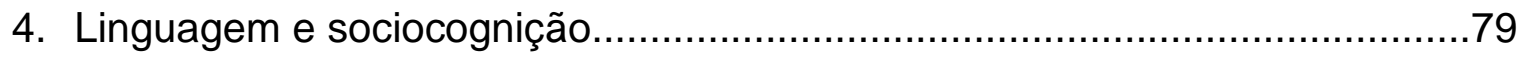

4.1. Considerações sobre PB (L2) e os usos mórficos...................................93

5. Estudos prévios sobre o Pykobjê-Gavião (Timbira)...................................113

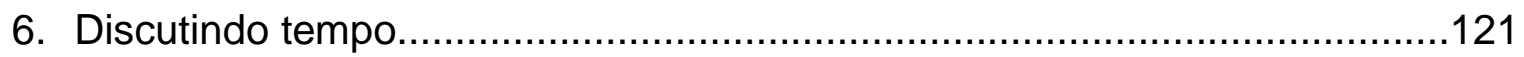

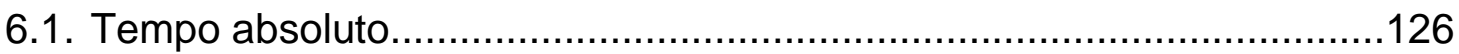

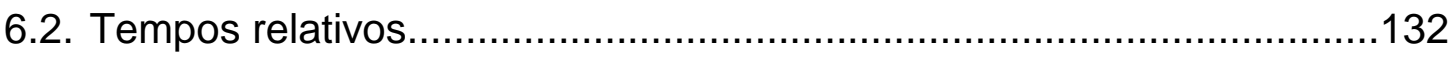

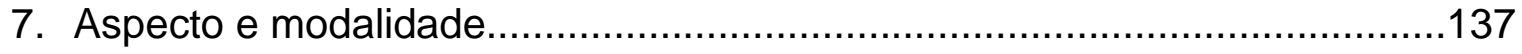

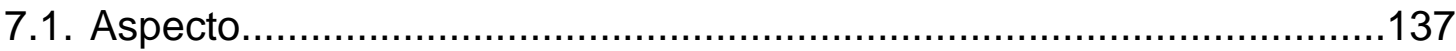

7.1.1. Perfectivo

7.1.2. Pontual, durativo e imperfectivo..........................................139

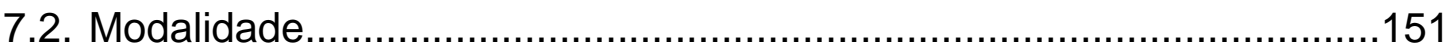

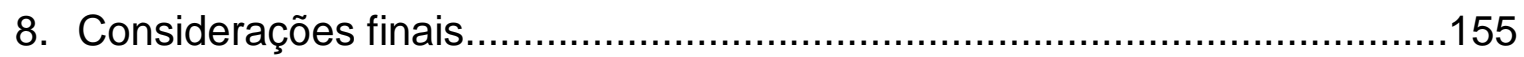

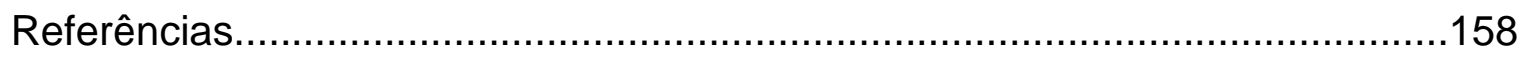

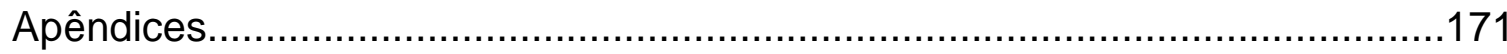




\section{Introdução}

Assumimos como objetivo desenvolver uma descrição e análise sincrônicas, priorizando os enfoques funcionalistas e sociocognitivistas da linguagem sobre tempo, aspecto e modalidade de uma língua indígena brasileira, o Pykobê-Gavião.

Nossa disposição de dados, portanto, está assentada no conteúdo linguístico manifesto e em uso por uma comunidade de fala. Reconhecemos, desde já, que o presente estudo tende a apresentar questões pontuais acerca de um dialeto Timbira (AMADO, 2004; ALVES, 2004, 2008; FERREIRA, 2003; FREITAS, 2008; SILVA, 2012), que vem recebendo empréstimos laterais e heranças verticais passíveis, por sua vez, de uma análise a posteriori. Isso significa declarar que essa pesquisa diz sobre uma faceta de uma variante linguística viva, em uso e, como tal, submetida a fatores extralinguísticos (GIVÓN, 1995).

Para fundamentar nossa pesquisa no âmbito da linguística, discutiremos, no capítulo 2, acerca dos pólos da linguagem: formalismos, funcionalismos e os avanços cognitivistas. Ao fim deste capítulo, propomos, também, uma análise institucional da linguística como campo de poder em disputa (FOUCAULT, 2002), indagando sobre o espaço ocupado/ocupável pela Linguística voltada a línguas subrepresentadas, incluso as indígenas do Brasil.

No capítulo 3, abordaremos a temática da comunidade de fala, língua e uso(s) entre os Pykobjê-Gavião. Então, assumiremos como um dos focos desta pesquisa discutir a perspectiva da Educação (FILHO, 2006; PATTO, 1996), refletindo sobre as políticas públicas, que envolvem alfabetização (OLIVEIRA, 2001) e letramento (TFOUNI, 2006), a partir de uma proposta crítica acerca da noção de identidade (RIBEIRO, 2006; RODRIGUES, 2006).

Mais adiante, no capítulo 4, apresentaremos uma discussão sobre a sociocognição da linguagem, teoria da mente (CAIXETA; CAIXETA, 2005) e seus desdobramentos no campo da linguagem (GIVÓN, 1995). Ao final, faremos um exercício a partir dos pressupostos de Myers-Scotton (2001), em que indagaremos acerca da aquisição do Português do Brasil (PB) como língua não materna (L2) e aquisição de língua escrita, conectando isso ao que discumos no capítulo anterior.

No capítulo 5, faremos uma retomada dos estudos que nos antecedem. Pois entendemos que essa pesquisa dá sequência (dentre outros) ao trabalho 
desenvolvido por Silva (2012), em que foram descritas e analisadas as categorias de palavras do Pykobjê-Gavião, com ênfase em nome e verbo.

No presente desafio, assim, nossa proposta é apresentar as relações que envolvem tempo, aspecto e modalidade (COMRIE, 1976, 1985; GIVÓN, 1995; MIRANDA, 2005), no dialeto Pykobjê-Gavião, privilegiando uma perspectiva morfossintática e morfossemântica, sem desconsiderar a proeminência da pragmática. Além disso, trataremos das distinções entre tempo metalinguístico e tempo de língua (LEVINSON, 2007), de modo a testar como tanto uma instância quanto a outra tendem a se apresentar.

No que se refere à indicação de tempo, discutido no capítulo 6, buscaremos mapear as relações entre significado e implicatura e, então, entre tempo e marcação adverbial, conforme indicado por Comrie (1985, p. 25 e 30), de modo a desmistificar a concepção corrente de que tempo se vincula, necessariamente, à categoria verbal (CORÔA, 2005; ILARI, 2013).

Para discutir como o Pykobjê-Gavião marca tempo, retomaremos, também, os três "pontos temporais", propostos por Reichenbach e discutidos em Comrie (1976, 1985). Ainda com base neste autor, observaremos as possibilidades de marcação de tempo ou aspecto, por meio de: (a) expressões compostas lexicalmente (lexically composite expressions), (b) itens lexicais (lexical items), (c) categorias gramaticais (grammatical categories). E, então, buscaremos descrever a possibilidade que há em cada uma delas para indicar os tempos absolutos (item 6.1.): presente, passado e futuro.

Além disso, discutiremos a interpretação teórica referente a tempos relativos (item 6.2.): tempo relativo puro (COMRIE, 1985, p. 62) e tempo relativo-absoluto (COMRIE, 1985, p. 65). E, então, buscaremos a possibilidade de aplicação em Pykobjê-Gavião, de modo a testar se esta variante apresenta tempos relativos; e, uma vez que isso ocorra, entender como eles são dispostos no enunciado.

No que se refere ao âmbito aspectual, assim como proposto para tempo, averiguaremos se a língua gramaticaliza distinções de aspecto semântico. Se sim, buscaremos entender como o faz e quais são os níveis linguísticos mais mobilizados para essa marcação.

Sobre aspecto, no capítulo 7 (item 7.1.), discutiremos apenas situações dinâmicas, relegando uma reanálise sobre estado a estudos vindouros. Nesse 
contexto, avaliaremos perfectividade (item 7.1.1) e imperfectividade (item 7.1.2), com base em Comrie (1976, p. 16). Sobre perfectividade, buscaremos possíveis distinções entre habitual, em contraponto a contínuo. E, em contínuo, possibilidades de marcação de 'progressivo' e 'não progressivo', sabendo que é comum que determinada língua eleja apenas um dos dois para marcar.

Para realizar essa discussão, recorreremos não somente a Comrie (1976, 1985), mas também às análises dispostas sobre marcação de pluralidade verbal, que levam em consideração as variantes: tempo (ex. 01), espaço (ex. 02) e participante (ex. 03) (CUSIC, 1981; van GEENHOVEN, 2005), conforme apresentamos nos exemplos dados abaixo:

1. Todas as manhãs uma flor diferente desabrocha neste parque.

2. Uma flor desabrocha às 10 horas nos seis diferentes jardins desta cidade.

3. Diversas flores desabrocharam nesta primavera.

Com isso, apresentamos um panorama dos estudos, que desejamos empreender, ao longo desta Tese. Porém, reconhecendo que os dados ocupam um importante espaço na teoria e na prática em Linguística, discorreremos sobre nossa metodologia de trabalho, no item seguinte.

\subsection{Metodologia e trabalho de campo}

Realizamos duas viagens de campo, uma em 2010, nas aldeias Gavião; e outra em 2014, desenvolvida na UFG (Universidade Federal de Goiás) ${ }^{2}$, em que há um programa de Educação Intercultural, voltado a populações indígenas de todo o país. Além disso, viemos testando dados com alguns dos interlocutores, quando era possível o contato pela internet.

Nossa primeira viagem de campo ocorreu em fevereiro de 2010, ocasião em que permanecemos por aproximadamente três semanas (25 de fevereiro a 16 de

\footnotetext{
${ }^{2}$ Para entender melhor como funciona a educação intercultural entre povos indígenas brasileiros, sugerimos a leitura de um texto disponível na Revista da UFG (2006), de autoria de Maria do Socorro Pimentel da Silva em parceria com Leandro Mendes Rocha:

http://www.proec.ufg.br/revista_ufg/dezembro2006/textos/educacao_bilingue.pdf. Acesso: 13/10/2016.
} 
março) em uma das quatro aldeias Gavião, a aldeia Governador, localizada a cerca de 20 km do centro da cidade de Amarante (microrregião de Imperatriz, MA).

A aldeia Governador é a mais antiga e também a mais numerosa (à época de 2011, com 260 indivíduos) dentre as quatro aldeias Gavião ${ }^{3}$ (total populacional na faixa de 600 indivíduos, segundo informações de 2011). Os indígenas de Governador costumam citar o fato de que teria sido esta a aldeia fundadora. De qualquer modo, os indígenas Gavião, independentemente de onde estejam, reconhecem-se como parentes $\left(m e h \tilde{e}^{4}\right)$ e não há grande diferença verificada entre seus falares, modus vivendi ou costumes.

Devido a uma série de contratempos, que culminaram na ocasião da estadia em Terra Indígena (TI), tais como a invasão de madeireiros à aldeia de Rubiácea, a coleta de dados foi possível apenas na aldeia Governador, o que não prejudicou, contudo, nosso contato com a diversidade linguística, uma vez que estivemos brevemente nas demais aldeias Gavião, além de podermos receber a visita dos indígenas das demais aldeias em Governador.

Apesar disso, todos os nossos interlocutores ${ }^{5}$ eram habitantes de Governador, no momento desta estadia.

Em campo, chamou-nos a atenção o fato de que a língua dos "velhos" (entendendo-os por aqueles indivíduos que têm 50 anos ou mais) é, perceptivelmente, mais carregada do sotaque típico dos Pykobjê-Gavião, conhecido como "fala cansada", fenômeno este descrito por Sá (1999).

Os velhos também apresentavam uma produção de Português mais truncada do que a dos jovens. No entanto, o ponto em que observamos a maior discrepância foi no concernente ao emprego de empréstimos advindos do Português do Brasil (doravante PB). Por momentos (durante a coleta de dados), houve discussões entre velhos e demais, porque os jovens não se lembravam de como dado item lexical seria nomeado na fala dos antigos. Contudo, a questão a se fazer é se a palavra citada pelos velhos poderia, de fato, apresentar um significado equiparável no uso àquele designado pela palavra emprestada do PB.

\footnotetext{
${ }^{3}$ As demais aldeias Pykobjê são: Rubiácea, Riachinho e Aldeia Nova.

${ }^{4}$ Literalmente, designaria "minha carne", porém poderia ser entendido como o corriqueiro uso que fazemos da expressão "carne da minha carne".

${ }^{5}$ Utilizaremos, ao longo de todo esse escrito, o termo "interlocutor" e não "informante", por considerarmos que, em um trabalho linguístico, nossos parceiros a fornecerem dados não atuam como "informantes" de uma pesquisa-intervenção clássica, antes seriam "agentes" no processo de percepção linguística, por isso opto pelo uso de "interlocutor".
} 
Como podemos depreender, essa é uma questão muito mais capciosa do que o alcance do presente estudo, já que dispensaria um olhar para os usos dos itens lexicais emprestados do PB. Desse modo, acreditamos que esse tema mereceria ser abordado em momento posterior, por uma análise sociolinguística e que abarcasse levantamentos estatísticos dos usos, analisando, ainda, as influências interpares e intergrupos. Seria necessário, portanto, que o pesquisador dispensasse atenção redobrada às quatro aldeias Gavião (até o momento desta escrita), já que a presença de mais ou menos velhos em cada uma delas poderia resultar em diferenças nos levantamentos dos usos dos vocábulos (predicados, argumentos ou satélites).

Por ora, podemos afirmar, grosso modo, que a incorporação de palavras do PB é mais marcante na fala dos mais jovens do que na dos mais velhos (com destaque para as mulheres). Esse fator externo aponta para uma variação diacrônica em curso (THOMASON; KAUFMANN, 1988), que pode: (a) estagnar-se nas gerações futuras, (b) levar à criação de uma língua mista, em que o PykobjêGavião será a língua matriz e o PB a língua encaixada ou (c) detonar uma mudança de língua, do Pykobjê-Gavião para o PB, que, por sua vez, já atua como língua veicular nessa comunidade de fala.

Em termos quantitativos, apesar de não ter sido feito um levantamento cuidadoso do falar corrente Gavião, pudemos observar (em falas direcionadas a nós, bem como entre os falantes Gavião) que a maior parte das palavras emprestadas do PB atua como conector entre sentenças compostas por verbos absolutos justapostos (ex.: $\max >$ mas).

Uma sentença como "Ontem eu caí mas eu me levantei", por exemplo, poderia ser expressa em Pykobjê-Gavião com $\{\max \}$, como aparece em (4):

4. e'no'ny ẽj-pym max ẽj-xam

PAS/LEX 1PD-cair mas 1PD-levantar"

'Ontem eu caí mas levantei'

Apesar de ser escrito de modo diferente, $\{\max \}$ apresenta a mesma realização fonológica, /mas/, do PB maranhese ${ }^{6}$.

\footnotetext{
${ }^{6}$ Ressaltando que esse item apresenta variações em PB, como a verificada em alguns falares sulistas.
} 
Em termos sintáticos, seu uso também parece muito semelhante ao que é feito em PB. Contudo, ao tomarmos o dialeto Timbira, vemos que é possível usar um conector em igual posição, conforme indicado pelo \{xỳm\}, exemplo (5). Ele marca causalidade. Isso aparece como uma evidência de que, em empréstimo, a sintaxe está subordinada à da língua receptora, no caso, PB fica subordinado ao Gavião:

5. wa j-õnte xỳm j-õnte xwa

1PI PR-dormir pois PR-dormir ter.sono

'Eu dormi pois estava com sono (de dormir ${ }^{7}$ )

Semanticamente, são mais emprestáveis os nomes que designam tecnologias do não índio (cöpẽ) (ex.: gibi - gibi (/3i'bi/)), alimentos industrializados (ex.: arroz aahuj (/a:'huj/)), hábitos não tradicionais (ex.: estudar - etoda (/e’to.de/)) e ambientes da vida na cidade (exs.: hotel - öter (/u:'ter/, hospital - öspitar (/us.pi'tar/), escola - ëcoj (/e'coj/)). E, assim como foi observado no que diz respeito à sintaxe, a maioria dos empréstimos lexicais está acomodada fonética e fonologicamente à língua receptora, o Pykobjê-Gavião.

Retomando as discussões sobre o trabalho de campo, pelo fato de essa recolha almejar alcançar um corpus expoente da linguagem verbal em uso ${ }^{8}$, ao invés de se restringir à obtenção de um conjunto de sentenças, que não passasse pelo crivo da competência linguística, em dadas situações de fala, adotamos uma metodologia específica para a coleta de dados. Ela consistiu em contarmos sempre com a presença de, pelo menos, dois interlocutores, sendo um deles aquilo que denominamos de "consultante fixo" e o(s) outro(s) seria(m) o(s) denominado(s) "consultante(s) variante(s)".

A diferença entre os membros dessas duas categorias concentra-se, unicamente, no grau de domínio da norma escrita adotada para o Pykobjê-Gavião, pois os interlocutores fixos apresentavam mais proficiência no código escrito (grafia missionária) da língua em uso nessa comunidade de fala. Isso foi importante, sobretudo no começo da coleta de dados, porque desconhecíamos a escrita

\footnotetext{
7 "Sono de dormir" contrapõe-se, por exemplo, ao "sono de preguiça" ou "sono de mal-estar".

${ }^{8}$ Reconhecemos e pontuamos, aqui, a grande dificuldade, que permeia o objetivo de buscar olhar para a língua em uso de uma comunidade linguística, da qual não se é parte. Por isso, ressaltamos o desejo de que este trabalho encontre frutos entre os Gavião, de modo que as pesquisas vindouras possam ser realizadas pelos membros desta comunidade de fala.
} 
missionária e desejávamos aprendê-la para facilitar as discussões com nossos interlocutores, que encontraram na escrita um meio adequado de veiculação do conhecimento linguístico para mim, uma cöpẽ ${ }^{9}$. Então, convencionamos gravar e escrever as sentenças previamente elaboradas. Gravar, para que pudéssemos retomar o conteúdo ofertado, em caso de dúvida; e, escrever, para entendermos a quais morfemas os falantes se referem, uma vez que houvesse homofonia, por exemplo. Diante disso, deparamo-nos com um empecilho, ou seja, os interlocutores não conheciam a grafia uniformizada (Apêndice). Ela foi elaborada em 2003, Carolina-MA, com a assessoria de linguistas e falantes, por iniciativa do Centro de Trabalho Indigenista $(\mathrm{CTI})^{10}$. Diante disso, optamos por escrever em grafia missionária, a usada nas aldeias Gavião e Krikati, e, depois, transpormos à grafia uniformizada, já utilizada por nós em trabalhos anteriores (SILVA, 2012)

No entanto, importa ressaltar que em ambos os grupos, 100\% dos interlocutores é falante nativo de Pykobjê-Gavião, nasceu, cresceu e mora em uma das quatro aldeias Gavião. Três dos quatro interlocutores fixos atuavam como professores (pröfisör) na escola indígena da aldeia Gavião, à época da coleta, sendo um deles diretor. Todos os professores, além de ministrarem as aulas que lhes são pertinentes, ainda parecem empenhados em desenvolver materiais didáticos sobre 0 ensino da modalidade escrita do Pykobjê-Gavião, a partir dos referenciais teóricos abordados na UFG. Isso fala sobre a importância prática que significa para este povo o acesso a um Ensino Superior público e de qualidade.

Sobre o grupo dos consultantes variantes, que é mais amplo (cerca de quinze pessoas) e heterogêneo (diversas faixas etárias), ele foi constituído por membros indígenas, que assumiam possuir menor habilidade na escrita ou serem analfabetos. Eles foram muito importantes nas discussões, que enfocaram a competência linguística, uma vez que partimos do pressuposto de que todos os falantes portam uma gramática acerca dos usos de sua(s) língua(s).

A coleta de dados realizada em 2010, no começo, se deu na casa do chefe do posto, onde estivemos hospedados, ou na escola, que foi preferida nos momentos em que estávamos aprendendo a escrita, que os Pykobjê usam e ensinam nos cursos de alfabetização, pois a lousa era, então, indispensável para eles. No entanto, em pouco mais de uma semana, os locais de coleta de dados passaram a

\footnotetext{
${ }^{9}$ Referência a qualquer sujeito que não seja membro do grupo étnico, "branca".

${ }^{10}$ Sobre essa questão, discutiremos mais detidamente no terceiro capítulo.
} 
ser os mais variados possíveis, uma vez que já havíamos internalizado as regras de escrita vigente, o que dispensava a necessidade da lousa da escola.

Então, pudemos usar o gravador digital, para tornarmos a coleta ainda mais dinâmica. Nessa etapa, propúnhamos uma sentença do PB e anotávamos as respostas possíveis. Somente depois do retorno, transcrevemos (para a grafia missionária e desta para uniformizada, de modo a passar pelo crivo da comunidade) as sentenças oferecidas como respostas, conhecendo, algumas das implicações pragmáticas envolvidas em cada sentença.

Apesar de mais trabalhoso, acreditamos que o maior ganho obtido com esse método esteja na capacidade de termos um pouco mais de acesso ao nível pragmático implicado na escolha de uma sentença em detrimento de outra. Isso torna a descrição e a análise, que propomos, um pouco menos cegas às questões que envolvem o contexto de fala. Apesar de todo o cuidado que buscamos tomar, no momento da coleta, assumimos que nossos dados dizem respeito a um recorte da dinâmica dessa variante linguística, atrelada, por sua vez, ao contexto (essencialmente inacessível) de fala, o espaço e os interlocutores em contato, considerando que um contexto de fala nunca poderá ser plenamente retomado, uma vez que envolve duas subjetividades contruídas no e pelo uso. Por essa razão, apresentaremos, ao longo desse trabalho, apenas uma resposta para cada pergunta, sem tecer maiores comentários de nível pragmático ou contexto de fala.

No que se refere à escrita missionária, ela vem sendo transmitida por meio dos materiais didáticos produzidos pelos missionários. Segundo os envolvidos, a comunidade não está satisfeita, por acreditarem que estes materiais estariam muito mais próximos da realidade linguística dos Krikati do que de suas próprias. Por esse motivo, alguns representantes da instituição escolar das aldeias dizem estar empenhados em produzir um material para a alfabetização de crianças e adultos, que seja autônomo do dos Krikati.

Nossa primeira viagem de campo (2010) contou com o apoio da reserva técnica disponibilizada pela Fapesp, ao passo em que a segunda transcorreu, totalmente, com recursos próprios.

Nossa segunda viagem de campo se deu em 2014, novamente com duração de cerca de três semanas (03 a 21 de fevereiro). Nessa ocasião, alguns indígenas 
Timbira estavam na UFG, cursando disciplinas requeridas para formação intercultural em nível superior.

Uma vez que já havíamos tido a experiência de desenvolver uma pesquisa mais ampla com este povo, a Dissertação, optamos por preparar, com antecedência, um roteiro de elicitação acerca dos temas, que gostaríamos de abordar nesta Tese. Isso se mostrou bastante eficiente, por economizar tempo, o que não nos era ofertado tão amplamente como no período em que estivemos na aldeia.

Nesta etapa, encontramos alguns dos nossos antigos interlocutores, novamente dispostos a auxiliar. Além disso, contamos com o apoio de uma professora, que, em ocasião de nossa primeira visita, morava em Riachinho; e, de um indígena, que vive em Rubiácea. E, apesar do esforço coletivo, tivemos o prazer de ter interlocução constante com um falante bastante atento aos níveis linguísticos de sua língua materna, que esteve presente na maior parte do tempo de coleta. ${ }^{11}$

Começamos nossa coleta retomando as sentenças simples, para verificar os tempos absolutos. Passeamos por sentenças que poderiam indicar pluralidade, testando os usos de algumas palavras com sentido aspectual, como \{ry'hy\}, exemplo 06, e \{cormỹ , exemplos 07 e 08 . Retomamos os usos de sentenças predicativas e, por fim, tratamos de coordenadas e relativas. Dentre as relativas, detivemos maior atenção às relativas com oração restritiva.

6. cë ry'hy cwyr cor - 're

3PI PERF mandioca comer-DEO

'Ela já comeu a mandioca'

Literalmente: 'Ela precisa comer a mandioca'

7. wa cormy te cöte wyr

$1 \mathrm{PI}$ ASC ir riacho DIR

Interpretação 1-) 'Eu estou indo ao riacho'.

Contexto possível: Caminhando rumo ao riacho, ainda na estrada.

8. wa cormy te cöte wyr

1PI ASC ir riacho DIR

'Acabei de ir ao riacho'

Interpretação 2-) 'Acabei de ir ao riacho'.

Contexto possível: $O$ falante chegou há pouco tempo do riacho em questão.

\footnotetext{
${ }^{11}$ Optamos por resguardar a identidade de nossos interlocutores.
} 
Assim, terminamos nossa breve discussão sobre as dificuldades que dizem respeito à coleta de dados. Gostaríamos de pontuar que houve, sim, momentos difíceis de estar no campo. Porém, entendemos que eles se colocaram como uma resposta à nossa incapacidade para compreender as demandas sociais e culturais deste povo.

Ladeira $(2001,311)$ afirma, por exemplo, que devemos dar atenção especial ao que significa "compreender" nos grupos Timbira. A autora ressalta que, para esses povos indígenas, "o termo usado na língua para escutar e compreender é o mesmo: hapac." Isso ocorre porque, na percepção desses povos, o entendimento da palavra escrita perpassa a sonorização da mesma. Ou seja, entender aquilo que está no papel é também saber decodificar o signo visual (táctil, para deficientes visuais) em signo sonoro. Desse modo, em campo, percebemos a importância de sonorizar as sentenças de elicitação, marcando bem as pausas e fazendo uso de termos conhecidos, tanto lexemáticos quanto gramáticos.

Por exemplo, para elicitar os futuros do PB, percebemos que não funcionavam os usos do futuro simples, como 'amaremos' e 'amaríamos', uma vez que, ao sonorizarem essas formas, elas não eram reconhecidas, porque o dialeto PB dos interlocutores privilegia o uso de auxiliares, que, por sua vez, carregam a informação de tempo e aspecto. Como consequência, havia um ruído que travava o prosseguimento da elicitação, até que pudemos compreender o entrave e propor alterações.

Como ensinamento, entendemos que, para partilhar desse fazer linguístico grupal, julgamos essencial que o profissional teórico seja também o que desenvolve o trabalho de campo, porque é lá que a língua emerge como potência e, então, aprendemos sobre suas limitações, o que é imprescindível ao amadurecimento técnico e teórico.

Nessa linha de observação, Duranti (2001) declara que um linguista deveria ter uma formação antropológica, tal que pudesse atuar como um antropólogo linguístico, um linguista antropológico ou um etnolinguista... De todo modo, esse profissional seria instigado, desde sua formação inicial, a estar atento e remarcar em seus estudos tudo aquilo que circunda a língua:

Questões e espaços de perguntas e respostas feitas pelo pesquisador de campo são frequentemente deixados de lado nas transcrições, bem como o 
são outros traços de interação (ex.: pausas, falsos começos) que não parecem relevantes ao estudo dos traços fonológicos (ex.: apagamento da consoante final). No mais, alguns desses traços são considerados importantes pelos antropólogos linguistas e outros pesquisadores que acreditam na co-construção dos relatos narrativos e na importância do monitoramento mútuo que ocorre em qualquer encontro. ${ }^{12}$ (DURANTI, 2001, p. 07, tradução nossa)

Com as palavras de Duranti (2001) ecoando, passamos ao capítulo seguinte, no qual trataremos sobre os pólos da linguística e buscaremos empreender uma breve análise institucional acerca das disputas de poder, neste campo do conhecimento humano.

${ }^{12}$ Texto original: "Questions and feedback channel responses by fieldworkers are often left out of transcripts together with other features of the interaction (e.g. pauses, false starts) that do not seem relevant to the study of phonological features (e.g. deletion of final consonant). And yet, some of these features are considered important by linguistic anthropologists and other researchers who believe in the co-construction of narrative accounts and the importance of the mutual monitoring that goes on in any encounter." 


\title{
2. Linguística e produção de saber-fazer: os pólos da linguagem
}

\begin{abstract}
A análise enunciativa é, pois, uma análise histórica, mas que se mantém fora de qualquer interpretação: às coisas ditas, não se pergunta o que escondem, o que nelas estava dito e o não-dito que involuntariamente recobrem, a abundância de pensamentos, imagens ou fantasmas que as habitam; mas, ao contrário, de que modo existem, o que significa para elas o fato de se terem manifestado, de terem deixado rastros e, talvez, de permanecerem para uma reutilização eventual; o que é para elas o fato de terem aparecido - e nenhuma outra em seu lugar. Desse ponto de vista, não se reconhece nenhum enunciado latente: pois aquilo a que nos dirigimos está na evidência da linguagem efetiva. (FOUCAULT, 2002, p. 124)
\end{abstract}

A linguística aponta a um campo epistemológico que, assim como qualquer outro, é investido de afetos, enquadramentos éticos e projetos político-pedagógicos. Esta ciência, portanto, é um produto sócio-histórico, inventado e biopoliticamente orientado, de modo que trabalhar sob sua perspectiva demanda "se interrogar sobre a vontade de poder que a pretensão de ser uma ciência traz consigo" (FOUCAULT, 2000 , p. 15). E mais, quais são a identidade e o lugar de saber-fazer, que reserva aos que aderem a este tipo de discurso científico.

Desse modo, os saberes linguísticos estão assentados sobre aquilo que Silva (2006) denomina como sendo a "tragédia da ciência pura", em referência à epistemologia, trazida ao campo público de discussão, a partir da organização do Curso de Linguística Geral:

\footnotetext{
A tragédia saussuriana é, em sua mais acabada manifestação, o drama de um herói que luta ardentemente para fundar a pura ciência da linguagem, mas que, por fim, ou desliza em direção à monstruosidade, ou reencontra 0 paradoxo no fulcro de sua criação. (SILVA, 2006, p. 34)
}

Silva (2006) está discutindo, portanto, que o mito criador da linguística, ainda que traga como premissa a autonomia dos objetos de análise, deixa encoberto uma questão mais ampla, que por ser negada como alcance desta ciência é atualizada no campo imaginário. Esta questão é a de que a linguagem atua como potência. Sobre isso, Saussure (2004) afirma:

Mas o que é a língua? Para nós, ela não se confunde com a linguagem; é somente uma parte determinada, essencial dela, indubitavelmente. (...) Tomada em seu todo, a linguagem é multiforme e heteróclita; o cavalheiro de diferentes domínios, ao mesmo tempo física, fisiológica e psíquica, ela pertence além disso ao domínio individual e ao domínio social; não se deixa 
classificar em nenhuma categoria de fatos humanos, pois não se saber como inferir sua unidade. (SAUSSURE, 2004, p. 17)

Quando imprimimos um recorte, estamos mostrando os pontos não privilegiados e estes, por sua vez, dizem respeito ao enquadramento de ciência que demandamos.

A linguística, como outros construtos do século XIX, também busca, em seu caminho de independência epistemológica, encontrar uma causa formal com a qual se aliar. E, conforme vimos acima, as apostas foram nos estudos de língua em detrimento dos de linguagem, uma vez que esta já estava cooptada por áreas afins, como Filosofia, Antropologia, Sociologia e, até mesmo, a recente Psicologia Social.

Sobre a necessidade de alienação de determinados pontos do discurso para se fundar a ciência como um contraponto necessário ao senso comum, Santos (2010) explica:

\begin{abstract}
Aristóteles distingue quatro tipos de causa: a causa material, a causa formal, a causa eficiente e a causa final. As leis da ciência moderna são um tipo de causa formal que privilegia o como funciona das coisas em detrimento de qual o agente ou qual o fim das coisas. É por esta via que o conhecimento científico rompe com o conhecimento do senso comum. (SANTOS, 2010, p. 51)
\end{abstract}

Desse modo, a linguística gerou a demanda de estudar como funciona a língua, retirando deste objeto tudo que pudesse atrapalhar sua visão estruturalmente ordenada. Não seria mais uma questão, por exemplo, analisar o corpo que produz a fala, quem fala, a quem fala e por que fala, ou seja, os agentes e fins do ato de produção verbal. Além disso, "exclui-se a própria idéia de uma determinação exterior do signo, pois considerá-la é já começar a contar uma história que só termina de fato com um mito de origem da linguagem" (LOPES DA SILVA, 2001, p. 298). E, por sua vez, pensar a origem da linguagem significa elaborar teorias sobre a origem (ou origens) do homem que fala, o que não era interessante no momento de compor um novo campo científico.

Contudo, há a proposição de um objeto de domínio, a que se passa a denominar linguagem. Conforme Rajagopalan (2006, p. 79) explica, ao considerar tal recorte no modelo de investigação, "a linguística cria o próprio objeto que, depois, decidiram chamar de a linguagem". 
A linguagem da linguística, como produto de um processo social e historicamente datado, é necessariamente diferente da entendida por outros campos epistomólogicos e por leigos. Como quem busca reconhecer as partes de um elefante branco, que se esconde em um quarto escuro ${ }^{13}$, a linguística fragmenta seu olhar. E, assim, surgem distintos núcleos de pesquisa e atuação.

Conforme ressaltado por Kenedy; Martelotta (2003), podemos pensar, grosso modo, em três pólos: escolas formalistas, escolas funcionalistas e cognitivistas.

\subsection{Pólo formalista}

Para os formalistas, a língua deve ser entendida como um objeto autônomo, passível de ser afastado de outros elementos, remontando, portanto, a uma visão positivista do fenômeno.

Givón (2012) expõe que isso se deveria à emulação direta com as ciências físicas, nas quais é comum, por exemplo, a prática de se isolar os elementos de análise. Desse modo, não causa estranhamento à comunidade científica (ou leiga) que um químico separe determinada partícula, a fim de estudá-la, ou que um físico analise apenas um vetor de força, em uma situação de queda-livre. Além disso, aponta a importante influência que tiveram os estudos da corrente behaviorista da Psicologia ${ }^{14}$.

Dado o contexto exposto acima, Givón (2012) afirma ser possível delimitar três características centrais para a execução dos estudos estruturalistas:

(a) produção de um banco de dados arbitrário, isto é, com listas coletadas sem considerar os diferentes contextos de uso ou sem que o linguista esteja implicado neles;

(b) envolvimento teórico na concepção dos esquemas de formalismo, desvinculando-o da prática linguística relacionada às comunidades de fala e suas identidades;

\footnotetext{
${ }^{13}$ Givón (2012, p. 11) apresenta a metáfora da linguagem como sendo ela um "centro ilusório".

${ }^{14}$ Um nome importante do behaviorismo radical é Burrhus Frederic Skinner (1904-1990). Este autor produziu uma série de experimentos e escritos, que originou uma linha descrita pelo próprio como uma área da Filosofia. Dentre suas produções, podemos citar o famoso livro denominado Verbal Behavior (1957), no qual o autor explica que a relação entre falante e ouvinte seria um tipo de comportamento operante, modulado pela modalidade verbal de estímulos. Além disso, esclarece que os pensamentos nada mais seriam do que comportamentos encobertos. Para saber mais sobre este e outros autores da mesma linha teórica, sugerimos Moreira; Medeiros (2007).
} 
(c) "negligência ou desvalorização da noção explicação" (GIVÓN, 2012, p. 15), pois a explicação seria dada de antemão à confrontação com os dados, respondendo a regras cujas exceções denotariam uma falha do linguista em reconhecer a teoria formalista, tal qual previsto em (b).

Além disso, Givón (2012) explica que a corrente gerativo-transformacional ${ }^{15}$ teria se apoiado nas mesmas bases teóricas estruturalistas, inclusive aprofundandoas, de modo a assumir que:

1. o formalismo é uma teoria;

2. uma teoria que não faz referência aos parâmetros explanatórios naturais da linguagem é, de algum modo, dotada de poderes explanatórios;

3. a medida de simplicidade interna ao formalismo, uma entidade puramente formal sem relação com os parâmetros explanatórios da linguagem, é, de algum modo, a origem da adequação explanatória das gramáticas ou da teoria. (GIVÓN, 2012, p. 21)

Assim, a proposta gerativo-transformacional se apóia na busca daquilo que foi conceitualizado como a "sobrevivência do mais adequado" e, então, aborda como um dos conceitos centrais a emergência da hipótese de "autonomia da sintaxe".

Em termos de aproximação, Chomsky rompe com o behaviorismo radical, ao criticar Verbal behavior (1957) e seus pressupostos. Segundo Chomsky (2008), portanto, a aquisição de uma língua não poderia ser explicada apenas por aprendizagem via estímulo-resposta, antes o seria mais adequado pensar em "processos de maturação internos, ou por causa de experiência externa" (CHOMSKY, 2008, p. 21).

O autor entende também que aquilo que denomina como faculdade da linguagem seria restrita à espécie humana, por isso biologicamente determinada e passível de ser isolada, tal como ocorre com o córtex visual. Sobre a filogenia como fator restritivo, afirmou:

Mas quando se trata de organismos em relação aos quais há uma significativa origem evolutiva comum - os primatas, digamos -, não há nada que tenha similaridades relevantes, o que significa que a faculdade da linguagem, de um modo curioso e inesperado, parece ser biologicamente isolada. (CHOMSKY, 2008, p. 19)

\footnotetext{
${ }^{15}$ Mantemos a nomenclatura proposta por Givón (2012), contudo reconhecemos seus limites de explanação.
} 
Assim, a aposta da corrente gerativo-transformacional abarca um olhar acerca da cognição, que é modular e restrito a um lugar específico da evolução, a chegada ao homem (KENEDY; MARTELOTTA, 2003).

\subsection{Pólo funcionalista}

O funcionalismo é uma abordagem teórica bastante antiga. No século V a.C., na cidade de Atenas, o filósofo Sócrates já apresentava a necessidade de entender o homem e sua linguagem não como unidades isoladas, mas em contínua relação com seus semelhantes, bem como com o Estado. Isso significa interpretar que a linguagem é mais um atributo dentre outros, que marcam a relação do homem com seus sistemas simbólicos e imaginários, dentre eles a constituição da noção de identidade.

No campo da linguística, observa-se que o funcionalismo antecede os estudos saussurianos, com autores como Whitney, Hermann Paul e von der Gabelentz (DeLANCEY, 2001).

Para Hermann Paul (1966), por exemplo, a língua, assim como todos os resultados da produção da cultura humana, constitui um objeto dentre outros da ciência histórica. Esta, por sua vez, difere das ciências naturais exatas, ao assumir a noção da evolução humana e do tempo. Então, o autor divide as ciências históricas em dois grupos: ciências naturais históricas e ciências culturais históricas.

As ciências culturais históricas são aquelas que designam a história da evolução dos instintos artísticos e da organização social dos seres humanos, "é o factor mais essencial de todo o movimento cultural, em torno do qual se move" (PAUL, 1966, p. 14). Por conta disso, o autor entende a Psicologia como uma ciência privilegiada para esse saber-fazer. Todavia, o entendimento de Psicologia que o autor enfatiza está mais próximo daquilo que, adiante, outros teóricos passaram a designar como desenvolvimento ontogenético.

O funcionalismo também encontra respaldo em diversas produções das ciências humanas, conforme atualmente são designados tais campos.

Neves (2004, p. 58) afirma que a gramática funcional de Halliday, por exemplo, dialoga profundamente com as correntes etnográficas de Malinowski e da linguística firthiana da tradição etnográfica de Boas e Sapir-Whorf. 
Desse modo, apesar das diferenças, os vários grupos que se identificam com a proposta funcionalista partilham, dentre outras coisas, o objetivo de analisar as estruturas linguísticas sem separar o sistema linguístico de seu uso, ao contrário do que propunha o mestre estruturalista, Saussure (langue X parole), de acordo com a organização realizada por seus discípulos e publicada como Curso de linguística geral.

As perspectivas funcionalistas partem, desse modo, do seguinte paradigma para entender seu objeto de estudo, isto é, a linguagem natural humana:

A linguagem é vista como uma ferramenta cuja forma se adapta às funções que exerce e, desse modo, ela pode ser explicada somente com base nessas funções, que são, em última análise, comunicativas. (PEZATTI, 2009, p. 168)

Ao traçar um paralelo com a proposta do Curso de linguística geral (2004), podemos dizer que, nos enfoques funcionalistas, não só langue não se separa de parole, mas, ainda, langue está subordinada a parole. Desse modo, a gramática funcional trabalha com a hipótese de que a língua é composta por sistemas de regras estruturadas, que estão subordinadas, por sua vez, às atividades da convenção social. Assim, podemos assumir que a língua natural é, essencialmente, estruturada e cooperativa.

Então, uma boa forma de sintetizar o pensamento central, que molda as teorias funcionalistas, seria mencionar como se obtém a comunicação linguística em uma determinada língua. Isto é, buscar verificar os modos utilizados para que os usuários da língua se comuniquem eficientemente. Retomando Neves (2004):

\footnotetext{
Qualquer abordagem funcionalista de uma língua natural, na verdade, tem como questão básica de interesse a verificação de como se obtém a comunicação com essa língua, isto é, a verificação do modo como os usuários da língua se comunicam eficientemente. (NEVES, 2004, p. 02)
}

Os funcionalistas preocupam-se com um tratamento funcional da organização interna da linguagem, dando destaque a parâmetros como a relação entre cognição e comunicação, processamento mental, aquisição da linguagem, interação social e cultural, evolução e mudança linguística. Nessa concepção de linguagem, defendida pela Escola de Praga, a língua é entendida como um sistema dinâmico. 
Michael Halliday, da escola britânica de John Rupert Firth, então, busca a natureza do sistema linguístico e insiste na existência de funções externas e internas, que permitem a organização sintagmática ou paradigmática de determinada língua. A pluralidade funcional, então, constrói-se na estrutura linguística, que forma a base da língua por meio dos itens lexicais, conhecimentos gramaticais, organizações sintáticas e semânticas, até o usuário chegar ao nível do discurso. Para Halliday, a linguagem serve à expressão do conteúdo, valorizando a função ideacional, que se entende como seu significado cognitivo. Sobre isso, Neves (2004) esclarece:

Todas as línguas são organizadas em torno de dois significados principais: o "ideacional", ou reflexivo, e o "interpessoal", ou ativo. Esses componentes, as metafunções da teoria de Halliday, são as manifestações, no sistema linguístico, dos dois propósitos mais gerais que fundamentam todos os usos da linguagem: entender o ambiente (ideacional) e influir sobre os outros (interpessoal). Associado a esses, o terceiro componente metafuncional, o "textual", Ihes confere relevância. (NEVES, 2004, p. 62)

A fim de visualizarmos, de forma bastante resumida ${ }^{16}$, a proposta de Halliday, colocamos abaixo um esquema proposto por Menéndez (2010):

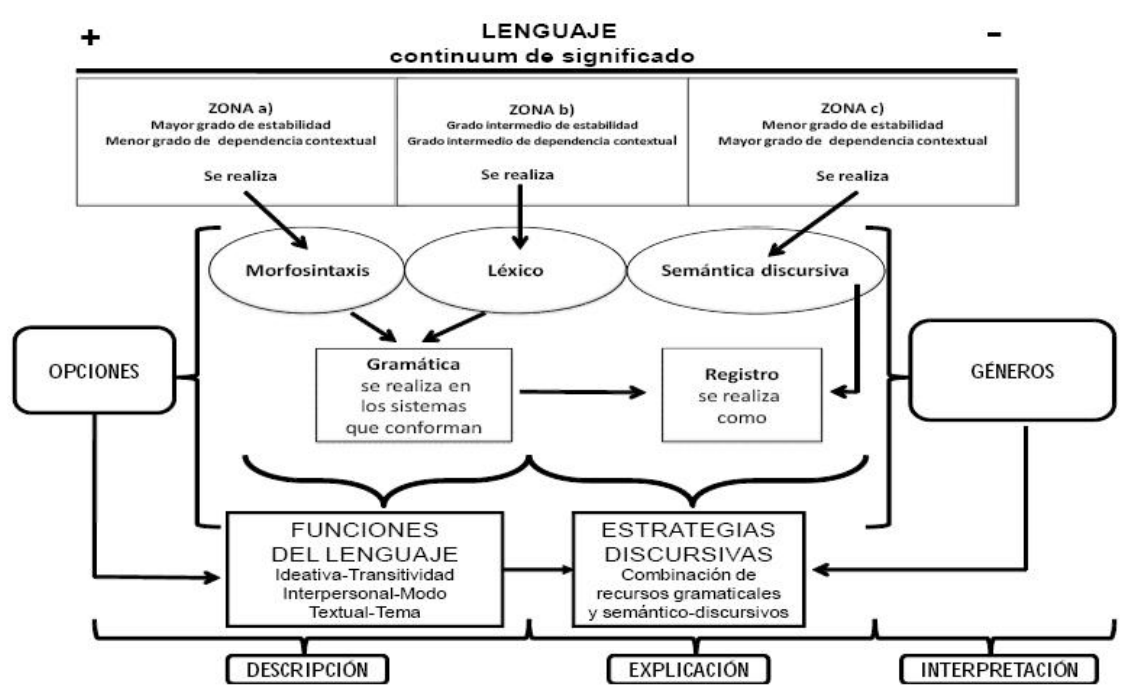

Linguística sistêmico-funcional, de Halliday (retirado de Menéndez, 2010, s/p.)

\footnotetext{
${ }^{16}$ Downes (1998, p. 313) apresenta um esquema bastante amplo acerca das propostas de Halliday, apontando a linguagem como semiótica social ("language as social semiotic"). Ali, mostra que o sistema social é retroalimentado, dinamicamente, pelos tipos situacionais e as funções da linguagem, que geram o texto. O texto, por sua vez, é entendido como "a unidade operacional da língua" (the operational unit of language), segundo Downes (1998, p. 314).
} 
Dik, outro importante funcionalista, pode ser entendido como vinculado à concepção teleológica da linguagem ${ }^{17}$. Retomando a discussão disposta no início deste capítulo, este autor não assume a alienação através de uma causa formal de seu objeto de estudo. Defende que a língua pode ser encarada como um instrumento de interação verbal, uma vez que ela é concebida, em primeiro lugar, como um mecanismo de interação social entre os seres humanos, tendo como objetivo principal estabelecer relações comunicativas.

Dik marca a importância central da relação entre a informação pragmática do falante e a do destinatário. Desse modo, após a codificação estabelecida, o falante manifestaria a intenção do conteúdo da expressão verbal ao destinatário e este, por sua vez, faria uma nova interpretação do conteúdo, a fim de responder o falante para, então, acordarem entendimentos. Porém, do ponto de vista do destinatário, a interpretação será apenas em parte baseada na informação contida na expressão linguística.

Ao tratar da importância de Dik para o pólo funcionalista da linguagem, Neves (2004) afirma que este autor conseguiu integrar eficientemente às competências gramaticais os vários subsistemas que interessam aos funcionalistas:

\begin{abstract}
Desse modo, nas palavras de Dik, a linguística tem de ocupar-se de dois tipos de sistemas de regras, as regras semânticas, sintáticas, morfológicas e fonológicas (que governam a constituição das expressões linguísticas) e as regras pragmáticas (que governam os padrões de interação verbal em que essas expressões linguísticas são usadas). (NEVES, 2004, p. 21)
\end{abstract}

Para entendermos melhor a relação que Dik estabelece entre esses nichos analisados separadamente nos estudos tradicionais de língua (incluso as gramáticas para amplo público), torna-se relevante considerar que, em sua obra, a ideia de sintaxe autônoma, aceita na tradição gerativo-transformacional, é rejeitada. Nas palavras do autor:

A semântica é considerada como fundamental no que diz respeito à pragmática, e a sintaxe como instrumental em relação à semântica. Nesta visão não há espaço para algo como uma "sintaxe autônoma". Ao contrário, na medida em que uma divisão clara e ampla pode ser feita entre sintaxe e semântica, a sintaxe está aí para que as pessoas sejam capazes de formar expressões complexas e com significados complexos, tais significados

\footnotetext{
${ }^{17}$ A visão teleológica da linguagem emula, diretamente, com os pressupostos fillosóficos de Aristóteles e Hegel, ao assumir que é possível depreender metas, objetivos e finalidades a partir de um ente estruturado pela percepção da natureza humana e da vivência social, sendo estas passíveis de atingirem a transcendência.
} 
estão lá, por sua vez, para que as pessoas sejam capazes de se comunicar de diferentes e sutis maneiras. ${ }^{18}$ (DIK, 1997a, p. 08, tradução nossa)

É nesse sentido que Dik representa uma retomada de alguns dos propósitos estruturalistas e de alguns dos objetivos formalistas. Todavia, este autor aparta-se de tais concepções, ao levar em consideração a noção de "competência comunicativa" (HYMES, 1972), ao invés da ideia de "competência gramatical" (CHOMSKY, 1981), por assumir que nem todas as construções que "ferem" as regras gramaticais são infrutíferas e/ou incompreensíveis ao uso dos falantes nativos.

Pensando em uma orientação metodológica aliada a esse modelo, verificamos que, oposto às representações arbóreas, Dik (1997) propõe que, para a constituição de uma gramática funcional, o linguista deve tentar organizar e descrever a competência comunicativa com que um "usuário de língua natural" (NLU) trabalha; logo, deve buscar elaborar um "modelo de usuário de língua natural" (M.NLU). Esse modelo precisa se adequar ao que 0 binômio performance/competência ${ }^{19}$ comunicativa humana explora, isto é, adequação pragmática, brevemente discutida acima e considerada como a de maior peso no uso, adequação tipológica e adequação psicológica.

A adequação tipológica é a que mais se afasta das demais, apesar disso interessa a qualquer teoria linguística. Entende-se que o M.NLU deve ser capaz de explicar o que há em comum e o que difere entre os sistemas linguísticos das línguas humanas naturais, levando em consideração fatores como a difusão areal. Nas palavras de Dik (1997a), a adequação tipológica:

[...] deveria ser capaz de fornecer gramáticas para línguas de qualquer tipo $\mathrm{e}$, ao mesmo tempo, estabelecer de maneira sistemática as semelhanças e as diferenças existentes entre essas línguas. ${ }^{20}$ (DIK, 1997, p. 14, tradução nossa)

\footnotetext{
18 Texto original: "Semantics is regarded as instrumental with respect to pragmatics, and sintax as instrumental with respect to semantics. In this view there is no room for something like an "autonomous" syntax. On the contrary, to the extent that a clear division can be made between syntax and semantics at all, syntax is there for people to be able to form complex expressions for conveying complex meanings, and such meanings are there for people to be able to communicate in the subtle and differentiated ways." 19 O enfoque funcionalista, grosso modo, não distingue "performance" de "competência", como o faz a gramática gerativa chomskyana.

${ }^{20}$ Texto original: "[...] that it should be capable of providing grammars for languages of any type, while at the same time accounting in a systematic way for similarities and differences between these languages."
} 
Nesta Tese, consideramos a importância da adequação tipológica (LEHMANN, 1981), por isso nos propomos ao breve exercício de relacionar as estruturas de análise a outros estudos em Timbira, sobretudo Alves (2004, 2008), que discutiu esta questão em Canela-Apãniekrá, além de Ferreira (2003) e Freitas (2008), que se debruçaram no Gavião-Parkatêjê.

Por fim, devemos considerar as adequações psicológicas, que buscam dar conta, basicamente, dos "modos de compreensão" e dos "modos de produção" nos diversos usos linguísticos. Em Dik (1997a), encontramos a seguinte explicação sobre esses dois funcionamentos:

Os modos de produção definem como os falantes atuam para construir e formular expressões linguísticas; os modos de compreensão especificam como os ouvintes atuam para processar e interpretar expressões linguísticas. ${ }^{21}$ (DIK, 1997, p. 13, tradução nossa)

Podemos dizer, então, que a gramática funcional propõe que olhemos para a linguagem como um mecanismo difundido socialmente, a partir dos elementos culturais disponíveis, de modo a cumprir parte das necessidades comunicativas da espécie humana, homo sapiens sapiens. Por isso, o M.NLU deve prever e dar conta das três adequações discutidas acima:

(a) pragmática, a mais importante por estar vinculada ao uso previsto e acordado tanto previamente quanto no momento da fala entre os membros de determinada língua e cultura;

(b) psicológica, atada à pragmática para dar conta da relação produção/compreensão, sendo biologicamente dependente, mas não resumível ao corpo;

(c) tipológica, que está vinculada à percepção de difusão linguística como prática depreensível em um tempo e espaço.

Para explicitarmos como a adequação psicológica está submetida à pragmática - e esta, por sua vez, controla semântica e sintaxe -, tomemos a fala de Pinker (2004, p. 61): "A Semântica Geral atribui a loucura humana ao "dano semântico" que a estrutura da linguagem provoca no pensamento."

\footnotetext{
${ }^{21}$ Texto original: "Production models define how Ss go about constructing and formulating linguistic expressions; comprehension models specify how As go about processing and interpreting linguistic expressions." O autor usa S como abreviatura para Speaker (falante) e A para Addresser (remetente ou ouvinte):
} 
O autor critica, no trecho destacado, que a semântica guarde referência íntima com a pragmática e rejeita, portanto, movimentos reformistas da linguagem. Um exemplo válido do PB seria o uso difundido de $\{e\}$ em lugar dos morfemas de gênero. Por exemplo, em um contexto de discurso voltado a um público amplo (ou seja, em que estão presentes representantes de ambos os gêneros), ao invés de dizer:

Bom dia a todos!

Poder-se-ia declarar ao público:

Bom dia a todes!

Essa proposta de modificação buscaria minimizar o sexismo embutido em nosso falar ordinário, em anuência com a teoria queer de linguagem (BUTLER, 2003), que, por sua vez, dialoga com o filósofo que desenvolveu a teoria dos atos de fala, John Langshaw Austin (1911-1960), e o historiador crítico da modernidade, Michael Foucault (1926-1984).

Para Pinker (2004), vinculado ao gerativismo chomskiano, essa mudança morfossemântica não alteraria a pragmática, e isso explicaria por que as reformas propostas não seguiram adiante. Já um funcionalista, ele poderia dizer que a semântica se mantém intacta porque a pragmática assim o requer. Retomando o caso da disputa reformista, vinculado à proposta queer de linguagem, o uso de $\{e\}$ só seria aceito como morfema genérico de gênero do $\mathrm{PB}$, se passasse pelo crivo da adequação pragmática, relacionada, por sua vez, às experiências (sexistas) de uso.

Mas, uma vez tendo sido aprovada pela pragmática, também haveria uma adequação psicológica. Isso se explica, na visão funcionalista, porque a língua é tomada como um instrumento de interação social, que tanto se alimenta das experiências de uso quanto fornece dados para novos usuários.

Para resumir o papel da expressão linguística como veículo e veiculador comunicativo, apresentamos uma imagem disponível em Dik (1989a, p. 8-9, apud NEVES, 2004, p. 19), que representa o esquema de interação verbal, na visão funcionalista da linguagem: 


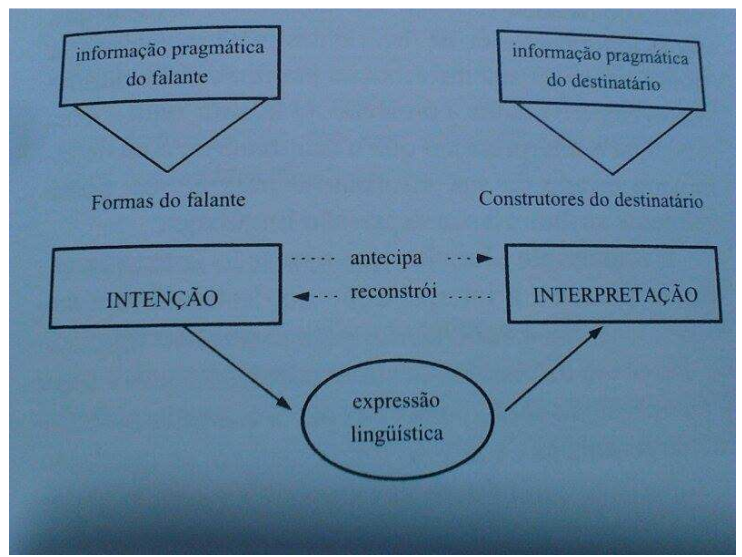

Modelo de interação verbal, de Dik (DIK, 1989ª , p. 8-9, apud NEVES, 2004, p. 19)

O que o esquema busca demonstrar é que falante e destinatário são papéis interacionais, em que há a troca de informações pragmáticas.

Como tanto o falante quanto o destinatário dispõem de "informação pragmática", a expressão linguística é a manifestação da "intenção", que o falante tem de alterar a informação pragmática, trazida pelo destinatário, e que o falante tanto pode conhecer quanto subentender (sendo tema ou rema). Para atingir esse objetivo comunicativo, o falante precisa elaborar "formas", que possam sofrer "interpretação" adequada dentro do universo dos "construtores do destinatário", ou seja, o falante precisa operar dentro das formas conhecidas, logo passíveis de interpretação por parte do destinatário.

Assim, o falante "antecipa" o que deve dizer, para ser bem interpretado pelo destinatário; e, a interpretação do destinatário, por sua vez, modela ou "reconstrói" a intenção do falante. Desse modo, o que o esquema indica é que a interação verbal denota uma dinâmica cooperativa e estruturada. É cooperativa porque invoca pelo menos dois participantes para funcionar, adequadamente, tal que haja antecipação e reconstrução do conteúdo linguístico. E é estruturada, na medida em que as "formas do falante" devem coincidir com os "construtores do destinatário", em um grau mínimo, que permita a "interpretação". Em suma, as regras formais da língua precisam estar minimamente preservadas, para serem compartilhadas a contento.

Além disso, assim como a gramática gerativo-transformacional chomskyana, o funcionalismo também aponta capacidades específicas, que estão diretamente relacionadas ao aprendizado de línguas. No entanto, de acordo com Croft (1991), a grande distinção entre as perspectivas chomskyanas e as funcionalistas está na motivação para sua teoria, isto é, enquanto a primeira aposta todas as suas fichas 
em um elemento estritamente biológico (inato) existente no cérebro humano (e apenas no desta espécie), o qual daria conta de aprender qualquer gramática natural a partir de um conjunto de input restrito, a gramática funcional, apesar de também acreditar na existência de fatores biológicos favoráveis à aquisição da linguagem, empreende maiores esforços no estudo da evolução humana em favor da adaptação da espécie ao meio social. Por isso, as visões funcionalistas da linguagem apresentam a "capacidade linguística" como uma dentre outras capacidades que tendem a favorecer a comunicação.

Alinhado a esta percepção, Dik (1997a) aponta cinco capacidades que, segundo ele, desempenham papéis essenciais na comunicação linguística e, por isso, não poderiam ficar de fora do M.NLU: linguistic capacity (capacidade linguística), epistemic capacity (capacidade epistêmica), logical capacity (capacidade lógica), perceptual capacity (capacidade perceptual) e social capacity (capacidade social).

Givón (1995) também apresenta algumas premissas, para caracterizar essa concepção. Dentre elas, destaca que:

(a) a linguagem deve ser entendida como uma atividade sócio-cultural, considerando-se a dialética;

(b) a estrutura serve a funções comunicativas e cognitivas, nunca o contrário, pois os estudos se dão da função para a forma;

(c) a estrutura é não-arbitrária, motivada e icônica, o que significa dizer que até mesmo a sintaxe tende a refletir aspectos comunicativos, como grau de informatividade e de apreensão do real;

(d) mudança e variação estão sempre atuantes;

(e) o sentido é contextualmente dependente e não-atômico, o que demanda entender que a pragmática da visão de mundo não pode ser desconsiderada, de modo que "nossa gramática e nosso léxico refletem - e são moldados por - uma visão construída de nosso universo." (GIVÓN, 2012, p. 16);

(f) as categorias não podem ser vistas como discretas, pois só funcionam na fala, quando relacionadas, inclusive em uma estrutura cognitiva;

(g) a estrutura é maleável e não rígida, de modo que as regras de gramática permitem e prevêm algumas exceções, que podem atuar, até mesmo, para melhor adaptar determinado conteúdo a um contexto comunicacional; 
(h) as gramáticas são emergentes, isto é, não é possível prever aprioristicamente um modo gramatical único e universalmente replicável, por isso a ideia de se produzir um computador capaz de conversar adequadamente não ganharia campo, se considerássemos este pólo.

Desse modo, podemos entender a partir de Dryer (1999) como o funcionalismo entende a perspectiva de produção de uma gramática universal. Este autor, ao contrastar a abordagem formalista chomskyana com as funcionalistas, afirma:

O ponto de vista das teorias que caracterizam a habilidade linguística humana inata é rejeitado pelos funcionalistas porque assume (ou parece assumir) que fatores cognitivos gerais e função comunicativa não representam qualquer papel para explicar por que as línguas são como são. ${ }^{22}$ (DRYER, 1999, p. 04)

Dada a fala acima, é possível depreender que o funcionalismo se apresenta como um modelo eficiente para descrição e análise de línguas, a despeito de alguns linguistas o considerarem uma proposta "ateórica", uma vez que evita "metalinguagens", que não só restringem a leitura a um nicho introduzido nos rudimentos teóricos específicos, mas, também, segundo o autor, ata a análise a um pressuposto teórico que tende a "adaptar" os dados, para que eles preencham os pressupostos da teoria e não o contrário.

Abaixo, há um trecho em que Dryer (1999) explica, brevemente, sua postura favorável ao funcionalismo:

\begin{abstract}
Em outras palavras, frequentemente parece que os mecanismos formais fornecidos pelas metalinguagens de teorias formais são lastimavelmente inadequados para descrever os fenômenos reais em questão e, por essa razão, é duvidoso se as metalinguagens das teorias formais oferecem, de fato, muito para o objetivo de atingir adequação descritiva (ou mesmo adequação observacional) e, portanto, ao objetivo de caracterizar o conhecimento subjacente ao comportamento linguístico. ${ }^{23}$ (DRYER, 1999, p. 14, tradução nossa)
\end{abstract}

\footnotetext{
22 Texto original: "The view of theories as characterizing the innate human linguistic endowment is rejected by functionalists because it claims (or appears to claim) that general cognitive factors and communicative function play no role in explaining why languages are the way they are."

${ }^{23}$ Texto original: "In other words, it often looks like the formal mechanisms that the metalanguages of formal theories provide are woefully inadequate for really describing the phenomena in question, and for that reason it is dubious whether the metalanguages of formal theories really do offer much towards the goal of achieving descriptive adequacy (or even observational adequacy) and hence of characterizing the knowledge that underlies linguistic behavior."
} 
Assim, retomando a relação entre o olhar gerativo-transformacional e os funcionalismos, é possível entender que estes aceitam a presença do elemento cognitivo, porém o reconhecem como mais um item essencial ao desenvolvimento das relações pragmáticas, passíveis de serem construídas apenas em e por meio da interação.

\subsection{Cognitivistas}

Conforme foi discutido até o momento, a linguística se fundamenta como área autônoma, sustentando a demanda de se posicionar como um fazer científico próximo ao das ciências exatas. Assim, (cor)responde a um modelo de saber-fazer bastante almejado nas sociedades modernas e pós-modernas, ou seja, aquele que pode apresentar as causas formais dos fenômenos em disputa.

Contudo, seu objeto de análise, as línguas humanas, assume como uma de suas mais importantes características, a variabilidade. Falar de modo adequado é, essencialmente, conseguir se adaptar ao uso linguístico, o que significa reconhecer que há um contexto social, interlocutor(es) e - por que não ressaltar? - a dificuldade de orientar o próprio discurso, isto é, depender, dentre outras coisas, da cognição. Daí, os falantes terem de enfrentar os dilemas ordinários dos "maus entendidos", pois, conforme já afirmara Agnes Heller (apud PATTO, 1993), falar é assumir ser sempre mal interpretado.

Desse modo, surge na linguística uma subárea que se propõe a pensar sobre o papel da linguagem dentro da cognição, entendendo esta como uma ciência essencialmente multidisciplinar, de modo que a linguagem seria apenas mais uma das facetas cognitivas passíveis de análise. Ou seja, a linguística cognitiva vem para refletir sobre o que estaria em jogo na capacidade de falar e, mais do que isso, o que é demandado para se comunicar, sabendo que portamos uma identidade, estamos inseridos em um ambiente repleto de símbolos construídos sócio-histórica e dialeticamente (sendo a própria linguagem um deles), e, sobretudo, apontando que buscamos, por meio do instrumento linguístico, atingir outras "mentes", por sua vez, igualmente portadoras de identidades sociais.

Pensando nesse desafio é que se apresenta o pólo cognitivista da linguagem. Apesar de se situar em bases e conceitos diversos entre si, Janda (2015) aponta 
que é possível ressaltar pontos em comum, o que faz da linguística cognitiva um ramo autêntico, ao invés de uma miscelânea de áreas em contato. Em suas palavras:

\begin{abstract}
A linguística cognitiva busca por meio de suas pesquisas observar as motivações que orientam os fenômenos linguísticos, reconhecendo que, por vezes, muitas das variantes disponíveis podem ser igualmente motivadas, de modo que a escolha por parte do falante tende a refletir uma convenção específica de determinada língua; e isso não pode ser plenamente previsto. Então, embora as motivações variem (e, frequentemente, dado fenômeno possa ser motivado por múltiplos fatores em uma determinada língua), em um nível abstrato, essas motivações seguem um padrão consistente: todos os fenômenos linguísticos são dotados de significado; as categorias linguísticas são categorias radiais com protótipos; o significado é baseado na experiência, que está assentada em um corpo, e elaborado através de metáfora, metonímia, e usos mesclados de ambas; a construção de sentido determina como a realidade percebida pode ser classificada em informação de primeiro e informação de segundo nível (discursivo); etc. ${ }^{24}$ (JANDA, 2015, p. 133, tradução nossa)
\end{abstract}

O que Janda (2015) ressalta é que a linguística cognitiva, de um modo mais amplo, não assume esquemas dualísticos, que permitam predizer dados a partir de posicionamentos teóricos. Reflete, portanto, o lugar de uma ciência oriunda do fracasso, que foi a tentativa de produzir máquinas linguísticas. Sobre isso, Pinker (2004, p. 252) discute que "a parte da memória é fácil para computadores e difícil para pessoas, e a parte da tomada de decisões é fácil para pessoas [...] e difícil para computadores".

O autor não chega a essas conclusões, porém, assumindo uma perspectiva funcionalista, na qual o fracasso seria previsível, uma vez que a linguagem depende e se faz no uso, no contato extralinguístico e, mesmo, considerando-se a construção de experiências prévias, que dizem respeito ao contexto e aos destinatários. O ponto relevante é assinalar que essas e outras variáveis, uma máquina - ou, nas palavras de Pinker (2004), uma "cabeça falante" - não é capaz de avaliar a fim de responder adequadamente.

\footnotetext{
${ }^{24}$ Texto original: "Cognitive linguistics searches for the motivations that drive linguistic phenomena, recognizing that sometimes several variants are equally motivated, and the choice of which one succeeds is a language-specific convention that cannot be fully predicted. Though the motivations vary (and often a given phenomenon may be multiply motivated in the system of a given language), at an abstract level, these motivations yield a consistent pattern: all linguistic phenomena are meaningful; linguistic categories are radial categories with prototype effects; meaning is grounded in embodied experience and elaborated via metaphor, metonymy, and blends; construal determines how perceived reality is sorted into foregrounded and backgrounded information; etc."
} 
Uma máquina pode, sim, reproduzir a cadeia da fala, conforme proposto por Denes; Pinson (apud BALIEIRO JR., 2009, p. 190), além dos esquemas de recepção e produção, como sugerido por Garman (apud BALIEIRO JR., 2009, p. 193). Porém, nunca será capaz de (re)produzir as funções do uso.

Croft; Cruse (2004), com quem nos alinhamos para propor as perspectivas dispostas acima, propõem três grandes princípios para pensar a linguagem sob 0 olhar da linguística cognitiva:

1. A linguagem não é uma faculdade cognitiva autônoma;

2. A gramática é conceituação;

3. O conhecimento da língua emerge de seu uso. ${ }^{25}$ (CROFT; CRUSE, 2004, p. 01, tradução nossa)

O primeiro princípio disposto é uma oposição clara à tradição gerativotransformacional, cuja hipótese central é a de que seria possível isolar, em algum momento da evolução humana, o desenvolvimento de um módulo da linguagem (análogo ao da visão), apartado, por sua vez, de todas as demais habilidades cognitivas não vinculadas à produção linguística.

Para apresentar um contraponto, citemos Jackendoff (2009). Dialogando com a tradição gerativo-transformal, este autor propõe que a neurociência cognitiva da linguagem seja dividida em dimensões de estudo da mente/cérebro, de modo que a linguagem passaria a compor apenas uma delas.

A fim de promover uma melhor visualização, copiamos abaixo a tabela de Jackendoff (2009, p. 05) ${ }^{26}$ e nela assinalamos, em negrito, o lugar ocupado pela linguagem:

Ways of studying the mind/brain

Dimension 1

Neuroscience (brain) vs.

Cognitive Science (mind/funcional properties) vs

Behavior and phenomenology

- plus relations among the three

\section{Dimension 2}

${ }^{25}$ Texto original: "1. Language is not an autonomous cognitive faculty; 2. Gramar is conceptualization; 3. Knowledge of language emerges from language use."

${ }^{26}$ A tabela consta tal qual no original. 
Steady state vs.

Individual development vs.

Evolutionary development

Dimension 3 ("Vertical" capacities or "modules")

Vision vs.

\section{Language vs.}

Motor control vs.

Abstract thought vs.

Dimension 4 ("Horizontal" division; applies to all "vertical" capacities)

Data structures (mental structures) vs.

Procesing capacities

Working memory vs.

Long-term memory vs.

Attention vs.

Learning

No que concerne ao segundo princípio apresentado por Croft; Cruse (2004), ele se opõe, claramente, à semântica das condições de verdade e à ideia de que haveria uma capacidade humana inata para a linguagem.

Dentro da semântica de condições de verdade, é aceito que a partir da semântica de uma língua-objeto seria possível avaliar o mundo em termos de "verdade" (truth) e "falsidade" (falsity). Desse modo, a crítica que Croft; Cruse (2004, p. 02) elaboram é que aquilo que conseguimos depreender d'o mundo seria, antes, um modelo de mundo, visto que "a língua é uma percepção em tempo real e uma produção de uma sequência temporal de unidades discretas e símbolos estruturados"27.

O nome mais importante que encabeçou este segundo princípio, alinhando-se ao que foi proposto por Croft; Cruse (2004), é Langacker. Conforme este autor, uma característica proeminente da habilidade cognitiva humana é justamente a de conceituação da experiência que se pretende comunicar, bem como a própria

\footnotetext{
${ }^{27}$ Texto original: "[...] language is the real-time perception and production of a temporal sequence of discrete, structured symbolic units."
} 
conceituação do conhecimento linguístico (lexical e gramatical) partilhado entre os membros de uma comunidade de fala.

Por fim, o terceiro princípio proposto por Croft; Cruse (2004) é uma crítica a ambos os modelos dispostos acima, isto é, à tradição gerativo-transformacional e à semântica das condições de verdade, pois assume que tanto as categorias quanto as estruturas de análise (semânticas, sintáticas, morfológicas e fonológicas) são construídas pela cognição humana somente a partir de ocasiões específicas e que remetam ao uso.

Tendo feito essa breve discussão sobre os campos da linguística e seu lugar de saber-fazer, logo de poder em nossa sociedade, poderíamos concluir apontando para o fato de que o nosso "arsenal" se construiu, em um primeiro momento, um tanto apartado das questões concernentes, especificamente, à tradição indigenista.

A começar, por um longo período, as muitas línguas indígenas e africanas foram deixadas de lado ou consideradas variantes menos desenvolvidas (dentro de uma lógica evolutiva) em comparação com a língua norteadora de gramáticas ao redor do mundo, ou seja, o Latim.

Assim, no começo das pesquisas e construção do cânone, as línguas subrepresentadas ocuparam pontos cegos dos espaços organizacionais ${ }^{28}$ e teóricos das instituições de cultura, ensino e pesquisa, que se nos atravessam.

Adiante, a linguística se deparou com as contribuições que, por exemplo, línguas indígenas e africanas poderiam trazer às discussões teóricas. A partir da observação de suas estruturas e usos, muitas teorias em voga puderam ampliar seu alcance de proposições descritivas e analíticas. E é por isso que trabalhos como este são possíveis.

Apesar disso, no Brasil, ainda podemos dizer que representa uma luta pela desnaturalização do instituído tratar de línguas subrepresentadas. Pensando institucionalmente sobre esta questão, tomemos a fala de Moura (1993, p. 37):

De qualquer modo, é sempre bom lembrar que falar do institucionalismo e suas diferentes ramificações é falar de uma luta pela autonomia, pela desnaturalização do instituído, pela criação de novos modos de existência. (MOURA, 1993, p. 37)

\footnotetext{
${ }^{28}$ Assim como constam nos escritos de/sobre Bleger, assumiremos Organização e Instituição sem realizar qualquer distinção.
} 
Então, podemos questionar em que medida as instituições, que abarcam os cânones de produção científica, difundem vetores instituídos e instituintes e, mais, como operam institucionalizações, criadoras de "verdades", que tendem a apagar os efeitos instituintes. Ou seja, é necessário pensar como a produção linguística ainda tem atuado como um espaço, que tende a mascarar as naturalizações advindas do poder dominante.

Para começar, devemos destacar que toda ciência e suas instituições de ensino e pesquisa foram inventadas, ou seja, pertencem a determinado tempo e espaço (HILSDORF, 2003), de modo que não foi sempre uma verdade que as pessoas precisariam se situar em um espaço organizacional/teórico para estarem aptas à produção e promoção de saberes. Tampouco, é natural que precisemos nos alinhar a determinadas instituições para operarmos, criticamente, conteúdos técnicos e/ou científicos. Antes, poderíamos postular o oposto, sobretudo se considerarmos a passagem de ensinamentos e conteúdos para a vivência em aldeias ou pequenos agrupamentos, em que não é requerido um espaço institucional ou organização ou, mesmo, a produção ininterrupta de teorias. Sobre isso, Baremblitt (1987) discorre:

\footnotetext{
O institucionalismo estaria interessado na crítica do que se chama a profissionalidade e a especificidade, ou seja, pontos cegos que todo corpo doutrinário tem ao ocupar-se de uma coisa e os escotomas que se criam, porque todo corpo disciplinar, para poder implantar-se como conhecimento na sociedade, tem que fazê-lo através de postulações teóricas mas também de organizações. (BAREMBLITT, 1987, p. 114)
}

Dessa forma, as variadas e diversas teorias estão assentadas em suas próprias e contínuas invenções, que de instituintes - como a ideia de produzir um saber novo sobre determinada área -, passa(ra)m a instituídas, ainda que abarquem em si movimentos de transformação institucional.

Aliás, a presente Tese poderia ser tomada como um analisador para esta questão. Recorrendo-se a um mecanismo instituído (os campos teóricos que antecedem esta produção), abriga elementos instituintes, ao tomar como um dos temas (analisador) a prática institucional que é a produção de uma Tese, de modo a remeter à práxis acadêmica.

Assim, se por um lado este esboço corrobora a necessidade de um espaço para este debate e produção científica, cuja prerrogativa cristalizada aponta que a 
apreensão de determinado conteúdo programático perpassa critérios prévios de avaliação (como cumprir determinada carga horária em disciplinas para estar apto à qualificação e, por sua vez, apto à Defesa), por outra via, permite colocar em análise/decomposição a própria organização. Sobre isso, Guirado (1987, p. 10) aponta para o fato de que esse exercício é não somente necessário, como esperado "[...] que os agentes e grupos da instituição, "meta-aprendendo", possam também observar, refletir e buscar os sentidos do "vivido institucional'"'.

Adentrando horizontes próximos, Freire (2002), ao discutir a "concepção problematizadora da educação" critica, veementemente, a "verbosidade do narrar", isto é, a separação entre o "vivido institucional" (incluso espaços entendidos como distantes do acadêmico, como as aldeias) e as instituições (denominadas tradicionais) de ensino/pesquisa, cujos elementos instituídos abarca(va)m relações calcadas na horizontalidade, separação objetiva de conteúdos programáticos e consequente desinvestimento na humanização cognoscente.

No vetor instituinte das instituições, Freire (2002) ressaltara que a aprendizagem desvinculada da práxis se apresenta como alienação com vistas à manutenção das instituições tradicionais, ao que destaca o capitalismo, muitas vezes, incorporado à prática nas instituições de ensino superior, por meio de critérios bastante quantitativos:

_Quantos artigos foram produzidos este ano?

Igualmente para Bleger, as instituições voltadas à produção de conteúdos teóricos, uma vez que queiram se inserir na esteira do instituinte, não deveriam desprezar os elementos de subjetividade, própria a cada um dos campos de saberfazer. Desse modo, um linguista não precisa se comportar como um protocolador de questionários de língua, antes poderia se ater a questionários de funções da língua, que, em última instância, diz sobre o movimento vital que é o "falar". Mas como bem diz Guirado (1987), os protocolos (que podem assumir a forma de teorias estruturadas para lidar, previamente, com os dados) tendem a atuar para apaziguar nossa ansiedade, por ofertarem a (requerida, por vezes) segurança do instituído:

Toda situação nova desperta ansiedade. Esta ansiedade é maior quanto menor for a distância entre os conteúdos internos daquele que se propõe à aprendizagem e aquilo que se propõe a ser "apreendido"; ou seja, quanto maior for a identificação do sujeito que se propõe a conhecer com o objeto do conhecimento. No interjogo da ansiedade que a identificação desperta e de sua superação quando da incorporação simbólica como conteúdo 
intelectual ou como representação consciente, é que se delineia o subjetivo, o caracteristicamente humano. Esta é a objetividade única no ato de aprender, produzir e conhecer. (GUIRADO, 1987, p. 04)

A discussão acima procede porque, segundo Bleger, todo indivíduo é grupo e, em sendo grupo, é instituição. Assim, a instituição teórica precisa cooptar o indivíduo pesquisador. Desse modo, a organização/instituição somente é possível porque o ego organizado (diferenciado) da personalidade demanda a formação de regras, de modo que "a Organização é parte da personalidade porque a personalidade é também organizada" (GUIRADO, 1987, p. 18). Nesse sentido, a desorganização institucional/teórica poderia reverberar na desorganização (até mesmo, total) do fazer científico, uma vez que indivíduo, grupo e instituição seriam instâncias entendidas como indissociáveis. Por isso, as resistências à mudança (como a manutenção de mecanismos burocráticos) surgem como proteção para evitar o contato com as ansiedades paranoides, em que se teme o desconhecido, que existe dentro do conhecido. Na prática, é muito difícil sustentar um lugar de linguista cientista sem recorrer às "metalinguagens das teorias formais".

Frente a mudanças, o novo impõe a necessidade de experimentação performática, em que modelos estereotipados e, portanto seguros, podem não ser mais adequados, o que coloca em risco a sociabilidade organizada. Sobre isso, Guirado (1987, p. 17) explica que "a personalidade ou a identidade do sujeito se dá, sempre pelo interjogo de um ego sincrético e um ego organizado."

O ego sincrético abarcaria impulsos agressivos, aspectos simbióticos e ambíguos. Tem como característica formação de vínculos, em que não se diferencia o que é sujeito do que é objeto da libido. Remete à vinculação inicial (com a função materna), em que vigora o vínculo simbiótico ou sincrético (sociabilidade sincrética). Sobre isso, Guirado (1987, p. 16) esclarece que "a posição gliscrocárica se define pela vivência da ansiedade catastrófica, pelas defesas de cisão e projeção maciças e pela relação com um objeto aglutinado, viscoso".

Já o ego organizado faria discriminação (jamais plena ou absoluta) entre sujeito e objeto da libido, o que permite, por sua vez, a formação de quadros relacionais regidos por normas e regras do meio (sociabilidade organizada). Desse modo, seria possível a passagem para relações mais diferenciadas, que permitam a construção da identidade, com relativa delimitação entre self, mundo e outros. 
Assim, podemos tentar trazer um movimento novo a cada uma de nossas produções científicas, porém o único modo de fazê-lo, sem promover uma desorganização institucional, é calcá-lo em antecedentes, que podem ser traduzidos na presente experiência como o espaço das referências bibliográficas. São nelas que nos assentamos para que o instituinte seja aceito pela instituição.

O caminho segue tal que estereotipias muito rígidas tendem a levar à burocratização, inclusive nos espaços de fazer científico. Isso levaria à imobilidade e, como consequência, o que podemos verificar é:

[...] a normatização da conduta para que se atinjam os objetivos explícitos transforma-se num fim em si, exigindo a fidelidade dos integrantes, de maneira que a sua perpetuação enquanto organização torna-se a meta." (GUIRADO, 1987, p. 21).

Ou seja, os sujeitos da organização podem vir a ser cooptados pelo desejo instituído de manter a instituição. E, para isso, submetem a personalidade à indiferenciação própria da posição gliscrocárica. Por isso, por vezes, pensamos em um cientista como o cientista da teoria $X$. Chomsky é um exímio filósofo, todavia, no campo da linguística, ele sempre será visto como representante da tradição gerativotransformacional.

Conforme Arendt (1999) discutiu sobre o caso de Eichmann, justamente por haver uma indissociabilidade entre pessoa, grupo e instituição, traços da experiência, a que ela denomina como "o mal" (sem nos determos na problematização referente às dicotomias morais, bom versus mau), eles não podem ser tomados como uma entidade autônoma, isto é, que existe somente encarnado em um sujeito. Ora, Chomsky é mais do que um "chomskiano".

Desse modo, quando respondemos por uma instituição/alinhamento teórico, tendemos a assumir os propagados papeis instituídos, de modo que se a maré diz, por exemplo, que línguas subrepresentadas não agradam ao capital simbólico, cogitamos mudar de área, e, portanto, produzimos um sintoma a partir de uma demanda institucional.

A questão é que a instituição sempre trará suas demandas, que, por sua vez, respondem e dialogam com outras demandas institucionais. Porém, o que marca a Universidade como um campo privilegiado é que, teoricamente, somos instigados a 
"lidar com a instituição enquanto totalidade" (GUIRADO, 1987, p. 08), através da prática continuada e pautada pela "intervenção investigadora".

Esse diferencial poderia incidir nas tarefas ordinárias, de modo a expor as ambiguidades, que mascaram os conflitos subjacentes a toda e qualquer teoria. Estes, por sua vez, são tanto parte da dinâmica institucional quanto imprescindíveis, uma vez que mobilizam à ação, de modo que "é necessário transformar a ambiguidade em conflito e os conflitos em problemas" (GUIRADO, 1987, p. 13). Os problemas e as dúvidas são, justamente, o motor das teorias. Se eles se perdem, perde-se o sentido da criticidade teórica.

Além disso, ao contrário do que poderia ser veiculado pelo senso comum, "o que indica o grau de patologia das relações é a ausência de conflitos, ou a ausência de recursos para resolvê-los, bem como sua expressão na forma de dilema e ambiguidade" (GUIRADO, 1987, p. 13). É por isso que um dos mais problemáticos sintomas institucionais é, justamente, o apagamento do conflito potencial(izante), quando nos deparamos com a apatia generalizada.

Como consequência da ausência de conflitos e de problemas, Guirado (1987, p. 14) explica que "quanto maior for o grau de ambiguidade ou de estereotipia (de paralisação, portanto) nas relações entre pessoas e grupos, maior o ataque." Isso significa que o grupo tenderá a se mostrar, cada vez mais, hostil e agressivo contra aqueles, que coloquem a perpetuação da instituição em risco, sem considerar o preço que essa perpetuação cobrará.

Desse modo, existe uma tendência para que as respostas aos "insubordinados"/pretensamente ateóricos se apresentem em graus crescentes de agressividade, podendo chegar, até mesmo, à recorrência a outras instituições burocratizadoras, disponíveis para ameaçar ou penalizar as pessoas, que sinalizem perseguir o instituinte possível e desejado em cada uma das teorias em voga.

Por fim, devemos lembrar que, no que tange às organizações para promoção de autonomia intelectual, Freire (2002, p. 61) foi instituinte tanto ao propor uma concepção não bancária de educação quanto ao salientar que "pensar autenticamente é perigoso" e, podemos acrescentar que investir em uma prática autônoma e crítica também o é, sobretudo se a crítica se volta ao próprio campo de legitimidade de poder, o do saber-fazer da linguística, colocando em xeque toda uma construção identitária. De todo modo, conforme Hall (2000), na pós-modernidade, 
seria impossível que a desconstrução das perspectivas identitárias não fosse questionada:

Esta perda de um "sentido de si" estável é chamada, algumas vezes, de deslocamento ou descentração dos indivíduos tanto de seu lugar no mundo social e cultural quanto de si mesmos - constitui uma "crise da identidade" para o indivíduo. (HALL, 2000, p. 09)

Tendo proposto essa breve discussão acerca dos pólos da linguística e seus desdobramentos no campo dos vetores de força, que envolvem as perspectivas de poder, trataremos, no capítulo seguinte, sobre o lugar político que o povo PykobjêGavião tem encontrado para construir sentidos para sua identidade, comunidade de fala, autonomia e reconhecimento de língua materna, considerando esta no que concerne à alfabetização e espaços de letramento. 


\title{
3. Para conhecer a comunidade de fala
}

Fizemos uma ciência voltada para alguns e esquecemo-nos das maiorias. Por isso, entre outras coisas, a história que contamos, a geografia que descrevemos, o idioma que ensinamos, tudo enfim, é o espelho de um mundo chamado "desenvolvido", deixando de lado a maior parte da humanidade, mergulhada nas trevas da exploração do chamado "Terceiro Mundo", ou melhor, de um "mundo dominado", onde as classes dominantes atuam sobre as classes dominadas, independentemente de países ou nações. (SOUZA, 1991, p. 10)

As concepções de linguagem e sociedade são dialeticamente inseparáveis. Halliday (1978) afirma que a aquisição da linguagem (proto-linguagem ${ }^{29}$ ) é um fato social, porque só pode se dar em um contexto disparador (proto-situação comunicaciona ${ }^{30}$ ), de modo que a realidade é apreendida, desde sempre, como uma construção codificada a partir e por meio do sistema semântico e lexicogramatical. Sobre isso, esclarece ainda:

\begin{abstract}
O texto é a forma linguística da interação social. É uma progressão contínua de significados, que se combinam simultaneamente e em sucessão. Os significados são as seleções feitas pelo falante a partir das opções que colaboram para o significado potencial; o texto é a efetivação desse significado potencial, o processo de escolha semântica. As seleções de sentido derivam de diferentes origens funcionais, e são detectadas no curso de sua realização como estrutura lexicogramatical. Em nossa terminologia linguística popular, o "significado" é apresentado como "formulação" - o que, por sua vez, é expresso como "som" ("pronúncia") ou como "escrita". A linguística popular, aliás, revela nossa consciência da natureza da linguagem, formada por três ${ }^{31}$ estratos de conteúdo. ${ }^{32}$ (HALLIDAY, 1978, p. 195, tradução nossa)
\end{abstract}

Para trabalhar no campo da linguística com a qual nos alinhamos teórica e metodologicamente, portanto, é essencial lidar com a sociedade, na qual as

\footnotetext{
${ }^{29}$ Nas palavras do autor: "proto-language".

${ }^{30} \mathrm{O}$ autor denomina como "proto-contexts" ou "language engendering functions".

${ }^{31}$ Nota nossa: Caffarel; Martin; Matthiessen $(2004$, p. 10) discutem que a linguagem tenha evoluído de uma organização de estratificação binuclear (conteúdo e expressão) para uma organização com três núcleos paradigmáticos, conforme assume Halliday (1978). Seriam eles: dois estratos de conteúdo, semântica e lexicogramática, e um estrato de expressão, disposto como a fonologia, a ser distinguida em signo de fala e signo de escrita.

${ }^{32}$ Texto original: "The text is the linguistic form of social interaction. It is a continuous progression of meanings, combining both simultaneously and in succession. The meanings are the selections made by the speaker from the options that constitute the meaning potential; text is the actualization of this meaning potential, the process of semantic choice. The selections in meaning derive from different functional origins, and are mapped on to one another in the course of their realization as lexicogrammatical structure. In our folk linguistic terminology, the "meaning" is represented as "wording" - which in turn is expressed as "sound" ("pronouncing") or as "spelling". The folk linguistic, incidentally, shows our awareness of the tristratal nature of language."
} 
concepções de identidade e os papeis comunicacionais são engendrados, de modo a formar aquilo que se convencionou denominar como indivíduos, termo este que remete à indivisibilidade da condição subjetiva, que se coloca no texto, tal qual proposto por Halliday (1978). Desse modo, cabe-nos questionar o que significa portar uma identidade.

Signorini (1998, p. 335) propõe três concepções de identidade: (a) identidade como permanência no tempo; (b) identidade como unidade dialética; (c) identidade como construção ideológica.

Sobre a manifestação das distintas proposições teóricas para entender identidade e suas relações linguísticas, Ribeiro (2006) afirma:

De fato, as identidades dos indivíduos têm implicações mútuas e múltiplas
em suas relações com a língua. Língua e cultura aprisionam e libertam ao
mesmo tempo. A língua não constrói, por si só, a "identidade", mas parece
permitir uma mobilidade dentro do processo identificatório que desloca e
reestrutura componentes da identidade do indivíduo e da sociedade.
(RIBEIRO, 2006, p. 95)

Assim, cabe questionar o que significa ter como identidade a indígena, compondo um país que neglicencia e promove um extermínio contínuo desta minoria. Extermínio este, por vezes, apagado simbolicamente em nome de um ideal libertário de prosperidade, como se as populações indígenas representassem um atraso para as identidades pretensamente cumpridoras da norma desta nação, cuja bandeira expõe como lemas centrais: "Ordem e Progresso".

Refletindo sobre o lugar imaginário que o ideal de prosperidade representa na composição das identidades, novamente Rodrigues (2006) explica que:

[...] o papel primeiro da norma na modernidade é atuar em favor da ordem, como fator de diminuição da incerteza, da ambivalência, do desenquadramento, classificando e ordenando o que é considerado estranho. A norma passa a existir para desestranhar o estranho, para classificá-lo, para ordená-lo. [...] Muitas vezes os processos de normatização são processos de colonização cultural. (RODRIGUES, 2006, p. 113)

Desse modo, o que temos acompanhado é um movimento de normatização da identidade do indígena, neste país. Difunde-se, cada vez mais abertamente, a ideia de que os direitos humanos podem ser flexibilizados (SANTOS, 2009), como 
se fossem um "pequeno sacrifício"33, que alguns grupos (em geral, minoritários) devem estar dispostos a fazer pelo bem do coletivo, sem que, todavia, seja problematizado a quem responde e interessa tal ordenamento do coletivo.

Ainda nessa linha, vale assinalar que pensar o problema da ocupação indígena guarda muitas semelhanças com a situação enfrentada pelas classes economicamente mais vulneráveis da sociedade.

Segundo o antropólogo indigenista, Eduardo Viveiro de Castro, em entrevista concedida à jornalista Eliane Brum, ao El Pais (2014), tal raciocínio é válido porque acompanhamos um processo de "empobrecimento do índio". Em suas palavras:

\begin{abstract}
O que aconteceu com a história do Brasil é que foi um processo circular de transformação de índio em pobre. Tira a terra, tira a língua, tira a religião. Aí o cara fica com o quê? Com a força de trabalho. Virou pobre. Qual foi sempre o truque da mestiçagem brasileira? Tiravam tudo, convertiam e diziam: agora, se vocês se comportarem bem, daqui a 200, 300, 400 anos, vocês vão virar brancos. Eles deixam de ser índios, mas não conseguem chegar a ser brancos. Pessoal, vocês precisam misturar para virar branco. Se vocês se esforçarem, melhorarem a raça, melhorarem o sangue, vai virar branco. O que chamam de mestiçagem é uma fraude. $O$ nome é branqueamento. E é o que estão fazendo na Amazônia. É re-colonização. O Brasil está sendo recolonizado por ele mesmo com esse modelo sulista/europeu/americano. Essa cultura country que está invadindo a Amazônia junto com a soja, junto com o boi. $E$ ao mesmo tempo transformando quem mora ali em pobre. E produzindo a pobreza. O ribeirinho vira pobre, o quilombola vira pobre, o índio vai virando pobre. (BRUM, 2014, s/p)
\end{abstract}

O que o excerto acima discute é que existe uma identidade dominante e ela é, essencialmente, branca. Essa identidade trabalha para naturalizar seus privilégios com base na falácia da meritocracia -, afirmando que é possível atingi-los, uma vez que o indivíduo seja capaz de aderir à norma dominante. Contudo, ao longo do processo de apagamento da alteridade, o que ocorre é a formação de outra alteridade dentro da identidade dominante, isto é, a identidade do indígena se transfigura na identidade do pobre. Sobre isso, Ferreira (2006) explica:

O mesmo (a identidade dominante) funciona, nesse caso, como o outro dos eus marginais, cuja "percepção de si" ocorre em referência àquilo que tem status de normalidade. Nesse sentido, o mesmo é aquela instância que, por se colocar como maioria, se coloca também como representante do que se

\footnotetext{
${ }^{33}$ Um exemplo é a mais recente aprovação de um congelamento orçamentário de vinte anos, que trará impactos devastadores sobre instituições de proteção ao indígena, como a Funai, conforme brevemente discutido aqui: https://www.socioambiental.org/pt-br/blog/blog-do-ppds/pec-241-vai-congelar-orcamento-da-funai-no-fundodo-poco (Acesso: 28/10/2016)
} 
acredita constituir um certo estado de normalidade. Tudo aquilo que escapa à sua ordem é alteridade. (FERREIRA, 2006, p. 188)

Assim, os correntes massacres das populações indígenas, incluso os sofridos pelos Gavião, não são frutos de um grupo cruel ou desviante destino da norma, antes respondem exatamente àquilo que a sociedade brasileira está, há mais de 500 anos, declarando sobre a identidade do indígena, sua comunidade, língua(s) e usos.

\subsection{Comunidade de fala, língua(s) e usos}

Os Pykobjê-Gavião também são conhecidos na literatura como "Gavião do Maranhão" ou "Gavião do Leste", apesar disso denominam-se como Pycop catëë jë, que significa povo de Pycop. Pycop é uma divindade tradicional da cosmologia Timbira.

Os Pykobjê-Gavião são, segundo Rodrigues (2002), um dos sete povos membros do grande grupo étnico Timbira ${ }^{34}$. Dentre as sete variantes Timbira ou línguas aparentadas, quatro dispõem de trabalhos de descrição e análise linguística com orientação de métodos científicos. São elas: Krahô (SOUZA, 1997), ParkatejêGavião (FERREIRA, 2003; FREITAS, 2008), Apãniekrá-Canela (ALVES, 2004) e Pykobjê-Gavião. Esta variante foi estudada com ênfase nos aspectos fonéticos e fonológicos, por Sá (1999); morfofonológicos, por Amado (2004); e, morfossintáticos, por Silva (2012). ${ }^{35}$

O Pykobjê-Gavião é uma variante linguística que faz parte do Tronco MacroJê, Família Jê, Grupo Timbira (RODRIGUES, 2002, p. 49), conforme consta no quadro disposto abaixo:

\footnotetext{
${ }^{34}$ A denominação Timbira, segundo Nimuendaju (1946), poderia significar "os amarrados" (do tupi: tin (amarrar) + pi'ra (passivo)), em referência às fitas de palha ou faixas trançadas em algodão que esses povos usam em partes do corpo como braços, testa e tornozelos. Timbira é o nome que os não índios atribuíram a esses povos. Entre eles, contudo, o tratamento é por mehẽ, que significa "minha gente", "minha carne". Os sete povos Timbira são: Ramkokramekrá-Canela, Apãniekrá-Canela, Krenjê, Krahô, Krinkati-Gavião, Parkatejê-Gavião e Pykobjê-Gavião. Se houver interesse em conhecer melhor cada um dos povos, sugerimos a leitura de Melatti (1972) e Melatti (1978).

${ }^{35}$ Existe entre os estudiosos a controvérsia quanto ao fato de as sete línguas membros do Complexo Timbira serem línguas aparentadas ou se tratarem, de fato, de dialetos de uma única língua Timbira, que se afastou diacronicamente. Uma evidência a favor dos que apostam na ideia de que os Timbira formaram um grupo único no passado, com apenas uma língua em uso, o Proto-Timbira, é o fato de que todos os indivíduos que falam a língua indígena de seus "avós" (aceitando as variações diacrônicas existentes) conseguem se comunicar entre si através de linguagem verbal e sem recorrer ao PB, que vem ganhando força como língua veicular nos encontros festivos.
} 


\begin{tabular}{|c|c|c|c|c|c|c|}
\hline \multicolumn{7}{|c|}{ Quadro 1 - Tronco Macro-Jê $\hat{A}^{36}$} \\
\hline Família Jê & & & & & & \\
\hline Jê do norte & Apinajé & $\begin{array}{l}\text { Kayapó (A’ukré, } \\
\text { Gorotíre, } \\
\text { Kararaô, } \\
\text { Kokraimôro, } \\
\text { Kubenkrakén, } \\
\text { Menkrangnotí, } \\
\text { Mentuktíre, } \\
\text { Xikrin) }\end{array}$ & $\begin{array}{c}\text { Panará (Krên- } \\
\text { Akrarôre) }\end{array}$ & $\begin{array}{c}\text { Suyá } \\
\text { (Tapayuna) }\end{array}$ & $\begin{array}{c}\text { Timbíra } \\
\text { (Gavião } \\
\text { Piokobjé, } \\
\text { Gavião } \\
\text { Parakatejé, } \\
\text { Krinkatí, } \\
\text { Canela } \\
\text { Ramkokamekr } \\
\text { ã, Canela } \\
\text { Apanyekrã, } \\
\text { Krahô, Krenjé) }\end{array}$ & \\
\hline Jê nordeste & ¡ऍJaikó & & & & & \\
\hline Jê central & ¡Akroá & ÆXabiakrá & Xavante & Xerente & & \\
\hline Jê do sul & ఔIngaín & $\begin{array}{l}\text { Kaingáng } \\
\text { (variantes } \\
\text { regionais) }\end{array}$ & Xokléng & & & \\
\hline $\begin{array}{l}\text { Família } \\
\text { Kamakã }\end{array}$ & やKamakã & ÆKotoxó & ¡Masakrará & ఔMenién & ఔMongoyó & \\
\hline $\begin{array}{c}\text { Família } \\
\text { Maxakalí }\end{array}$ & せKapoxó & やMakoní & ¡Malilí & Maxakalí & ఔMonoxó & §Pataxó \\
\hline Família Krenák & ¡Guerén & $\begin{array}{c}\text { Krenák (Aranã, } \\
\text { Bakuén, Etwet, } \\
\text { Minyãyirún, } \\
\text { Naknyanúk, } \\
\text { Nakpié, Nakrehé, } \\
\text { Nyepnyep, } \\
\text { Pojitxá, Potén, } \\
\text { Yiporók) }\end{array}$ & & & & \\
\hline ¡Família Purí & ఔCoroado & †Koropó & ‡Purí & & & \\
\hline ¡Família Karirí & ¡Dzubukuá & ¡Kamurú & §Kipeá & ¡Sabuyá & & \\
\hline Família Yaté & Yaté & & & & & \\
\hline Família Karajá & Karajá & & & & & \\
\hline Família Ofayé & Ofayé & & & & & \\
\hline Família Boróro & $\begin{array}{l}\text { ॐBoróro } \\
\text { ocidental }\end{array}$ & Boróro oriental & $\begin{array}{c}\text { ¡Otúke } \\
\text { (Kovare(ka), } \\
\text { Kurumina(ka)) }\end{array}$ & Umutína & & \\
\hline Família Guató & Guató & & & & & \\
\hline $\begin{array}{c}\text { Família } \\
\text { Rikbaktsá }\end{array}$ & Rikbaktsá & & & & & \\
\hline
\end{tabular}

${ }^{36}$ Estamos utilizando os nomes propostos por Rodrigues (2002), que fornece informações mais detidas sobre cada uma das famílias e línguas citadas. 
Historicamente, o Pykobjê-Gavião é um povo que, segundo Nimuendaju (1946), manteve-se afastado dos não indígenas até meados do século XIX, devido ao seu ethos belicoso. Sobre isso, Povos indígenas do Brasil (1985) explica:

\begin{abstract}
As crônicas "mostram que os Gavião eram desconhecidos e o temor que inspiravam aos regionais era motivado pelo fato de serem índios e nada mais" (Laraia \& Da Matta: 1967, 76). Mais tarde os Gavião viriam a utilizar esses estereótipos de "bravos" e "selvagens", a fim de amedrontar e afugentar os "civilizados" que haviam se fixado em suas terras. (POVOS INDÍGENAS DO BRASIL, 1985, p. 57)
\end{abstract}

Segundo Nimuendaju (1946) e Barata (1981), a história do contato entre os índios Pykobjê e os cöpẽ pode ser dividida em dois momentos principais.

O primeiro se dá no fim do século XVIII, quando não indígenas criadores de gado ("expansão pastoril") passaram a ocupar as terras secularmente habitadas pelos diversos grupos Timbira, dentre eles os Gavião, gerando, desse modo, inúmeros conflitos, que se estenderam até meados do século $X X$. E o segundo momento do contato também foi marcado por intensas disputas de terras entre índios e os extrativistas ("expansão agrícola"). Esse segundo momento é tido como um período histórico muito mais brutal do que o primeiro e culminou com a "dominação" dos Gavião, por volta de 1850.

Segundo Nimuendaju (1946), foi nessa ocasião de aparente "paz" (subjugação da alteridade) entre Gavião e cöpẽ que ocorreu a ruptura desse grupo indígena, formando uma comunidade Timbira autônoma, denominada Gavião do Pará ou Paracatejê.

Os Parkatejê-Gavião, tal qual são conhecidos hoje em dia, teriam se reagrupado, segundo essa descrição, por vontade de alguns Pykobjê-Gavião, que não aceitaram essa "paz" imposta.

Em 2010, os Parkatejê já eram cerca de seiscentos indivíduos, que vivem em duas aldeias localizadas ambas em Bom Jesus do Tocantins, cidade esta que fica a sudoeste do estado do Pará. Segundo estudiosos, apenas $10 \%$ de sua população fala a língua Parkatejê. $\hat{~}^{37}$.

\footnotetext{
${ }^{37}$ Para maiores informações sobre a cultura dos Parkatêjê, ver: FERRAZ, I. "Os índios Parkatejê 30 anos depois". In: MARTINS, J. S. (Org.) O massacre dos inocentes, a criança sem infância no Brasil. São Paulo: Hucitec, 1993 (p. 21-35). Sobre a língua sugerimos a leitura de Ferreira (2003) e Freitas (2008).
} 
Outro momento histórico importante de contato entre os Pykobjê-Gavião e os não indígenas ocorreu na década de 1950, quando fazendeiros do Sudeste/Nordeste (Minas Gerais, São Paulo e alguns da Bahia), os denominados "paulistas", passaram a buscar a posse de terras, que pudessem lhes permitir acesso fácil à rodovia Belém-Brasília, construída durante o governo do presidente Juscelino Kubitschek.

Esse contexto histórico teve como consequências finais inúmeros conflitos pelas terras dos Pykobjê-Gavião e dos Krinkati, culminando, no ano de 1976, com o ataque de um "fazendeiro paulista" à aldeia de Rubiácea, dos Pykobjê-Gavião. À época, o "paulista" ateou fogo em toda a aldeia, o que obrigou os indígenas a fugirem para a aldeia de Governador, que, segundo relatos, é a aldeia que fundou as demais.

Depois desse ataque, segundo Barata (1993), houve maior preocupação da Funai em resolver a questão da delimitação de TIs (terras indígenas). Portanto, um ano depois desse incidente, os Pykobjê-Gavião tiveram seus limites delimitados pelo convênio Funai/Radam, cujo objetivo era demarcar Tls de, no máximo, 70 mil hectares de extensão. Os Pykobjê receberam 42 mil hectares de terras.

Contudo, atualmente, esse espaço demarcado vem se mostrando insuficiente para a manutenção das condições culturais básicas desse povo. Isso acontece porque a população indígena dos Pykobjê-Gavião ${ }^{38}$ triplicou em número desde a década de 1970 (cerca de 190 pessoas, em 1969, segundo dados do Centro de Trabalho Indigenista $\left.(\mathrm{CTI})^{39}\right)$. Além disso, na área demarcada não há espaços para as tradicionais atividades de caça (a carne animal é a principal fonte de alimentação para esse povo), pesca ("tinguizada", pesca com tingui) e coleta.

Desde o convênio Funai/Radam, de 1977, os Gavião vivem a sudoeste do estado do Maranhão, a cerca de $20 \mathrm{~km}$ do centro da cidade de Amarante, na microrregião de Imperatriz. Dividem-se em, pelo menos, quatro aldeias: Governador, a mais antiga delas, Rubiácea, Riachinho e Aldeia Nova, esta última organizada em meados de 2010. Ao todo, contabilizam cerca de 800 indivíduos, com crescimento populacional médio de $10 \%$ ao ano.

\footnotetext{
${ }^{38}$ A estimativa da população Timbira, atualmente, é de cerca de "nove mil pessoas, distribuídas em 52 aldeias e seis Terras Indígenas" (LADEIRA, 2012).

${ }^{39}$ O Centro de Trabalho Indigenista (CTI) é uma entidade da sociedade civil, sem fins lucrativos e que foi fundada em 1979. Discute o empoderamento dos povos indígenas frente a seus territórios, esclarecendo sobre o papel do Estado para a garantia dos direitos constitucionais.
} 
Apesar de haver disputas internas e eventuais desentendimentos, as aldeias partilham uma unidade cultural e há intenso convívio, sobretudo em decorrência das festividades tradicionais e laços de parentesco.

Entre os Timbira não é separado um momento específico para a vivência, recriação e transmissão das tradições, ou seja, não há ocasiões reservadas, exclusivamente, à fala dos velhos aos mais novos. Entre esse povo é, justamente, no momento de preparar os rituais ${ }^{40}$, de organizar uma grande pesca, caçada ou coleta que a Tradição emerge ${ }^{41}$. Para eles, caçar e pescar são atos que remontam a um passado mítico (tempo/espaço mítico, para os Timbira, é, resumidamente, quando não havia diferenciação entre humanos e animais, céu e terra, caos e ordem cósmica) e que requerem conhecer, respeitar e se harmonizar com as forças que formam a natureza.

Considerando a dualidade própria da vivência Timbira, o sujeito que é considerado um bom caçador (ressaltando que esta é uma prática essencialmente coletiva, porque envolve esquartejamento e distribuição da caça entre parentes próximos, afins e consanguíneos bilateriais) seria aquela pessoa que modificou seu corpo e, por isso, consegue falar a língua da floresta e dos animais que nela habitam. Ou seja, demanda um efeito de mudança performativa que se apresenta no corpo para exprimir potências de identidade (PINTO, 2009). Contudo, na atual situação desse povo, tais momentos são raros, porque os indígenas necessitam de uma autorização dos cöpẽ para poderem pescar e caçar fora de suas áreas delimitadas.

Com tantos empecilhos, não são apenas agricultura, caça e pesca que os cöpẽ estão restringindo, mas a vivência cultural e, consequentemente, a transmissão/recriação da tradição Timbira. Sem o conhecimento e a transmissão da tradição, as regras de vivência das aldeias perdem muito de seu sentido.

As relações sociais de parentesco, a tradição que rege as uniões matrimoniais $^{42}$, as divisões nos partidos ${ }^{43}$ e os diversos rituais, muitos dos quais

\footnotetext{
${ }^{40}$ Ladeira (2012, p. 25) ressalta, também que os Timbira, dada sua tradição nômade, não produzem artefatos em cerâmica, preferindo fazer uso de objetos portáteis e, de preferência, duráveis, como as cabaças e materiais produzidos com a resistente folha de buriti.

${ }^{41}$ Para entender os conceitos de Tradição, sugerimos a leitura do capítulo “Qu'est ce que la tradition?”, de autoria de G. Lenclud (1994), situado no livro organizado por M. Detienne, Transcrire les mythologies.

${ }^{42}$ Informações mais detalhadas sobre esses aspectos sócio-antropológicos podem ser obtidas em LADEIRA, M. E. A troca de nomes e a troca de cônjuges: uma contribuição ao estudo do parentesco Timbira. 1982. Dissertação de Mestrado, Faculdade de Filosofia, Letras e Ciências Humanas, USP, São Paulo, 1982.
} 
Melatti (1978) descreve de modo ímpar, perdem sua significação prática. Como resultado, há inúmeros conflitos geracionais (DURKHEIM, 1999).

Para entendermos melhor toda esta problemática, transcreveremos abaixo a redação do indígena Pykobjê Wesley Guaraí Gavião, da aldeia de Riachinho. Todas as redações ${ }^{44}$, que apresentaremos, foram produzidas no Pëmxwyj Hëmpeijxy (Centro de Formação dos Professores Timbira), de 2005, e aplicadas pela Profa Dra. Rosane de Sá Amado.

Nesses encontros, que duravam cerca de oito dias e costumavam acontecer na segunda semana do mês de dezembro, professores indígenas das seis aldeias associadas à $W^{\prime} t y$ Catë ${ }^{45}$ se reuniram para aprender um pouco mais sobre diversos aspectos da ciência escolar ocidental de nível fundamental. Dentre esses aprendizados está o ensino da língua portuguesa, que é não materna para a maioria dos povos Timbira.

As aulas foram ministradas por professores não índígenas graduados e, em geral, especializados na ciência a ser passada. No que concerne ao ensino da língua portuguesa, é dado ênfase para os exercícios de ortografia, de compreensão e interpretação de textos escritos e produção textual.

Nessa ocasião, os indígenas desenvolveram textos escritos em língua portuguesa, a fim de serem trabalhados diversos tipos e gêneros textuais, assim, 0 principal intuito era exercitar a escrita e o uso da língua não materna em contextos variados de uso.

O tema proposto pela docente supracitada para esta produção escrita foi: "Conte como eram as tradições de seu povo no passado, como elas estão sendo preservadas atualmente e como você pensa que elas estarão no futuro". Observemos, então, que o enunciado proposto é capaz de elicitar várias flexões de tempo, pois reflete situações situadas em passado (pontual ou não), presente e futuro (irrealis).

\footnotetext{
${ }^{43}$ Povos indígenas do Brasil (1985, p. 86) explica que "cada indivíduo da aldeia recebe dois nomes (ou mais), dos quais apenas um é usado." Esses nomes respondem pelo lugar que o indivíduo vai ocupar nos encontros cerimoniais. Assim, quem dá e quem recebe o nome estabelecem relações socialmente reconhecidas.

${ }^{44}$ Nos Apêndices, disponibilizamos todas as redações produzidas neste encontro e digitadas por Souza (2011).

${ }^{45}$ Associação (vale a pena remarcarmos que "associação" é um conceito não indígena) criada há cerca de duas décadas com o intuito é reforçar a identidade Timbira. Essa associação conta com o apoio do Centro de Trabalho Indigenista (CTI) e vem desenvolvendo importantes projetos como "Uma Escola Timbira", onde há a formação de professores indígenas e o desenvolvimento de material didático, e "Frutos do Cerrado", uma cooperativa que coleta frutos nativos para serem beneficiados na forma de polpa congelada para venda coletiva a empresas ou pequenos comércios.
} 
Transcrevemos abaixo ipsis littera o conteúdo produzido:

"Eu vou contar uma história que meu avô contou para mim, como era vida deles no passado.

Bom a vida do meu povo era trânquilo, Eles caçavam, pescavam e levavam uma vida boa.

Antigamente, quando não tinha cupẽ, tinham muitas caças, peixes, frutas, terra fértil.

A cultura era muito mais forte as nossas linguas, os costumes, as cantigas, músicas, festas, comidas e outros.

Hoje, atualmente tudo está diferente para nós.

Com a chegada de homem branco, as caças acabaram, tem caças mas poucos, as frutas estão poucas, peixe, madeiras para fazer casas.

E a cultura nossa está comprometida por causa de energia, gravador, rádio, roupa, dinheiro, comidas do cupẽ e muitos costumes de cupẽ que é praticada na aldeia como futebol e etc...

No futuro não sei o que vai ser de nós se vai ficar bom para nós ou não.

Espero que nós os jovens de todas as Etnias lutem pelos nossos direitos. Assim teremos uma vida boa trânquila para nossas crianças e netos." (grifos nossos)

Como podemos perceber por meio da redação de tipo descritivo, de autoria do indígena Wesley Gavião, os elementos culturais que os próprios reconhecem como tradicionais estão, cada vez mais, dispersos.

Diante da proximidade com o mundo não indígena, novas atividades estão sendo introduzidas no cotidiano da vida em aldeia, tais como: ouvir rádio (aliás, os Timbira apreciam os meios de comunicação oral e os utilizam muito, o que contribui para o entendimento de sua mentalidade oral), jogar futebol e usar roupa de cöpẽ. Sobre a dificuldade de ser mehẽ, em imersão em um mundo ideologicamente dominado pelos cöpẽ, Ladeira (2012) observou que os Timbira parecem ter encontrado um modo autônomo e criativo frente às inovações culturais:

O tradicionalismo ou "conservantismo" timbira está marcado pelo uso da
língua como um sistema vivo e operante [...]. Isso não significa que não
incorporem itens ou pautas culturais do cöpẽ (não indígenas), tais como
cachorro, gato, espingarda, panela, escola, forró, tesoura, tecido, miçanga,
bicicleta, entre outros. [...] Em outras palavras, os Timbira, ao firmarem-se
como agentes do processo de contato com a sociedade não-indígena,
demonstram sua capacidade de controle sobre tal abertura, bem como
sobre as transformações que ela acarreta. (LADEIRA, 2012, p. 27)

Em outra redação, agora do indígena Manuel Sansão Gavião, da aldeia de Governador, ainda no tipo textual descrição, há a abordagem da realidade vivida em 
sua aldeia. O tema a ser desenvolvido era: "Descreva sua aldeia e redondeza". Neste tipo de enunciado, o tempo verbal que deveria imperar seria o presente.

"A minha aldeia tem meu povo bem organizado. Elis fazia a sua festa com palha de buriti mas so os mas velho que fazer a sua festa. minha aldeia ja fica mas procima da cidade mais jomeno de dozi quilõmetru è assi os indio trabalha assi de mutirão e nós platamos todas as fruta que nós tiramos sementes e platamos com muito cuidado a aldeia governador temos venti e cinco casa de telha temos cacique que organija com a sua caraquiteristica e povos gavião faze vario tipo de festa nós indio mora na mata aprendemos cir organiza na mata comemos todas as caça e cartitu veado õnça mateiro cutia bandeira etc." (grifos nossos)

Nessa redação, podemos observar a separação geracional, que o enunciador coloca muito brevemente. Esse trecho pode ser re-escrito assim: "Eles (os velhos) faziam a sua festa com palha de buriti, mas só os mais velhos que fazem essa festa". Os velhos querem um tipo de festa, aquela realizada no seu tempo, ao passo que os mais jovens não têm mais tanto interesse nesse tipo de festejo. Essa briga geracional aparece em muitas outras redações desse mesmo apanhado.

Ao longo delas, os indígenas contam que, nos dias de festa, muitos jovens não vão ao pátio para participar dos cantos, porque acham desinteressante essa prática. E remarcam o fato de esses jovens estarem, sempre mais e mais, interessados nas atividades dos cöpẽ e em ganhar dinheiro para comprar utensílios, roupas e objetos não indígenas. Para isso, eles partem à cidade e lá interagem com os cöpẽ, afastando-se dos seus costumes, ritos e história.

Vale destacar aqui que, na tradição Timbira, o pátio (cyy) tem uma importante função social, pois significa o espaço que reúne a dualidade da vida e da simbologia (inclusive, cósmica) da vivência indígena. Sobre isso, Ladeira (2012) discorre:

As atividades cotidianas nas aldeias obedecem a um calendário ritual, regulado pelas atividades do cyy (pátio), centro das aldeias circulares. É no pátio que os homens se reúnem todas as manhãs para decidir quais atividades serão realizadas: se vão caçar, se vão para a roça, se uma festa será iniciada ou concluída e o que precisa ser feito para tanto. (LADEIRA, 2012, p. 40)

Em outra redação, agora do indígena Urbano Gavião, da aldeia de Governador, a relação entre os índios e os cöpẽ é discutida. Além disso, foi 
trabalhado o tipo textual descrição, com o tema: "Conte como é o seu contato com as pessoas da cidade".

Nessa redação, Urbano Gavião conta sobre um problema bastante importante, que abordamos ao tratar das questões históricas, que tocam os Timbira, em geral, e os Pykobjê-Gavião, em específico, que diz respeito às invasões às Tls.

Neste tipo de enunciado, o aluno estaria livre para recorrer a mais de um tempo verbal, podendo se voltar a eventos passados ao do momento da fala. Vamos, então, ao texto:

"O contato com cupê; Porque nós comprar mercadoria tem já todo contato com cupê. Porque temos contanto com branco sobre envasões.

Através da lei temos contato com eles para ajudar em qualquer coisa se estive então entramos contato.

Temos contato com outras pessoa, também de aldeia do meu Povo.

Contato com madereiro e motoqueiro, e com caçadores.

Entramos contato com grupos de comunidade de todas regiões.

Contato com Guajajara neste anos passado.

Semana passado contato com chefes da aldeia.

Temos contato com Povos de fora.

Contato com moradores que mora bem perto." (grifos nossos)

Inserida na problemática das invasões, o indígena Urbano Gavião tratou da difícil proximidade entre as terras demarcadas para os índios e as casas não indígenas, sobre o contato forçado e belicoso com os madeireiros e os motoqueiros, e, também, sobre o contato com os cöpẽ, tanto os que trabalham nos órgãos de proteção aos indígenas, quanto os comerciantes.

A partir do excerto acima, que aborda parte das dificuldades, que os indígenas enfrentam para ter acesso aos seus direitos constitucionais mais básicos, como a preservação da TI, trataremos nos tópicos seguintes sobre a importância que a educação assume para este grupo.

\subsection{Notas sobre educação entre os Gavião}


Segundo o Plano Nacional de Educação, toda população indígena tem direito a uma educação diferenciada, específica, bilíngue e intercultural.

A responsabilidade pela educação passou, sucessivamente, da Funai (Fundação Nacional do Índio) para o MEC (Ministério da Educação) e, então, este órgão Federal repassou a demanda, ainda não bem delimitada, aos estados e municípios ("estadualização"/“municipalização” das escolas indígenas).

A Lei no 10.172, de 09/01/2001 (Diretrizes, §4), acrescenta ainda que: "A educação bilíngue, adequada às peculiaridades culturais dos diferentes grupos, é melhor atendida através de professores índios", o que nos leva a crer que haveria incentivos governamentais para facilitar a entrada de membros da comunidade indígena no ensino superior relacionado à docência. No entanto, essa ainda não é uma realidade entre os Pykobjê-Gavião - apesar de alguns membros da comunidade buscarem chegar ao Ensino Superior, via UFG e outras Universidades públicas do país -, a maior parte das aulas da aldeia ainda não é ministrada por indígenas. Todavia, vale ressaltar que os professores designados para o cargo tendem a respeitar o calendário diferenciado, que as escolas implantaram, de modo a acomodar os elementos culturais apresentados em festejos e ritos.

Apesar dos problemas, que permeiam a formação e manutenção de docência indígena, há muitos benefícios com o funcionamento de uma escola indígena em TI.

A iniciativa de construir uma escola indígena dentro de cada aldeia, para o atendimento diferenciado dessa minoria étnica, parece agradar à comunidade, que tem apresentado níveis cada vez menores de evasão escolar ${ }^{46}$. Além disso, trata-se de um direito assegurado pela 3a Emenda (1989) da Constituição Federal de 1988, no que dispõe sobre a Educação Especial. Ou seja, a comunidade tem cobrado apenas algo assegurado constitucionalmente, como mecanismo de equidade social.

Antes da implantação dessa unidade de Governador, os indígenas, que queriam estudar, precisavam se deslocar até o município de Amarante, que é, por sua vez, o mais próximo das quatro aldeias Gavião.

Esse trajeto (cerca de $20 \mathrm{~km}$ ), além de cansativo, implicava, obviamente, riscos à vida e segurança de todos os estudantes, já que costuma haver tráfego de caminhões de madeireiros pelas estradas de acesso às aldeias. Desse modo, além da possibilidade relacionada a acidentes por atropelamento, havia o medo tanto de

\footnotetext{
${ }^{46}$ Trata-se de uma observação compartilhada comigo pelos professores indígenas. Infelizmente, não tive acesso a dados estatísticos, que corroborem essa percepção.
} 
violências civis (como agressão física e abuso sexual) quanto de haver represália contra o grupo Gavião, que ainda resiste para que sua terra não seja expropriada, ilegalmente.

No entanto, apesar da situação de tensão constante em que vivem com os madeireiros, nem todas as aldeias Gavião desfrutam do direito à escola indígena in loco. A Aldeia Nova, que é a menor em população e também a mais recente aldeia Gavião, no momento desta escrita, ainda não dispunha de infraestrutura educacional para oferecer ensino formal à sua população. Portanto, os estudantes dessas aldeias ainda enfrentam os problemas de mobilidade citados acima.

A solução que muitos indígenas adotam, nesse caso, é irem e/ou mandarem seus filhos estudar nas aldeias Gavião, que possuem escolas, o que promove uma fuga dos jovens e das crianças de suas aldeias de origem para a de seus parentes, ou, então, os estudantes são submetidos à dura rotina mencionada acima para se deslocarem até o município de Amarante.

Estudar em uma escola indígena, além de ser um direito, garante o acesso a uma série de medidas importantes para a manutenção cultural, como a acomodação dos dias letivos ao calendário cultural, apoio da comunidade na participação escolar dos discentes, acompanhamento da dinâmica em aula por, pelo menos, um docente membro da comunidade e, o que mais nos chama a atenção, a conscientização de que é necessária uma formação bilíngue e intercultural.

A preocupação em respeitar o tempo e o modo de aprendizagem de cada indivíduo, enquanto produto de uma organização social que o antecede e com a qual ele se identifica (modus vivendi Gavião), é determinante na apropriação do aprendizado e na formação do senso crítico e político. Além disso, haver sensibilidade e escuta sobre a importância de adotar a língua materna (doravante L1), em sala de aula, demonstra que, apesar de ainda haver muitas medidas que precisam ser melhoradas e, mesmo implantadas, no que diz respeito à educação diferenciada, o Brasil, por meio da Funai (e demais órgãos de proteção), tem apresentado uma posição política diferente da de muitos países, que mantêm as línguas das minorias étnicas restritas a ambientes não formais, o que exclui a escola.

Ainda que não se trate de um povo com contato recente ou cujas relações sempre tenham sido pacíficas com os cöpẽ, como vimos, a língua indígena tem se 
mantido como fator de afirmação cultural. Ou seja, o Pykobjê-Gavião continua a atuar como língua de comunicação interpessoal dentro das aldeias e é a língua materna de $100 \%$ deste povo.

Diante disso, o PB costuma a ser ensinado apenas em idade escolar, isto é, por volta dos sete anos. Contudo, sabemos haver letramento, por meio dos veículos midiáticos disponíveis, dentre os quais destacamos 0 recente acesso a computadores e às redes de internet.

Desse modo, é possível observar ${ }^{47}$, que as novas gerações estão sendo mais expostas à língua portuguesa, de maneira similar ao que ocorrera historicamente com outros povos indígenas. Apesar disso, não podemos delimitar ainda o quanto a influência do PB repercute no Pykobjê-Gavião, tanto no que se refere aos usos quanto às estruturas linguísticas (THOMASON; KAUFMAN, 1988). E, sobretudo, não sabemos quais são as consequências que o (possível) aumento da exposição a um bilinguismo deixará no âmbito da formação cultural.

Já a alfabetização, ela tende a ocorrer nas escolas indígenas das aldeias, com atuação majoritária de professores não indígenas e missionários americanos. Como já salientamos, alguns poucos indígenas também passaram a contribuir para com o ensino formal, após receberem a oportunidade de cursarem módulos ou graduação de licenciatura intercultural, que são oferecidos por instituições públicas de Ensino Superior deste país.

Sobre o uso da segunda língua (doravante L2), muitos Pykobjê-Gavião falam - PB com relativa proficiência, basicamente devido à necessidade de contato (MATTOS E SILVA, 2004) com representantes de órgãos de proteção aos indígenas, vendedores e demais pessoas que movimentam serviços nas cidades próximas.

Sobre os mecanismos de trocas linguísticas, apesar de a escrita uniformizada Timbira ter sido aprovada em dezembro de $2003^{48}$ e de, na ocasião, contar com a anuência de representantes de seis dos sete povos Timbira, o que incluía membros do grupo Pykobjê-Gavião, a grafia adotada ainda é a missionária (Missão Novas

\footnotetext{
${ }^{47}$ Seria essencial desenvolver uma pesquisa sociolinguística sobre isso, pois o que colocamos aqui é apenas uma observação. Como não há ainda dados ou discussões, especificamente sobre esta temática, deixamos como proposta a estudos futuros.

${ }^{48}$ A grafia uniformizada Timbira já estava em discussão desde 1994, segundo Amado (2004, p. 06, 07).
} 
Tribos do Brasil $\left.^{49}\right)$, conforme citamos anteriormente. No que diz respeito à prática escrita, a grafia uniformizada (verificar Apêndice) não é conhecida e ainda não foi implantada em nenhuma das aldeias Pykobjê-Gavião ${ }^{50}$.

Ainda que os educadores, especificamente os indígenas, reconheçam que a grafia missionária apresenta algumas lacunas, uma vez que não estabelece uma relação constante entre som e grafema - o que, por sua vez, não se coloca como uma prerrogativa para um sistema de escrita vigorar -, ela é a vigente por duas razões fundamentais: (i) faltam materiais didáticos, que ensinem e apliquem a grafia uniformizada; (ii) os replicadores da escrita indígena (indígenas ou não indígenas), praticamente, desconhecem a existência da mesma. Tal situação evidencia que, embora a grafia Timbira tenha sido elaborada com embasamento teórico (assessoria das linguistas Flávia de Castro Alves e Rosane de Sá Amado) e sob uma égide democrática, podemos apontar falhas na transmissão desse conhecimento entre os Pykobjê-Gavião.

A importância ressaltada aqui de que seja desenvolvido um trabalho para repassar o uso da grafia uniformizada diz respeito à observação de que, a partir disso, pode-se pensar em ampliar o contato por escrito entre esses grupos ${ }^{51}$.

De todo modo, conforme já disse Langacker (1977, p. 66): "A língua é a fala e a competência linguística subjacente à fala. A escrita não é mais do que uma representação gráfica secundária da fala, a qual goza de certos privilégios." Privilégios estes, que podem e devem ser epistemologicamente questionados, ao considerarmos questões como a identidade.

Todavia, como já pontuamos antes, um traço marcante dos povos Timbira é a capacidade de se apropriar e ressignificar os dados culturais dos cöpẽ. Desse modo, com a escrita não poderia ser diferente. No dia a dia, a escrita tende a ser mais utilizada por eles para produzir cartas dirigidas aos cöpẽ. Contudo, o gênero carta recebeu nuances um tanto peculiares entre todos os sete povos Timbira (LADEIRA, 2001).

\footnotetext{
49 Para conhecer melhor o trabalho deste grupo missionário, sugerimos uma visita ao website: http://www.mntb.org.br. Acesso: 08/06/2016.

${ }^{50}$ Não sabemos como essa questão tem se apresentado em outros grupos Timbira. Assim, deixamos essa nota como uma possibilidade para pesquisas futuras.

${ }^{51}$ Um exemplo de troca escrita possível é a produção do site em língua Kaingáng: http://kanhgag.org/ (Acesso: 19/10/2016).
} 
Se para nós, as cartas e/ou bilhetes são utilizados, basicamente, na comunicação entre indivíduos distanciados espacialmente ${ }^{52}$, entre os Timbira, as cartas podem ser dirigidas aos cöpẽ que estão próximos, ao alcance dos olhos do enunciador do discurso. Então, será a carta a estabelecer uma distância, que não é espacial. Se a distância física existe, então, os Timbira preferem utilizar o telefone, que atualiza o sujeito da fala por meio da voz e, ao mesmo tempo, marca a distância física que realmente existe.

De qualquer forma, o objetivo de preservar a face do interlocutor solicitador é mantido, em caso de recusa. Ao se evitar o constrangimento e o ataque direto à face, abre-se margem para que este mesmo pedido possa ser re-elaborado em outra ocasião. Nesse jogo de sedução pela palavra, a figura do portador é de grande importância, pois o portador é a garantia de que a comunicação será realizada de maneira eficiente. Por isso, deve ser um sujeito por quem enunciatário e enunciador tenham empatia e confiança.

Assim, a partir do exemplo discutido acima, observamos que os Timbira não só se apropriaram da escrita em língua não materna, como também a ressignificaram em seu universo discursivo.

Apesar de reconhecermos que a escrita pode ser aprendida através do processo de alfabetização escolar (contexto formal), em grupos de discussão (contexto não formal) ou disparada por outras formas de exposição (contexto informal), devemos pontuar que a escrita em língua materna deveria ser assumida como um compromisso social do Estado para com as minorias étnicas. E, aqui, realçamos uma questão central: os direitos sociais, incluso o direito de uso pleno da língua materna, estão sujeitos a categorias sócio-históricas, que nos antecedem, como o é a identidade.

\subsection{Alfabetização e letramento: identidades em disputa}

Iniciamos este tópico assumindo que tanto as instituições escolares quanto as consequentes noções de sucesso (boa adaptação) e seu contraponto, o fracasso

\footnotetext{
${ }^{52} \mathrm{Na}$ nossa sociedade contemporânea, em decorrência da tecnologia trazida com o uso do computador e da internet, o gênero e-mail tem assumido o lugar dos gêneros carta e bilhete. Isso fala sobre duas questões: (i) nós, assim como os Timbira, estamos em processo de reelaboração dos gêneros discursivos da modalidade escrita da língua portuguesa; (ii) tendo observado (i), podemos indagar como os Timbira se adaptarão a partir da reelaboração já feita pelos cöpẽ, ocasiada pela inserção do instrumento computador/internet.
} 
(má adaptação), são instâncias social e historicamente criadas e perpetuadas para manter e sustentar o status quo ou, em outras palavras, uma classe portadora da identidade politicamente majoritária, conforme já discutido neste capítulo. Desse modo, a "ideologia do mérito, das aptidões de sucesso" (OLIVEIRA, 2001) atua para que essa engrenagem de favorecimento não se perca.

Patto (1996, p. 10) aponta como elementos fundamentais para compreender as dinâmicas da instituição escolar a dupla Revolução, com cenário na Europa Ocidental.

De um lado, assinala a autora, emergiu a Revolução política Francesa (17891792), com manifestações de caráter populista (ao que destacamos o protagonismo dos sans-culotte) e investimento no lema da "igualdade, fraternidade e liberdade".

De outra parte, destacou-se a Revolução industrial Inglesa, com marco na região de Lancashire, em 1780. Ao contrário da Revolução Francesa, a Inglesa foi impulsionada pela burguesia liberal, oriunda dos sistemas feudais e contraposta às versões monárquicas de poder. Dentre seus investimentos centrais, valeria destacar a inserção do caráter alienado do processo de trabalho, isto é, a separação entre trabalho e "objetos de uso", além da valorização dos "objetos de valor" e, com isso, a promoção de um distanciamento contínuo entre "burguesia" (proprietários dos meios de produção, que visam o acúmulo de capital) e "proletariado" (aqueles que ofertam a força de seus músculos ou cérebro para garantir a sobrevivência).

Conforme já discutimos, há um choque de expectativas e vivências, quando o Estado tenta inserir o indígena na lógica, que fundamenta as nossas atuais instituições de ensino. Mesmo que sejam respeitados elementos culturais, como o período de festas, o que está por trás dessa escola "aldeada" ainda é a reprodução da alienação do processo de ensino-aprendizagem, verificada nos modelos reprodutivistas de educação (SAVIANI, 1982). Essa lógica se opõe à "educação como processo comunitário" (MELIÀ, 1979), que vigora nas sociedades indígenas tradicionais.

Ainda sobre a escola reprodutivista, que marca o modelo ocidental, Oliveira (2001, p. 18) explica que a instituição escolar tende a cooptar e alienar todos os seus membros, incluso os docentes, tal que "a professora que silencia a criança é igualmente silenciada: sua voz se faz instrumento da fala do outro, a do autor da 
cartilha ou do livro didático". Isso, por sua vez, difere, radicalmente, da tradicional experiência indigenista, porque:

\begin{abstract}
Os educadores do índio têm rosto e voz; têm dias e momentos; têm materiais e instrumentos [...] para educar a quem vai ser um indivíduo de uma comunidade com sua personalidade própria e não elemento de uma multidão. A educação do índio, nesse sentido, não é geral e muito menos genérica. A educação do índio é menos parcial do que a nossa, aplicandose ao ensino a aprendizagem de modo a satisfazer às necessidades fisiológicas, como a criação de formas de arte e religião. (MELIÀ, 1979, p. 10)
\end{abstract}

Dado o cenário e suas forças em disputa pelo biopoder, propagado e mantido pela instituição escolar, Patto (1996, p. 17) afirma que o atual fracasso dessa instituição remonta ao fato de que a Revolução política Francesa perdera espaço para a Revolução industrial Inglesa e, como consequência da quebra dessas duas dimensões, o papel da escola passou a ser, cada vez mais, investido para formar a mão de obra necessária às demandas do capital. Dentre elas, a autora destaca a importância dos movimentos nacionalistas, que imbuíram à escola de propagar um "sentimento de pertencimento", forte o suficiente para assegurar as fronteiras estabelecidas outrora.

Então, dentre outras funções, caberia à instituição escolar fundar e fundamentar os pilares da identidade nacional, e, sobretudo, unificar dialetos na forma das nossas (atualmente aceitas e ensinadas) normas cultas da língua, com gramática prescritiva e formação de um público leitor.

Porém, como temos discutido até aqui, a formação da identidade nacional pode ser - e geralmente o é - entendida como o apagamento das identidades, que se mantêm pela alteridade com o padrão dominante.

Desse modo, mesmo que a Portaria Interministerial n 559/91 destaque 0 compromisso com uma organização sócio-histórica, capaz de garantir ao indígena os conhecimentos básicos para se posicionar criticamente frente à sociedade nacional e seja assegurado a essa população o direito de aprender em língua materna, o que tende a ocorrer é que "a língua indígena perde sua primazia, uma vez que os códigos da sociedade nacional são transmitidos pela língua nacional." (FILHO, 2006, p. 215).

A questão, portanto, que gostaríamos de destacar é a hipocrisia que subjaz quando o Estado afirma assegurar o direito às línguas indígenas maternas, porém 
se nega a alçá-las à posição de línguas nacionais, ou seja, relega as línguas indígenas e, consequentemente seus falantes, a um espaço secundário, no que concerne às disputas das esferas públicas.

Essa medida ratifica o que destacamos, no início deste capítulo, o indígena é levado a ocupar o espaço das identidades "que valem menos", no jogo do capital. Suas línguas e culturas podem ser toleradas como parte da identidade nacional afinal, a instituição escolar até se permite "comemorar" o famigerado Dia do Índio -, contudo, a identidade indígena se apresenta no cenário público muito mais como um apêndice nacional do que como uma identidade de direito. Nessa esteira, Silva (2000) discute:

\footnotetext{
$\mathrm{Na}$ perspectiva da diversidade, a diferença e a identidade tendem a ser naturalizadas, cristalizadas, essencializadas. São tomadas como dados ou fatos da vida social diante dos quais se deve tomar posição. Em geral, a posição socialmente aceita e pedagogicamente recomendada é de respeito e tolerância para com a diversidade e a diferença. (SILVA, 2000, p. 73)
}

Retomando Patto (1996), a autora ressalta que, por muito tempo, a instituição escolar sequer buscou manter a aparência de acolhimento para com as identidades, que reverberam a alteridade própria do capitalismo. Ou seja, a escola traz em sua história um afastamento proposital das classes populares, inclusive sem se posicionar no que diz respeito à identidade de minorias, como os indígenas. Nesse contexto, a educação e o acesso à mediação simbólica pela escrita eram um privilégio.

De maneira análoga ao que se verifica na produção do fracasso escolar, o analfabetismo serviu para assegurar a manutenção do status quo. Como consequência "apesar da vulgarização do livro e da ênfase na necessidade de uma língua nacional oficial, a imensa maioria da população mundial permaneceu analfabeta até por volta de 1870." (PATTO, 1996, p. 26).

Voltando ao percurso histórico, que nos traz à atual conjuntura política, foi com a ascensão do ideário da Revolução Inglesa que a instituição escolar passou a trabalhar em uníssono com as demandas do capital.

Diante do crescimento das cidades, a partir de 1870, ganharam mais força os sentimentos de medo e insegurança e, com isso, os investimentos nas "faxinas urbanas" e formação de espaços "apaziguadores" dos desajustados. Dentre eles, evidencia-se o hospital psiquiátrico, com o qual a pedagogia muito tem a dialogar. 
Pois, se por um lado, o hospital foi tomado como o espaço do alijamento social, por outro, a escola foi investida, pelo menos até a Primeira Grande Guerra (1914-1918), como um ambiente com "superpoderes" para proporcionar a paz social (PATTO, 1996, p. 27).

A partir da difusão da crença de que a instituição escolar poderia atuar como um mecanismo de controle dos corpos (produção de "corpos dóceis"), o indígena foi inserido pelo Estado na roda das discussões sobre educação. Afinal, os corpos dos pobres e das minorias precisavam ser apaziguados.

À ocasião, ganhou força a ideia do "mérito pessoal" e a crença na liberdade individual do homem racional e com retidão moral. Patto (1996, p. 20) designa, então, como self-made man, em referência a um termo de uso corrente nos Estados Unidos, desde o século XIX: "Em termos individuais, o self-made man, racional e ativo, representava o cidadão ideal”, a ser moldado pela/na instituição.

São por tais pressupostos que se difundem discursos muito corriqueiramente produzidos e reforçados, como o de que "abrir escolas é fechar cadeias". O que tais dizeres do senso comum tomam como pano de fundo é a percepção de que a escola teria uma função preventiva contra a loucura e o crime, de uma tomada individual rumo ao objetivo mais amplo, de "curar' o inconsciente primitivo do povo brasileiro" (PATTO, 2012, p. 154).

Contudo, tal "cura" não se volta de forma igualitária, tendendo a assumir como alvo privilegiado mais alguns grupos sociais do que outros. Desse modo, muitas ciências têm sido usadas ora para ratificar ora para prevenir/evitar/corrigir "a crença na incompetência das pessoas pobres" (PATTO, 1996, p. 50), servindo, assim, como mantenedora da teoria da carência cultural, que assume, de partida, a inferioridade de indígenas, negros e mestiços. Por isso, cabe-nos questionar o que o poder público tem entendido como oferta de uma "educação diferenciada".

Como dissemos no início deste tópico, a escola tende a refletir as contradições da sociedade em que se situa, atuando como mantenedora e promotora das ideologias dominantes, como explica Oliveira et al. (2001):

Convém, portanto, ao statu quo naturalizar o fracasso escolar para legitimar a seletividade, sobretudo atribuindo-o às "deficiências" do aluno ou à "incompetência e descompromisso" dos professores. (OLIVEIRA et al., 2001, p. 29) 
Nesse sentido, a alfabetização, que pode ser entendida como um processo com vias à incompletude, é estruturada em "fases" "53, que diriam respeito à aquisição de habilidades fatiadas e graduais, despidas das experiências oriundas do campo dos afetos (assumindo afetos sob a perspectiva espinosiana) e alijadas de formação política, essencial para a formação da criticidade.

Pensando na incompletude do processo de alfabetização, que é deixada de lado quando a aprendizagem passa a ser institucionalizada, Tfouni (2006, p. 15) explica que:

[...] de um ponto de vista sociointeracionista, a alfabetização, enquanto processo individual, não se completa nunca, visto que a sociedade está em contínuo processo de mudança, e a atualização individual para acompanhar essas mudanças é constante. (TFOUNI, 2006, p. 15)

Giddens (1991) afirma que, por sua vez, isso reflete um mecanismo próprio da modernidade, na qual a língua (falada ou escrita) não pode mais ser assumida como um instrumento para a mediação simbólica, sem que o próprio instrumento seja colocado em uso para promover um posicionamento crítico acerca da condição social, que se apresenta como texto, conforme discutimos no início deste capítulo. Nas palavras do autor:

A modernidade é constituída por e através de conhecimento reflexivamente aplicado, mas onde, ao mesmo tempo, não podemos nunca estar seguros de que qualquer elemento dado deste conhecimento não será revisado. (GIDDENS, 1991, p. 46)

Desse modo, se assumirmos que um dos produtos da alfabetização, a escrita, advém de um processo sócio-historicamente engendrado, sujeito, portanto, às interferências político-econômicas, podemos depreender que a escrita (ou quem pode escrever) tende a refletir as relações de poder e dominação, que algumas identidades promovem sobre outras. $E$ isso fica muito evidente, quando nos voltamos às redações produzidas pelos indígenas.

Conforme Tfouni (2006) afirma, a função social da escrita esteve mais vinculada à necessidade de ocultar do que a de difundir informações entre os povos.

\footnotetext{
53 Cabe-nos fazer aqui um adendo. Embora, na escola de Governador, tenhamos obsevado seriação das competências, é comum que o fator "idade", vinculado a uma percepção temporal de desenvolvimento, não seja preponderante, de modo que ainda é aceito que diferentes faixas etárias possam ocupar a mesma série. No entanto, com a inserção do EJA, essa tem sido uma questão problemática para professores e equipe pedagógica.
} 
Desse modo, quando as políticas públicas deixam de reconhecer as línguas indígenas como línguas nacionais - logo, passíveis de terem documentos oficiais escritos -, o que se está promovendo é a perspectiva de que os indígenas do Brasil precisam se esforçar para ter acesso aos seus direitos. Ou seja, eles devem aprender a língua (falada e escrita) do colonizador.

Essa lógica se assenta no ideal de que pessoas desiguais teriam as mesmas condições de atingir a contemplação das benesses, pressuposto para a manutenção da burguesia liberal no poder e, portanto, de um Estado que adota políticas que beneficiam mais uns grupos do que outros.

Sobre a lógica da exclusão, calcada em um ideal de homem, Oliveira et al. (2001, p. 09) criticam a manutenção de uma "ideologia do mérito, das aptidões de sucesso", apontando que o fracasso escolar/profissional, por ser um construto social e historicamente engendrado, antecede a entrada do sujeito nas instituições da vida pública, conforme viemos discutindo até aqui.

Tendo visto que há grupos sociais mais suscetíveis do que outros à interferência da escola e suas práxis, retomamos que, assim como a instituição escolar foi produzida a partir de um campo de forças, social e historicamente em disputa, o fracasso escolar também o fora (e o é, uma vez que somos produtos e produtores de nosso meio). Isso significa que os "fracassados" trazem à tona muito mais elementos sociais para análise do que caracteres referentes à sua formação moral, retidão de caráter e/ou capacidades subjetivas para empreender, via racionalidade. Permite, por fim, questionar quais são as perspectivas e ideologias, com as quais os saberes buscam emular nos campos pedagógicos. Ou seja, a quem respondem, o que respondem e, sobretudo, por que respondem?

Nesse sentido, Alencar (2006) reflete acerca da importância de que a linguística se posicione como um campo pedagógico, com prática transformadora sobre a sociedade. Desse modo, a autora afirma que as práticas discursivas podem atuar como fatores perpetuadores das relações de dominação e injustiças sociais, se as ideologias não forem abordadas mediante à desnaturalização das ideologias dominantes. Em suas palavras: 
traz uma nova possibilidade para a pesquisa linguística: esta se tornar uma engajada pesquisa com sujeitos engajados em uma transformação social. (ALENCAR, 2006, p. 57)

Essa discussão se insere em uma problemática mais ampla, que diz respeito às escolhas políticas que uma instituição escolar pode fazer. Por exemplo, quando os Parâmetros Curriculares Nacionais (PCN) colocam como principal unidade de análise o texto, ao invés de categorias isoladas, a política pública está dizendo que considera mais importante que o aluno seja capaz de compreender o todo (incluso as identidades em disputa), ao invés de se ater a fragmentos categorizados da vivência linguística. Sobre isso, Coroa (2006) discute:

\footnotetext{
Uma proposta que privilegia o ensino da unidade texto, como a dos PCN, compromete-se com um corpo de "verdades teóricas" que implicam o redirecionamento tanto da postura do professor quanto de sua prática em sala de aula, porque entram em ação novos conceitos, novos relacionamentos, além de "novos" conhecimentos. [...] Assim compreendido, o texto é uma unidade significativa que se constitui historicamente e, nesse processo, incorpora os papéis sociais do contexto e dos interlocutores. (COROA, 2006, p. 145-146)
}

Ser capaz de entender um texto demanda dialogar com outra competência, o letramento. Não se deve considerar letramento como sinônimo de alfabetização, tampouco de escolarização, pois mesmo indivíduos analfabetos estão expostos a graus de letramento. Por exemplo, em estudos com adultos, Tfouni (1984; 1986 apud TFOUNI, 2006, p. 26-27) observou que "os não-alfabetizados têm capacidade para descentrar seu raciocínio e resolver conflitos e contradições que se estabelecem no plano da dialogia."

Pensando sobre o olhar da etnolinguística, considerar a unidade texto alinhado a uma percepção de que o letramento é uma importante ferramenta teórica, pode dizer algo sobre as potências comunicativas da comunidade de fala, para além da estruturação categórica da língua ou da seriação do processo de alfabetização (HYMES, 1972, p. 36).

Conhecer a condição histórica e social de um povo significa, portanto, reconhecer a língua como uma dentre outras funções sociais, a alfabetização como um dentre outros mecanismos de poder, mas, certamente, o letramento e a escrita (em língua materna) como direitos sociais. 


\section{Linguagem e sociocognição}

Gostaria de convencer meu leitor de que o problema central não é saber se o mundo está pronto, mobiliado por alguma divindade, cabendo-nos captálo conceitualmente, ou se o mundo tem uma ordem dependente do mobiliário de nossas mentes repletas de verdades a priori, mas sim como a ordem - seja qual for - é percebida, construída, comunicada e utilizada. Acredito que a ordem de nossos conhecimentos e das instituições que os suportam não é uma ordem natural, mundana. É uma ordem essencialmente cognitiva e interativamente semiotizada: uma ordem histórica e sócio-interativa. (MARCUSCHI, 2005, p. 50)

Antes de iniciarmos as discussões sobre as relações entre a sociocognição e as perspectivas teóricas em diálogo com a linguística, é essencial esclarecermos que tanto em um campo quanto em outro há variados caminhos para compreendermos o que se passa na mente de uma pessoa, quando ela começa a inferir o que o mundo e seus pares podem lhe ofertar como resposta(s), diante de uma condição social determinada. Em outras palavras, apesar de ser um terreno amplo, o olhar para a sociocognição da linguagem nos permite analisar como as pessoas com desenvolvimento típico e atípico conseguem dar conta da psicologia popular (folk psychology).

A esse "constructo nascido da psicologia cognitiva e que se refere à capacidade de atribuir estados mentais para si mesmo e para os outros" (CAIXETA; CAIXETA, 2005, p. 13) se convencionou denominar "teoria da mente" (theory of mind, doravante ToM).

ToM é uma área da sociocognição e versa, basicamente, sobre desejos, crenças e conhecimentos de si, do outro e do mundo. A partir dessa capacidade é que podemos discutir sobre o lugar que a linguagem assume na cognição humana.

Então, se retomarmos o esquema proposto no capítulo 2, por Dik (apud Neves, 2004, p. 19), podemos entender que ToM emerge como uma competência, que diz sobre a "intenção" do falante e, a partir disso, pode antecipar a "interpretação" do destinatário, seja simulando que o eu é o outro seja por meio de um "set de práticas e convenções culturais e sociais" (JOU; SPERB, 1999, p. 291). Para facilitar a visualização, copiamos abaixo a imagem: 


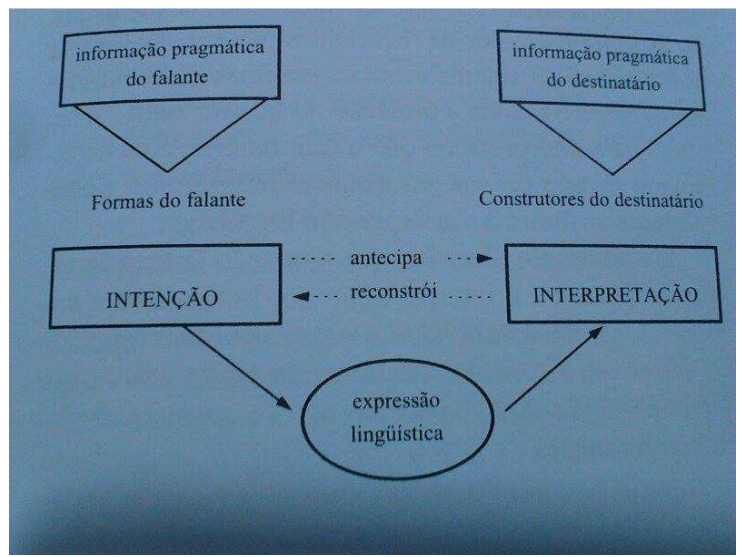

Modelo de interação verbal, de Dik (DIK, 1989ª , p. 8-9, apud NEVES, 2004, p. 19)

Contudo, como explicação para a gênese dessa importante habilidade, há teóricos que assumem que ToM seria uma capacidade inata, o que coaduna com a proposta linguística da teoria gerativo-transformacional, igualmente discutida no capítulo 2.

No que diz respeito aos estudos iniciais sobre a relação entre corpo e expressão de língua, Bear; Connors; Paradiso (2008) nos conta sobre o papel que, por muito tempo, a língua assumiu como "órgão da linguagem":

\begin{abstract}
Durante os impérios grego e romano, era comum se pensar que a língua controlava a fala, e que distúrbios da fala originavam-se na boca, e não no encéfalo. Se uma lesão na cabeça resultava em perda da fala, o tratamento envolvia gargarejos especiais ou massagens na língua. Por volta do século $\mathrm{XVI}$, foi sendo observado que uma pessoa poderia sofrer um prejuízo da fala sem a paralisia da língua. Apesar desse avanço, no entanto, os tratamentos ainda incluíam procedimentos para cortar a língua, retirar sangue e aplicar sanguessugas. (BEAR; CONNORS; PARADISO, 2008, p. 618)
\end{abstract}

Com o desenvolvimento das ciências biológicas, a língua deixou de ser o ponto central para pensar a linguagem. Aos poucos, os pesquisadores buscaram como fonte de explicação o cérebro, particularmente o encéfalo, e, nos dias atuais, podemos falar sobre a interferência da manipulação hormonal.

De todo modo, os adeptos da visão de que ToM seria uma capacidade inata e vinculada a um órgão biologicamente determinável têm investido na observação de sujeitos com desenvolvimento atípico ou lesionados.

Como exemplo de desenvolvimento atípico, muitos estudos têm se voltado a pessoas portadoras de transtornos do espectro autista (TEA). De fato, esses sujeitos 
podem apresentar maiores dificuldades em ToM. Desse modo, a hipótese aventada é que isso se daria em decorrência de um déficit neurológico inato, que incapacitaria o sujeito em uma das esferas da cognição/linguagem.

As perspectivas, que assumem ToM como uma capacidade inata e específica à espécie humana, tendem a buscar respaldo em outros campos científicos, como a neuropsicologia e a neurociência, sobretudo observando sujeitos com desenvolvimento atípico ou lesionados.

A neuropsicologia assume como ponto de análise central a existência de um substrato fisiológico, que permitiria a formação de ToM adequada, segundo um funcionamento típico.

As pesquisas nesta área, em geral, estão focadas em analisar como alterações do aparato biológico implicam em alterações cognitivas referentes ao contato com o mundo, com a própria cognição e com o outro. Para empreender tais estudos, é comum que os pesquisadores desta linha voltem o olhar para indivíduos com desenvolvimento típico, mas que, em dado momento, sofreram alguma lesão encefálica. Então, as análises dispostas se focam na observação descritiva de desempenho frente a tarefas pré-determinadas e/ou previstas.

Em suma, a perspectiva neuropsicológica se dá a partir de uma escala de normalidade, que demanda capacidades, passíveis ou não de serem desempenhadas. E a explicação para os desempenhos se correlaciona com as capacidades (inatas) oriundas do biológico, o que inclui desde a neuromorfologia até os estudos mais recentes sobre genética e disposição hormonal.

Já a neurociência surgiu da proposta de descrever o sistema nervoso, enquanto emaranhado celular complexo. Atualmente, entende-se que o encéfalo é o principal responsável biológico pela diferença entre ser humano (homo sapiens sapiens) e demais animais - incluso outros primatas - e, que tal diferença poderia ser percebida, dentre outros aspectos, pela capacidade de introspecção, ao que se poderia destacar a linguagem. Todavia, Caixeta; Caixeta (2005) ressalta que isso não é uma verdade, pois não se deve pensar em introspecção, linguagem e ToM como um fenômeno tudo-ou-nada:

Vários estudos sugerem que alguns primatas não-hominídeos mais evoluídos, como o chimpanzé, o bonobo e o gorila, apresentam algum grau 
de Teoria da Mente, muito mais precário, obviamente, que o que se apresenta na espécie humana (Gallup, 1970; Povinelli \& Preuss, 1995; Heyes, 1998). Assim sendo, pode-se deduzir que a Teoria da mente não é entendida como um fenômeno tudo-ou-nada, isto é, uma habilidade que existe ou inexiste. Antes, é encarada como uma aquisição evolutiva que foi progressivamente sofrendo os processos de lapidação pelas forças da pressão seletiva. (CAIXETA; CAIXETA, 2005, p. 18)

Os estudos neurocientíficos para compreensão da linguagem em intersecção com os domínios do encéfalo ainda têm muito a avançar, contudo vale destacar que já se afastaram bastante de seus primórdios, em que vigorou um acentuado localizacionismo.

A princípio, percebeu-se que limitações funcionais poderiam estar diretamente relacionadas a lesões ou doenças (pontuais ou degenerativas) do sistema nervoso. Assim, passou-se a investigar as correlações entre áreas do cérebro e dadas funções cognitivas, dentre elas a linguagem.

Com tal perspectiva, no final do século XIX, Broca e Wernicke, cada qual com seus experimentos, afirmaram ser possível estabelecer uma relação entre danos cerebrais e a detecção de déficits na faculdade da linguagem ${ }^{54}$.

Os estudos em neurociências foram facilitados a partir de 1970, quando houve avanços no desenvolvimento de técnicas para a obtenção de imagens encefálicas, tais como a tomografia computadorizada axial (TCA) e a ressonância magnética (RM). Essas mudanças significaram poder enxergar melhor a maquinaria em uso, ou seja, biologicamente ativa. Além disso, a ciência, recentemente, apresentou uma contribuição importante, vinculada ao uso de células-tronco para tratamentos específicos, embora não se tenha ainda o devido controle de tal prática.

Apesar de todos estes avanços, ainda falta muito para compreendermos todas as potencialidades que o cérebro humano apresenta. Tampouco, sabemos dizer como a linguagem verbal e não verbal se processa, exatamente.

Com o tempo, percebeu-se que os modelos de processamento linguístico focados nas áreas de Broca (produção, o indivíduo entende o que é solicitado, mas é incapaz de produzir respostas) e Wernicke ou córtex auditivo secundário

\footnotetext{
${ }^{54}$ Atualmente, sabemos que tais déficits podem ser amenizados através de estímulos adequados, pois o cérebro é dotado de neuroplasticidade. E isso tem se mostrado essencial, sobretudo em casos de acidente vascular encefálico (AVE).
} 
(recepção, o indivíduo consegue produzir respostas e/ou falas complexas, mas não entende o que lhe é proposto) não satisfaziam os casos encontrados, o que alavancou a hipótese conexionista para a linguagem, de acordo com a qual a linguagem só poderia ser satisfatoriamente produzida e recebida, se todas as áreas se correspondessem de modo harmonioso.

Alinhado a essa visão, Givón (1995, p. 421) afirma que é equivocado relacionar o funcionamento de determinadas áreas do cérebro a uma competência essencialmente funcional, que é a linguagem, bem como o seria se o mesmo fosse postulado no que concerne à apreciação da dança ou da música. Em suas palavras, não se pode dizer que há perda de capacidade gramatical ou perda de capacidade lexical, sem considerar que essas duas competências emergem juntas nos usos linguísticos:

\begin{abstract}
Para começar, a gramática é extremamente sensível à semântica lexical, especialmente no que diz respeito às características classificatórias mais genéricas de organização conceitual: concretude, animacidade, agente, humano, contável e outros traços classificatórios dos nomes; telicidade, intencionalidade, aspecto, tempo, modalidade e outros traços classificatórios dos verbos; sensorial, espacial, valorativo, emotivo e outros traços classificatórios dos adjetivos.

Além disso, morfemas gramaticais e derivacionais se formam diacronicamente a partir de lexemas. No princípio de uma gramaticalização, a mesma forma fonética é frequentemente usada de duas formas, para codificar ou um conceito lexical ou uma função gramatical. Aí reside uma possibilidade real, assim, de que a morfologia mantenha sua representação na semântica lexical, enquanto estabelece conexões com o módulo da gramática. ${ }^{55}$ (GIVÓN, 1995, p. 421, tradução nossa)
\end{abstract}

Nesse ínterim, as pesquisas do psicólogo Michael Gazzaniga (1970) tiveram grande contribuição. Gazzaniga (1970) trabalhou com pacientes que tiveram o corpo caloso rompido em algum grau (split-brain) e, a partir disso, estudou a percepção de tais indivíduos. Sua contribuição evidenciou que existe lateralização vinculada à

\footnotetext{
${ }^{55}$ Texto original: "To begin with, grammar is extremely sensitive to lexical semantics, especially to the more generic classificatory features of conceptual organization: concreteness, animacy, agency, humanity, countability and other classificatory features of nouns; telicity, intentionality, aspectuality, temporality, modality and other classificatory features of verbs; sensory, spatial, valuative, emotive and other classificatory features of adjectives.

Further, grammatical and derivational morphemes arise diachronically from lexical words. At the outset of such grammaticalization, the very same phonetic form is often used in a double capacity, to code either a lexical concept or a grammatical function. There remains a real possibility thus that morphology retains its representation within the semantic lexicon while establishing connections to the grammar module."
} 
linguagem, e alguma dominância da área frontal, mas que, apesar disso, o encéfalo é plenamente capaz de se reorganizar, de modo que seria equivocado supor afasia de Broca ou afasia de Wernicke pura.

Todavia, ainda que se partisse da percepção teórica de que ToM decorreria de um mecanismo biológico inato, a aquisição da linguagem, via comunicação verbal - o que inclui elementos pragmáticos, tais como a preocupação com a estética da recepção -, considera a capacidade de se comunicar como uma relação, isto é, demanda um receptor.

Ao contrário do que é discutido na psicolinguística de adaptação, o enfoque não está na capacidade de negociar e adaptar os conteúdos linguísticos e paralinguísticos, mas na performance adotada frente a um estímulo, em que regras (sociais e linguísticas) são chamadas por um locutor e, quão melhor forem atendidas pelo falante, tanto mais desenvolvido está este indivíduo em sua capacidade comunicativa.

Então, se há pesquisadores apostando que ToM seria uma capacidade inata e própria à espécie humana, há também quem afirme que ToM se trataria de uma capacidade desenvolvida.

Desenvolvimentistas e inatistas não se colocam, a princípio, como opositores, pois ambos concordam com a importância do aparato biológico no desenvolvimento, inclusive no que se refere à aquisição de linguagem.

Como evidência desta proposta, ressalta-se que crianças com desenvolvimento típico apresentariam ToM em um nível bastante rudimentar (exemplo, bebê fixando olhar), que poderia ser aprimorado, à medida que houvesse o desenvolvimento de outras capacidades.

No que concerne especificamente à linguagem, por sua vez, algumas pesquisas levantaram a hipótese de que, em Inglês, as crianças passam a utilizar itens lexicais com conteúdo psicológico, por volta dos dois anos, complexificando seu uso com o passar do tempo. E, assim, seguem seu desenvolvimento, rumo à compreensão de crenças falsas, por volta dos quatro anos (SOUZA, 2006, p. 391). Desse modo, o que diferiria o adulto de uma criança seria, essencialmente, o desempenho, já que os adultos teriam tido mais tempo para se desenvolver do que as crianças. 
Sobre a importância das línguas aprendidas pelas crianças na manutenção/transmissão/recriação dos elementos culturais, ressaltamos:

\begin{abstract}
A língua usada pela criança e para a criança nas interações sociais raramente tem sido um recurso de informação na socialização. Como uma consequência, nós sabemos pouco sobre o papel que a língua representa na aquisição e transmissão de conhecimento sociocultural. Nem as formas, as funções ou o conteúdo da mensagem linguística foram documentados ou examinados de modo a entender como eles organizam e são organizados pela cultura. ${ }^{56}$ (OCHS; SCHIEFFELIN, p. 263, tradução nossa)
\end{abstract}

Assumindo a perspectiva vigotskiana, podemos dizer que a linguagem atua como um instrumento de mediação. É, ao mesmo tempo, simbólica e gramatical, ou seja, fala do mundo em que o sujeito se estrutura como ente cultural (processos maturacionais culturais), além de denotar a compreensão das regras próprias da língua em uso (processos maturacionais biológicos).

A perspectiva dada acima não se apresenta apenas sob o olhar vigotskiano.

$\mathrm{Na}$ teoria lacaniana, por exemplo, assinala-se que a linguagem é o que dá sustentação simbólica ao sujeito. Desse modo, o esperado é que, a partir da primeira fase do Édipo ${ }^{57}$, a criança seja capaz de depreender os símbolos do mundo (LOURENÇO, 2005). E, ao final do Complexo de Édipo, tenha adquirido a "metáfora paterna". Assim, o Nome-do-Pai entra em substituição ao falo enquanto objeto de desejo da mãe, para onde o olhar da criança estava voltado, por sua vez, na primeira fase do Complexo de Édipo.

Em termos práticos, se o desenvolvimento se deu dentro do esperado ${ }^{58}$, a criança deve ser capaz de entender que podemos colocar vários significantes no lugar daquilo que desejamos. Para Lacan, ainda, o desejo nunca será alcançado, mas representado por demandas, que são essencialmente sociais, como portar dinheiro, poder e beleza, por exemplo.

Além disso, na teoria lacaniana, as regras estruturantes da língua remetem aos mecanismos de funcionamento do Outro, de modo que é importante que o

\footnotetext{
${ }^{56}$ Texto original: "The language used both by children and to children in social interactions has rarely been a source of information on socialization. As a consequence, we know little about the role that language plays in the acquisition and transmission of sociocultural knowledge. Neither the forms, the functions, nor the message content of language have been documented and examined for the ways in which they organize and are organized by culture."

57 Assim como Vigotski, Lacan não trabalha com a noção de um tempo cronológico previsto para o desenvolvimento. Sua teoria se baseia na perspectiva de tempo lógico, por isso é aceito que haja o investimento no "corte de sessão", quando ocorre a prática clínica.

${ }^{58}$ Quando ocorre uma falha nesta estruturação simbólica, diz-se que houve uma "foraclusão do Nome-do-Pai".
} 
indivíduo reconheça e busque seguir essas regras, assinalando que ele é capaz de depreender que o Outro é castrado. Ou seja, o sujeito neurótico entende que há regras e que elas devem ser seguidas para falar e ser compreendido adequadamente pelo outro, assinalando pelo discurso a impossibilidade de viver sem limites.

Já na perspectiva sócio-histórica, Souza (2010) discute que a capacidade de classificação e discriminação entre sons, "palavras", "não palavras" e categorias gramaticais de uma língua amadurece com o desenvolvimento ontogenético da criança e, também, mediado pela fala da mãe, denominada classicamente como motherese $^{59}$ (mamanhês) e, em estudos mais recentes, como infant-directed speech (fala voltada à criança).

Então, o interlocutor privilegiado da criança é responsável por fornecer os símbolos com os quais ela precisa operar para se comunicar satisfatoriamente. Assim, "as mães, ao conversarem com seus filhos, estão primordialmente tentando engajá-los no diálogo e não apenas ensinando-lhes regras gramaticais" (PESSÔA; SEIDL-DE-MOURA, 2010, p. 40). Isso diz sobre a importância da comunicação como veículo de interação, conforme discutíamos no início deste capítulo.

Voltando às propostas para entender ToM, evolucionistas ampliam as proposições dos neuropsicólogos e afirmam ser ToM uma especificidade mapeável filogeneticamente. Segundo esta percepção teórica, tal capacidade teria permitido, dentre outras coisas, a sobrevivência da espécie, uma vez que predizer o comportamento do predador, adequadamente, seria um fator que ampliaria a possibilidade de transmissão genética. Ou seja, ToM poderia ser apontada como uma capacidade adaptável da espécie e que, por ter sido útil no desenvolvimento, foi não somente passada às gerações seguintes, como tem sido aprimorada no curso da espécie.

Nessa linha, Givón (1995) apresenta uma hipótese acerca do desenvolvimento filogenético da capacidade linguística no homem. Segundo este autor, a capacidade humana seria, simultaneamente, lexical e gramatical porque teria evoluído a partir de um sistema de comunicação viso-gestual, em que é

\footnotetext{
${ }^{59} \mathrm{O}$ termo motherese tem sido amplamente criticado por enfocar a figura da mãe como a principal responsável pelo desenvolvimento linguístico da criança. Tal olhar reforça a manutenção do "mito da maternidade", muito bem discutido por Elizabeth Badinter no livro Um amor conquistado: o mito do amor materno.
} 
preciso, portanto, simbolizar os itens e ordená-los para que o interlocutor receba essa comunicação:

\begin{abstract}
Minha tese central - que a neurologia de apoio específico para o processamento da linguagem humana é uma consequência evolutiva do sistema de processamento de informação visual - não é, estritamente falando, novidade. Em particular, a minha conclusão de que o código humano lexical começou sua evolução como um sistema icônico visogestual - foi antecipada por muitos antes (...). O que pode ser novo é a gama de fatos, até então, díspares que se coadunam em um relato coerentemente unificado, uma vez que a hipótese central seja adotada. ${ }^{60}$ (GIVÓN, 1995. p. 394, tradução nossa)
\end{abstract}

Pensando ainda na cognição da linguagem, alguns autores postularam acerca da seriação do desenvolvimento. Sendo este previsto e, portanto, passível de predição, houve o crescimento da psicologia cognitiva, cujos nomes mais proeminentes são Piaget, Astington e Olson.

Desse modo, Jean William Fritz Piaget, suíço, biólogo de formação e, posteriormente, professor de Psicologia pela Universidade de Genebra, propôs um modelo conceitual acerca da formação da inteligência, a se dar ao longo do desenvolvimento, ao que denominou Epistemologia Genética.

A Teoria Epistemológica Genética aposta, portanto, que as estruturas formadoras da inteligência, observável em estágios de desenvolvimento cognitivo (como dispostos na imagem abaixo, Imagem 3), seriam decorrentes de desequilíbrios, que levariam a assimilações e a acomodações.

\footnotetext{
60 Texto original: "My central thesis - that the supportive neurology specific to the processing of human language is an evolutionary outgrowth of the visual information-processing system - is not strictly speaking novel. In particular, my conclusion that the human lexical code began its evolution as an iconic visual-gestural system - has been anticipated by many before (...). What may be novel is the range of hitherto disparate facts that fall together into a unified coherent account, once the central hypothesis is adopted."
} 
Tabela 1 - Descrição dos estágios do desenvolvimento cognitivo.

Fonte: (Piaget, 1967).

\begin{tabular}{c|c|c}
\hline Estágio & $\begin{array}{c}\text { Faixa } \\
\text { etária }\end{array}$ & Características \\
\hline Sensório-motor & $0-2$ anos & Evolução da percepção e motricidade \\
\hline Pré-operatório & $2-7$ anos & $\begin{array}{c}\text { Interiorização dos esquemas de ação, } \\
\text { surgimento da linguagem do } \\
\text { simbolismo e da imitação deferida. }\end{array}$ \\
\hline $\begin{array}{c}\text { Operatório } \\
\text { Concreto }\end{array}$ & $7-11$ anos & $\begin{array}{c}\text { Construção e descentração cognitiva; } \\
\text { compreensão da reversibilidade sem } \\
\text { coordenação da mesma; classificação, } \\
\text { seriação e compensação simples }\end{array}$ \\
\hline Operatório & $\begin{array}{c}\text { Acima de } \\
\text { Formal }\end{array}$ & $\begin{array}{c}\text { lógicas matemóntimento das operaços e infralógicas, da } \\
\text { compensação complexa (razão) e da } \\
\text { probabilidade (indução de leis) }\end{array}$ \\
\hline
\end{tabular}

As assimilações, segundo a teoria piagetiana, ocorrem quando informações são incorporadas a estruturas pré-existentes. E podem ser de três tipos: assimilação generalizadora, assimilação discriminante e assimilação recíproca. Já as acomodações modificam as estruturas/esquemas pré-existentes ou criam novas estruturas/esquemas, a fim de dar conta de dados dispostos pelo meio (histórico e social), que levaram, por sua vez, ao desequilíbrio inicial.

No que tange à problemática da linguagem, Abreu et al. (2010) avaliam:

\begin{abstract}
A ênfase está, portanto, na construção, ou melhor, na reconstrução dos caminhos pelos quais o indivíduo evoluiu de um estado inicial pré-linguístico até um determinado estado atual, onde é amplamente capaz de um formalismo linguístico. Logo, é uma teoria estruturalista na qual o conhecimento é um processo se estruturando e não um estado já cristalizado; e nesse sentido é uma teoria realista, propriamente em oposição seja ao empirismo seja a um racionalismo idealista, a priori de tipo kantiano [...] (ABREU et al. 2010, p. 364)
\end{abstract}

Sendo igualmente uma teoria realista e não empirista, a partir da década de 1970, a Psicologia foi bastante influenciada pelos estudos da teoria gerativotransformacional. Assim como propagado pelos evolucionistas, Chomsky trabalha com a ideia de que a linguagem se estrutura a partir de um aparato biológico, isto é, um "órgão da linguagem". Seria este a possibilitar (ou não) o desenvolvimento seriado das estruturas linguísticas, como discutimos no capítulo 2.

Chomsky, assim como Piaget, formula níveis previstos para 0 desenvolvimento cognitivo, estando preferencialmente atento ao que se refere à aquisição da linguagem. Para este autor, as crianças com desenvolvimento típico seriam capazes de adquirir as regras das estruturas linguísticas antes de ter 
condição de, por exemplo, desempenhar adequadamente os usos previstos em seu grupo social. Como exemplo de tal proposição teórica, Chomsky apresenta o caso da regularização verbal.

Se tomarmos para análise uma língua como o PB, um bom exemplo de regularização verbal, a oferecer pistas acerca de uma formulação de regras e estruturas da língua-alvo, seria o uso de "fazi" (pretérito perfeito de "fazer"), bastante recorrente na fala de crianças pequenas. Elas podem se ver dizendo, em um primeiro momento:

_Mamãe, fazi xixi.

E, apenas adiante, serão capazes de entender que "fazer" se trata de um verbo irregular, por isso não segue as mesmas regras de conjugação de outros itens, pertencentes à segunda conjugação (final em -er), tal como "comer" (comi) e "beber" (bebi).

Desse modo, Chomsky investiu boa parte de seu fôlego em propor esquemas (por vezes, arbóreos), que pudessem dar conta das estruturas internas da cognição. Esse campo se afastou do estruturalismo ortodoxo/clássico, ao assumir que as estruturas previstas não buscariam apenas descrever a língua tal qual se apresenta no mundo, mas antes possibilitar um olhar estruturado para o desenvolvimento da cognição, sobretudo no que se refere ao aspecto linguístico. Como consequência, há maior investimento em uma teoria explicativa daquilo que autor denomina biolinguística.

Sob tal perspectiva, portanto, a atenção não está voltada para a descrição amiúde das línguas particulares. O objetivo é mais amplo e, como tal, provoca o linguista no sentido de contribuir para a formulação de uma gramática universal (GU). Sobre a GU, o autor esclarece:

\footnotetext{
O estudo da gramática universal, assim entendida, é um estudo da natureza das capacidades intelectuais humanas. Tenta formular as condições necessárias e suficientes a que um sistema deve satisfazer, para qualificarse como uma língua humana potencial, condições essas que não são acidentalmente verdadeiras das línguas humanas existentes, mas antes estão arraigadas na humana "capacidade de linguagem", e assim constituem a organização inata que determina o que conta como experiência linguística e qual conhecimento da linguagem surge, com base nessa experiência. (CHOMSKY, 2008, p. 64)
} 
Além de inatistas e desenvolvimentistas, vale destacar a percepção oriunda do encontro da Psicologia com as teorias interacionistas do desenvolvimento da criança.

Sob tal perspectiva teórica, tomam como ponto de partida os desenvolvimentistas, porém ampliam seus pressupostos. Assumem, dentre outras coisas, que a interpretação do mundo, das pessoas e da própria subjetividade está intimamente relacionada com a capacidade de construir representações, utilizando para isso os recursos cognitivos disponíveis na espécie, tais como memória (de curta ou de longa duração) e capacidade de aprendizagem.

Haveria, então, um caminho da representação primária (bebê faria uma representação direta com o mundo, via percepção), para a secundária (um pedaço de pau pode significar um carrinho, em determinada brincadeira) e, por fim, chegarse-ia à capacidade de meta-representação (característica da brincadeira de "faz de conta", em que se objetiva realizar representações de representações). É, principalmente, nessa linha que encontramos as discussões referentes à recepção e produção de usos linguísticos.

Por fim, podemos citar os culturalistas, que discutem a importância do social e cultural no desenvolvimento da teoria da mente. No que se relaciona às pesquisas em temas de linguagem, podem ser associados aos debates propostos por SapirWhorf.

Para esses pesquisadores, havia "a ideia de que cada língua, pertencente a uma determinada cultura, molda a forma como membros de sua cultura e comunidade linguística interpretam o mundo" (SOUZA, 2006, p. 193).

Para conferir um panorama geral das disputas apontadas nesse campo e seus desenlaces na discussão subsequente, citamos Jou; Sperb (1999):

Astington e Olson (1995) salientam que, por um lado, os pesquisadores do desenvolvimento cognitivo consideram a criança como um "pequeno cientista" que, para explicar e predizer suas ações e a dos outros, infere os estados mentais causais subjacentes, como desejos e crenças. Por conseguinte, consideram a criança como construtora de uma teoria da mente, graças ao desenvolvimento de mecanismos cognitivos apropriados e o ambiente social provedor de instrumentos culturais. De outra parte, os pesquisadores do desenvolvimento social consideram que entender os estados mentais não tem a ver com a construção de uma teoria, mas sim, com a internalização da psicologia popular da cultura a qual a criança pertence. (JOU; SPERB, 1999, p. 303) 
No que concerne, especificamente, à interface com a linguagem e seu campo de estudos, a linguística, coloca-se a possibilidade de que ToM funcione em correlação com o desenvolvimento das categorias linguísticas. Uma vez que assim seja, todos os níveis de análise poderiam ser influenciados e influenciar o desenvolvimento em ToM.

No enfoque funcionalista da linguagem, entende-se que sintaxe e semântica estão abaixo da pragmática, considerada, por sua vez, o componente mais abrangente de análise. Desse modo, a gramática funcional trabalha com a hipótese de que a língua é composta por sistemas de regras estruturadas, que estão subordinadas, por sua vez, às atividades da convenção social (língua natural = estruturada + cooperativa), conforme já discutido anteriormente.

Sobre isso, a linguista Kerbrat-Orecchioni (1997, p. 268) afirma que a prática discursiva se faz no e pelo contexto de uso, necessitando ser, portanto, constantemente negociada, de modo a acomodar a dialética da identidade e a da diferença, para formar um conteúdo comum e partilhado. Em suas palavras:

\begin{abstract}
Porém, de todo modo, a troca verbal pode ocorrer somente na dialética da identidade e na da diferença: constitui-se sempre, e até mesmo no discurso controverso se aplica a regra, a partir daquilo que Labov denomina "conhecimento compartilhado" (shared knowledge) e Perelman chama de "base" (conjunto de feitos, verdades, suposições, valores que o falante supõe que seu público conhece), ao mesmo tempo que modifica, de certa forma, os conhecimentos e posições discursivas dos indivíduos presentes. (KERBRAT-ORECCHIONI, 1997, p. 268, tradução nossa) ${ }^{61}$
\end{abstract}

Conforme discutido no capítulo 2, no pólo funcionalista da linguagem, pensar em uso linguístico implica, necessariamente, considerar que existe uma influência direta da cognição e, de modo mais amplo, da teoria da mente.

Souza (2006), então, ao revisitar os temas já propostos na interface Psicologia e linguagem, ressalta a importância de se desenvolver estudos transculturais, capazes de abordar os achados empíricos concernentes ao direcionamento proveniente dos três níveis sinalizados acima: semântico (lexical ou

\footnotetext{
61 Original: "Pero de todas maneras, el intercambio verbal no puede efectuarse más que en la dialéctica de la identidad y de la diferencia: se constituye siempre, e incluso el discurso polémico no escapa a la regla, a partir de lo que Labov denomina un "conocimiento compartido" ("shared knowledge"), y Perelman una "base" (conjunto de hechos, verdades, presunciones, valores que el hablante supone que conoce su audiencia), al mismo tiempo que modifica de cierta manera los conocimientos y posiciones discursivas de los individuos presentes.”
} 
estrutural), sintático (sobretudo, referente à sintaxe de complementação) e, como nível norteador dos demais, pragmático.

No que se refere ao nível semântico, a autora aponta as pesquisas desenvolvidas por Lee; Olson; Torrance (1999). Os autores observaram que, no Chinês, distingue-se, lexicalmente, "pensar algo verdadeiro" de "pensar algo falso". Diante dessa peculiaridade semântica lexical, observou-se que as crianças apresentavam um domínio maior nas tarefas de crença falsa, quando tais usos eram feitos.

Porém, quando as crianças eram testadas com um item lexical neutro, para "pensar", comprovou-se que não houve mudança significativa em relação às crianças inglesas, para as quais só há opção neutra (think). Ou seja, entende-se que o item lexical atuou apenas para promover um resultado local, não um ganho geral em teoria da mente.

Com relação à sintaxe, de Villiers; de Villiers (2000) realizou testes cruzando sintaxe de complementação e tarefas de crença falsa, em estudo longitudinal com crianças surdas entre três e quatro anos. Chegou-se, então, à conclusão de que a aquisição de teoria da mente toma como pré-requisito a aquisição de sintaxe de complementação (SOUZA, 1996, p. 389), pois quanto mais as crianças se mostraram capazes de receber e produzir sentenças encaixadas tanto mais hábeis foram nas tarefas de crença falsa.

Por fim, no que diz respeito à pragmática, Souza (1996, p. 389) cita a pesquisa desenvolvida por Dunn; Brown; Beardsall (1991), com autistas. Os autores ressaltam, então, que um número reduzido de input (conversas familiares sobre desejos, intenções e emoções), nos anos iniciais, podem acarretar déficit no reconhecimento de emoções, por volta dos seis anos.

Assim, concluímos essa breve discussão, pela qual buscamos pontuar as possibilidades de haver relação entre linguagem e ToM.

Ao longo desse caminho, ressaltamos a importância de conhecer os estudos em ToM, remontando à gênese dos mesmos, tais como as pesquisas em neuropsicologia e neurociências, até chegar ao localizacionismo (área de Broca e área de Wernicke).

Alinhamo-nos, então, à abordagem funcionalista da linguagem, para compreender as propostas disponíveis sobre a relação entre cognição, cultura e 
desenvolvimento dos níveis de análise linguística (semântica, sintaxe e pragmática). Por fim, discutimos algumas das pesquisas já desenvolvidas sobre tais relações, apontando a influência da semântica lexical, da sintaxe de complementação e, por fim, da pragmática, citando a importância da interação referente a estados mentais, nos primeiros anos de vida.

A seguir, passamos às considerações acerca dos desafios propostos aqui e aplicados à aquisição de língua, em um contexto de bilinguismo (ou multilinguismo).

\subsection{Algumas considerações sobre PB (L2) e os usos mórficos}

Aprender a usar uma língua é uma tarefa bastante desafiadora, que se evidencia, sobretudo, no contato com uma segunda ou terceira língua.

Surpreende, então, que nenhuma criança se recorde, por exemplo, de ter precisado elaborar complexos modelos teóricos para entender o uso das classes de palavras de uma língua ou seu ordenamento (AKHTAR, 2001), tampouco categorizar regras de complementização (BLOOM; RISPOLI; GARTNER; HAFITZ, 2001). Contudo, toda criança com desenvolvimento normal desenvolve linguagem em tempo relativamente curto e de forma eficiente. E, mais, se submetida a ambiente com bilinguismo, não encontrará empecilho cognitivo para aprender tanto semântica e sintaxe quanto as regras pragmáticas vigentes ${ }^{62}$.

Langacker (1977, p. 21) postula que existiria um bilinguismo perfeito, mas que ele só seria possível até determinada fase do desenvolvimento e, arbitrariamente, propõe que "o começo da adolescência parece ser uma espécie de linha divisória da habilidade para se dominar um novo sistema." Por certo que isso não significa que o NLU se torne incapaz de aprender a se comunicar, por meio de linguagem verbal. Sua ressalva é de que esse aprendizado não teria similar qualidade, rapidez ou eficácia pragmática.

Nessa linha, Couto (2009) discute que é possível pensar o bilinguismo tanto como fenômeno societário quanto como desenvolvimento individual. Este teria como locus do contato a mente do indivíduo, e poderia ser elaborado, teoricamente, de três formas:

\footnotetext{
${ }^{62}$ Há linhas teóricas que consideram que não existiria bilinguismo perfeito, de modo que uma língua sempre se sobreporia à outra, sobretudo em níveis pragmáticos, conforme veremos em Myers-Scotton (2002).
} 
- Bilinguismo coordenado - o indivíduo aprende as duas línguas em ambientes distintos, mantendo separados os significados de cada item lexical;

- Bilinguismo composto - o indivíduo aprende as duas línguas no mesmo contexto e as usa ao mesmo tempo, ou seja, há uma fusão das duas no cérebro;

- Bilinguismo subcoordenado - o indivíduo aprende a interpretar os significados da língua secundária a partir da primária.

$\mathrm{Na}$ esteira do bilinguismo subcoordenador, é que se encontra a proposta de Myers-Scotton (2002), para quem estudar aquisição de L2 seria um mecanismo aceitável para entrever as estruturas dispostas na L1 (ou língua materna). Sobre isso, a autora define:

Para repetir aquilo que já escrevi em outra parte, os fenômenos do contato oferecem uma janela empírica sobre como a língua 'funciona'. Trata-se de uma janela especialmente transparente porque os dados de contato estão disponíveis para análise e porque quando duas ou mais variedades estão em contato, as suas estruturas estão frequentemente expostas, de uma forma não óbvia, se a língua é examinada por meio de dados monolíngues sozinhos. ${ }^{63}$ (MYERS-SCOTTON, p. xi)

Sobre aquisição de L1, Pinker (2004, p. 191) e Terwilliger (1974, p. 61) esclarecem que as crianças muito pequenas tendem a aprender nome e verbo como uma experiência única, uma vez que não distinguem aquilo que Fillmore (1976, 1977) denominara como frame, para o nível nominal, e scene, para o verbal. $\mathrm{Na}$ experiência dessa criança, portanto, nem mesmo palavra e objeto poderiam ser satisfatoriamente separados, pois o que a faz recorrer ao comportamento verbal seria o impulso de ter suas necessidades satisfeitas, independentemente de elas serem do campo das coisas (água, leite...), ou repercutir estado ou dinamicidade (dar carinho, abraçar...).

Akhtar (2001, p. 197), retomando a proposta de Fillmore (1976, 1977), afirma que as crianças, a partir de certa idade, passam a distinguir nome e verbo enquanto funções. Desse modo, ao mesmo tempo em que elas começam a entender função nominal e função verbal, dão-se conta do ordenamento, que subjaz à fala.

\footnotetext{
${ }^{63}$ Texto original: "To repeat what I've written elsewhere, contact phenomena offer an empirical window on how language 'works'. This is an especially transparent window because contact data are readily available for analysis and because when two or more varieties are in contact, their structures are often exposed in a way not obvious when a language is examined through monolingual data alone."
} 
As crianças adquirem o ordenamento de palavras de sentenças simples a complexas. Dentre as complexas, Bloom et al. (2001) postula que a aquisição de scomplements antecede wh-complements, o que permite com que as crianças ressignifiquem os usos de perguntas wh-, apenas em torno de sete anos.

No que se refere às sentenças simples, a ordem marcada é aprendida e distinguida pela pragmática, ou seja, pela linguagem em uso, com a qual a criança tem contato seja por via do cuidador, por interação com outras crianças ou por exposição não interacional.

Como a aquisição da criança parece ser pautada pela pragmática, conforme a proposição do modelo funcionalista da linguagem (CROFT, 1991; DeLANCEY, 2001), isso explicaria por que as crianças não tendem a aprender os verbos por escala de dificuldade, como quantidade de argumentos. Tomando o exemplo do Pykobjê-Gavião, uma criança não aprenderia, primeiro, sentenças intransitivas simples, depois, intransitivas estendidas e, somente após determinado período, transitivas. Antes, elas se apropriam dos usos verbais e lidam com eles dentro daquilo que sua escala de desenvolvimento linguístico e cognitivo permite. Ou seja, elas são limitadas não pela função, mas sim pela forma.

Conforme já se descobriu por experiências anteriores, o contato que fornece input tende a ser essencial para que uma criança se diferencie de uma máquina, por exemplo. Tomando os casos das "crianças selvagens", Victor e Genie ${ }^{64}$, percebemos que tanto Victor quanto Genie encontraram dificuldade poterior em expressar a linguagem humana, com todas as capacidades normalmente esperadas. Faltava-Ihes, dentre outras atribuições, o aprendizado da recursividade sintática, que é um dos principais marcadores de especificidade da linguagem humana, usada em todas as comunidades de fala.

Isso denota a importância do aprendizado e do estímulo sistemático, disponibilizados em idade adequada. A necessidade de se oferecer estímulo em dada fase da vida, para haver aproveitamento de potencialidades, recebeu o nome de "ponto crítico", por parte de algumas teorias do desenvolvimento, e postula o mesmo que Langacker (1977). O "ponto crítico" comprovaria, então, a intersecção

\footnotetext{
${ }^{64}$ Para conhecer um pouco mais sobre os estudos relativos à Genie, sugerimos uma visita ao website de Susan Curtiss: http://www.linguistics.ucla.edu/people/curtiss/. Acesso em: 13/06/2016.
} 
essencial entre biológico e social, entendendo social como interação entre pares e com um meio.

Pinker (2004, p. 277) realça que os animais não apresentam recursividade (nominal ou verbal), o que atuaria como um forte entrave para o ensino de línguas para animais ${ }^{65}$. Por outro lado, explica que máquinas são plenamente capazes de aplicar esse recurso, inclusive, com superioridade à observada em humanos, dada sua memória expandida. Mesmo assim, computadores não conseguem reproduzir a linguagem humana, uma vez que falham ao interpretar semântica e contextos de uso (pragmática), além de terem dificuldade para tomar decisões, diante de perguntas abertas (que não sejam do tipo sim/não) ${ }^{66}$. Ou seja, faltam às máquinas experiências de uso e depreensão de contextos. Sobre isso, Pinker (2004, p. 291), acrescenta: "Metáfora e humor são maneiras úteis de resumir as duas performances mentais que participam da compreensão de uma frase."

Em suma, o que a experiência fornece é que uma criança de sete anos terá melhor domínio de sua língua materna do que um estrangeiro com contato superior a esse período e se dedicando a estudos formais sobre a língua.

Tendo fornecido as pistas gerais de desenvolvimento e aquisição, podemos pensar de modo um tanto mais específico, como se daria o aprendizado de determinados níveis em contexto de L2, de modo a aplicar tal perspectiva à linguagem escrita, produzida por indígenas Gavião, em curso específico e já mencionado. Tomemos, então, o raciocínio do modelo teórico proposto por MyersScotton (2002), conhecido pela sigla MLF (Matrix Language Frame $)^{67}$.

O modelo de língua matriz, MLF, pressupõe que não exista nunca bilinguismo perfeito. Isto significa que as línguas sempre estão em assimetria dentro da mente do falante, que é o locus primordial do contato. Então, caberia ao linguista descrever qual é a língua matriz (Matrix Language - ML) e qual é a língua encaixada (Embedded Language - EL), em dada situação de contato.

No caso dos falantes bilíngues de Pykobjê-Gavião e PB, por exemplo, não fica difícil saber, a partir dos dados históricos do contato, que o Pykobjê-Gavião foi

\footnotetext{
${ }^{65}$ Atualmente, os pesquisadores estão optando por ensinar animais em Língua Americana de Sinais, o que tem gerado efeitos surpreendentes. Contudo, ainda não se teve notícias de animais que tenham conseguido aprender algo próximo da recursividade.

${ }^{66}$ Quanto às decisões, isso ocorre porque nenhum programa digital foi capaz de recriar uma Teoria da Mente.

${ }^{67}$ Por fins didáticos, optamos por manter, nesse trabalho, as siglas que a autora vem utilizando em suas análises e explanações sobre o assunto abordado.
} 
escolhido pelos falantes como a língua matriz (ML), enquanto que o PB atua como a língua encaixada (EL). Mas como chegaríamos a essa conclusão, se, ao contrário do que ocorre, desconhecêssemos os fatores externos que envolvem essa comunidade de fala?

Pois bem, a predição do modelo de Myers-Scotton (2002) sobre esse assunto leva à elaboração de outro modelo, conhecido por Princípio da Estrutura Uniforme (Uniform Structure Principle, doravante USP). O USP propõe que o bilíngue sempre prefere as estruturas abstratas advindas da língua matriz.

Apesar de a autora estar pensando, sobretudo, em casos de Codeswitching (CS), quando elabora esse Princípio, parece bastante coerente espraiá-lo à nossa discussão. Fazendo-o, encontramos base linguística para assegurar que, de fato, o Pykobjê-Gavião é que é a ML, e não o PB. Afinal, é do Pykobjê-Gavião e não do PB, que vem a estrutura abstrata da língua de contato usada pelos Gavião. E essa afirmação se sustenta, quando olhamos para o quadro mórfico do PB, produzido pelos Pykobjê-Gavião, na língua escrita. A língua escrita, por sua vez, traz a vantagem de permitir o tempo da escrita para reflexão sobre quais usos seriam mais pertinentes, o que nos leva a crer que, em linguagem falada, encontraríamos um campo ainda mais fértil para desenvolver tal discussão.

Portanto, na produção desse conjunto de redações, foram exigidas duas capacidades dos Gavião: a tarefa de escrever e a de escrever em uma língua estrangeira.

Voltando ao modelo de Myers-Scotton (2002), os Gavião, nessas redações, enfrentaram desafios que foram além do fato de terem de se comunicarem em EL. Por outro lado, tiveram a vantagem de poder refletir um pouco mais sobre os usos que fariam dos morfemas da EL. Além disso, não podemos nos esquecer de que os produtores das redações são falantes um tanto mais fluentes de PB, pois estão mais associados à educação formal nesta língua.

Seguindo Myers-Scotton (2002), resolvemos, portanto, fixar o quadro mórfico. A autora desenvolve, sobre esse assunto, um modelo teórico de aplicabilidade universal, a que chama de modelo dos 4 morfemas (4-M model), e sua proposta é que há morfemas mais facilmente "transferíveis" do que outros, no processo de aquisição. Portanto, haveria um acesso diferencial aos morfemas da EL. 
Essa hipótese ficou conhecida como a Hipótese do Acesso Diferencial (Differential Acess Hypothesis). Sobre ela, Myers-Scotton (2002) afirma:

Os diferentes tipos de morfemas do modelo dos 4-M são diferentemente acessados nos níveis abstratos do processo de produção. Especificamente, morfemas de conteúdo e morfemas gramaticais precoces são acessados no nível do léxico mental, mas os morfemas gramaticais tardios não se tornam salientes até o nível do formulador. ${ }^{68}$ (MYERS-SCOTTON, 2002, p. 69)

Retomando Thomason \& Kaufman (1988), podemos afirmar que ocorre um "aprendizado imperfeito" da língua em aquisição. Contudo, apostamos que essa "imperfeição" pode ser prevista pela Hipótese do Acesso Diferencial, que complementa o Modelo dos 4 morfemas (4-M model), de Myers-Scotton.

O 4-M model distingue quatro tipos mórficos. E o faz por meio de três pares de oposição: [ \pm conceptualmente ativado] (conceptually activated), [ \pm atribuidor/receptor de papel temático] (thematic role receiver/assigner) e [ \pm exterior à projeção máxima do núcleo imediato] (looks outside its immediate maximal projection for information about its form).

A primeira oposição que expusemos, ajuda a diferenciar os morfemas em: morfemas de conteúdo e morfemas gramaticais. Essa oposição mórfica, apesar de já ser uma questão antiga da linguística geral, recebeu novos contornos, ao levar em consideração as intenções comunicativas do falante.

Desse modo, um morfema [+ conceptualmente ativado] é aquele que é ativado no nível do lema ${ }^{69}$, portanto, é dotado de conteúdo semântico. São os morfemas de conteúdo (content morphemes) e os morfemas gramaticais de aquisição precoce (early system morphemes). Por sua vez, os morfemas de conteúdo se diferenciam dos morfemas precoces pelo fato de os primeiros serem [+ atribuidor/receptor de papel temático].

Os morfemas de conteúdo são aqueles dos quais os falantes mais querem se apropriar na EL, pois desse domínio depende a eficácia comunicativa. Se alguém

\footnotetext{
${ }^{68}$ Texto original: "The different types of morphemes under the 4-M model are differentially accessed in the abstract levels of the production process. Specifically, content morphemes and early system morphemes are accessed at the level of the mental lexicon, but late system morphemes do not become salient until the level of the formulator."

${ }^{69}$ O lema, segundo Levelt (1989), é um nível abstrato intermediário que fica entre o nível conceptual e o nível funcional (apud PETTER, 2008, p. 60). Para Myers-Scotton (2002), o lema deve ser entendido como um construto de operações com informações de ordem sintática, semântica, pragmática e morfofonológica.
} 
diz: "Quero um copo de aguardente" por "Quero um copo de água", certamente, terá sérios problemas sociais. Mas alguém que diga: "Quero uma copo do água”, ainda assim será atendido em sua necessidade. Devido a isso, afirma-se que os morfemas de conteúdo são mais facilmente transferíveis do que os demais.

Abaixo, dispomos uma imagem, a fim de permitir uma visualização mais ampla do esquema proposto por Myers-Scotton (2002, p. 73):

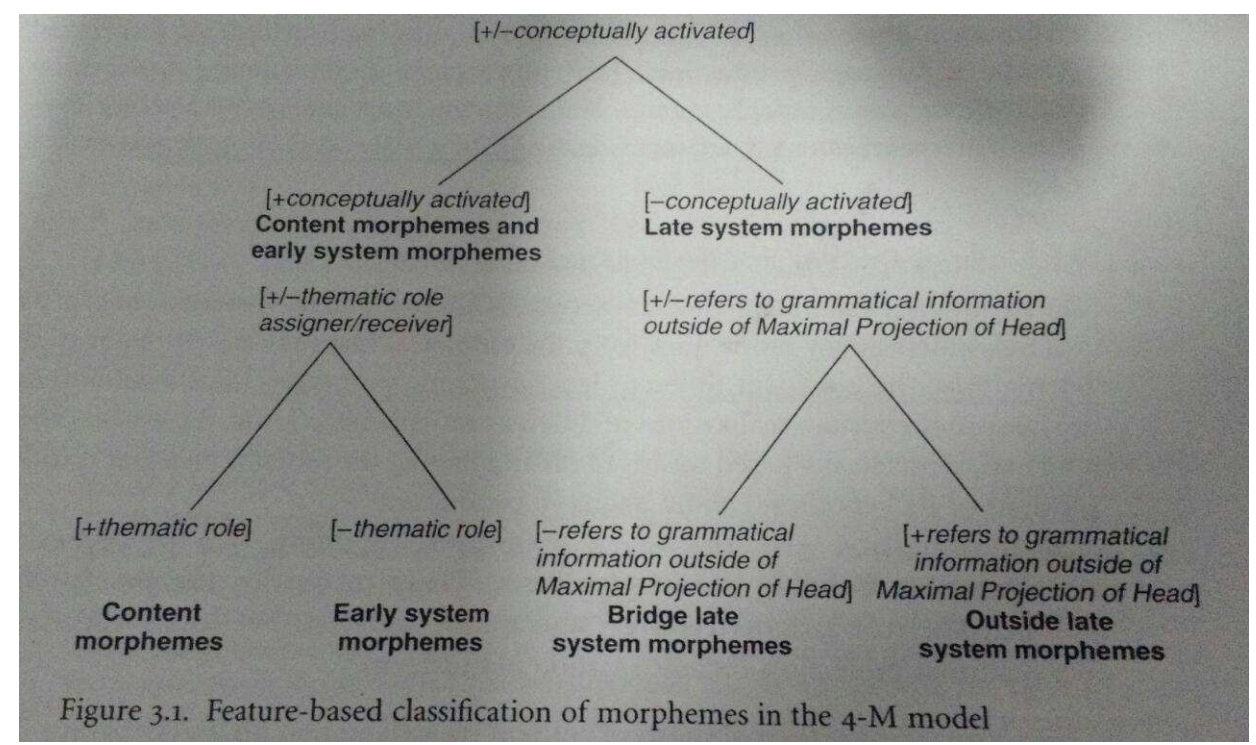

Classificação de traços dos morfemas, segundo o modelo dos 4-M (MYERS-SCOTTON, 2002, p. 73)

Então, nesse aspecto, não há muita diferença a ser reportada, entre as redações dos Gavião e as escritas por um falante nativo de $\mathrm{PB}$, a não ser pelo fato de os indígenas utilizarem, deliberadamente, morfemas de conteúdo advindos de sua ML, a fim de atuar como um elemento de identidade. Desse modo, todos os exemplos encontrados nas redações pertencem à classe dos substantivos e refletem o universo cultural em que os Gavião estão inseridos, enquanto comunidade de fala.

A opção pelo empréstimo dos substantivos da ML, e não pelos verbos, não é algo trivial. Para Myers-Scotton (2002), isso seria decorrente da não apropriação sintática, enquanto que, para funcionalistas, seria uma evidência tanto em aspecto formal quanto e, eis o mais relevante, no que se refere ao conhecimento sobre função e papel semântico. Conforme explicita Myers-Scotton (2002):

A explicação depende de uma leitura mais ampla para ativação conceitual. Enquanto os verbos também são [+ conceptualmente ativados], eles são mais difíceis de serem emprestados (ou de serem inseridos em uma Língua Encaixada em codeswiting) de uma língua a outra porque, diferente dos 
nomes, os verbos são [+ atribuidor de papel temático] e, portanto, carregam maior bagagem sintática do que os nomes, o que significa que sua relação com a língua recipiente pode ser mais difícil de se fazer. ${ }^{70}$ (MYERSSCOTTON, 2002, p. 53)

Desse modo, observamos a apropriação de nomes de frutas, de jogos, de lugares e, sobretudo, das palavras kopẽ e mehẽ, que significam, respectivamente, "homem não índio" e "meu povo".

Uma observação interessante a se remarcar é que esses termos tomados da ML, muito raramente, aparecem flexionados em gênero ou em número. Em geral, escolhe-se o gênero masculino, que é o não marcado no PB, para ser o gênero do determinante ou definidor dos morfemas de conteúdo do Pykobjê-Gavião.

Já com relação ao número, o determinante pode ser flexionado no plural ((e)s). Porém, os morfemas de conteúdo tomados do Pykobjê-Gavião só aparecerão flexionados no número singular, que, assim como o gênero masculino, é o não marcado em língua portuguesa. E, para exemplificar o mecanismo da retomada dos morfemas de conteúdo da ML na EL, vejamos um trecho da redação do índio Severino Gavião:

"No meu município o contato com o kupẽ é um pouco dificie por que tem outros kupẽ que não gostos dos mehẽ, mais tem outro kupẽ que gosta dois índios..."(grifos nossos)

No que diz respeito aos morfemas gramaticais de aquisição precoce (early system morpheme), há muito a ser dito por meio das redações dos Pykobjê-Gavião, pois sabemos que um falante nativo de $\mathrm{PB}$, dificilmente confundiria o gênero do determinante de dado substantivo, a menos, é claro, que se tratasse ou de uma palavra desconhecida pelo falante, ou fosse uma situação de empréstimo recente, como é o caso de xerox, que ainda não fixou artigo na fala popular, embora haja indícios de que convenha usar 'o' xerox, para indicar o local de proveniência do mesmo, e 'a' xerox, para remeter à cópia em si.

Isso ocorre porque o determinante ou definidor (ex.: pronomes possessivos) é um tipo de morfema de aquisição precoce, já que, quando uma criança adquire uma

\footnotetext{
${ }^{70}$ Texto original: "The explanation hinges on a plus reading for conceptual activation. While verbs also are [+ conceptually activated], they are more difficult to borrow (or to insert from the Embedded Language in codeswiting) from one language to another because - unlike nouns - they are [+ thematic role assigner] and therefore carry more 'syntatic baggage' than nouns, meaning their fit with the recipient language may be harder to make."
} 
palavra em ML, o artigo viria "ligado" a ela. Mas, o mesmo não acontece na aquisição de segunda(s) língua(s), ou melhor, de EL, por isso aprender uma língua como o Francês, que apresenta três artigos definidos (les (plural para ambos os gêneros), la (feminino singular) e le (masculino singular)), torna-se uma tarefa tão demorada e árdua para qualquer adulto.

Myers-Scotton (2002), em seu modelo, afirma que os morfemas gramaticais precoces são aqueles que marcam os traços phi de pessoa, número e gênero, que sejam relevantes na língua em análise. No caso da língua portuguesa, por exemplo, dois dos três traços podem ser distinguíveis para a classe dos artigos: gênero e número (artigos definidos do português: a, o, as, os).

Sobre a variante linguística em foco, sabemos que o Pykobjê-Gavião não apresenta artigos, ou seja, seu gênero não é redundante, como ocorre na língua portuguesa, que marca o gênero ${ }^{71}$ na palavra e em seus adjuntos, além de explicitálo no artigo ou definidor preposto ao sintagma nominal, que, em geral, deve ser foneticamente expresso. Isso se dá porque, em PB, quando o determinante não aparece marcado em gênero (ou seja, Det $=\varnothing$ ), é sinal de que alguma questão semântica está sendo realçada em Noun Phrase (NP). Esse recurso recebe a designação de "nome nu".

Em geral, podemos dizer que nomes massivos, isto é, que não podem ser contados, como "ferro" e "água", não serão antecedidos por um artigo, em PB, a menos que a intenção seja de especificação semântica, conforme observamos nos exemplos abaixo:

9. O João comprou ferro para confeccionar uma peixeira nova.

O ilusionista amassou o ferro (o ferro do talher) com o poder da mente.

10. João, estou sedento. Quero água!

$\mathrm{O}$ detergente contaminou a água (a água do riacho $\mathrm{X}$ ).

Então, uma das provas linguísticas de que o Pykobjê-Gavião é que funciona como a ML para os Gavião bilíngues, está no fato de eles se confundirem no

\footnotetext{
${ }^{71}$ Não podemos deixar de lembrar que a noção de gênero não se confunde com a noção de sexo. Para entender melhor essa percepção, recomendamos a leitura de ROCHA, L. C. A. Estruturas morfológicas do português. Belo Horizonte: Editora UFMG, 1998.
} 
momento de marcarem o artigo das redações selecionadas. E, para exemplificar, colocamos mais um trecho da redação do índio Severino Gavião, a mesma vista logo acima:

"(...) os indio faz a mizade com branco quando ele conhece, e o branco também a ceita $\underline{0}$ amizade dele, e há ir que o índio começa fazer, negocio (...)" (grifos nossos)

Podemos observar que o informante apresenta dificuldade para verificar, inclusive, os limites das palavras. Por isso, no substantivo 'amizade' e no verbo 'aceitar', ele marca, na escrita, o som de /a/ inicial, talvez, para remeter ao artigo definido feminino do PB. Em seguida, retoma a palavra 'amizade' incorporando o 'a' inicial e a marca com o gênero masculino, que é evidenciado por meio do artigo definido masculino, "o". Isso demonstra que esse vocábulo não está internalizado na mente do falante, portanto, ainda está disposto a uma regularização gramatical, em que o gênero não marcado é, em geral, o preferido ('o amizade').

$E$, por fim, nesse trecho, percebemos que o informante remete a uma heterogenia da fala no que concerne ao reconhecimento da conjunção, que atua como um marcador conversacional, o vocábulo 'aí'. Porém, na escrita, apareceu como "há ir", o que seria bastante estranho, dada a ausência do conectivo "que", que ligaria o existencial "haver" ao verbo de movimento "ir", o que caracteriza um equívoco de notação.

Parece que esses casos, em que a preposição e/ou a conjunção são suprimidas, denotam a fala de PB própria dos falantes não nativos dessa língua, como é o caso dos Gavião. E esse tipo de situação é prevista e descrita no modelo de Myers-Scotton (2002) como algo concernente ao que a autora denomina "morfemas gramaticais tardios ponte" (bridge late sytem morphemes), a serem melhor discutidos adiante.

Retomando a discussão acerca dos morfemas gramaticais precoces do PB, podemos afirmar que o gênero do PB soa tão redundante, que poderia ser espraiado a todo o sintagma nominal. Vejamos, então, como isso se manifesta na escrita:

"Antigamente o meu povo canta no patio a noite inteiro para que eles não esquecer da cultura tradicional..." (grifos nossos) 
Como esse tipo de inadequação não seria, a priori, verificado em textos de um falante nativo de PB, senão por descuido - o que não é o caso, por ser recorrente -, fica claro que se trata de uma influência da ML, o Pykobjê-Gavião, em que não há concordância orientada por flexão.

Em outra redação, agora do índio Urbano Gavião, percebemos semelhante inadequação de concordância, dessa vez com o pronome indefinido, 'muito', que é homônimo no PB do advérbio de intensidade 'muito'. No entanto, o pronome de função adjetiva, 'muito', difere do advérbio, porque o primeiro é variável, ou seja, deve concordar em gênero e número com o substantivo, a que está sintaticamente relacionado.

Nas redações, esse pronome com função de adjetivo nem sempre aparece com marca de gênero e/ou número, o que denota incerteza por parte do falante perante o uso do pronome "muito". Isso não ocorreria se a ML do informante fosse o PB, ainda que na norma não padrão, pois o PB não culto, de todo modo, marcaria o gênero, que é um morfema precoce. E a mesma regra de concordância, que há para o pronome "muito", também se aplica ao substantivo na função adjetiva, 'próximo'. Vejamos, então, os trechos pertinentes da redação selecionada:

\footnotetext{
"Aldeia fica proximos a cidade Amarante.

Temos muito nascente, perto da aldeia.

Moramos na chapada, muitas árvores, pé de pegue, mangaba, caju.

Proximo da aldeia mora muitas guajajara ${ }^{72}$ e os fazendeiro.

(...)

Temos fruto variada, bacaba, juçara, buriti.

A minha aldeia, é grande tem muitas gente." (grifos nossos)
}

Na primeira linha do exemplo, vemos um uso de "próximo" que um falante nativo de $\mathrm{PB}$ relutaria em realizar. $E$, provavelmente, diria a mesma frase do seguinte modo: "A aldeia fica próxima da cidade de Amarante" ou, mesmo, "A aldeia fica próximo da cidade de Amarante".

Ou seja, colocaria um artigo definido antes do NP "aldeia", para restringir o assunto à aldeia em questão, conforme já discutimos acima. Aplicaria a concordância de gênero feminino, que é o marcado do português, ao substantivo

\footnotetext{
${ }^{72}$ Guajajara é o nome de um povo indígena que ocupa um pequeno espaço de terra, cedido pelos Pykobjê, na área que lhes foi delimitada pelo convênio Funai/Radam, em 1977.
} 
"próximo", que está relacionado ao nome "aldeia", ou, a depender de seu domínio escrito, poderia colocar o masculino, de modo a generalizar, mas, provavelmente, não usaria masculino e plural. E, por fim, utilizaria um morfema gramatical tardio de tipo ponte (bridge late system morpheme), que está previsto no modelo de MyersScotton: 'próxima de Amarante' ou 'próxima à Amarante'.

Já o segundo uso de "próximo", que aparece na linha 4 do exemplo proposto acima ("Proximo da aldeia mora muitas guajajara e os fazendeiro"), poderia muito bem ser utilizado por um falante nativo de PB, se entendermos que "próximo da aldeia" funciona como um locativo completivo do verbo 'morar', que, por sua vez, pode tomar dois complementos: quem mora e onde mora. Então, nesse exemplo, o "próximo" funciona de modo muito similar ao advérbio 'perto', que, como os demais advérbios, também, não concorda em gênero ou número com seu complemento.

Com relação aos usos do pronome indefinido com função de modificador (adjetivo), 'muito', as coisas ocorrem, exatamente, como indicado na discussão anterior ao exemplo, isto é, não há um uso regular de concordância. Na última linha do trecho retirado ('A minha aldeia, é grande tem muitas gente') vemos que o informante realiza uma concordância semântica com o vocábulo de morfologia singular, 'gente'. E essa "confusão" pode ser mais do que uma concordância semântica/ideológica. Pode indicar influências do contato com a ML do falante, em que 'a gente' apresenta uma evidente morfologia de nome plural, conforme indicado no exemplo abaixo:

$\begin{array}{lcc}\text { 11. } \begin{array}{l}\text { cate } \\ \text { muito }\end{array} & \mathrm{jOL} \text { - acry } & \text { PR-estar.alegre/alegre }\end{array}$

'A multidão está alegre'

Desse modo, se utilizar a concordância de gênero já se mostra difícil, quando o vocábulo com função de adjetivo está posicionado na frase ao lado do nome, nos casos em que há a interpolação de um verbo cópula ou oração relativa, as chances de 'acerto de concordância de gênero caem drasticamente nas redações.

E, para exemplificar essa asserção, escolhemos uma das redações mais bem elaboradas em relação ao uso e à fluência na escrita em língua portuguesa. O tema proposto pela professora Rosane era: "Conte como eram as tradições de seu povo 
no passado, como elas estão sendo preservadas atualmente e como você pensa que elas estarão no futuro".

Nós a transcreveremos abaixo, ipsis littera e na íntegra, para que tenhamos a verdadeira percepção de que, apesar da escrita exemplar, o informante Wesley ${ }^{73}$ apresenta inadequações que um falante nativo de PB, com tal fluência na escrita, raramente manifestaria:

"Eu vou contar uma história que meu avô contou para mim, como era vida deles no passado.

Bom a vida do meu povo era trânquilo, Eles caçavam, pescavam e levavam uma vida boa.

Antigamente, quando não tinha cupẽ, tinham muitas caças, peixes, frutas, terra fértil.

A cultura era muito mais forte as nossas linguas, os costumes, as cantigas, músicas, festas, comidas e outros.

Hoje, atualmente tudo está diferente para nós.

Com a chegada de homem branco, as caças acabaram, tem cacas mas poucos, as frutas estão poucas, peixe, madeiras para fazer casas.

E a cultura nossa está comprometida por causa de energia, gravador, rádio, roupa, dinheiro, comidas do cupẽ e muitos costumes de cupẽ que é praticada na aldeia como futebol e etc...

No futuro não sei o que vai ser de nós se vai ficar bom para nós ou não.

Espero que nós os jovens de todas as Etnias lutem pelos nossos direitos. Assim teremos uma vida boa trânquila para nossas crianças e netos." (grifos nossos)

Logo na segunda linha ("Bom a vida do meu povo era trânquilo, Eles caçavam, pescavam e levavam uma vida boa."), fica patente inadequação no uso da concordância de gênero, pois o informante realiza uma concordância de gênero atrativa, isto é, atraída pelo substantivo ('povo'), que está mais próximo do modificador ('tranquilo'). O recomendado para o PB, nesse caso, seria que se fizesse a concordância com o gênero do núcleo do sujeito sintático, que, no caso, seria 'vida'.

Em seguida, o informante retoma o adjunto adnominal, 'meu povo', pelo pronome masculino plural ('eles'), o que indica, novamente, uma retomada semântica/ideológica e não morfológica. Contudo, não podemos afirmar que um falante nativo de PB jamais faria isso em uma escrita informal e descuidada ou, mesmo, no discurso oral. Por isso, esse dado não serviria como base linguística

\footnotetext{
${ }^{73}$ Um trecho dessa mesma redação foi discutido no capítulo 3.
} 
para a afirmação de que o Pykobjê-Gavião seria língua filtro ou a ML desses bilíngues.

No entanto, no sexto parágrafo, encontramos algo mais interessante para ratificar nossa hipótese. Trata-se de uma inadequação, novamente, no uso concordância do gênero do modificador 'pouco', que vem depois do síndeto de oposição, 'mas' (“Com a chegada de homem branco, as caças acabaram, tem caças

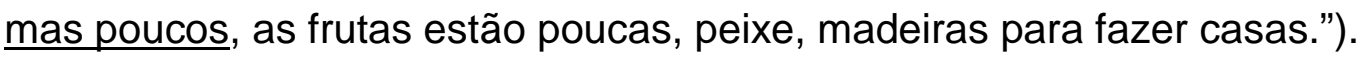

$\mathrm{E}$, no parágrafo seguinte, as inadequações se acirram, quando o informante se arrisca a empregar uma série de sentenças encaixadas ("E a cultura nossa está comprometida por causa de energia, gravador, rádio, roupa, dinheiro, comidas do cupẽ e muitos costumes de cupẽ que é praticada na aldeia como futebol e etc...")

O mais comum para um falante nativo de PB não culto seria retomar apenas o gênero do último elemento, que antecede uma oração relativa com antecedente apositiva, como acima. Então, para haver gramaticalidade, teríamos algo assim: "(...) por causa de energia, gravador, rádio, roupa, dinheiro, comidas do cupẽ e muitos costumes de cupẽ que é praticado na aldeia como futebol e etc..."

Desse modo, por menor ensino formal que tivesse, um falante nativo de PB relutaria em produzir uma sentença, cuja concordância de gênero não estivesse minimamente satisfeita.

O mesmo já não ocorre com a concordância de número, que na variedade não culta de PB, costuma ser marcado apenas em um modificador do sintagma. Desse modo, uma sentença como (12) poderia vir de um falante nativo de PB, mas (13), raramente:

12. As menina comprou dois sanduíche de queijo.

13. As menino comprou duas sanduíche de queijo.

Por isso, não levamos em consideração a concordância de número em DP, para afirmarmos uma diferença entre o PB e o Pykobjê-Gavião. Além dos gêneros dos modificadores, em $\mathrm{PB}^{74}$, também se enquadrariam como morfemas gramaticais

\footnotetext{
${ }^{74}$ Myers-Scotton (2002) faz questão de deixar claro que o 4- $M$ model deve ser entendido e interpretado em cada língua: "I emphasize that cross-linguistically the classification of morphemes in terms of the 4-M model can differ; that is, the same lexical categories or types of affixes are not necessarily the same types of 4-M model morphemes".
} 
precoces, as desinências números-pessoais dos verbos, pois elas devem ser ativadas no mesmo momento em que o indivíduo produz a estrutura verbal.

No caso do Pykobjê-Gavião, conforme discutido anteriormente (SILVA, 2012), o tempo (tanto absoluto quanto relativos) é não marcado e indicado por meio de itens ou de expressões lexicais. Além disso, parece haver uma divisão entre passado e não passado, mais evidente, ao se analisar o nível aspectual, conforme discutiremos mais detidamente nos capítulos 6 e 7. Abaixo, dispomos um breve resumo:

ry'hy e cormy, para marcar aspecto perfectivo em tempos do não passado;

ry'my' ou cahör, em distribuição semântica complementar, para marcar aspecto imperfectivo habitual;

cormy, a depender do contexto, para indicar aspecto imperfectivo contínuo progressivo.

Além disso, o único modo distinguido é o referente ao modo irrealis, por meio da partícula $\{$ ha $\}$.

No que diz respeito ao sistema de marcação pessoal, as palavras fóricas (nomes próprios ou pronomes) podem aparecer separadas morfologicamente do verbo, no caso de NPr, PI ou PE, ou aglutinadas ao mesmo, como ocorre com uso de PD.

Já no caso dos verbos do Português (tipologia predominantemente flexional), distingue-se modo e tempo por um morfema cumulativo, que é a desinência modotemporal (DMT), e número e pessoa, por meio de uma desinência número-pessoal (DNP), igualmente cumulativa.

Desse modo, os verbos poderiam ser decompostos em Regra de Análise Estrutural (RAE), de acordo com Câmara Jr. (1997), em: raiz + desinência modotemporal $(\mathrm{DMT})$ + desinência número-pessoal (DNP). Em 'colocávamos'75, por exemplo, podemos visualizar todas as partes que compõem a estrutura verbal: coloc- (raiz) + -a- (vogal temática - VT) + -va- (DMT) + -mos (DNP).

Tradução: "Enfatizo que através das línguas a classificação de morfemas de acordo com o modelo dos 4-M pode diferir; isto é, as mesmas categorias lexicais ou tipos de afixos não correspondem necessariamente aos morfemas propostos pelo modelo dos 4-M."

${ }^{75}$ Segundo gramática prescritiva, seria o correspondente a: pretérito imperfeito do indicativo. 
No entanto, um falante nativo de PB, que adquiriu a norma não culta, tende a homogeneizar a concordância de DNP, de modo que esta apresente apenas a distinção entre $1^{\text {a }}$ pessoa do singular e demais pessoas do discurso. Então, podemos esperar que esse falante produza algo como $^{76}$ : eu coloquei, tu/você colocou, ele colocou, nós colocou, vós/vocês colocou, eles colocou. Mas ele relutaria em substituir primeira pessoa do singular por terceira pessoa do singular ou plural, como os Gavião podem fazer, conforme aparece no trecho selecionado abaixo da redação do índio Manoel Sansão Gavião:

"Quando eu ssaiu (...) mais eu tiver que falar com essa pessoa, dono do comercio fala para mim o que você quer vamos fazer compra a que na minha mau mas eu procurem pra você..." (grifos nossos)

Nesse exemplo, o informante comete equívoco ao utilizar o morfema gramatical precoce, "eu procurem" por "eu procuro", em que a DNP do verbo "procurar", que é regido pela 1a pessoa do singular do presente do indicativo (DMT: $\varnothing)$, corresponde a DNP da 3a pessoa do plural, cuja marca é /-m/.

Ainda dentro do quadro dos morfemas gramaticais precoces, podemos enquadrar os casos das preposições de verbos sintagmáticos (phrasal verbs), em que as preposições ajudam a constituir o sentido do verbo. Em PB, o verbo "falar" serve como um ótimo exemplo desse caso. Temos, portanto, as seguintes construções: "falar para o João comprar algo", "falar com a Maria", "falar de/sobre negócios". E, no exemplo citado acima, percebemos que esse NLU Gavião fez um uso adequado dessas preposições precoces. Então, temos "falar com" e "falar para", aplicados de acordo com o sentido desejado pelo falante.

Tudo isso comprova, que apesar dos acertos, todos os informantes Gavião apresentam alguma dificuldade no uso dos morfemas gramaticais precoces do PB, sua EL. Tendo visto isso, é tempo de retomar o modelo de Myers-Scotton, a fim de estudarmos os outros dois tipos mórficos já sinalizados.

Então, passemos à segunda etapa do 4-M model de Myers-Scotton, observando os morfemas que são [- conceptualmente ativado]. Sobre esse tema já deixamos saber que há dois tipos mórficos, que se diferenciam pela oposição [ \pm

\footnotetext{
${ }^{76}$ Segundo gramática prescritiva, seria o correspondente a: pretérito perfeito do indicativo.
} 
exterior à projeção máxima do núcleo], e que ambos são representados por morfemas gramaticais (sem conteúdo semântico) de aquisição tardia.

Os morfemas gramaticais tardios ponte (bridge late system morphemes) são, desse modo, [- conceptualmente ativados] e [- exterior à projeção máxima do núcleo], conforme já entrevistos em exemplos anteriores.

Os morfemas tardios ponte são aqueles que, como o nome evidencia, promovem uma ponte entre morfemas de conteúdo. E essa "ponte" não faz qualquer referência ao conteúdo dos núcleos relacionados, daí ser [- exterior à projeção máxima do núcleo].

Estruturalmente, podemos afirmar que o Pykobjê-Gavião é bastante diferente do Português. No dialeto Timbira há preferência por pospostos ao núcleo (posposições), enquanto que, em Português, os elementos são preferencialmente antepostos ao núcleo (preposições), o que responde a especificidades de padrão de ordenamento previsto para línguas naturais, conforme discutido em Silva (2012). Para o Pykobjê-Gavião, seguem alguns exemplos, com marcação do conteúdo verbal:

14. xoore me rop ngõr raposa e onça dormirlNTR

'A raposa e a onça dormiram'

15. cahỹj köt ha ãpraa ẽjryry ny mulher ser.alta/alta IRR acordarINTR cedoADV PT 'A mulher alta acordará cedo'

16. copry - te cö japrö menina-ERG água comprar 'A menina comprou água'

17. copry - te ẽncreere - mỹ cö jõor menina-ERG criança-BEN água dar 'A menina deu água para a criança'

Além dessa diferença referente ao ordenamento sintagmático, a relação paradigmática também diverge. Com relação ao $\mathrm{PB}$, podemos dizer que os 
elementos ponte mais recorrentes no uso são a preposição funcional 'de' (sentença básica) e a conjunção 'que' (orações relativas com antecedente). Já em PykobjêGavião, a relação tende a ser feita por meio de prefixos relacionais (sentenças básicas) e/ou uso de determinadas partículas complementizadoras, como nỳ:

18. wa ẽj-te jõm cahỹj cën nỳ h-arẽn

1PI 1PD-ERG PIND mulher feia PC PR-dizer

'Eu disse que a mulher era feia'

Tomando o trecho da redação do índio Urbano Gavião, percebemos que a ausência ou o mau emprego desses morfemas é responsável por conferir boa parte da sensação de estranhamento:

"O contato com cupê; Porque nós comprar mercadoria tem já todo contato com cupê. Porque temos contanto com branco sobre envasões.

Através da lei temos contato com eles para ajudar em qualquer coisa se estive então entramos contato." (grifos nossos)

Nesse trecho, em que o índio Urbano Gavião fala sobre a importância do contato com os não índios, percebemos que houve um mau emprego desses morfemas ponte. E isso é bastante característico da escrita/fala não só dos Gavião, mas de quaisquer falantes não nativos de PB.

Além dos morfemas gramaticais tardios ponte, temos previsto no modelo os morfemas gramaticais tardios exteriores (outsider late system morpheme), que são [conceptualmente ativados] e [+ exterior à projeção máxima do núcleo]. Seu nome também é transparente, no sentido de que esses morfemas, realmente, precisam de uma informação, que esteja externa ao núcleo, para completarem seu sentido.

Retomando a Hipótese do Acesso Diferencial (Differential Acess Hypothesis), vista acima, podemos afirmar que os morfemas gramaticais tardios exteriores são, em geral, os mais difíceis de serem adquiridos. Podemos considerar como morfemas gramaticais tardios exteriores do PB, dentre outras coisas, as DMT, que assinalam a concordância entre sujeito e verbo. E é nesse item, que percebemos as maiores discrepâncias nas redações dos Gavião. 
Logo abaixo, podemos observar essa "confusão" com relação ao tempo verbal:

“(...) Elis dizer que antigamente uma pessoa que chama camum, Este homem gostava muito dessa moça olha só pai dessa mulhe falo civocê vai ganha de mir você leva Ela para que niquen porssu levala paru outro lugar quando essa menina chega na sua roça Ela fala com Ete homem venha praca desse Eu pentia o seu cabelo..." (grifos nossos)

Então, apesar de haver um advérbio temporal explícito, que marca o tempo do discurso como sendo o passado ("antigamente"), o NLU mistura presente, passado e futuro, em um mesmo parágrafo, o que aponta ao desordenamento acerca das regras de tempo, aspecto e modo do PB.

O propósito inicial dessa redação era contar alguma lenda típica do povo Gavião. Mas as lendas, para os indígenas tradicionalistas, isto é, para aqueles que vivem e recriam as tradições, é sempre uma conversação entre o passado e o presente enunciativo. Além disso, as evidências apontam que, em Pykobjê-Gavião, o reconhecido presente narrado (COMRIE, 1976, p. 72) se manifesta, morfologicamente, como passado.

Analisando o trecho disposto, logo no início, há inadequação na marcação do presente do indicativo, que aparece na $3^{\underline{a}}$ pessoa do plural em sua forma do infinitivo inflexionado ("dizer"). Em seguida, o informante deixa de marcar a DMT do pretérito imperfeito do indicativo, cuja marca é $\{$-va\}, em um dos verbos ("chama").

Adiante, também observamos o uso inadequado do presente do subjuntivo ("possa"), tanto no que diz respeito à DMT quanto à DNP, discutida anteriormente. O NLU lança mão do pronome indefinido de pessoa, 'ninguém', e o faz concordar, morfologicamente, com a $1^{\underline{a}}$ pessoa do singular do presente do indicativo, eu "posso".

Por fim, mantém alguns verbos no presente do indicativo ('chega', 'fala'), quando deveria passá-los ao pretérito perfeito do indicativo, conforme o advérbio temporal 'antigamente' exigira.

Ainda no final desse trecho selecionado, percebemos que o informante apresenta um problema com o morfema gramatical precoce, 'falar com', que, em um dos exemplos anteriores, não havíamos verificado, o que comprova que, de fato, não é o PB a língua aceita como $\mathrm{ML}$ no grupo Gavião, uma vez que não há 
regularização de regras de uso, passíveis de aquisição em idade anterior a sete anos.

Assim, concluímos a discussão sobre sociocognição, linguagem e aquisição de PB como L2 pelos Pykobjê-Gavião. No capítulo seguinte, trataremos sobre os estudos linguísticos, que antecedem esta Tese. 


\title{
5. Estudos prévios sobre o Pykobjê-Gavião (Timbira)
}

\begin{abstract}
A ciência de uma língua é apenas uma amostra dentro da ciência das línguas. Por sua vez, a ciência das línguas, comparativa por sua própria natureza, está correlacionada com a ciência da linguagem, que busca descobrir leis linguísticas gerais. Uma disciplina implica ou pressupõe a outra. A tipologia linguística é uma interferência da ciência das línguas para a ciência da linguagem. (JAKOBSON, 2008 [1958], p. 55)
\end{abstract}

Desde o primeiro contato desse povo com os cöpẽ, ocorrido em meados do século XVIII (NIMUENDAJU, 1946), três pesquisas foram apresentadas à comunidade acadêmica, sendo duas delas empreendidas pela Prof ${ }^{\mathrm{a}}$. Dra. Rosane de Sá Amado, sob orientação do Prof. Dr. Waldemar Ferreira Netto, ambos ligados à Universidade de São Paulo.

A primeira (SÁ, 1999) tratou da descrição e análise do sistema fonológico do Pykobjê-Gavião. A autora observou, dentre outras coisas, as unidades distintivas, a estrutura da sílaba e o padrão acentual desse dialeto Timbira.

Por meio desse trabalho, sabemos que o Pykobjê-Gavião conta com onze consoantes, sendo duas delas os glides $\mathbf{w}$ e j , e dez vogais, sete orais e três nasais, conforme vemos nos quadros abaixo (SÁ, 1999, p. 10-11):

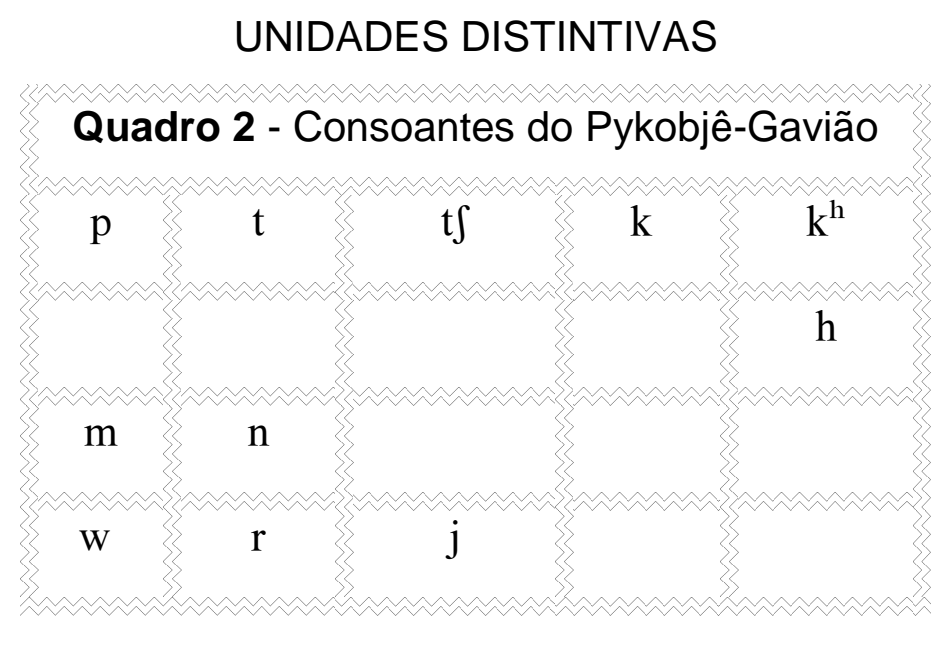

Quadro 3 - Vogais orais do Pykobjê-Gavião

$\begin{array}{lll}\mathrm{i} & \dot{\mathrm{i}} & \mathrm{u} \\ \mathrm{e} & \partial & \mathrm{o}\end{array}$


Quadro 4 - Vogais nasais do Pykobjê-Gavião

$\begin{array}{lll}\tilde{\mathrm{e}} & \tilde{\partial} & \tilde{o}\end{array}$

Além das unidades distintivas, Sá (1999, p. 35-38) nos apresentou o quadro fonético-articulatório de consoantes e vogais do Pykobjê-Gavião. Segundo a autora, há dezoito sons consonantais e vinte e quatro sons vocálicos, sendo oito deles nasais, conforme vemos no quadro abaixo, copiado ipsis litteris da dissertação discutida (SÁ, 1999, p. 35).

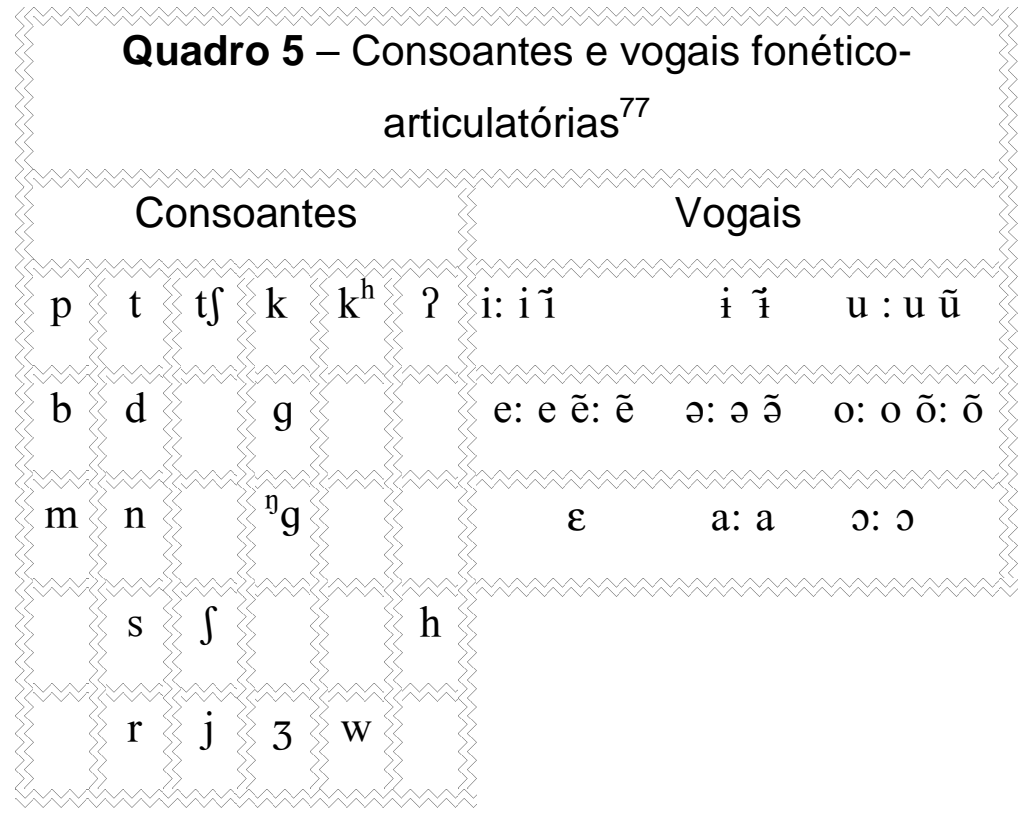

Ao longo de nossa pesquisa em campo, pudemos atestar o uso de todas as consoantes e vogais não distintivas apontadas acima, sem novas contribuições nesse aspecto.

Sobre a estrutura silábica (estudo baseado em SELKIRK, 1982, apud COLLISCHONN, 1996, e na tese de ITÔ, 1986), Sá (1999, p. 12-24) explicou que o Pykobjê-Gavião é uma língua que segue ordenamento fonológico da direita à esquerda para formar um dos seguintes tipos silábicos, verificados na língua falada: CV, CVC, VC (apenas em início de palavra) e $V$ (realização fonológica como $V_{\text {: }}$, apenas em início de palavra).

\footnotetext{
77 Ao longo deste estudo, Sá (1999) também abordou o efeito conhecido como breathy voice (efeito murmurado), que é um diacrítico cultural dos Pykobjê-Gavião em relação aos demais povos Timbira. No estado atual, o breathy voice não tem caráter distintivo
} 
$\mathrm{O}$ ataque pode ser complexo e formado por obstruinte + aproximante, restringindo a sequência de dois elementos com mesmo ponto de articulação (" $\left.\mathrm{pw},{ }^{*} \mathrm{tr},{ }^{*} \mathrm{t} f \mathrm{r},{ }^{*} \mathrm{tj},{ }^{*} \mathrm{t} f \mathrm{j},{ }^{*} \mathrm{mw},{ }^{*} \mathrm{mr},{ }^{*} \mathrm{mj},{ }^{*} \mathrm{nw},{ }^{*} \mathrm{nr},{ }^{*} \mathrm{nj},{ }^{*} \mathrm{hw},{ }^{*} \mathrm{hr},{ }^{*} \mathrm{hj}\right)$. Por outro lado, a coda não é complexa. As consoantes que podem ocupar essa posição são: glides, nasais e [-soante] / [-contínua]. Já o núcleo tende a ser simples e vocálico, com exceção para a modalidade de sílaba $V$. Nesse caso, a única vogal, que também é núcleo, se manifesta como V:. A autora frisou, ainda, que o Pykobjê-Gavião privilegia a sílaba fechada CVC, o que fica mais evidente nos casos de palavras emprestadas do Português (exemplos: 't $\int a j$ para 'saia', 'rit para 'rede' e t $\int a$.'rãp para 'sarampo'). Para simplificar a exposição, pode-se dizer que o padrão silábico máximo do Pykobjê-Gavião é: $\mathrm{C}(\mathrm{C}) \mathrm{V}(\mathrm{C})$, com predominância de sílabas CVC. Apresentamos abaixo a estrutura silábica máxima possível:

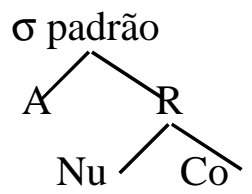

Em que A significa Ataque e $\mathbf{R}$ indica a Rima, que pode ser formada por $\mathbf{N u}$, o Núcleo, e Co, a expressão para Coda.

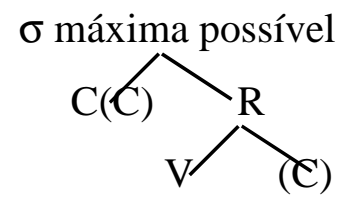

Sá (1999, p. 25-33) estudou o acento com base na teoria métrica clássica da árvore, na teoria da grade métrica (HALLE; VERGNAUD, 1987) e na teoria rítmica assimétrica (HAYES, 1995). Segundo Hayes (1995), o Pykobjê pode ser definido como uma língua de pé métrico iâmbico moraico que, no entanto, parece não ser sensível ao peso silábico, já que boa parte de seus dissílabos oxítonos apresenta sílaba pesada à esquerda e não à direita. Segundo a autora, o pé é construído da direita para a esquerda (em alguns casos é iterativo), com dominância à direita. Dadas algumas exceções, pode-se dizer que o acento no Pykobjê-Gavião é previsível (oxítono) e de caráter delimitativo (fronteira de palavra).

Sá (1999) apresentou, ainda, uma discussão sobre a manifestação fonéticofonológica dos pronomes dessa língua, a qual será retomada e ampliada em seu 
segundo estudo, para título de doutoramento (AMADO, 2004), que tratou, especificamente, das classes de palavras do Pykobjê-Gavião, sob viés morfofonológico.

Amado (2004) tomou como principal objetivo descrever e analisar os processos fonológicos que envolvem fronteiras mórficas, de modo a ampliar questões introduzidas em Sá (1999), dentre elas, a mudança de formas verbais em breves e longas; o caso do alongamento vocálico; a alternância entre h e t $\int$; e, processos de silabificação envolvendo a classe dos pronomes.

Utilizando modelos tipológico-funcionalistas para descrição de línguas e autores como Jensen (1990), Anderson (1985), Bybee (1985) e Schachter (1985), a autora descreveu as classes de palavras do Pykobjê-Gavião a partir da distinção entre classes abertas (palavras com significado lexical) e classes fechadas (palavras com significado gramatical). Para contrapor sua análise, trouxe descrições de outras línguas indígenas do mesmo grupo Timbira (POPJES; POPJES, 1986; SOUZA, 1990 e 1997; FERREIRA, 2003; ALVES, 1999; OLIVEIRA, 2003) ${ }^{78}$, línguas da Família Jê (BORGES, 1996; SANTOS, 1997; SALANOVA, 2001; DOURADO, 1993 e 2001), uma língua da Família Karajá (RIBEIRO, 1996, 2002a e 2002b) e uma língua do Tronco Tupi-Guarani (SEKI, 2000).

No que se refere à classe dos nomes, Amado (2004, p. 36-38) descreveu a existência de três morfemas, dois de grau (aumentativo e diminutivo) e um de plural, além disso, analisou a relação de posse nominal (alienavelmente possuído versus inalienavelmente possuído).

Ao tratar do verbo, Amado (2004, p. 99-128) discutiu a alternância entre formas longas e formas breves, e separou os membros dessa classe em verbos transitivos e verbos intransitivos. Os intransitivos foram, então, subdivididos em "verbos ativos" e "verbos estativos", com base na noção semântica de volição do sujeito. Além disso, descreveu-se a relação de tempo do Pykobjê-Gavião, classificada como futuro versus não futuro.

Sobre o adjetivo e o advérbio, Amado (2004, p. 40,41) afirmou que ambas são classes ainda pouco estudadas nessa língua, todavia apontou como

\footnotetext{
78 Amado (2004) trata o Apinajé como uma variante Timbira. Nessa análise, seguindo Rodrigues (2002), consideraremos o Apinajé como uma língua mais aparentada com o Grupo Kayapó, sabendo que Kayapó e Timbira são variedades linguísticas bastantes próximas, em comparação com as demais existentes na Família Jê.
} 
característica do adjetivo portar termos de classe e ponderou que os advérbios atuam como "modificadores de categorias que não envolvam nomes".

$\mathrm{Na}$ classe dos prefixos relacionais, Amado (2004, p. 50-98) trouxe um breve levantamento de outras línguas indígenas que também apresentam o que parece ser um prefixo relacional, analisando a alternância verificada entre duas ou mais formas, em que uma delas costuma ser o morfema zero $\{\varnothing\}$, com base na relação de contiguidade versus não-contiguidade (RODRIGUES, 2000). Na mesma seção, descreveu os pronomes do Pykobjê-Gavião, que dividiu em três grupos: pronomes enfáticos, pronomes com forma livre (independente) e pronomes com forma presa (dependente). Para todos os casos pronominais, mostrou alguns contextos de uso.

Amado (2004, p. 42-46) descreveu, ainda, algumas posposições e partículas. Como posposições, as marcas de Caso ergativo, te, e dativo, mỹ, e o locativo, kym. Como partículas, a negação, nee... noore, negação e futuro, wyyr, topicalização, my, diretivo, instrumental e causativo, to, plural, mẽ, interrogativo, tem, e, as marcas de presente imediato, cormy, e durativo, ry'my'79.

Por fim e não menos importante, Amado (2004, p. 46-48) apresentou a hipótese de o Pykobjê-Gavião ser uma língua em que há termos de classes. Para fundamentar sua argumentação, elencou alguns exemplos de possíveis membros dessa classe de palavras, tais como, \{he\}, que significaria 'osso', e \{kõn\}, 'ligamento'. Essa proposta foi levada adiante por Silva, durante sua iniciação científica (20072008), e publicada por Amado e Silva (2009).

Já Silva (2012) trouxe uma contribuição morfossintática para as classes de palavras do Pykobjê-Gavião. Seguindo a mesma perspectiva teórica que guiou Amado (2004), isto é, o funcionalismo tipológico, a autora descreveu e analisou as relações entre as partes do discurso do Pykobjê-Gavião, a partir da distinção entre nomes e verbos, que tem se mostrado uma constante entre as línguas naturais. $E$, tomando sentenças simples ou não complexas, descreveu a ordem canônica do Pykobjê-Gavião como sendo APV (DRYER, 1992; PAYNE, 1997).

A categoria nome foi analisada a partir da distinção entre propriedades distribucionais e propriedades estruturais, conforme proposto por Payne (1997, p. 33). Então, retomou os sufixos de grau (\{te\}, aumentativo, e $\{$ re $\}$, diminutivo)

\footnotetext{
${ }^{79}$ Estamos utilizando aqui a escrita da Grafia Uniformizada e não a fonológica, adotada em Amado (2004). O intuito é familiarizar o leitor com os vocábulos que serão retomados ao longo desse estudo.
} 
descritos por Amado (2004), bem como as marcas morfológicas de sexo: cahỹj, para fêmea, e hõmre, para macho. Discutiu o uso do plural, com me ou catëë jë, e do coletivo com jë. Também, apresentou, brevemente, a posse, distinguindo nomes alienáveis de inalienáveis (PAYNE, 1997, p. 41). E, por fim, apresentou a coordenação dentro do sintagma nominal.

No que diz respeito aos verbos, apresentou uma separação entre predicado nominal (N) e verbo-adjetival (VA). Sobre os predicados verbo-adjetivais (VA), foram propostos os subtipos: verbo intransitivo simples (ativo (Sa), estado (So), processo (Sio)), verbo intransitivo estendido (apenas ativo (Sa)), verbo transitivo simples e verbo transitivo estendido.

Sobre operadores, que determinam lexicalmente 0 aspecto, a autora destacou: futuro imediato (awca'te), futuro distante (an cỹm), passado recente (e’no’ny), passado 'há poucos dias' (e’no’cỹm), passado remoto (mam), presente durativo (ry'my'), presente incompleto (ry'hy, cahör) e presente semi-completo (cormy), ao que propôs a hipótese de que seria o presente completado o tempo/aspecto default. Isso será revisto nesta Tese.

Além disso, Silva (2012) discutiu: termo de classe, partícula, prefixo relacional, advérbio e conjunção.

Para embasar o presente estudo, gostaríamos de ressaltar as contribuições de Amado (2004) e Silva (2012), no que se refere, sobretudo, aos pronomes identificados em Pykobjê-Gavião. Retomaremos, então, os três quadros propostos por Silva (2012, p. 110, 111): 


\begin{tabular}{|c|c|c|c|c|}
\hline \multicolumn{5}{|c|}{ Quadro 6 - Pronomes dependentes ${ }^{80}$} \\
\hline & Sujeito & Objeto Direto & Objeto Indireto & Marca de Genitivo \\
\hline $1^{\text {a }} \mathrm{sg}$. & ẽj- & ẽj- & ẽj- & ẽj- \\
\hline $2^{\mathrm{a}} \mathrm{sg}$ & aa- & aa- & aa- & aa- \\
\hline $3^{\mathrm{a}} \mathrm{sg}$. & e'- / Ø- / co- & e'- / Ø- & $\mathrm{CO}-$ & e'- / Ø- \\
\hline 1 a pl. & me ẽj- & me ẽj- & me ẽj- & me ẽj- \\
\hline inclusivo & & & & \\
\hline 19 pl. & me ẽj- & me ẽj- & me ẽj- & me ẽj- \\
\hline exclusivo & & & & \\
\hline $2^{\mathrm{a}} \mathrm{pl}$. & me aa- & me aa- & me aa- & me aa- \\
\hline $3^{\mathrm{a}} \mathrm{pl}$. & me e'- / me Ø- / me co- & me e'- / me Ø- & me co- & me e'- / me Ø- \\
\hline
\end{tabular}

\begin{tabular}{|c|c|}
\hline \multicolumn{2}{|c|}{ Quadro 7 - Pronomes independentes } \\
\hline $1^{\mathrm{a}} \mathrm{sg}$ & wa \\
\hline $2^{\mathrm{a}} \mathrm{sg}$ & ca \\
\hline $3^{\mathrm{a}} \mathrm{sg}$ & cë / Ø \\
\hline 1a pl. inclusivo & wa me \\
\hline $1^{\text {a }}$ pl. exclusivo & co me \\
\hline $2^{\mathrm{a}} \mathrm{pl}$. & ca me \\
\hline $3^{\mathrm{a}} \mathrm{pl}$. & a me / Ø me \\
\hline
\end{tabular}

\footnotetext{
${ }^{80}$ Apresentamos o paradigma de PD de acordo com a distribuição morfossintática que se observa. Os demais pronomes não parecem sofrer qualquer influência determinada por contexto morfossintático, por isso não julgamos relevante distinguir seus usos por função sintática.
} 
Quadro 8 - Pronomes enfáticos

\begin{tabular}{|c|c|}
\hline $1^{\mathrm{a}} \mathrm{sg}$ & $\mathrm{pa}^{81}$ \\
\hline $2^{\mathrm{a}} \mathrm{sg}$ & $\mathrm{ca}$ \\
\hline $3^{\mathrm{a}} \mathrm{sg}$ & ta \\
\hline $1^{\mathrm{a}} \mathrm{pl}$. inclusivo & me paa \\
\hline $1^{\mathrm{a}} \mathrm{pl}$. exclusivo & me paa \\
\hline $2^{\mathrm{a}} \mathrm{pl}$. & $\mathrm{me} \mathrm{ca}$ \\
\hline 3ㄹ. & me ta \\
\hline
\end{tabular}

Tendo feito essa breve retomada das temáticas, que já percorremos na descrição e análise do Pykobjê-Gavião, passaremos às discussões relacionadas às noções de tempo, aspecto e modalidade, em Pykobjê-Gavião.

\footnotetext{
${ }^{81}$ Concordamos que a $1^{\text {a }}$ pessoa do sg. manifesta-se foneticamente tal qual Amado (2004) descreveu, no entanto, parece que sua contraparte plural apresenta alongamento vocálico.
} 


\section{Discutindo tempo}

Geralmente, no entanto, a noção de tempo, com relação à qual agora pode ser explicado, não é uma linha do tempo metricamente ordenada. Tome a seguinte comparação para entender a relação entre uma noção corriqueira de tempo e agora, como momento da fala ou da escrita. Um córrego amplo de tempo, com variadas velocidades de fluxo, carrega rio abaixo uma tábua de madeira, que pode variar em tamanho e cuja borda é difusa. Essa tábua pode ser comparada ao tempo da fala e ela carrega consigo rio abaixo 0 falante (e o ouvinte). ${ }^{82}$ (PAPROTTÉ, 1988, p. 460, tradução nossa)

Conforme já salientado em Silva (2012), nome e verbo não são tomados aqui como categorias em oposição, antes sinalizam uma continuidade, em que o verbo mais prototípico se distinguiria do nome mais prototípico ao fomentar relações (LANGACKER, 1987 apud SCHACHTER, 2007; WIERZBICKA, 1986 apud SCHACHTER, 2007)

Fillmore $(1976,1977)$ sugere que, na mente do NLU, os nomes ativam frames, ao passo em que os verbos ativariam scripts, convertidos em scenes. Frame, script e scene dizem respeito a estruturas mentais idealizadas para entender como a mente humana categorizaria as experiências e conhecimentos adquiridos, o que também pode ser entendido como "estágios discursivos". Assim, cada palavra representa uma categoria de experiências. Por exemplo, "cadeira" pode carregar consigo "mesa" e "comida", e isso configuraria um frame, por isso os dicionários tradicionais tendem a se apresentar como ferramentas de pouca relevância prática para quem desconhece uma língua. Já o script seria uma forma particular de frame, que introduz um conjunto potencialmente dinâmico de eventos e situações, como "sentar para comer".

Givón (2001, p. 50-52), por sua vez, afirma que os verbos estão no ponto mais baixo do traço "estabilidade temporal" (temporal stability), enquanto que os nomes ocupam o ponto mais alto dessa mesma escala ${ }^{83}$. Givón (2001) cita, ainda, outros traços semânticos que julga relevantes para distinguir, sobretudo, nomes de verbos: "compactação temporal" (temporal compactness), "complexidade e difusão

\footnotetext{
${ }^{82}$ Texto original: "Generally, however, the notion of time with respect to which now can be explained is not that of a metrically ordered time line. Imagine rather the following comparison to hold between an everyday notion of time and now, the moment of speech or writing. A broad stream of time with varying speeds of flux carries downstream a wooden board which can vary in size and which has fuzzy edges. This board can be likened to speech time and it carries downstream with it the speaker (and the hearer)."

${ }^{83}$ Givón (2001, p. 50) afirma que o traço "estabilidade temporal", é, de fato, o mais importante para distinguir nome e verbo, chamando-o de "primus inter pares".
} 
espacial" (complexity and spatial diffuseness), "concretude" (concreteness) e "agentividade e atividade mental" (agentiveness and mental activity). Desse modo, na parte mais universal da escala, o protótipo verbal apresentaria os seguintes traços: [-estabilidade temporal, +compactação temporal, +complexidade e difusão espacial, +concretude, +agentividade e atividade mental] ${ }^{84}$.

Como o verbo prototípico dispõe [-estabilidade temporal], podemos buscar a distinção de tempos verbais (COMRIE, 1985), e, por ter como característica [+compactação temporal], é possível buscarmos marcações aspectuais (COMRIE, 1976). Todavia, nem tempo nem aspecto são características relacionadas aos verbos, em todas as línguas naturais. Sobre isso, Corôa (2005), discute:

\begin{abstract}
Mas a categoria temporal não está universalmente ligada ao verbo, nem este a ela. Klein (1974) cita, por exemplo, o vietnamita e o birmanês, que não têm formas verbais marcadas por morfemas temporais e são, no entanto, línguas perfeitamente capazes de expressar um instante ou um sistema temporal completo. No vietnamita, por exemplo, a situação e/ou contexto especificam a relação temporal em ação. O hopi, língua ameríndia estudada por Whorf (1971), não marca em suas formas verbais a distinção entre passado, presente e futuro, mas marca, flexionalmente, a expectativa da ação (a cultura hopi dá muito valor à preparação) e a regularidade do evento. Segundo Klein (1974), o alemão tem categorias verbais que têm a ver com o tempo; é, entretanto possível usar-se um verbo sem tais categorias a ele ligadas. (CORÔA, 2005, p. 16)
\end{abstract}

Comrie (1976, p. 01, 02) define a noção de tempo como algo que "relaciona o tempo de uma situação dada a algum outro tempo, geralmente o do momento da fala. ${ }^{85 " ~ E n t a ̃ o, ~ p r o p o ̃ e ~ h a v e r ~ d u a s ~ f o r m a s ~ c o n c e i t u a l m e n t e ~ d i s t i n t a s ~ p a r a ~ m a r c a r ~} 0$ tempo nas línguas naturais: tempo absoluto (subdividido em passado, presente e futuro) e tempo relativo (particípio presente ou particípio passado), conforme o quadro 9 indica. $E$ tanto um quanto o outro podem não estar gramaticalmente marcados.

\footnotetext{
${ }^{84}$ Lembrando que quando usamos '+' ou '-' para distinguir os traços, não estamos pensando em presença $v s$ ausência do mesmo, mas de maneira escalar, em que '+' significa 'em grau mais alto' e '-' significa 'em grau mais baixo' de uso. Para entender melhor como cada um dos traços apresentados opera, sugerimos a leitura de Givón (2001).

${ }^{85}$ Texto original: "[...] relates the time of the situation referred to to some other time, usually to the momento $f$ speaking."
} 


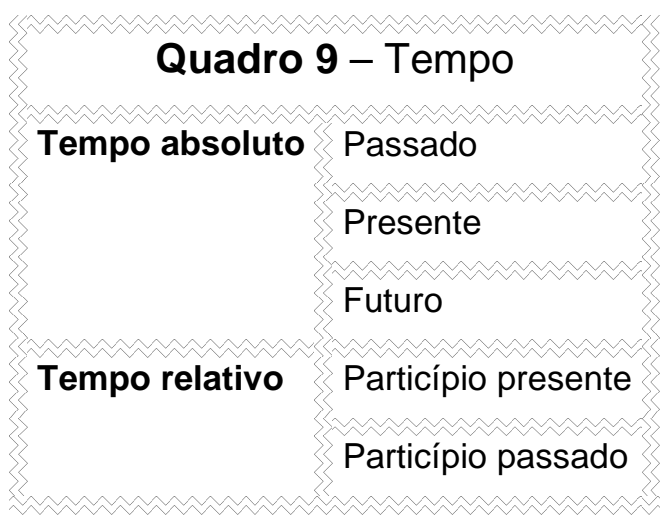

Com relação ao aspecto, Comrie (1976, p. 03) o define como "diferentes modos de enxergar a consistência temporal interna de uma situação. ${ }^{86 " ~} \mathrm{E}$ sua proposta de análise separa perfectivo (ou aoristo) e imperfectivo.

O imperfectivo pode, ainda, ser subdivido em habitual e contínuo (progressivo ou não progressivo), conforme indicado no quadro 10 . E, assim como algumas línguas não apresentam marcação gramatical para referir os tempos do discurso, é possível, também, que as línguas naturais não marquem distinções semânticas do aspecto.

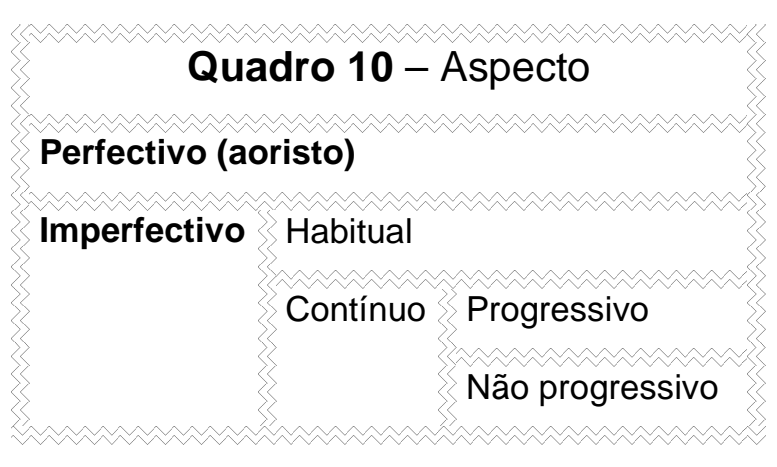

Desse modo, Comrie (1976, p. 05) assinala que a diferença entre tempo e aspecto está na percepção de que o tempo é uma categoria dêitica, que pontua situações em um tempo relacionado, em geral, ao presente; ao passo em que o aspecto remete à consistência temporal interna de uma situação. Nas palavras do autor, "poder-se-ia situar a diferença como sendo a de que em um é o tempo da situação-interna (aspecto) e no outro é o tempo da situação externa (tempo) ${ }^{87}$."

Corôa (2005, p. 13) também propõe que a principal distinção entre tempo e aspecto diga respeito à possibilidade dêitica: "Tempo e aspecto são dados como

\footnotetext{
${ }^{86}$ Texto original: "[...] 'aspects are different ways of viewing the internal temporal constituency of a situation."

${ }^{87}$ Texto original: "[...] one could state the difference as one between situation-internal time (aspect) and situation-external time (tense)."
} 
duas categorias distintas, mas solidárias, ambas apoiadas na noção de tempo, mas sendo aquela dêitica e esta não dêitica."

Retomando a discussão proposta por Fillmore (1976, 1977), não seria equivocado afirmarmos que o aspecto está intimamente relacionado à semântica cognitiva, enquanto que o tempo transborda à pragmática e usos da fala. E, por sua vez, uma instância se fundamenta na relação com a outra.

Levinson (2007, p. 89), ao tratar da dinâmica dêitica entre tempo e espaço, ressalta a dificuldade de abordar essas categorias, uma vez que, embora possam ser entendidas como uma relação não submetida à percepção interna de mundo, ambas guardam forte interação com a organização semântica de tempo e espaço.

Lyons (1977), ao se dedicar, mais profundamente, à distinção entre dêixis de tempo e de espaço, afirmara que a dêixis de espaço é mais fundamental do que a dêixis de tempo, porque, em geral, esta derivaria daquela. Em nosso trabalho de campo, ratificamos essa conceitualização, pois muitos marcadores lexicais de tempo poderiam ser, literalmente, transcritos como marcas dêiticas de espaço, conforme abaixo:

1. wa ha cö cỹm tep cwyr 1PI IRR água LOC peixe pegar 'Pegarei peixe no rio'

2. an cỹm wa ha cato ano LOC 1PI IRR partirINTR

'Dentro de alguns anos irei embora'

3. ?an ny wa ha cato ano PT 1PI IRR partirINTR 'Dentro de alguns anos irei embora'

Ao contrastar os exemplos oferecidos acima, entendemos que, mesmo com o empréstimo de um léxico que, em PB sincrônico, marca dêixis de tempo ('ano'), os Gavião preferem seu uso atrelado a uma partícula locativa (ex. 2 em contraponto ao ex. 3).

Mais especificamente sobre a dêixis de tempo, Levinson (2007, p. 89) afirma que "a dêixis de tempo faz referência em última análise ao papel do participante." Ou 
seja, a dêixis de tempo estaria mais relacionada a uma semântica cognitiva do que ocorreria com a dêixis de lugar, conforme Fillmore $(1976,1977)$ buscou evidenciar em seus estudos.

Desse modo, para distinguir as referências de tempo, indicadas em um enunciado, seria necessário marcar o momento do discurso (moment of speech), que Comrie $(1985)^{88}$ abrevia por S, e nós utilizaremos como S', e momento do evento (moment of event ${ }^{89}$ ), indicado como $\mathrm{E}$ no livro base, e $\mathrm{E}$ ' aqui.

Assim, para o tempo absoluto, Comrie (1985, p. 123) propõe:

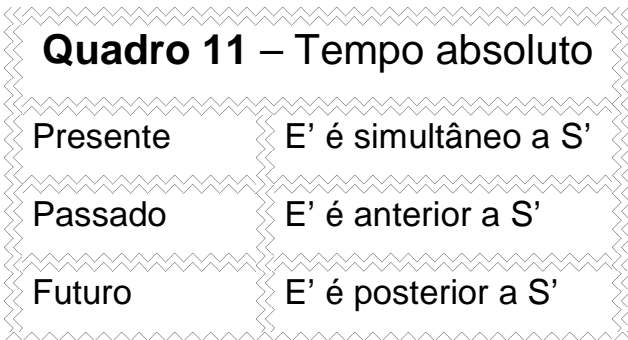

Já o tempo relativo, indica uma relação entre o momento do Evento ( $\left.E^{\prime}\right)$ e o tempo que é dado em um ponto de referência (reference point), a que denominaremos R' e o autor denomina R. R', ao contrário de S', não está ancorado em um centro dêitico, mas em um contexto de fala. Ou seja, R' é mais anafórico enquanto S' é mais dêitico. Para o tempo relativo, Comrie (1985, p. 124, 125) estabelece:

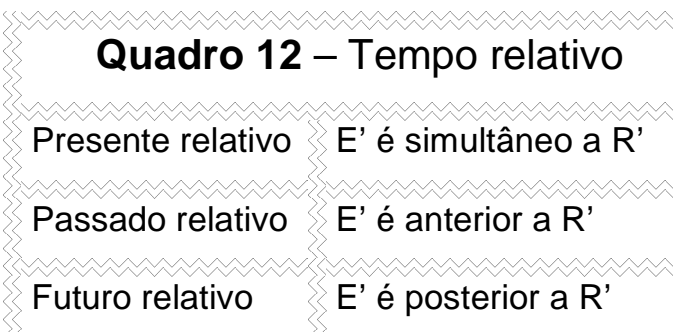

A fim de comparar tempo absoluto e tempo relativo, Côroa (2005) explica que há certos impasses, ao se considerar o tempo relativo, ao contrário do que ocorre com o tempo absoluto (default em relação ao relativo). Em suas palavras:

\footnotetext{
${ }^{88}$ Comrie está dialogando com Reichenbach, que propôs olhar para a temporalidade expressa pelo verbo, a partir de três pontos temporais: o momento da fala (MF), o momento do evento (ME) e o momento da referência (MR). ${ }^{89}$ Sobre isso, Comrie (1985, p. 122) ressalta que não se deve restringir E à percepção semântica de evento, antes deve ser entendido como um indicativo para situações em geral.
} 
A principal diferença, então, entre teorias de tempo absoluto e teorias de tempo relacional está, respectivamente, na existência ou não de um conjunto de momentos. Em uma teoria absoluta, o momento em que o evento ocorre é suficiente para individualizá-lo; em uma teoria relacional, como não existem momentos distintos, não podemos individualizar o evento segundo o momento. Embora a aplicação prática das teorias relacionais esbarre em muitas dificuldades, acarretando, principalmente, a circularidade semântica, elas nos "comprometem com menos verdades conceituais, pois são mais flexíveis e não proíbem rupturas com nossas maneiras de falar." (Lacey, 1972:119). (CÔROA, 2005, p. 28)

Conforme já havíamos salientado antes, o tempo pode não ser marcado semântica ou teoricamente em uma língua, o que Levinson (2007, p. 94) entende como ausência de "tempo verbal L" (de língua). O tempo L, por sua vez, distingue-se do "tempo verbal M" (metalinguístico), sendo este mais dêitico e empírico e aquele mais ligado à morfossintaxe. Contudo, o autor ressalta que o tempo $L$ será tanto mais funcional, à medida que mantiver uma relação estreita com o tempo $\mathrm{M}$.

Aplicando suas observações às línguas naturais, Levinson (2007) dialoga com outros teóricos para explicitar as relações, que observamos em línguas como o Pykobjê-Gavião:

Às vezes, afirma-se que há línguas sem tempos verbais verdadeiros, por exemplo, o chinês ou o ioruba, e isto é correto no sentido de que tais línguas não têm tempos $L$ morfologicamente marcados no verbo ou mesmo sistematicamente em outras áreas da morfologia (...). Podemos, porém, supor com confiança que não existem línguas nas quais parte de um sistema de tempos verbais $M$ não seja concretizada em algum lugar nos adjuntos adverbiais de tempo ou assemelhados (...). (LEVINSON, 2007, p. 96)

O Pykobjê-Gavião, portanto, parece ser um tipo linguístico que não dispõe de tempo L, morfossintaticamente marcado. Contudo, isso não significa ausência de tempo $\mathrm{M}$, que tende a ser disposto por meio de itens lexicais. Abaixo, traremos uma discussão sobre tempo absoluto e alguns itens lexicais de uso atestado:

\subsection{Tempo absoluto}

- Sobre o tempo presente, Comrie (1985) esclarece:

Em particular, o tempo presente é usado para falar de estados e processos que se detêm no momento presente, mas que começaram antes do momento presente e podem muito bem continuar ao longo do presente, 
como em a Torre de Babel fica em Paris e o autor está trabalhando no capítulo dois. ${ }^{90}$ (COMRIE, 1985, p. 37, tradução nossa)

No Pykobjê-Gavião, para indicar presente, o mais comum é usar ry'my', que, por sua vez, apresenta aspecto habitual (imperfectivo). Comrie (1985, p. 39) relaciona o tempo presente ao habitual, explicando que "o hábito se sustenta no momento presente, e é por isso que o presente é, em princípio, um tempo

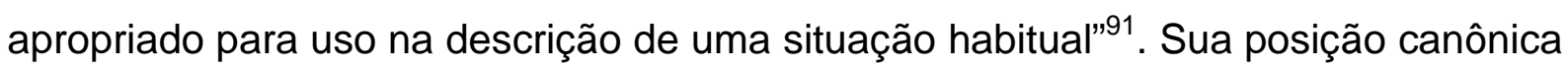
é em início de frase:

4. ry'my' ẽjcre enta xët

HAB casa DEM queimarINTR

'Essa/esta casa está queimando'

5. ry'my' cë cö ẽ'-pẽn

HAB 3PI água 3PD-beber

'Ele está bebendo água'

Se o contexto de fala estiver explicitado, de modo que fique claro ao interlocutor que E' é simultâneo a S', a frase pode ser dita sem uso de qualquer marca:

6. ẽjcre enta xët

casa DEM queimarINTR

'Essa/esta casa está queimando'

7. cë cö ẽ'-pẽn

3PI água 3PD-beber

'Ele está bebendo água’

Nesse ponto, parece que Canela e Gavião (incluso o Parkatêjê) estão em sintonia.

Sobre o presente em Canela, Alves (2008, p. 02) explica que "A categoria temporal 'presente', em termos de gram-types (Bybee \& Dahl 1989), é não marcado

\footnotetext{
${ }^{90}$ Texto original: "In particular, the present tense is used to speak of states and processes which hold at the present moment, but which began before the present moment and may well continue beyond the present moment, as in the Eiffel Tower stands in Paris and the autor is working in chapter two."

${ }^{91}$ Texto original: "[...] the habit does hold at the presente moment, and that is why the presente tense is in principle an appropriate tense to use in describing this habitual situation."
} 
em Canela".

- Comrie (1985) propõe o entendimento de tempo passado, como sendo:

O sentido de passado é, portanto, localização antes do momento presente, e quaisquer outras deduções sobre a localização temporal, que são feitas com base em sentenças individuais no passado, são o resultado de outros fatores, tais como simplesmente a escolha do tempo. ${ }^{92}$ (COMRIE, 1985, p. 41 , tradução nossa)

Para indicar passado (informação empírica: passado recente), o mais difundido é e'no'ny. Pode ser tomado adverbialmente com o sentido de 'ontem'. Se em posição inicial, com escopo sobre toda a sentença, o uso da posposição de tempo, $\{$ ny\}, é facultativo:

8. e'no'ny hõmre ngõr pex

PAS/LEX homem dormirINTR bemADV

'Ontem o homem dormiu bem'

9. e'no'ny ny hõmre ngõr pex

PAS/LEX PT homem dormirINTR bemADV

'Ontem o homem dormiu bem'

10. empo aa-te e'no'ny ny coco?

WH 2PD-ERG PAS/LEX PT comer

'O que você comeu ontem?'

11. ?empo aa - te e'no'ny coco?

WH 2PD-ERG PAS/LEX comer

'O que você comeu ontem?'

Para indicar um passado, com referência de 'há poucos dias atrás', usa-se e’no'cỹm. Por já estar acompanhado de uma partícula locativa, \{cỹm\}, \{ny\} não é requerido.

\footnotetext{
${ }^{92}$ Texto original: "The meaning of the past tense is thus location in time prior to the present moment, and any further deductions about temporal location that are made on the basis of individual sentences in the past tense are the result of factors other than simply the choice of tense."
} 
12. e'no'cỹm aa-te a'tor coran

PAS/LEX 2PD-ERG lambu matar

'Há poucos dias você matou lambu'

Acreditamos que e'no'ny e e'no'cỹm partilhem da mesma raiz primitiva, e'no. No estado sincrônico do Pykobjê-Gavião, e’no pode ser usado como quantificador nominal indefinido, com o sentido de 'algum pedaço de', como vemos na frase abaixo:

13. ẽj-mỹ e'no cwyr j-acree 1PD-DAT QI mandioca PR-escolher

'Vou escolher alguma mandioca para mim'

Literalmente: 'Para mim, uma parte das mandiocas, eu escolho'

Contexto: Há várias mandiocas e dentre elas, escolherei a(s) que mais me apetece $(\mathrm{m})$.

E'no também pode ser usado como verbo, no sentido de 'dar uma parcela, um pouco', como veremos abaixo:

14. ẽj-mỹ cwyr to e'no!

1PD-DAT mandioca IMP dar(parte do todo)

Literalmente: 'Para mim, dê um pedaço de mandioca!'

Contexto: Alguém está comendo uma mandioca e o falante deseja comer um pouco daquele prato.

Assim, nossa hipótese é de que e'no, por apresentar frame (ex. 13) ou script (ex. 14), que remeteria à dêixis de espaço, teria sido apropriado para dêixis de tempo. Em um primeiro momento, guardando a posposição locativa, \{cỹm\}, conforme indicado em (12). Adiante, por E' anteceder S' com uma distância menor do que a inicial, teria incorporado a posposição de tempo, \{ny\}, como aparece em (08) e (09). E, ao definir escopo apenas sobre o domínio verbal, permitiria, inclusive, redundância morfêmica, em que haveria tanto \{ny\} no lexema, e'no'ny, quanto \{ny\} atuando como posposição de tempo.

Para indicar passado (informação empírica: remoto), usa-se mam, com sentido do nosso 'antigamente', podendo remeter a períodos que compreendem desde 'algumas décadas atrás' até dado 'tempo mítico'. Não é adequado usar 
qualquer marca adverbial depois de mam. Sua posição canônica é em início de frase:

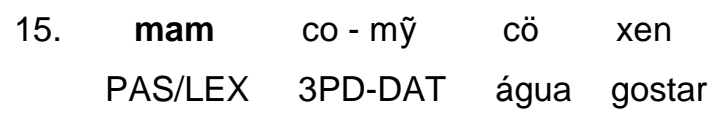

'Antigamente ele gostava de água'

Segundo nossos interlocutores, mam também seria um caso de apropriação da dêixis de lugar para dêixis de tempo, e, indicaria um 'espaço mítico', anterior à criação dos primeiros Gavião (extensão metafórica de tempo). Mam remeteria a algo como o espaço de gestação desses povos, morada da deusa Pykop, que dá nome ao povo. Por isso, sempre que se questionou o estatuto categorial de mam, a narrativa mítica surgiu, de modo a justificar que mam seria antes dêixis de espaço do que uma marcação lexical de tempo, mesmo em estado sincrônico.

Além disso, Amado (2004, p. 99), ao analisar a alternância entre forma breve e forma longa que os verbos apresentam em sua raiz, identifica que o tempo seria uma variável relevante. Segundo a autora, se a indicação for de passado, os verbos apresentariam aquilo que foi denominado "forma longa" (exs. de verbos que alternam forma breve e forma longa: $\operatorname{co}(r)=$ comer, cato $(r)=$ sair/partir). Já se 0 tempo for presente ou futuro, teríamos a "forma breve". Vejamos, então, os exemplos retirados de Amado (2004, p. 100, grifos nossos, glosa original), para entendermos melhor como se processa essa diferenciação, que opera a nível morfofonológico:

16. ej - te aijẽ kor
1 ERG 'carne' 'comer'
'eu comi a carne'

17. awakate wa ha a?jẽ ko

'amanhã' 1 FUT 'carne' 'comer'

'amanhã eu comerei a carne'

18. wa a?jẽ ko

1 'carne' 'comer'

'eu estou comendo a carne' 
Em Gavião Parkatêjê, Freitas (2008. P. 112, ex. 158), ao rever Ferreira (2003), também aponta para uma distinção entre passado recente e passado remoto. Neste dialeto, o passado remoto é marcado por aiku, como em (19):

19. pia aiku apte ita awkapi

Dub PR frust Dem conhecer

'Dizem que ele queria conhecer aquilo'

Em Apaniekrá-Canela, Alves (2008, p. 05) também trata de uma distinção entre passado vívido e não-passado vívido, realçando que "não há, em termos de gram-types, um morfema ou partícula específica que codifique passado recente." Todavia, assim como Pykobjê-Gavião e Parkatêjê-Gavião, há marcação de passado remoto (passado distante), por meio da partícula pe.

- A fim de apresentar o tempo futuro, Comrie $(1985$, p. 43) vai direto ao assunto e afirma que é válido definir "o tempo futuro como a localização de uma situação em um momento posterior ao presente. ${ }^{93,}$

Com relação ao futuro, tanto Levinson (2007, p. 95) quanto Comrie (1985, p. 44) ressaltam ser este o tempo que recebe maior interferência de marcas modais, uma vez que a scene, que envolve o futuro, tende a ganhar contornos distinguíveis, como por exemplo, o modo irrealis do Pykobjê-Gavião, cuja marca é \{ha\}. E seria esta a principal característica, a distinguir tempo futuro dos demais (passado e presente).

No Pykobjê-Gavião, para indicar futuro (informação empírica: imediato), usase awca'te, que na forma adverbial, poderia ser citado como 'amanhã':

20. awca'te wa ha cwyr cor

FUT/LEX 1PI IRR mandioca comer

'Amanhã comerei mandioca'

\footnotetext{
${ }^{93}$ Texto original: "[...] to define future tense as locating a situation at a time subsequent to the presente moment, [...]"
} 
21. awca'te ny cahỹj ha cwyr cor

FUT/LEX PT mulher IRR mandioca comer

'Amanhã a mulher comerá mandioca'

Para indicar futuro (informação empírica: distante), o termo seria an cỹm, que, literalmente, significa 'no espaço de anos'94, como dado abaixo:

22. an cỹm wa ha cato

ano LOC 1PI IRR partirINTR

'Dentro de alguns anos irei embora'

E, conforme já salientado acima, o uso do modal \{ha\} mostra-se obrigatório, sempre que o tempo $\mathrm{M}$ indicar futuro. $\mathrm{O}$ mesmo parece se observar em Canela e Parkatêjê-Gavião, com a diferença de que neste a partícula indicada para o irrealis é $\{k a\}$.

Assim, podemos concluir que, embora o Pykobjê-Gavião não disponha de tempo L, ou seja, marcadores morfossintáticos para indicar cada um dos tempos absolutos, a língua dispõe de "itens lexicais" (lexical itens) e "expressões lexicalmente compostas" (lexically composite expressions), que situam os enunciados em uma dêixis de tempo M. ${ }^{95}$

\subsection{Tempos relativos}

Comrie (1985, p. 63) explica que seria um erro afirmar que tempos relativos só se manifestariam em orações relativas, ao que cita o árabe clássico, que, segundo o autor, seria um exemplo de língua, que apresenta tempo relativo na oração principal. Apesar disso, o autor reconhece que os tempos relativos tendem a

\footnotetext{
${ }^{94}$ Conforme podemos ver pela tradução proposta, não é apenas em Pykobjê-Gavião que indicadores lexicais de espaço servem para formar dêixis de tempo. Em PB, a expressão 'no espaço de...' tende a ser bastante frutífera, ao gerar usos como: 'No espaço de uma vida, deve-se escrever um livro, ter um filho e plantar uma árvore.'

${ }^{95}$ Comrie $(1985$, p. $7,8,9)$ propõe haver três possibilidades de expressões para localização no tempo: expressões compostas lexicalmente, tais como "em alguns dias" e "daqui a muitos anos"; itens lexicais, em que, em estado sincrônico de língua, os falantes identificam apenas um vocábulo, seria o caso de "hoje", "ontem" e "amanhã"; e, por fim, categorias gramaticais (grammatical categories), presentes em línguas flexionais, como o Português. Nessa língua, por exemplo, poderíamos remarcar $\{-\mathrm{v}-\}$, na conjugação do passado (tempo) imperfeito (aspecto): (eu) am-a-v-a- $\emptyset$, (tu) am-a-v-a-s, (ele) am-a-v-a- $\emptyset$, (nós) am-á-v-a-mos, (vós) am-á-v-e-is, (eles) am-a-v-a-m.
} 
se apresentar, na maior parte das línguas naturais, em contexto de sentenças que se relacionam com outras, em condição de encaixadas.

Ressalta, também, que os tempos relativos não devem ser entendidos como uma continuidade do tempo absoluto, indicado na oração matriz, o que seria congruente à definição: "Se o tempo absoluto é passado, então o relativo deve ser passado um pouco mais distante", conforme muito se incorre no ensino da gramática de língua inglesa para falantes de outras línguas.

Para explicar esse raciocínio bastante difundido, Comrie (1985, p. 61) hipotetiza que ele seria resultado da observação de tempos relativos em contexto de narrativas, em que, por força da coerência, os tempos relativos estariam muito próximos, semanticamente, dos tempos absolutos.

Abaixo, retomamos parte da discussão, trazendo as palavras do autor:

\begin{abstract}
Procurando por exemplos de referência de tempo relativo, é essencial assegurar que a interpretação da referência de tempo relativo é antes parte do significado da forma em questão do que uma implicatura derivada, em parte, do contexto. [...] Então, alguém poderia tentar pensar que esse sequenciamento é parte do significado das formas verbais usadas e, portanto, introduzir um sentido para referência de tempo relativo como 'passado imediato' ou 'futuro imediato' (uma vez que definiu a referência de tempo do verbo anterior a partir do verbo que o segue, ou vice-versa). ${ }^{96}$ (COMRIE, 1985, p. 61, tradução nossa)
\end{abstract}

Então, Comrie (1985, p. 58) esclarece que o que, realmente, diferenciaria tempo absoluto de tempos relativos seria o fato de que nestes não haveria uma especificação de que o tempo presente corresponde ao ponto de referência, o que significa que o momento presente é apenas um dentre outros pontos de referência possíveis. A abertura paradigmática acerca do ponto de referência torna, portanto, os tempos relativos mais pragmáticos do que o tempo absoluto, cujo sentido tende a atuar fortemente para sua interpretação.

Tratamos por tempos relativos , porque Comrie (1985) propõe uma divisão entre "tempo relativo puro" (pure relative tense) e "tempo relativo-absolutivo" (absolutive-relative tense). Exemplos de tempo relativo puro seriam as formas de

\footnotetext{
${ }^{96}$ Texto original: "In looking for examples of relative time reference, it is essential to ensure that the relative time reference interpretation is part of the meaning of the form in question, rather than an implicature derived from, in part, the context. [...] Thus, one might be tempted to think that this sequencing is part of the meaning of the verb forms used, thus introducing a meaning of 'immediate past' or 'immediate future' relative time reference (depending on whether one defined the time reference of the preceding verb in terms of the following verb, or vice versa)."
} 
particípio, enquanto que um bom exemplo de tempo relativo-absolutivo seria o mais que perfeito, do Inglês.

Concernente ao tempo relativo puro, o autor distingue três possibilidades de particípio: particípio presente, em que há simultaneidade com o ponto de referência de um tempo x (COMRIE, 1985, p. 59); particípio passado, manifesto se o ponto do tempo de referência for passado em relação a este (COMRIE, 1985, p. 60); e, particípio futuro, em que o ponto do tempo de referência mostra-se como futuro em relação a este (COMRIE, 1985, p. 61).

Por outro lado, o mais que perfeito, em Inglês, exemplifica a dinâmica própria do tempo relativo-absoluto, pois o ponto de referência é passado e, além disso, o enunciado todo está localizado em um tempo anterior ao do ponto de referência, ou seja, essa forma remete a um "passado no passado".

Para concluir essa breve discussão teórica, trazemos, então, um apanhado comparativo entre tempo absoluto, tempo relativo puro e tempo relativo-absoluto, que Comrie (1985) postula:

\begin{abstract}
Até então, nós examinamos tempos com referência de tempo absoluto, em que uma situação está localizada antes, depois ou no momento presente; e tempos relativos, em que uma situação está localizada antes, depois ou no ponto de referência dado contextualmente. [...] Tempos podem ser denominados como relativo-absoluto, desde que seu significado mescle localização de tempo absoluto de um ponto de referência e localização de tempo relativo de dada situação. ${ }^{97}$ (COMRIE, 1985, p. 64, 65, tradução nossa)
\end{abstract}

Em Pykobjê-Gavião, a referência de tempo relativo tende a ser marcada lexicalmente, como o é também no tempo absoluto, mas por meio de relativas.

Sobre o tempo relativo puro, atestamos usos que poderíamos entender como participiais. Em todos os casos, o prefixo relacional parece ser o elemento que marca a relação (de simultaneidade, tempo anterior ou tempo posterior) entre o tempo do evento e o tempo do ponto de referência.

- Particípio presente - o prefixo relacional marca a simultaneidade entre o tempo do evento e o tempo do ponto de referência. Além disso, atestamos o uso de

\footnotetext{
${ }^{97}$ Texto original: "So far, we have examined tenses with absolute time reference, where a situation is located at, before, or after the present moment; and relative tenses, where a situation is located at, before or after a reference point given by context. [...] They may be termed absolute-relative tenses, since their meaning combines absolute time location of a reference point with relative time location of a situation [...]."
} 
[PD+cöt]. Restrito a relativas, toma como posição canônica pós-A e atua como um marcador adverbial, que informa ao destinatário simultaneidade com o ponto de referência de um tempo $x$, conforme indicado abaixo:

23. ca e'-cöt amjõ mỹ ẽ'-cën j-aren

2PI 3PD-PP/LEX REFL DAT 3PD-amar PR-dizer

'Você diz que é amante dela'

Literalmente: 'Você, ao mesmo tempo em que a ama, diz ter amor por ela'

24. aa-te e'-cöt amjõ mỹ ẽ'-cën j-aren

2PD-ERG 3PD-PP/LEX REFL DAT 3PD-amar PR-dizer

'Você dizia que era amante dela'

Literalmente: 'Você, ao mesmo tempo em que a amava, dizia ter amor por ela'

25. ?ca ha e'-cöt amjõ mỹ ẽ'-cën j-aren ${ }^{98}$

2PI IRR 3PD-PP/LEX REFL DAT 3PD-amar PR-dizer

'Você dirá que será amante dela'

Literalmente: 'Você, ao mesmo tempo em que a ama, dirá ter amor por ela'

Observemos que o prefixo relacional concorda com o sujeito da oração matriz, ao passo em que o advérbio \{cöt\} recebe um pronome dependente, que concorda com o PD da relativa.

- Tanto particípio passado quanto o particípio futuro também só foram atestados em relativas. Em ambos os casos, não encontramos qualquer advérbio específico, como seria 0 \{cöt\} para o particípio presente. Portanto, acreditamos que os NLU recorram aos mesmos itens ou expressões lexicais usados em tempo absoluto, para marcar o tempo da matriz. Além disso, ressaltamos a concordância do prefixo relacional, igualmente à verificada no particípio presente.

Exemplo de uso do particípio passado:

\footnotetext{
${ }^{98}$ Por ? queremos dizer que tal frase não costuma ser produzida pela maior parte da comunidade de fala, ainda que possa ser entendida com o auxílio de fatores pragmáticos. Utilizaremos * para dizer que tal frase não faz parte do uso difundido pela maioria da comunidade de fala, o que não quer dizer que a mesma seja totalmente inconcebível ou ininteligível, devido a restrições de qualquer espécie.
} 
26. awca'te wa ha ẽj-tyx ẽj-te amjõ mỹ j-apake xỳ j-aren ${ }^{99}$ FUT/LEX 1PI IRR 1PD-fazer 1PD-ERG REFL DAT PR-discurso PC PR-dizer 'Amanhã, eu terei feito um discurso'

Literalmente: 'Amanhã, eu farei o discurso sobre o qual vinha pensando'

Exemplo de uso do particípio futuro:

27. mam mehẽ me vej te h-aracwa to h-ajẽn xỳ cë ha me ẽj-tyx j-aren PAS/LEX povo PL velho ERG PR-conto CAUS PR-ensinar PC 3PI IRR PL 1PD-fazer PR-dizer 'Minha fala vindoura é sobre as histórias que os velhos me ensinaram' Literalmente: o povo velho, de antigamente, ensinou histórias para que, aos do futuro, eu fizesse fala.

- Por fim, observamos que as elicitações, que buscaram testar a existência de tempo relativo-absoluto, não foram frutíferas, no sentido de destacar uma expressão inovadora. Antes, parece que os NLU preferem o uso de sentenças sem tantos verbos a concorrerem para a interpretação.

Tendo elaborado a presente discussão sobre tempo absoluto e tempos relativos, passaremos à análise de aspectualidade e modalidade, em PykobjêGavião.

\footnotetext{
99 Em estado sincrônico, 'e’tyx japake xỳ jaren' é tomado como uma única construção, com sentido de
} 'discursar'. Literalmente, seria: 'fazer um discurso para dizer'. 


\section{Aspecto e modalidade}

$O$ aspecto se refere "à tradução estritamente gramatical do tempo inerente ao evento" (CORÔA, 2005, p. 13). Logo, esse é o seu domínio, o do evento, o modo de ser da ação. Ilari (2013) diz que o aspecto tende a responder o "quanto". Quanto dura cada evento? E, mesmo: quantas vezes dura cada evento?

A modalidade, ao contrário, não pode ser restrita a uma questão ou domínio, pois gerencia a interação como um todo, observando a construção das identidades em jogo no discurso.

Dentre as três categorias de análise, a modalidade é a que mais demanda conhecimentos sociocognitivos, como ToM, pois o falante só será bem sucedido, se ele conseguir prever o modo mais adequado para se posicionar, e a isso se denomina "julgamento epistêmico".

Então, se o aspecto diz respeito ao julgamento da duração de um evento, a modalidade coloca em cena a capacidade de julgar elementos como o contexto conversacional, as identidades em diálogo e os conteúdos proposicionais. Por conta disso, diz-se que a modalidade representa a semiose da face, pois ao mesmo tempo que o falante busca preservá-la, ele precisa avançar na comunicação, conforme Miranda (2005, p. 182) explica: "Face e modalidade são como lados distintos da mesma moeda; emergem do meio da chama constitutiva da cognição humana e da linguagem."

Assim, discutiremos abaixo sobre o aspecto e, adiante, modalidade, em Pykobjê-Gavião.

\subsection{Aspecto}

Como indicado no quadro 10 , Comrie $(1976,1985)$ propõe a divisão do aspecto em perfectivo e imperfectivo. A fim de explicitar a diferença, Comrie (1976, p.15) afirma que "o perfectivo traz o ponto de vista da situação como o todo, enquanto que o imperfectivo dá atenção especial à estrutura interna da situação. ${ }^{100 "}$ Ou seja, se a situação dinâmica for vista como um evento completo, o uso estará

\footnotetext{
${ }^{100}$ Texto original: "[...] perfective indicates the view of a situation as a single whole, without distinction of the various separate phases that make up that situation; while the imperfective pays essential attention to the internal structure of the situation."
} 
relacionado ao aspecto perfectivo. Por outro lado, se a situação dinâmica for enxergada em partes de eventos, ou que se repetem invariavelmente (habitual) ou que caminham de forma progressiva (contínuo progressivo) ou não progressiva (contínuo não progressivo), será entendido como aspecto imperfectivo.

\subsubsection{Perfectivo}

Atestamos usos para perfectivo apenas em tempo não passado, ou seja, futuro ou presente, similar ao observado em línguas eslavas. Segundo Comrie (1976, p. 86), isso denota que a distinção básica de tempo, que opera em PykobjêGavião, seja não de um perfectivo presente (proposta de SILVA, 2012), mas antes daquilo que o autor denomina como "perfectivo do presente-futuro". Ou seja, a língua não precisa distinguir se o perfectivo se refere ao tempo absoluto presente ou ao tempo absoluto futuro, por isso não atestamos quaisquer usos de modal irrealis, $\{$ ha\}, em caso de perfectivo aspectualmente marcado.

Abaixo, indicaremos os dois usos observados: ry'hy e cormy

- O operador ry'hy relata o evento sob a perspectiva de uma situação como o todo. Requer um afixo com função deôntica, no caso \{'re\}, que será posposto ao verbo sobre o qual tem escopo. Desse modo, confere semântica de urgência na completude do evento, como mostra o exemplo:

\footnotetext{
28. cë ry'hy cwyr cor - 're

3PI PERF mandioca comer-DEO

'Ela já comeu a mandioca'

Literalmente: 'Ela precisa comer a mandioca'
}

Assim, seu uso seria muito similar ao ever, do Inglês Americano, conforme a expressão de largo uso: "Should you ever..." (Você já [relativa]?) ${ }^{101}$. Pois, em ambos os casos, o deôntico não é interpretado, em estado sincrônico, como elemento normativo. Tampouco, a sentença toma forma de obrigatoriedade.

\footnotetext{
${ }^{101}$ Um exemplo seria: “Should you ever text a guy first?”- Você já escreveu antes para um garoto.
} 
- Já o operador cormy, parece remeter tanto a aspecto perfectivo quanto imperfectivo contínuo progressivo, a sofrer desambiguação no contexto de uso. Com sentido perfectivo, seu uso tende a ser bastante similar ao just, do Inglês Americano:

29. Inglês:

I just meet her

'Acabei de conhecê-la'

Os dois usos possíveis seriam:

30. wa cormy te cöte wyr

1PI ASC ir riacho DIR

Interpretação 1-) 'Eu estou indo ao riacho'.

Contexto possível: Caminhando rumo ao riacho, ainda na estrada.

31. tẽm ca cormy te cöte wyr?

INT 2PI ASC ir riacho DIR

'Você já foi ao riacho?'

32. wa cormy te cöte wyr

$1 \mathrm{PI}$ ASC ir riacho DIR

'Acabei de ir ao riacho'

Interpretação 2-) 'Acabei de ir ao riacho'.

Contexto possível: O falante chegou há pouco tempo do riacho em questão.

\subsubsection{Pontual, durativo e imperfectivo}

Comrie (1976) problematiza uma dicotomia essencial, ao se analisar aspectualidade, a diferença entre estado e não estado ou dinâmica. Para Comrie, (1976, p. 49), o que muda de uma a outra instância seria haver ou não aplicação de esforço, porque "para permanecer em estado não se requer esforço algum, enquanto que permanecer em uma situação dinâmica exige esforço, seja de dentro (...) ou de fora $(\ldots)^{102}$." Se o esforço se dá de fora, trata-se de aspecto perfectivo, e

\footnotetext{
${ }^{102}$ Texto original: "To remain in a state requires no effort, whereas to remain in a dynamic situation does require effort, whether from inside $[\ldots]$ or from outside [...]."
} 
se o esforço se dá de dentro, imperfectivo. E, por sua vez, a quantidade e a qualidade desses esforços podem ser distinguidos, na imperfectividade.

A começar, Comrie (1976, p. 41, 42) diferencia imperfectividade de duratividade. Para ele, "imperfectividade significa a visualização de uma situação, que diz respeito à sua estrutura interna ${ }^{103 ", ~ e n q u a n t o ~ q u e ~ " d u r a t i v i d a d e ~}$ simplesmente se refere ao fato de que dada situação se arrasta por certo período de tempo ${ }^{104 "}$ e, por fim, a pontualidade nada mais seria do que o oposto da duratividade e "significa a qualidade de uma situação que não se arrasta no tempo ${ }^{105}$ ". Ou seja, uma situação pontual ou durativa não dispõe de estrutura interna.

As situações durativas, além disso, podem se encaminhar para um ponto final natural (set terminal point), o que dará a ela uma configuração [+télico]. Ou, então, uma vez que a natureza dos eventos não determine um ponto final, essas durativas serão do tipo [-télico] ou atélicas. ${ }^{106}$

Extrapolando um pouco a discussão, da mesma forma que podemos estabelecer um paralelo entre contável/massivo no nível nominal (BACH, 1968), poderíamos refletir sobre esses mesmos fenômenos no nível verbal, o que já fora amplamente proposto em variadas correntes de estudos, sobretudo no que diz respeito à relação perfectivo/imperfectivo (CUSIC, 1981).

Em perfectivo, como o evento é visto como o todo, ele corresponderia, no nominal, ao massivo. Já em imperfectivo, devido ao fato de a atenção estar nas partes que compõem a dinâmica, no domínio nominal, corresponderia à noção de contável.

Cusic (1981) ressalta a importância de tomarmos esse exercício, ao nos depararmos com línguas apartadas da tradição gramatical formatada. Em suas palavras:

\footnotetext{
${ }^{103}$ Texto original: "[...] imperfectivity means viewing a situation with regard to its internal structure [...]."

104 Texto original: "[...] durativity simply refers to the fact that the given situation lasts for a certain period of time [...]."

${ }^{105}$ Texto original: "[...] means the quality of a situation that does not last in time [...]."

106 Para entender melhor cada um dos casos, retomamos exemplos trazidos por Wachowichs; Foltran (2006, p. 217): "Eventualidades [+télicas] se encaminham em direção a um ponto final, cujas propriedades são determinadas pela descrição do evento. Assim, na descrição de saber matemática, amar ou nadar e correr não há nenhuma especificação sobre um determinado ponto que pudéssemos afirmar que só a partir deste ponto a eventualidade se realiza como tal, sendo, por isso, caracterizadas como eventualidades atélicas. Já em pintar o quadro, comer duas maçãs, perder a caneta, ganhar o jogo, é necessário chegar ao ponto de culminação para que essas eventualidades sejam verdadeiras."
} 
Quando a investigação está limitada a línguas Indo-Europeias, a pluralidade parece ser uma propriedade de sintagmas nominais, que mais remotamente está conectada com a referência de tempo e aspecto. Mas uma investigação que inclua um conjunto menos restrito de línguas leva a uma conclusão bastante diferente: há línguas nas quais a pluralidade é claramente uma categoria de verbos, não de nomes, e nestas línguas pluralidade e aspecto são inseparáveis. ${ }^{107}$ (CUSIC, p. 01, 02, tradução nossa)

No domínio nominal do Pykobjê-Gavião, o plural do sintagma nominal tende a ser marcado para indicar leitura plural coletiva, tomando como relevantes para a distinção lexical os traços [ thumano].

No que diz respeito às formas de pluralidade do nível nominal, o plural e as leituras de coletivo tendem a ser marcados por meio de morfemas lexicais dispostos à periferia direita do nome. Quando a referência é coletiva, ela é indicada por meio do uso de catëë jë. Este item lexical é formado a partir da justaposição de duas palavras: catëë, que significa 'ajuntamento' e jë, que remete à ideia de parentesco nessa língua (apropriado, inclusive, como um termo de classe), também sendo o sufixo que denomina o povo Jê.

Catëë jë forma uma única palavra lexical, com o sentido de 'o grupo de pessoas, de coisas', à revelia de o nome em questão ser [ \pm animado], e deve estar sempre disposto à direita do substantivo que modifica, como ocorre com relação ao nome do povo em questão, Pycop catëë jë. Então, o uso é de catëë jë e não apenas jë (discutido adiante) porque o domínio da deusa Pycop, segundo a mitologia, estender-se-ia não só às pessoas, mas também ao domínio animal e vegetal por onde este povo nômade, em seus primórdios, teria passado. Dispomos mais exemplos abaixo:

33. a'craare catëë jë j-acry

criança COL PR-estar.alegre/alegre

'A criançada está alegre'

34. nee ẽjcre catëë jë tõm noore

NEG casa COL estar.sujo/sujo NEG

'As casas (todas da aldeia) não estão sujas'

\footnotetext{
${ }^{107}$ Texto original: "When investigation is limited to Indo-European languages, plurality appears to be a property of noun phrases which is at beast remotely connected with time reference and aspect. But an investigation which includes a less restricted set of languages leads to a quite different conclusion: there are languages in which plurality is clearly a category of verbs, not of nouns, and in such languages plurality and aspect are inseparable."
} 
Observemos que acima tanto em (33) quanto em (34), catëë jë expressa um conjunto de seres ou coisas da mesma espécie, que engloba tanto os átomos quanto suas somas. Isto quer dizer que acraare catëë jë pode significar, por exemplo:

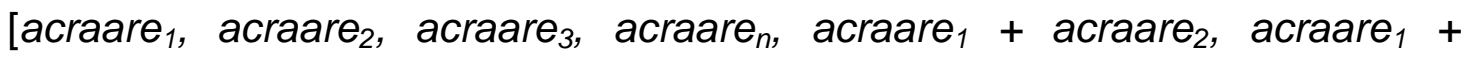
acraare $_{3}$, acraare $_{1}+$ acraare $_{n}$, acraare $_{2}+$ acraare $_{3}$, acraare $_{2}+$ acraare $_{n}$, acraare $_{3}+$ acraare $_{n}$, acraare $_{1}+$ acraare $_{2}+$ acraare $_{3}+$ acraare $\left._{n}\right]$

E ejcrẽ catëë jë poderia ter o seguinte domínio:

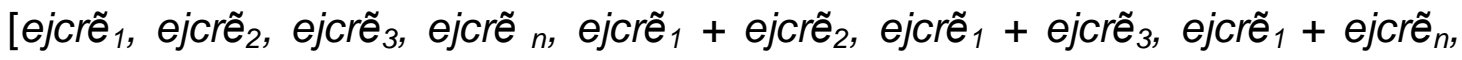

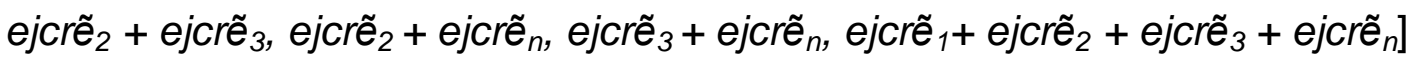

Ainda com a referência de coletivo, a palavra jë, assim como a marca de plural, me (vista logo adiante), une-se apenas aos nomes [+humano], como podemos notar a partir dos exemplos dados abaixo. Observemos, também, que em (37), jë, ao modificar o nome cate, que é homófono ao advérbio de intensidade com sentido de "muito"108, gera um vocábulo lexicalmente inusitado (muito + coletivo de gente $=$ multidão), que mantém a semântica [+humana]:

35. mentow jë j-acry

rapaz COL PR-estar.alegre/alegre

'A rapaziada está alegre'

36. encët jë j-acry

velho COL PR-estar.alegre/alegre

'Os antepassados estão alegres'

37. cate jë j-acry

muito COL PR-estar.alegre/alegre

'A multidão está alegre'

${ }^{108}$ Um exemplo em que aparece 'cate' em sua função adverbial segue:

Xoo-mỹ xow caacaa cate

cão-DAT sentir quente muitoADV

'O cão está com muito calor' 
Os nomes podem receber marca de plural, através do morfema independente \{me\}. Assim como Amado (2004) já havia observado, essa partícula nominal está restrita semanticamente aos nomes que carregam o traço [+humano], conforme fica mais perceptível a partir do teste disposto abaixo:

38. $\mathbf{m e} \tilde{e}^{109}$ hõm caprëë - re

$\mathrm{PL}$ pai estar.triste/triste-DIM

'Os pais estão tristonhos'

39. me copry caprëë - re

$\mathrm{PL}$ menina estar.triste/triste-DIM

'As meninas estão tristonhas'

40. ?me rop caprëë - re

$\mathrm{PL}$ onça estar.triste/triste-DIM

'As onças estão tristonhas'

Sobre a partícula de plural [+humano], corroboramos da hipótese proposta por Amado (2004) de que, na verdade, essa marca de plural tenha sido recuperada diacronicamente da classe dos pronomes. Essa parece ser uma explicação possível para a restrição semântica observada, uma vez que os pronomes têm uma referência [+humana] mais forte do que aquela verificada nos nomes prototípicos.

Já no nível verbal, esse tipo de pluralidade tende a ser marcado, principalmente, de três formas: pela reduplicação, restrita a algumas raízes verbais; por meio de advérbios temporais de cardinalidade; ou através de advérbios de frequência, que apresentam uma cardinalidade mais vaga, em que os eventos podem estar preenchendo plenamente o intervalo determinado ou apenas marcando-o pontualmente ${ }^{110}$. Apesar de as posições variarem relativamente, parece que advérbios de cardinalidade tendem a ocupar preferencialmente a posição pós-

\footnotetext{
${ }^{109}$ Acreditamos que esses exemplos em que a partícula $\{$ me $\}$ aparece levemente anasalada seja um caso de nasalização regressiva, isto é, a nasal da vogal do nome é assimilada pela partícula $\{$ me $\}$, indicativa de plural. Esse traço fonológico parece ser mais forte na fala dos mais velhos.

${ }_{110}$ Para ter uma visão ampliada sobre como um evento pode se distribuir em tempo, espaço ou participante, sugerimos a leitura de CABREDO HOFHERR, P. Verbal plurality and event plurality. Leipzig Sommerschule Typologie, 2010. Disponível em: http://www.eva.mpg.de/lingua/conference/2010_summerschool/pdf/course_materials/Cabredo2010plV.pdf. Acesso: 10/07/2016.
} 
verbal, ao passo que os de frequência variam entre início de sentença e posição pós-S. Assim, buscaremos, a seguir, comentar cada uma das estratégias citadas.

Cusic (1981) distingue dois tipos de pluralidade verbal, a ação com leitura repetitiva, em que, segundo o autor, o predicado está fixado lexicalmente; e a ação com leitura repetida em que o predicado remonta a cada um dos eventos ou situações descritos pelo verbo. Tomando exemplos válidos em Português, para ilustrar a proposta de análise, teríamos como leitura repetitiva (41) e repetida (42):

41. Júlia mordisca queijo. ${ }^{111}$

42. Ana come queijo duas vezes por semana..$^{12}$

Voltando ao estudo sobre o Pykobjê-Gavião, vemos que certas raízes verbais podem sofrer duplicação, de modo a proporcionar uma leitura repetitiva, similar às relações dispostas entre pares verbais do Português, tais como saltar-saltitar e morder-mordiscar, este último visto em (54). Dispomos, abaixo, um exemplo em Pykobjê-Gavião:

43. awca'te ẽ'-pỹm

FUT/LEX 3PD-cair

'Amanhã ele cairá'

44. awca'te ẽ'- pỹ̃̃pỹm

FUT/LEX 3PD-cair

'Amanhã ele cairá'

\footnotetext{
${ }^{111}$ Lasersohn (1995, p. 257) desenvolve sua análise formalista, a partir de Cusic (1981). Então, para tais predicados com sentido repetitivo, propõe a seguinte leitura: $\exists$ e [morder queijo (e) \& agente (e) = Júlia] \& $\forall e^{\prime}$, e" > e \& morder queijo (e') \& morder queijo (e') \& atômico (e') \& atômico (e") \& $|\mathrm{e}| \geq 2$

Leitura: Existe um evento, e, que é morder queijo, e o agente de e é Ana. Quaisquer que sejam os subeventos, e' e e", eles serão atômicos e estarão contidos em e. E, a cardinalidade de e deve ser maior ou igual a dois.

${ }^{112}$ Novamente apresentando a análise formal para um predicado de tal natureza, teríamos:

$\exists$ e [comer queijo (e) \& agente (e) = Ana] \& $\forall e^{\prime}$, e' $>$ e \& comer queijo (e') \& comer queijo (e'") \& atômico (e') \& atômico (e") \& $|\mathrm{e}|=2 \& \neg \mathrm{T}\left(\mathrm{e}^{\prime}\right)^{\circ} \mathrm{T}$ (e")

Leitura: Existe um evento, e, que é comer queijo, e o agente de e é Ana. Quaisquer que sejam os subeventos, e' e e", eles serão atômicos e estarão contidos em e. E, a cardinalidade de e deve ser igual a dois, o que corresponde a duas vezes por semana. E o tempo de e' não pode coincidir (overlap) com o tempo de e', o que mostra uma distributividade em tempo.
} 
No caso descrito acima, acreditamos que ocorreu uma duplicação da raiz, a qual parece conferir o sentido de repetição do evento, inerente à raiz verbal. Pỹm é um verbo intransitivo estado, que significa cair uma única vez, uma queda, ao passo que pỹỹpỹm parece indicar que o sujeito da ação cai repetidas vezes, sendo o número de quedas, igual ou maior do que dois. ${ }^{113}$

Fenômeno similar pode se dar com alguns outros verbos, inclusive transitivos, mas parece que, sendo eles transitivos, haverá redução de valência, isto é, o verbo em questão passará de transitivo para intransitivo, como veremos a seguir, em relação ao verbo "comer".

No exemplo de comer, que é um verbo transitivo simples, parece que o evento de comer é mesurado por alguma unidade relativa ao número de alimentos devorados, ou seja, cada alimento ingerido significaria um evento de comer, por isso, "fazer uma refeição/almoçar/jantar" seria um evento repetitivo, em que o número de vezes de comer precisaria ser igual ou maior do que dois ${ }^{114}$ :

45. co ha me awca'te ny a'cryt co

1EPI IRR PL FUT/LEX PT caju comer

'Nós comeremos caju amanhã'

46. *co ha me awca'te ny co

1EPI IRR PL FUT/LEX PT comer

'Nós comeremos amanhã'

47. co ha me awca'te ny coco

1EPI IRR PL FUT/LEX PT comer

'Nós jantaremos amanhã'

48. *co ha me awca'te ny a'cryt coco?

1EPI IRR PL FUT/LEX PT caju comer

'Nós jantaremos caju amanhã'

\footnotetext{
${ }^{113} \mathrm{Em}$ termos teóricos, poderíamos encontrar a seguinte formulação: [[ру̃̃̃]] $=\exists$ e [pỹm (e) \& agente (e) = ẽ'/3PD] \& $\forall e^{\prime}$, e" > e \& pỹm (e') \& pỹm (e"') \& atômico (e') \& atômico (e") \& IeI $\geq 2 \& \neg$ T (e') ${ }^{\circ} \mathrm{T}\left(\mathrm{e}^{\prime \prime}\right) \rightarrow$ distributividade em tempo

${ }^{114}$ De acordo com a discussão em voga, poderíamos sugerir a seguinte formulação de pluralidade por meio da duplicação desta raiz verbal: [[co]] $=\exists$ e [co (e) \& agente (e) = co me/1EPI PL] \& $\forall$ e', e'" > e \& co (e') \& co (e") \& atômico (e') \& atômico (e") \& |e $\mid \geq 2 \& \neg \theta$ (e') ${ }^{\circ} \theta$ (e") $\rightarrow$ distributividade entre participantes
} 
Além disso, a repetição por duplicação tende a se manifestar em verbos que parecem indicar sons onomatopaicos, como: cretcret (para dizer que a fogueira está acesa, produzindo cinzas), rõorõo (motor funcionando), crỹmcrỹm (pessoa comendo algo crocante), tactac (bater em alguma madeira repetidamente), toctoc (som da batida do relógio) e pocpoc (bater palmas).

Por vezes, alguns nomes também podem sofrer duplicação morfêmica para indicar o som que o animal produz:

49. cup cangỹgỹ ${ }^{115}$

mosca zumbir

'A mosca está zumbindo'

Van Geenhoven (2005) tratou de apresentar exemplos do groenlandês do oeste, uma língua Esquimó, em que as diversas formas de marcação da pluralidade verbal eram dispostas a partir de itens lexicais independentes e/ou morfemas com função adverbial. No Pykobjê-Gavião, também parecem ser estas, algumas estratégias comuns de que se pode lançar mão para oferecer a leitura de ação repetida.

Em (50), observamos que o quantificador funcional pode servir para indicar o número de eventos. No caso de "dormir", ngõr pexet será usado sempre que o falante quiser indicar que seu sono foi ininterrupto:

50. e'no'ny wa ngõr pexet

PAS/LEX 1PI dormir umQDC

'Ontem dormi ininterruptamente'

Literalmente: 'Ontem eu dormi uma vez' ou 'Ontem eu dormi de uma vez só'

\footnotetext{
115 Observemos que, em estado sincrônico, cangỹ denomina 'cobra', porém cangỹgỹ não remete apenas ao som da cobra se escondendo na mata, mas também ao zumbido de moscas ou mutucas (moscas grandes) e, mesmo, de seres humanos, em uso muito similar ao nosso: 'Não consigo me concentrar com todo esse zumbido ao meu lado.' Nossa hipótese é que tenha ocorrido uma generalização de cangỹgỹ, a partir do vocábulo referencial cangỹ, tomando o fenômeno da generalização, conforme proposto a partir do experimento de Watson e o pequeno Albert (MOREIRA; MEDEIROS, 2007, p. 33). Nesse caso, o psicólogo behaviorista, Watson, ensinou, via emparelhamento entre "rato" (estímulo não aversivo) e "som estridente" (estímulo aversivo), a criança Albert, a sentir medo de ratos. Mais adiante, percebeu um fenômeno ainda mais interessante, isto é, de que o menino generalizou esse medo. Albert passou a apresentar medo não só de ratos, mas também de coelhos brancos, pelúcias e, até mesmo, do Papai Noel, por ter barba branca. À observação de que estímulos condicionados podem passar a eliciar respostas condicionadas, denominamos "generalização respondente".
} 
O mesmo numeral, pexet, pode se unir à posposição cỹm, formando um constructo capaz de operar distribuição (operador $\mathrm{D}$, segundo a notação proposta por Cable $(2012)^{116}$ ), de maneira similar ao que ocorre em Português com o "cada um(a)". Na sentença dada abaixo, vemos que o uso de pexet cỹm opera uma distribuição por participante, ou seja, ocorre um evento para cada um dos participantes dispostos e, por essa razão, o sujeito terá, necessariamente, referência plural, conforme o exemplo dado abaixo ${ }^{117}$ :

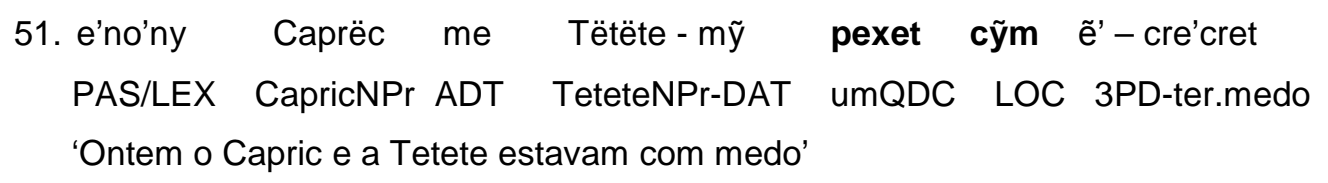

O mesmo uso observado com pexet pode ser realizado com o numeral que indica 'dois' ou 'três', em Pykobjê-Gavião, de modo que poderíamos depreender uma estrutura do tipo, "numeral cardinal + cỹm" atuando como um operador de distribuição equivalente à cardinalidade do numeral. Contudo, esta variante linguística dispõe, na sincronia, de apenas três itens lexicais próprios, sendo os demais numerais cardinais (o mesmo observado no que se refere aos numerais ordinais) emprestados do Português. Portanto, seria relevante observar em estudos futuros como os falantes marcariam, por exemplo, "de quatro em quatro", "de cinco em cinco", e assim sucessivamente, a fim de entender se a estrutura proposta acima manter-se-ia, apesar do empréstimo lexical. Por ora, seguem abaixo dois exemplos com axcryt, que, por sua vez, dispõem da mesma percepção lógica apresentada para pexet:

52. e'no'ny wa ngõr axcryt PAS/LEX 1PI dormir doisQDC

'Ontem dormi duas vezes'

(Havendo, necessariamente, um intervalo de tempo entre uma dormida e outra)

\footnotetext{
${ }^{116}$ Para entender melhor as propostas formais sobre a semântica de plurais, de Seth Cable (2012), sugerimos a leitura de seus resumos programáticos, parte deles disponível no seguinte endereço: http://people.umass.edu/scable/LING753-SP12/Handouts/1.Background-Plurality.pdf Acesso: 11/07/2016.

${ }^{117}$ Seguindo a notação proposta por Cable (2012), a LF (logical form) da sentença (64) seria: [[Caprëc me Tëtëte] [D[cre'cret]]], de modo que teríamos a seguinte leitura: $\{[\mathrm{e} 1$, Caprëc], [e2, Tëtëte]\}, ou seja, tanto Caprëc quanto Tëtëte partilham do medo.
} 
53. e'no'ny mẽ hõm axcryt cỹm ngõr

PAS/LEX PL pai doisQDC LOC dormir

'Ontem os pais foram dormir aos pares'

Literalmente: 'Ontem os pais dormiram de dois em dois'

Van Geenhoven (2005) observou, ainda, que há uma importante diferença entre advérbios temporais de cardinalidade, como os que foram discutimos acima, e advérbios de frequência, uma vez que estes apresentariam sempre um número bastante vago de subeventos, ao passo em que aqueles apresentariam uma cardinalidade minimamente delimitável.

Pensando em questões similares, que tangem os adjuntos do Português, que podem indicar a reiteração, Ilari (2013) discute:

\begin{abstract}
Pode-se perguntar quantas vezes uma ação se repete, e assim distinguir sentenças cujo predicado deve ser tomado em sentido "semelfactivo" (lat. semel = uma só vez) e sentenças cujo predicado expressa autenticamente a repetição. Na realidade, os meios que a língua coloca à disposição dos falantes para tratar de repetição são bastante articulados: a pluralidade pode ser caracterizada em termos numéricos ("três vezes") ou em termos indefinidos ("muitas vezes"); [...] Pode-se indicar o tipo de distribuição (regular, aleatória) dos eventos ao longo do tempo-suporte; a repetição pode ser ou não medida em períodos ("periodicamente"), pode ser ou não confrontada com uma métrica independentemente estabelecida ("diariamente", "mensalmente", "a cada união da Diretoria"), etc. (ILARI, 2013, p. 57)
\end{abstract}

Além disso, como já dissemos acima, em Pykobjê-Gavião, parece haver alguns itens lexicais capazes de marcar o aspecto imperfectivo habitual. A marca de habitual, ry'my', por exemplo, costuma se manifestar em início de sentença e é usada para indicar, também, que o momento da referência coincide com o momento da fala (tempo presente), conforme previsto por Comrie (1976, p. 39).

Nos termos apresentados por van Geenhoven (2005), seria algo próximo daquilo que a autora descreveu como operador estrela/asterisco flor $\left({ }^{*} \mathrm{P}\right)$, que indica que o número de subeventos repetidos no intervalo de $\mathrm{x}$ a $\mathrm{y}$ tende a ser alto. Apresentamos abaixo o uso de ry'my', levando em consideração cada um dos tipos verbais distinguidos para o Pykobjê-Gavião, em Silva (2012).

Faremos, então, uma breve exposição dos tipos verbais que Silva (2012) distingue para o Pykobjê-Gavião. 
A autora começa afirmando que este dialeto Timbira apresenta predicados do tipo verbo-adjetivais (VA) (DIK, 1997, p. 195) e que estes podem ser separados em dois grandes módulos, a depender do número de argumentos dos quais dispõem: verbos intransitivos e verbos transitivos.

Os verbos intransitivos, por sua vez, distinguem-se em simples e estendidos. Os verbos intransitivos simples seriam de três tipos: verbo intransitivo ativo, em que o único argumento tem função semântica de agente (Sa); verbo intransitivo estado, em que o único argumento tem função semântica de paciente ou zero (So); e, verbo intransitivo processo, em que o argumento teria a função semântica de processado/transformado (Sio).

O verbo intransitivo estendido pressupõe a existência de um constituinte oblíquo, mas a função semântica do argumento parece ser apenas permitida se este for agente.

Os verbos transitivos também se distinguem em simples e estendidos, com algumas peculiaridades observadas no uso de certos operadores.

Aplicando essa discussão ao uso de ry'my', teríamos:

54. ry'my' ẽjcre enta xët

DUR casa DEM queimarINTR

'Essa/esta casa está queimando'

55. ry'my' cë te amne

DUR 3PI ir/vir para cá/lá

'Ele está indo para lá'

56. ry'my' cë cö ẽ'-pẽn

DUR 3PI água 3PD-beber

'Ele está bebendo água'

57. ry'my' ca co-mỹ cö jõor

DUR 2PI 3PD-DAT água dar

'Você está dando água para ele'

O termo lexical cahör também marca aspecto imperfectivo habitual, segundo Comrie (1976), ou operador estrela/asterisco flor $\left({ }^{\star} P\right)$, nos termos de van Geenhoven (2005). Porém, apresenta escopo reduzido para a classe semântica dos 
verbos de sucção (chupar, sugar, comer, beber, etc.), como vemos no exemplo que segue:

58. jõm craa-re cahör pryyte' cy mak

QE criança-DIM HAB gado leite sugar

'O ser criança está sugando o leite de vaca'

Por fim, a autora oferece uma análise para pensarmos uma das interpretações, que cormy pode ter, ou seja, de aspecto imperfectivo contínuo progressivo, segundo a notação de Comrie (1976, p. 25). E isso, teoricamente, refere-se ao que Van Geenhoven (2005) classificou como operador estrela/asterisco branca $\left({ }^{\star} \mathrm{P}\right)$. Ele pressupõe uma pluralidade de eventos, que declara, explicitamente, não haver qualquer hiato entre o tempo de $e_{1}$ e o tempo de $e_{n}$. Ou seja, há um esforço continuado e progressivo para que o evento se mantenha dinâmico.

Retomando o exemplo já disposto de (43) a (45), o operador estrela/asterisco branca $\left({ }^{\star} P\right)$ corresponderia à interpretação 1 , conforme segue:

\footnotetext{
59. wa cormy te cöte wyr

1PI ASC ir riacho DIR

Interpretação 1) 'Eu estou indo ao riacho'.

Interpretação 2) 'Acabei de ir ao riacho'.
}

Assim, concluímos a discussão sobre marcação aspectual em PykobjêGavião. E, para fins de comparação, apresentamos abaixo a tabela com aspectos propostos para o Apaniekrá-Canela por Alves (2003). 
Quadro 13 - Categorias de aspecto expressas por meio de auxiliares e outros operadores em Canela (Alves 2009, p.11)

\begin{tabular}{|c|c|c|}
\hline \multicolumn{3}{|c|}{$\begin{array}{l}\text { ASPECTOS IMPERFECTIVOS } \\
\text { PERFECTIVOS }\end{array}$} \\
\hline Progressivo & Iterativo & Terminativo \\
\hline apu & $\overrightarrow{p t \int e t}$ & $(t o=h-\sim j-) a m r \varepsilon$ \\
\hline$t \jmath=m \tilde{s}$ & $a j-\sim p j-a k^{h} r u t$ & $($ to $=h-\sim j-)$ ipej \\
\hline$t o=t \tilde{\mathcal{E}}$ & $\eta k r \varepsilon$ & $(t o=h-\sim j-) i k u$ \\
\hline & $\left(t o=h-\sim j^{-}\right) 3$ 3tt & \\
\hline Continuativo & Ingressivo & Completivo \\
\hline$\eta p k r \varepsilon$ & $k h \tilde{a m}=t o=t \tilde{\varepsilon}$ & $\begin{array}{c}\operatorname{par}(t u) \\
i \text { P-k }^{h} r \tilde{a} k u r a\end{array}$ \\
\hline
\end{tabular}

Passamos, a seguir, para a discussão sobre modalidade, considerando o Pykobjê-Gavião e retomando que tanto Parkatêjê-Gavião quanto Canela apresentam uma marca de modo irrealis.

\subsection{Modalidade}

Conforme já discutimos, brevemente, nos tópicos anteriores, a modalidade gerencia a interação por meio de construção e reconhecimento da identidade (de si e do outro, através de ToM), além da avaliação do contexto. Nesse movimento, há um engajamento para a configuração de agentes intencionais e agentes mentais (TOMASELLO, 1999), por isso podemos dizer, grosso modo, que: o tempo versa sobre um estado temporal, o aspecto sobre o contorno da ação temporal, enquanto que a modalidade se preocupa com o tipo de realidade.

Givón (1995) discute que para fazer uso da modalidade, o falante precisa se voltar ao contexto comunicativo, para, então, elaborar um julgamento epistêmico, que o levará a:
(a) Pressuposição (verdade necessária);
(b) Asserção realis (verdade atual);
(c) Asserção irrealis (verdade possível); 
(d) Asserção negada (não verdade).

Pensando no que envolve a modalidade, Miranda (2005) explica:

Por conta disso, a modalidade representa a semiose da face, ao mesmo tempo em que se busca preservá-la, ela precisa avançar na comunicaçãoNos termos postos pelas teses sociocognitivistas, a linguagem é ação conjunta (CLARK, 1992, 1996); não há linguagem fora da interação (TOMASELLO, 1999) e a modalidade é, para nós, exatamente, a gerenciadora desse processo. O que estamos postulando, portanto, é que o núcleo definidor do fenômeno da modalidade seja o processo interacional em si. Dito em outros termos, o que o processo de modalização promove é a negociação de identidades, é a representação do drama, removendo-se barreiras ou impondo-se forças em relação ao interlocutor. (MIRANDA, 2005, p. 179-180)

Em Pykobjê-Gavião, observamos os seguintes usos:

- Quando há uma pressuposição, tende-se a recorrer à construção sintática "cë ha...", que ocupa a posição de início de frase. Vejamos dois exemplos ${ }^{118}$ :

60. cë ha to amjõ jaracwar jõwahe

3PI IRR CAUS REFL promessa cumprir

'(Tomara) Que a promessa se cumpra!'

61. cë ha wa mam ẽj-petor xy'ny aapẽn to Lucy 3PI IRR 1PI PAS/REM 1PD-fugir FIN viver CAUS NPr

'Ah, se eu tivesse fugido naquela época para casar com a Lúcia!'

- Polaridade negativa, que diz respeito à asserção negada: a afirmação se distingue da negação por meio de duas partículas (dupla negação), que podem ser aplicadas a qualquer tempo verbal: $\{$ nee... noore\}. \{noore\} deve estar posicionada sempre após o predicado, já \{nee\} pode aparecer tanto depois do sujeito (posição não marcada) quanto em início de frase, conforme vemos abaixo:

62. wa nee cö japrö noore

1PI NEG água comprar NEG

'Eu não compro água'

${ }^{118}$ Não atestamos até então construção subjuntiva aplicada ao tempo/aspecto presente. 
63. wa nee ẽj-te cö japrö noore

1PI NEG 1PD-ERG água comprar NEG

'Eu não comprei água'

64. wa ha nee cö japrö noore

1PI IRR NEG água comprar NEG

'Eu não comprarei água'

65. nee wa cö japrö noore

NEG 1PI água comprar NEG

'Eu não compro água'

66. nee (wa) ẽj-te cö japrö noore

NEG 1PI 1PD-ERG água comprar NEG

'Eu não comprei água'

67. nee wa ha cö japrö noore

NEG 1PI IRR água comprar NEG

'Eu não comprarei água'

Além de $\{$ nee... noore\}, existe uma partícula que é de uso exclusivo ao modo irrealis, \{wyyr\} (ordem canônica: tópico). Sua função já foi disposta em Amado (2004), que a considerou, então, como uma partícula portemanteau, por condensar negação e tempo futuro ${ }^{119}$. No entanto, constatamos em campo que seu uso condensado causaria enorme estranhamento, como se observa a partir dos testes dispostos abaixo:

68. wa ha cö japrö

1PI IRR água comprar

Afirmativo: 'Eu comprarei água'

69. ? wyyr wa cö japrö

NEG 1PI água comprar

'Eu não comprarei água'

70. wyyr wa ha cö japrö

${ }^{119}$ Amado (2004) considerou \{ha\} como marca de tempo futuro e não de modo irrealis, como propomos aqui. 
NEG 1PI IRR água comprar

'Eu não comprarei água'

71. wa wyyr ha cö japrö

1PI NEG IRR água comprar

'Eu não comprarei água'

Por fim, apresentamos a verdade possível.

- Partícula marca de modo irrealis (ordem canônica: $\mathrm{A}+\{\mathrm{ha}\}+\mathrm{P}+\mathrm{V}$ ) - $\mathrm{O}$ traço não marcado, nesse caso, é o modo realis. A partícula de irrealis se liga, fonologicamente (posposta), a um nome ou a um pronome independente:

72. awca'te ny cahỹj ha cwyr cor

FUT/LEX PT mulher IRR mandioca comer

'Amanhã a mulher comerá mandioca'

73. cë ha awca'te ny a'cët cỹm mor ryy'te

3PI IRR FUT/LEX PT mata LOC andarINTR muitoADV

'Amanhã ele andará muito na mata'

A marca de modo irrealis não se aplica, contudo, a todos os tipos verbais vistos na seção anterior. Pode unir-se a qualquer verbo intransitivo estendido e a todos os transitivos simples ou estendidos:

74. cë ha awca'te ny cö japrö

3PI IRR FUT/LEX PT água comprar

'Ele comprará água amanhã'

75. cë ha cahỹj pẽn jõm craa hõtyr

3PI IRR mulher PF QE criança salvar

'Ele salvará a criança da mulher'

Sentido: 'Criança será salva por ele do mal a ser infligido a ela pela mulher'

Tendo discutido sobre modalidade, considerando seu alcance sociocognitivo e possibilidades de visualização, concluímos este capítulo. 


\section{Considerações finais}

Dando sequência ao trabalho desenvolvido no Mestrado (SILVA, 2012), que tratou da distinção entre a classe dos nomes e a categoria verbal, empreendemos uma discussão sobre tempo, aspecto e modalidade (COMRIE, 1976; 1985).

Para dar conta desse objetivo, tratamos, inicialmente, sobre os pólos da Linguística, propostos em formalismos (CHOMSKY, 2008), funcionalismos (GIVÓN, 2012; NEVES, 2004) e cognitivismo (CROFT; CRUSE, 2004), e propusemos uma breve análise institucional sobre o saber-fazer dessa área, no capítulo 2. Com isso, nosso objetivo foi assinalar que a Linguística, assim como qualquer campo, é perpassada por disputas de poder, que interferem diretamente na produção dos saberes. Diante disso, discutimos o espaço reservado aos estudos em línguas subrepresentadas, como as indígenas do Brasil.

Para compreender as especificidades da comunidade de fala (HALLIDAY, 1978), no capítulo seguinte, discutimos as perspectivas identitárias (RODRIGUES, 2006), que subjaz o ethos indígena e Timbira (LADEIRA, 2012), perpassando temáticas como espaços educacionais de formação escolar, não formal e informal, a fim de tematizar o letramento (TFOUNI, 2006), a alfabetização (OLIVEIRA et al., 2001) e, com isso, fornecer mais elementos para nos aproximarmos da aquisição de Português como L2 falado e escrito (THOMASON; KAUFMAN, 1988).

No capítulo 4, consideramos os estudos que nos antecederam no que concerne às discussões sobre sociocognição e linguagem, de modo a assinalar que a linguagem é um instrumento de mediação (SOUZA, 2010), ao mesmo tempo, simbólica e gramatical, por isso não seria adequado assumir a língua afastada de sua comunidade de fala, conforme melhor tratado no capítulo anterior. Além disso, ressaltamos que a mediação simbólica pela escrita e em língua materna é um privilégio, a que os povos indígenas do Brasil ainda não têm acesso.

Então, iniciamos o tratamento acerca das questões linguísticas próprias ao Pykobjê-Gavião, apresentando um panorama dos estudos nessa língua, no capítulo 5.

Em seguida, observamos que há distinções entre tempo metalinguístico e tempo de língua (LEVINSON, 2007), e que nem toda língua precisa dispor de tempo de língua para representar o tempo metalinguístico. Neste rol, acreditamos estar o 
Pykobjê-Gavião. Pois, tomando a predição teórica de Comrie (1985), vimos que o Pykobjê-Gavião tende a indicar tempo por meio de expressões compostas lexicalmente (lexically composite expressions) ou de itens lexicais (lexical items), tanto para tempo presente (que se confunde com a marca aspectual de imperfeito habitual), quanto para passado e futuro.

No que se refere aos tempos relativos, observamos que eles tendem a se manifestar apenas em orações relativas. Então, discutimos tempo relativo puro (COMRIE, 1985, p. 62) e tempo relativo-absoluto (COMRIE, 1985, p. 65). Porém, diante dessa constatação, entendemos que é mister retomar a descrição e análise referente a sentenças relativas (tanto com antecedentes quanto sem antecedentes).

Desse modo, ao trabalhar com relativas ou sentenças encaixadas, desejamos apontar marcas referentes às relações gramaticais, de modo a lançar pistas acerca do ordenamento ergativo-absolutivo, este contraposto ao nominativo-acusativo (DIXON, 1994), pois acreditamos que por meio do estudo e reanálise da ergatividade, poderemos entender melhor os usos de tempos relativos, conforme indicado por Comrie (1976, p. 85).

No que se refere ao âmbito apectual, discutimos perfectividade e imperfectividade (COMRIE, 1976, p. 16).

Sobre perfectividade, destacamos o uso de ry'hy e cormy. Sobre imperfectividade (COMRIE, 1976; CUSIC, 1981; van GEENHOVEN, 2005), destacamos o uso em relação complementar de cahör e ry'my' e retomamos um dos contextos de uso possível para cormy.

Por fim, discutimos a relação entre cognição e uso verbal (PINKER, 2004; TERWILLIGER, 1974), retomando alguns usos verificados em redações, realizadas por indígenas Gavião e coletadas por Amado. Assumindo o bilinguismo subcoordenado (COUTO, 2009; MYERS-SCOTTON, 2002), dialogamos com os modelos teóricos propostos por Myers-Scotton (2002), para quem "os fenômenos de contato oferecem uma janela empírica sobre como a língua 'funciona'. ${ }^{120,}$

Desenvolvemos as análises, pautados por duas propostas centrais: Princípio da Estrutura Uniforme (USP) e Modelo dos 4 morfemas (4-M Model), que, por sua vez, deriva na Hipótese do Acesso Diferencial. Tomando a escala de aquisição mórfica, teríamos o seguinte nível de aquisição: morfemas de conteúdo > morfemas

\footnotetext{
${ }^{120}$ Texto original: "[...] contact phenomena offer an empirical window on how language 'works'."
} 
de aquisição precoce $>$ morfemas de aquisição tardia do tipo ponte $>$ morfemas de aquisição tardia externos.

Vimos que os verbos, apesar de terem uma raiz que se enquadraria como morfema de conteúdo, tende a ser um campo de difícil aquisição em PB, uma vez que apresenta estrutura flexional (morfemas DMT + DNP), que envolve morfemas de aquisição precoce.

Assim, concluímos a presente Tese, reconhecendo a longa estrada, que ainda precisamos trilhar nos estudos indigenistas e, também, sobre o PykobjêGavião. 


\section{Referências}

ABREU, L. C.; OLIVEIRA, M. A.; CARVALHO, T. D.; MARTINS, S. R.; GALLO, P. R.; REIS, A. O. A. A epistemologia genética de Piaget e o construtivismo. Rev. Bras. Crescimento Desenvolvimento Hum. 20(2), 2010, p. 351-360.

AKHTAR, N. Acquiring basic word order: evidence for data-driven learning of syntactic structure. In: TOMASELLO, M.; BATES, E. (eds.) Language development: the essential readings. United Kingdom: Blackwell Publishing, p. 187-202, 2001.

ALENCAR, C. N. Identidade e poder: reflexões sobre a linguística crítica. In: RAJAGOPALAN, K.; FERREIRA, D. M. M. (Orgs.) Práticas em linguagem: perspectivas identitárias. São Paulo: Editora Mackenzie, 2006, p. 39-60.

ALVES, F. C. O Timbira falado pelos Canela-Apãniekra: uma contribuição aos estudos da morfossintaxe de uma língua Jê. 2004. Tese. (Doutorado em Linguística) - Instituto de Estudos da Linguagem, Universidade Estadual de Campinas, Campinas, 2004.

Tempo, aspecto e modalidade em Canela. ReVEL. Edição Especial. N. 3, 2009, p. 01-17.

AMADO, R. S. Aspectos morfofonológicos do Gavião-Pykobjê. Tese de Doutorado em Semiótica e Linguística Geral. Faculdade de Filosofia, Letras e Ciências Humanas, Universidade de São Paulo (USP). São Paulo, 2004.

; SILVA, T. R. "Estudando em 'termos' a língua Pykobjê-Gavião".

Guavira Letras. Três Lagoas, v. 8, pp. 82-93, 2009. Acesso em:

http://www.revistaguavira.com.br/guavira8/07-artigo-talita-rosane.pdf

ANCHIETA, J. Arte de gramática da língua mais usada na costa do Brasil. São Paulo: Loyola, 1990.

ANDERSON, S. R. On the notion of subject in ergative languages. In: LI, C. N. (Ed.) Subject and topic. New York: Academic Press, 1976, p. 1-24.

Inflectional morphology. In: SHOPEN, T. (Ed.) Language typology

and syntactic description: grammatical categories and the lexicon. vol. 3. Cambridge: Press Syndicate of the University of Cambridge, 1985, p. 150-201.

ARENDT, H. Eichmann em Jerusalém: um relato sobre a banalidade do mal. Tradução: José Rubens Siqueira. São Paulo: Companhia das Letras, 1999. 
BACH, E. Nouns and Noun Phrases. In: BACH, E. HARMS, R. T. (eds.) Universals in Linguistic Theory. New York: Holt, Rinehart and Winston, p. 90-122, 1968.

BALIEIRO JR., A. P. Psicolinguística. In: MUSSALIM, F.; BENTES, A. C. (Orgs) Introdução à linguística: domínios e fronteiras. São Paulo: Cortez, 2009.

BARATA, M. H. Os Pukobie e os kupen: análise de um drama. 1981. Dissertação (Mestrado em Antropologia) - Instituto de Ciências Sociais, Universidade de Brasília, 1981.

A antropóloga entre facções políticas indigenistas: um drama do contato interétnico. Belém: Museu Paraense Emílio Goeldi, 1993.

BAREMBLITT, G. F. Apresentação do movimento institucionalista. Comunicação Oral (aula proferida no curso de Agente de Saúde Mental), 1987, p. 109-119.

BAUMAN, R. "Introduction: story, performance and event" in Story, performance and event. Contextual studies of oral narrative. Cambridge: Cambridge University Press, 1986.

BLOOM, L.; RISPOLI, M; GARTNER, B.; HAFITZ, J. Acquisition of complementation. In: TOMASELLO, M.; BATES, E. (eds.) Language development: the essential readings. United Kingdom: Blackwell Publishing, p. 248-266, 2001.

BORGES, M. F. Aspectos morfossintáticos das relações genitivas na língua Kayapó. Moara - Revista dos Cursos de Pós-Graduação em Letras. Belém: Universidade Federal do Pará, v. 4, p. 77-82, 1996.

BRUM, E. Coluna: Diálogos sobre o fim do mundo, El Pais, set./2014. Disponível em: http://brasil.elpais.com/brasil/2014/09/29/opinion/1412000283 365191.html (Acesso: 16/10/2016)

BUTLER, Judith. Problemas de gênero: feminismo e subversão da identidade. Rio de Janeiro: Civilização Brasileira, 2003.

BYBEE, J. L. Morphology: a study of the relation between meaning and form. vol. 9. Typological studies in language (TSL). Amsterdam/Philadelphia: John Benjamins Publ. Co., 1985.

CAFFAREL, A; MARTIN, J. R.; MATTHIESSEN, C. M. I. M. Introduction: systemic functional typology. In: CAFFAREL, A; MARTIN, J. R.; MATTHIESSEN, C. M. I. M. (Eds) Language typology: a functional perspective. Amsterdam/Philadelphia: John Benjamins Publishing, 2004. 
CAMARA JR, J. M. Dicionário de linguística e gramática - referente à língua portuguesa. Rio de Janeiro: Vozes, 2009.

CAIXETA, M.; CAIXETA, L. Teoria da mente: aspectos psicológicos, neurológicos, neuropsicológicos e psiquiátricos. Campinas: Editora Átomo, 2005.

CHIERCHIA, G. Semântica. Campinas: Editora da Unicamp, 2003.

CHOMSKY, N. Lectures on government and binding. Dordrecht: Foris, 1981.

Arquitetura da linguagem. Tradutores: Alexandre Morales, Rafael

Ferreira Coelho. São Paulo: Edusc, 2008.

COLLISCHONN, G. A sílaba em português. In: BISOL, L. (Org.) Introdução a estudos de fonologia do português brasileiro. Porto Alegre: EDIPUCRS, 1996. p. 95130.

COMRIE, B. Aspect: an introduction to the study of verbal aspect and related problems. United Kingdom: Cambridge University Press, 1976.

Tense. United Kingdom: Cambridge University Press, 1985.

COROA, M. L. M. S. O ensino de língua portuguesa e a construção de identidades. In: RAJAGOPALAN, K.; FERREIRA, D. M. M. (Orgs.) Práticas em linguagem: perspectivas identitárias. São Paulo: Editora Mackenzie, 2006, p. 143-166.

CORÔA, M. L. M. S. O tempo nos verbos do português. São Paulo: Parábola, 2005.

COUTO, H. H. Multilingüismo. In: Lingüística, ecologia e ecolingüística. São Paulo: Contexto, 2009.

CROFT, W. Syntatic categories and grammatical relations - The cognitve organization of information. Chicago and London: The University of Chicago Press, 1991.

CROFT, W.; CRUSE, D. A. Cognitive linguistics. New York: Cambridge University Press, 2004.

CUNHA, M. C. (Org.) História dos índios no Brasil. São Paulo: Companhia das Letras, 2008.

CUSIC, D. Verbal Plurality and Aspect. Ph.D. Dissertation, Stanford University, 1981. DeLANCEY, S. On functionalism. Lecture. Santa Barbara: LSA Summer Institute, 2001.

DeVILLIERS, J. Can language acquisition give children a point of view? In: ASTINGTON, J. W.; BAIRD, J. (Eds) Why language matters for theory of mind. New York: Oxford University Press, 2005, p. 186-219. 
DIK, C. S. The theory of functional grammar - Part 1. Berlin; New York: Mounton de Gruyter, 1997a.

The theory of functional grammar - Part 2. Berlin; New York: Mounton de Gruyter, 1997b

DOWNES, W. Language and society. 2a edição. Cambridge: Cambridge University Press, 1988.

DRYER, M. S. The greenbergian word order correlations. Language, v. 68, n. 1, p. 81-138, 1992.

Functionalism and the metalanguage - Theory Confusion, 1999.

Acesso em: linguistics.buffalo.edu/people/faculty/dryer/dryer/DryerFuncMeta.pdf $(20 / 10 / 2016)$

DUNN, J.; BROWN, J.; BEARDSALL, L. Family talk about feeling states and children's later understanding of other's emotions. Development Psychology, 27, 1991, 448-455.

DURANTI, A. (ed.) Linguistic anthropology: a reader. Malden, Mass.: Blackwell, 2001.

DURKHEIM, E. Da divisão do trabalho social. Tradutor: Eduardo Brandão. São Paulo: Martins Fontes, 1999.

ECO, U. Como se faz uma tese. São Paulo: Perspectiva, 2010.

FERREIRA, M. N. O. Estudo morfossintático da língua Parkatejê. 2003. Tese (Doutorado em Linguística) - Instituto de Estudos da Linguagem, Universidade Estadual de Campinas, Campinas, 2003.

FERREIRA, R. Ser e não ser: eis a questão - as minorias sexuais entre a legitimidade da diferença e o perigo de sua ontologização. In: RAJAGOPALAN, K.; FERREIRA, D. M. M. (Orgs.) Práticas em linguagem: perspectivas identitárias. São Paulo: Editora Mackenzie, 2006, p. 177-204.

FIGUEIREDO, L. C. M. A invenção do psicológico: quatro séculos de subjetivação, 1500-1900. São Paulo: Escuta, 2007.

FILHO, A. J. Educação escolar indígena: identidade e discursividade. In: RAJAGOPALAN, K.; FERREIRA, D. M. M. (Orgs.) Práticas em linguagem: perspectivas identitárias. São Paulo: Editora Mackenzie, 2006, p. 205-226.

FILLMORE, C. J. Topics in lexical semantics. In: COLE, P. (ed.) Current issues in linguistic theory. Bloomington: Indiana University Press, p. 76-138, 1976. 
The case for case reopened. In: COLE, P; SADOCK, J. M. (ed.) Syntax and semantics: Grammatical relations. Vol. VIII. New York: Academic Press, p. 59-81, 1977.

FONSECA, V. R. J. R. M. Do homo ergaster ao homo autisticus: aspectos filogenéticos e ontogenéticos do desenvolvimento da mente e seus desvios. In: Jornal de Psicanálise, vol. 45, n. 83, 2012, p. 191-202.

FOUCAULT, M. Em defesa da sociedade. São Paulo: Martins Fontes, 2000.

$A$ arqueologia do saber. Tradução: Luiz Felipe Baeta Neves. Rio de Janeiro: Forense Universitária, 2002.

FREIRE, P. A concepção "bancária" da educação como instrumento da opressão: seus pressupostos, sua crítica. Pedagogia do oprimido. São Paulo: Paz e Terra, 2002.

FREITAS, A. C. As identidades do Brasil: buscando as identificações ou afirmando as diferenças? In: RAJAGOPALAN, K.; FERREIRA, D. M. M. (Orgs.) Práticas em linguagem: perspectivas identitárias. São Paulo: Editora Mackenzie, 2006, p. 227254.

FREITAS, M. F. Revisitando os verbos em Parkatêjê: questões relevantes para um estudo morfossintático. 2008. Dissertação (Mestrado em Letras) - Centro de Letras e Artes, Universidade Federal do Pará, Belém, 2008.

GAZZANIGA, M. The bisected brain. New York: Appleton-Century-Crofts, 1970.

GIDDENS, A. As consequências da modernidade. São Paulo: Editora Unesp, 1991.

GIVÓN, T. Functionalism and grammar. Amsterdam/Philadelphia: John Benjamins Publishing Company, 1995.

Grammatical relations: an introduction. In: GIVÓN, T. (Ed.) Grammatical relations, a functionalist perspective. Amsterdam/Philadelphia: John Benjamins Publishing Company, 1997.

Sintax I, II (an introduction). Amsterdam/Philadelphia: John Benjamins Publishing Company, 2001.

A compreensão da gramática. Tradução: Maria Angélica Furtado Cunha, Mário Eduardo Martelotta, Filipe Albani. São Paulo: Cortez, 2012.

GOODY, J \& WATT, I. As consequências do letramento. São Paulo: Paulistana, 2006. 
GUIRADO, M. A psicologia institucional de Bleger. In: GUIRADO, M. (Org.) Psicologia institucional. São Paulo: EPU, 1987.

HALLE, M.; VERGNAUD, J. R. An essay on stress. Cambridge, Massachussets: MIT Press, 1987.

HALL, S. Identidades culturais na pós-modernidade. Rio de Janeiro: DP\&A, 2000.

HALLIDAY, M. A. K. Language as social semiotic. London: Edward Arnold, 1978.

HAYES, B. Metrical Stress Theory: Principles and Case Studies. Chicago: University of Chicago Press, 1994.

HEIM, I.; KRATZER, A. Semantics in generative grammar. Oxford e Nova York: Blackwell, 1997.

HEINE, B. Possession: cognitive sources, forces, and grammaticalization. New York: Cambridge University Press,1997.

HILSDORF, M. L. S. História da educação brasileira: leituras. São Paulo: Pioneira Thomson Learning, 2003.

HYMES, D. On communicative competence. In: PRIDE, J. B.; HOLMES, J. (Eds.) Sociolinguistics. Harmondsworth: Penguin, 1972. p. 269-293.

Models of the Interaction of Language and Social Life. In: GUMPERZ, J. J. Directions in Sociolinguistics: The Ethnography of Communication. New York/London: Holt, Rinehart and Winston, 1972, p. 35-71.

ILARI, R. A expressão do tempo em português. São Paulo: Editora Contexto, 2012. ITÔ, J. Syllable theory in prosodic phonology. 1986. Tese (Doutorado em Linguística) - University of Massachussetts, Massachussets, 1986.

JACKENDOFF, R. Language, consciouness, culture: essays on mental structure. Cambridge: MIT Press, 2009.

JAKOBSON, R. [1958] Os estudos tipológicos e sua contribuição à linguística histórico-comparativa. In: JAKOBSON, R. Os princípios de fonologia histórica. Tradução: Wilmar D’Angelis. Campinas: Editora Curt Nimuendajú: 2008.

JANDA, L. A. Cognitive Linguistics in the year 2015. Cognitive semantics, 1, 2015, p. 131-154. Disponível em:

https://www.researchgate.net/publication/273902836_Cognitive_Linguistics_in_the_Y ear_2015 (Acesso: 20/10/2016) 
JENSEN, J. T. Morphology: word structure in generative grammar. Series IV Current Issues in Linguistic Theory. Amsterdam/Philadelphia: John Benjamins Publ. Co., 1990.

JOU, G. I.; SPERB, T. M. Teoria da mente: diferentes abordagens. Psicologia: Reflexão e Crítica, vol. 12, n. 2. Porto Alegre, 1999, p. 287-306.

KENEDY, E.; MARTELOTTA, M. E. T. A visão funcionalista da linguagem no século XX. In: CUNHA, M. A. F.; OliveiRA, M. R.; MARTElOTTA, M. E. T. (Orgs.) Linguística funcional: teoria e prática. Rio de Janeiro: Faperj, 2003.

KERBRAT-ORECCHIONI, C. La enunciacion de la subjetividad en el lenguaje. 3 ed. Buenos Aires: Edicial, 1997.

KUNDERA, M. [1986] A arte do romance. São Paulo: Companhia de Bolso, 2009.

LADEIRA, M. E. De bilhetes e diários: oralidade e escrita entre os Timbira. In: FERREIRA, M. K. L; SILVA, A. L. Antropologia, História e Educação: A Questão Indígena e a Escola. São Paulo: Editora Global, 2001.

Timbira, nossas coisas e saberes: coleções de museus e produção da vida. São Paulo: CTI - Centro de Trabalho Indigenista, 2012.

LANGACKER, R. W. A linguagem e sua estrutura: alguns conceitos linguísticos fundamentais. Rio de Janeiro: Editora Vozes Ltda, 1977.

LASERSOHN, P. Pluractional markers. In: Plurality, conjunction and events. Studies in Linguistics and Philosophers, vol. 55. Dordrecht/Boston/London: Kluwer Academic Publisher, 1995.

LEE, K.; OLSON, D.; TORRANCE, N. Chinese children's understanding of false beliefs: the role of language. Journal of child language, vol. 26, 1999, p. 1-21.

LEHMANN, W. P. The great underlying ground-plans. In: LEHMANN, W. P. (Ed.) Syntactic typology: studies in the phenomenology of language. 2. ed. Austin: University of Texas Press, 1981. p. 03-56.

LEVINSON, S. C. Pragmática. São Paulo: Martins Fontes, 2007.

LOPES DA SILVA, F. A arbitrariedade que não se encontra. Letras, Editora da UFPR, Curitiba, n. 56, 2001, p. 289-300.

LOURENÇO, L. C. A. Transferência e Complexo de Édipo, na obra de Freud: notas sobre os destinos da transferência. Psicologia: reflexão e crítica, 18 (1), 2005, p. 143-149.

LYONS, J. Semantics. Vols. 1 e 2. Cambridge: Cambridge University Press, 1977. 
LUNDY-EKMAN, L. Neurociência: Fundamentos para a reabilitação. Rio de Janeiro: Elsevier, 2008.

MARCUSCHI, L. A. A construção do mobiliário do mundo e da mente: linguagem, cultura e categorização. In: MIRANDA, N. S.; NAME, M. C. Linguística e cognição. Juiz de Fora: Editora UFJF, 2005, p. 49-78.

MATTOS E SILVA, R. V. O português são dois.... Novas Fronteiras, velhos problemas. São Paulo: Parábola Editorial, 2004.

MELATTI, J. C. O messianismo Krahô. São Paulo: Herder, 1972. Ritos de uma tribo Timbira. São Paulo: Ática, 1978.

MELIÀ, B. Educação indígena e alfabetização. São Paulo: Loyola, 1979.

MENÉNDEZ, S. M. Opción, registro y contexto. El concepto de significado en la lingüística sistémico-funcional. Tópicos del seminario, n. 23, jun-2010. Disponível em: $\quad$ http://www.scielo.org.mx/scielo.php?script=sci_arttext\&pid=S166512002010000100007 (Acesso: 07/10/2016).

MIRANDA, N. S. Modalidade: o gerenciamento da interação. In: MIRANDA, N. S; NAME, M. C. (Orgs) Linguística e cognição. Juiz de Fora: Editora UFJF, 2005, p. 171-198.

MITHUN, M. "The evolution of noun incorporation". Language. Vol. 60, n 4 (pp. 84794), 1984.

MOREIRA, M. B.; MEDEIROS, C. A. Princípios Básicos de Análise do Comportamento. Porto Alegre: Artmed, 2007.

MOURA, A. H. Breves notas sobre os antecedentes históricos da análise institucional. Comunicação Oral (palestra proferida no curso de pós-graduação em saúde coletiva da Faculdade de Medicina da Unicamp). Unicamp, 1993, p. 37-48.

MYERS-SCOTTON, Carol. Contact Linguistics: Bilingual encounters and grammatical outcomes. Oxford: Oxford University Press, 2002.

NELSON, K. Young minds in social worlds: experience, meaning and memory. Cambridge: Harvard University Press, 2007.

NEVES, M. H. M. A gramática funcional. São Paulo: Martins Fontes, 2004.

NIMUENDAJU, C. The Eastern Timbira. Berkeley and Los Angeles: University of California Publications in American Archeology and Ethnology, 1946, vol. 41. 
OCHS, E.; SCHIEFFELIN, B. B. Language Acquisition and Socialization: Three Developmental Stories and Their Implications. In: DURANTI, A. (org.) Linguistic Anthropology: a reader. Oxford: Blackwell, p. 263-301, 2001. OLIVEIRA, A. M. M.; SAMPAIO, C. S.; PEREZ, C. L. V.; ZACCUR, E.; ESTEBÁN, M. T. Alfabetização dos alunos das classes populares: ainda um desafio. 5 ed. São Paulo: Cortez, 2001.

PAPROTTÉ, W. A discourse perspective on tense and aspect in Standard Modern Greek and English. In: RUDZKA-OSTYN, B. Topics in cognitive linguistics. Series IV: Current issues in linguistic theory. Amsterdam/Philadelphia: John Benjamins Publishing Company, 1988.

PATTO, M. H. S. O conceito de cotidianeidade em Agnes Heller e a pesquisa em educação. Perspectivas, São Paulo, 1993, p. 119-141. Disponível em: http://www.ip.usp.br/portal/images/stories/MH/o_conceito_de_cotidianidade.pdf (Acesso: 20/10/2016)

Raízes históricas da concepção sobre o fracasso escolar: o triunfo de uma classe e sua visão de mundo. A produção do fracasso escolar: histórias de submissão e rebeldia. São Paulo: T. A. Queiroz Editor, 1996.

PAUL, Hermann. Princípios Fundamentais da História da Língua. Lisboa: Fundação Calouste Gulbenkian, 1966.

PAYNE, T. E. Describing morphosyntax - a guide for field linguists. New York: Cambridge University Press, 1997.

PÊSSOA, L. F.; SEIDL-DE-MOURA, M. L. Input e desenvolvimento da linguagem. In: EISenberG, Z.; PARENTE, M. A. M. P. (Orgs.) Psicologia da linguagem: da construção da fala às primeiras narrativas. São Paulo: Vetor, 2010, p. 35-56.

PETTER, M. M. T. Variedades lingüísticas em contato - português angolano, português brasileiro e português moçambicano. Tese apresentada ao Departamento de Linguística para a obtenção do título de livre docente na área de Linguística Africana. Faculdade de Filosofia, Letras e Ciências Humanas, Universidade de São Paulo (USP). São Paulo, 2008.

PEZATTI, E. G. O funcionalismo em linguística In: MUSSALIM, F.; BENTES, A. C. (Orgs) Introdução à linguística: fundamentos epistemológicos. vol. 3. São Paulo: Editora Cortez, 2009, p. 165-218. 
PINKER, S. O instinto da linguagem: como a mente cria a linguagem. São Paulo: Martins Fontes, 2004.

PINTO, J. P. O corpo de uma teoria/; marcos contemporâneos sobre os atos de fala. Cadernos Pagu, 33, jul-dez de 2009, p. 117-138. Disponível em: http://www.scielo.br/pdf/cpa/n33/05.pdf (Acesso: 10/01/2017)

POPJES, J.; POPJES, J. Canela-Kraho. In: DERBYSHIRE, D. C.; PULLUM, G. K. (Eds). Handbook of Amazonian Languages. New York: Mouton de Gruyter, 1986, p. 128-199.

Povos indígenas do Brasil. São Paulo: CEDI, 1985.

RAJAGOPALAN, K. Pós-modernidade e a política de identidade. In: RAJAGOPALAN, K.; FERREIRA, D. M. M. (Orgs.) Práticas em linguagem: perspectivas identitárias. São Paulo: Editora Mackenzie, 2006, p. 61-80.

RIBEIRO, A. A. Ser e não ser?! Que questão!: linguagens. In: RAJAGOPALAN, K.; FERREIRA, D. M. M. (Orgs.) Práticas em linguagem: perspectivas identitárias. São Paulo: Editora Mackenzie, 2006, p. 81-106.

RIBEIRO, E. R. Morfologia do verbo Karajá. 1996. Dissertação (Mestrado em Semiótica e Linguística Geral) - Faculdade de Letras, Universidade Federal de Goiás, Goiânia, 1996.

Prefixos relacionais em Jê e Karajá: um estudo históricocomparativo. Campinas: I/ Encontro Macro-Jê, 2002a. (manuscrito)

O marcador de posse alienável em Kariri: um morfema Macro-Jê revisitado. LIAMES - Línguas Indígenas da América do Sul, Campinas, v. 2, p. 3148, $2002 b$.

Macro-Jê. In: BROWN, K. (Ed.) Encyclopedia of language and linguistics. 7. 2. ed. Oxford: Elsevier, 2006. p. 422-426.

RODRIGUES, A. D. Línguas Brasileiras: para o conhecimento das línguas indígenas. São Paulo: Edições Loyola, 2002.

RODRIGUES, C.; TOMITCH, L. M. B. et alii (Orgs.). Linguagem e cérebro humano: contribuições multidisciplinares. Porto Alegre: Artmed, 2004.

RODRIGUES, E. G. Repensando a consciência (e) (a) crítica: por uma redefinição da noção de fortalecimento das identidades sociais. In: RAJAGOPALAN, K.;

FERREIRA, D. M. M. (Orgs.) Práticas em linguagem: perspectivas identitárias. São Paulo: Editora Mackenzie, 2006, p. 107-142. 
SALANOVA, A. P. A análise em Mebengokre e Apinayé: o limite do vozeamento soante. 2001. Dissertação (Mestrado em Semiótica e Linguística Geral) - Instituto de Estudos da Linguagem, Universidade Estadual de Campinas, Campinas, 2001.

SÁ, R. M. Análise fonológica preliminar do Pykobyê. Dissertação de Mestrado em Semiótica e Linguística Geral. Faculdade de Filosofia, Letras e Ciências Humanas, Universidade de São Paulo (USP). São Paulo, 1999.

SANTOS, B. S. Direitos Humanos: o desafio da interculturalidade. Revista Direitos Humanos, Secretaria Especial de Direitos Humanos, Brasília, nº 2, 2009, p. 10-18. Introdução a uma ciência pós-moderna. Rio de Janeiro: Graal, 2010.

SAVIANI, D. As teorias da educação e o problema da marginalidade na América Latina. Cad. Pesq. São Paulo (42), São Paulo, Agosto 1982, p. 8-18.

SCHACHTER, P. Parts-of-speech systems. In: SHOPEN, T. (Ed.) Language Typology and Syntactic Description. vol.1. Cambridge: Cambridge University Press, 1985. p. 3-61.

Parts-of-speech systems. In: SHOPEN, T. (Ed.) Language Typology and Syntactic Description. vol.1. 2. ed. Cambridge: Cambridge University Press, 2007. p. 1-60.

SERRES, M. Filosofia mestiça. Tradução: Maria Ignez Duque Estrada. Rio de Janeiro: Nova Fronteira, 1993.

SIGNORINI, I. (Org.) Lingua(gem) e identidade. Campinas: Mercado de Letras, 1998.

SILVA, F. L. A tragédia saussuriana: por uma nova mitologia para a ciência da linguagem. In: RAJAGOPALAN, K.; FERREIRA, D. M. M. (Orgs.) Práticas em linguagem: perspectivas identitárias. São Paulo: Editora Mackenzie, 2006, p. 15-38. SILVA, T. R. Descrição e análise morfossintática do nome e do verbo em PykobjêGavião (Timbira). vol. 66. LINCOM Studies in Native American Linguistics. München: Lincom Europa Academic Publications, 2012.

SILVA, T. T. Identidade e diferença. Petrópoles: Vozes, 2000.

SKINNER, B. F. Verbal behavior. New York: Appleton-Century-Crofts, 1957.

SOUZA, A. J. Geografia linguística, dominação e liberdade: a imposição de línguas oficiais, a fala como ato político, a dominação pela linguagem. São Paulo: Editora Contexto, 1991. 
SOUZA, D. H. A percepção da fala. In: EISENBERG, Z.; PARENTE, M. A. M. P. (Orgs.) Psicologia da linguagem: da construção da fala às primeiras narrativas. São Paulo: Vetor, 2010, p. 15-34.

De onde e para onde? As interfaces entre linguagem, teoria da mente e desenvolvimento social. In: SPERB, T. M.; MALUF, M. R. (Orgs) Desenvolvimento sociocognitivo: estudos brasileiros sobre "Teoria da Mente". São Paulo: Vetor, 2008, p. 33-54.

SOUZA, J. C. Aquisição dos tempos verbais do português por falantes de línguas timbira. 2011. Dissertação (Mestrado em Filologia e Língua Portuguesa) - Faculdade de Letras, Universidade de São Paulo, São Paulo, 2011.

SOUZA, S. M. O sistema de referência pessoal da língua Krahô. 1990. Dissertação (Mestrado em Semiótica e Linguística Geral) - Faculdade de Letras, Universidade Federal de Goiás, Goiás, 1990.

A sintaxe de uma língua de verbo no final: Krahô. Tese (Doutorado em Semiótica e Linguística Geral). Faculdade de Filosofia, Letras e Ciências Humanas, Universidade de São Paulo, São Paulo, 1997.

TFOUNI, L. V. Letramento e alfabetização. 8 ed. São Paulo: Cortez, 2006.

TERWILLIGER, R. F. Psicologia da linguagem. Tradução de Leonidas Hegenberg e Octanny Silveira da Mota. São Paulo: Editora Cultrix/Editora da Universidade de São Paulo, 1974.

TOMASELLO, M. The cultural origins of human cognition. Cambridge: Harvard University Press, 1999.

THOMASON, S.; KAUFMAN, T. Language contact, creolization and genetic linguistics. Berkeley: University of California Press, 1988.

van GEENHOVEN, V. Atelicity, pluractionality and adverbial quantification. In: VERKUYL, H. J.; SWART, H.; van HOUT, A. Perspectives on Aspect. Studies in Theoretical Psycholinguistics, Vol. 32. Cambridge: University of Massachusetts, 2005.

VERAS, V. Identidade, repetição e temporalidade. In: RAJAGOPALAN, K.; FERREIRA, D. M. M. (Orgs.) Práticas em linguagem: perspectivas identitárias. São Paulo: Editora Mackenzie, 2006, p. 329-340.

VIGOTSKI, L. A construção do pensamento e da linguagem. São Paulo: Martins Fontes, 2009. 
WACHOWICZ, T. C.; FOLTRAN, M. J. Sobre a noção de aspecto. Caderno de Estudos Linguísticos de Campinas, 48(2), p. 211-232, 2006. 


\section{Apêndices}

Quadro 14 - Grafia Uniformizada Timbira (AMADO, 2004, p. 158-160)

OFICINA DE GRAFIA UNIFORMIZADA TIMBIRA

LETRAS APROVADAS EM 12.12.2003

\begin{tabular}{|c|c|}
\hline CONSOANTES & VOGAIS \\
$\mathrm{p}-\mathrm{t}-\mathrm{x}-\mathrm{c}-\mathrm{k}-$ & $\mathrm{a}-\mathrm{e}-\ddot{\mathrm{e}}-\tilde{\mathrm{e}}-\tilde{\mathrm{i}}$ \\
$\mathrm{m}-\mathrm{n}-\mathrm{g}$ & $\mathrm{y}-\mathrm{y}-\tilde{\mathrm{y}}$ \\
$\mathrm{w}-\mathrm{r}-\mathrm{j}-\mathrm{h}$ & $\mathrm{o}-\ddot{\mathrm{o}}-\tilde{\mathrm{o}}-\tilde{\mathrm{u}}$ \\
\hline
\end{tabular}

\section{EXPLICAÇÃO DAS CONSOANTES}

1. $\mathrm{c}-\mathrm{k}$

$\mathrm{c} \rightarrow[\mathrm{k}]$ - para final de sílaba: hapac 'orelha dele'

c, $\mathrm{k} \rightarrow$ respectivamente [ $\mathrm{k}$ ] e [ $\mathrm{k}^{\mathrm{h}}$ ] - para início de sílaba: ca '2p', kõc 'camaleão'

2. $\mathrm{h}-$,

$\mathrm{h} \rightarrow[\mathrm{h}]$ - para início de sílaba: hapac 'orelha dele'

' $\rightarrow$ [?] - para final de sílaba: pa'nõ - nome próprio

3. $\mathrm{g}-\mathrm{h}$

Os Krinkati escreverão $\langle\mathrm{h}\rangle$ onde os falantes das outras línguas Timbira escreverão $\langle\mathrm{g}\rangle$ (para os Pykobjê $\left.\rightarrow\left[{ }^{\mathrm{g}} \mathrm{g}\right]\right)$ : cahã / cagã 'cobra', hõr / gõr 'dormir'.

4. $\mathrm{j}-\mathrm{x}$

Os Pykobjê escreverão $\langle x>$ no final de algumas palavras enquanto os falantes das outras línguas Timbira escreverão $\langle\mathrm{j}>$ : caj / cax 'cesto'.

5. $\mathrm{p}-\mathrm{t}-\mathrm{x}-\mathrm{m}-\mathrm{n}-\mathrm{w}-\mathrm{r}$

[ $\left.\mathrm{p}, \mathrm{t}, \mathrm{t} \int, \mathrm{m}, \mathrm{n}, \mathrm{w}, \mathrm{r}\right]$ - como em todas as línguas Timbira essas letras já estavam sendo escritas da mesma forma, elas foram mantidas.

\section{EXPLICAÇÃO DAS VOGAIS}

1. $\mathrm{a}-\tilde{\mathrm{y}}$

[ a ], [ ã ] / [ ̃̃ ] (este para o Pykobjê): ca '2p', pa '1p', cahỹj 'mulher' 
2. $y-\grave{y}$

Alguns povos dizem [ 3 ] ou [ ə ], enquanto outros dizem [ ə ] ou [ i ] (Pykopjê), mas todos escreverão < ỳ >: kwỳr 'mandioca'.

Alguns povos dizem [ $\mathfrak{i}$ ], enquanto outros dizem [ ə ] (Pykobjê), mas todos escreverão $<y>$ :.

3. $\mathrm{e}-\ddot{\mathrm{e}}$

Alguns povos dizem [ $\varepsilon$ ], enquanto outros dizem [ e ] (Pykobjê), mas todos escreverão $<\mathrm{e}>$ : tep 'peixe'.

Alguns povos dizem [ e ], enquanto outros dizem [ i ], mas todos escreverão $<$ ë $>$ : caapër 'bacaba', parëj 'cajá'121.

4. $\mathrm{o}-\ddot{\mathrm{o}}$

Alguns povos dizem [ 0 ], enquanto outros dizem [ o ] (Pykobjê), mas todos escreverão < o >: rop 'onça'.

Alguns povos dizem [ o ], enquanto outros dizem [ $\mathrm{u}$ ], mas todos escreverão $<\ddot{o}>$ : caprö 'sangue', cömxë 'bacuri' ${ }^{122}$.

5. $\tilde{\mathrm{e}}-\tilde{\mathbf{1}}$

Alguns povos dizem [ $\tilde{\varepsilon}$ ], enquanto outros dizem [ ẽ ] (Pykobjê), mas todos escreverão $<\tilde{\mathrm{e}}>$ : cötẽ 'murici'.

Alguns povos dizem [ ẽ ] (Pykobjê), enquanto outros dizem [ $\tilde{1}$ ], mas todos escreverão $\langle\tilde{1}\rangle$ : mĩ 'jacaré'.

6. $\tilde{\mathrm{o}}-\tilde{\mathrm{u}}$

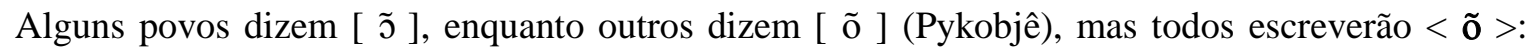
wakõ 'quati'.

Alguns povos dizem [ õ ] (Pykobjê), enquanto outros dizem [ ũ ], mas todos escreverão $<\tilde{\mathrm{u}}>$ : hũmre 'homem'.

${ }^{121}$ Para esse grafema não há previsão, em nenhuma das línguas Timbira, sobre a realização em [ e ] ou [ i ].

${ }^{122} \mathrm{O}$ mesmo, sobre a realização em [ o ] ou [ u ]. 


\title{
Redações Timbira digitadas (SOUZA, 2011, p. 76-83)
}

\author{
Os textos abaixo são cópias fieis das redações timbiras e estão desprovidos de quaisquer \\ correções ou modificações.
}

\section{Texto 1}

1.Antigamente as tradições do povo Krahô, os mais velhos contam assim: Os krahôs dos antepassados 2.viviam nús, viajavam a pé, faziam muitas festas, não tinham lugares certos para morar, não tinham limites 3.do territórios, não tinham contatos diretos com as sociedades regionais e não usavam shorts.

4.Nos dias de hoje, muitas coisas mudou. Os jovens não viajam a pé, só espera o carro, não podem andar 5.nús, usar direto o short, quase não tem festa todo dia, vai direto a cidade próximo, precisa de todo 6.documento para viajar a grande cidade, quando tem a festa na aldeia só o velho participar, e o jovem fica 7.dentro da casa curtindo música, assistindo $\mathrm{TV}$,etc. $\mathrm{E}$ assim por diante, as crianças que ainda estão 8.crescendo preceber ...

9.As crianças que estão crescendos perceber e quando vão crescer, não acompanhar e respeita a tradição, 10.somente vai desvalorizar a cultura

Texto 2

1.Os meus povos brasileiros nos passado, eram muito forte para luta a guerra, eles se pintavam para 2.convence seu inimigo.

3.As populações indígenas Timbira, tivemos característica para caçar, pescar,pintar e plantar na roça.

4.Hoje em dia para nós, sabemos que a nossa tradição é forte, porque nos preservamos muito, nós corremos 5.com tora,cantamos no pátio, caçamos na mata, pescamos no rio, lagoa,ribeirão e córrego mais próximo da 6.aldeia.

7.O meu futuro, eu não vou deixa a minha tradição, nós sabemos que quaze toda indígenas estarão perdendo 8.os costumes do seu próprio povos. Nós que vivemos no norte do Estado, estamos comprendo e preservando 9. tudo que nossos povos krahô deixar

Texto 3

1.Antigamente o índio estarão a qui para discutir aqueles coisas está no passado e nós querem faze pra ter 2.mais alegria e ter grande animação da casa, porque na minha realidade eu nim pensei pra mim fazer uma 3.única coisa que é mais verdade [...] pra mim decora no meu pensamento.

4.A aula da qui foi muito importante pelos professora Rosane e eu gostei muito da aula dela e fiquei mais 5.feliz, hoje e a aprender sobre estudo. Coisa linda coisa no presente e que dizer que a final aula vai ajutaram 6.muita gente aqui na escola.

7.Vamos pensar desse o que vai acontecer nesse animação da festa aqui na escola indígena timbira temos 8.vario discussão a gente fazer aqui queremos explicar que dia mais [...] ou periodo que vai ter grande 9. animação dos alunos.

Texto 4

1.No ano de 1989 tinha muitas festas e não cortam cabelo como hoje que os homens,cortarão mais os mais 2.velhos gostava de ir para a cidade que eles não tinha nada como nós temos um pouco.

3.Porque só ce acaba com a nossas cultura que os meus bisavós nós usar, que na minha você não ver os 4.jovens cortando os cabelos como os cupê cortam os cabelos ne as mulheres não gria os cabelos as cupê.

5.Já tem os nossos jeito de viver que antigamente não tinha nada de cupê e não. Mas agora nós que ficam na 6.aldeia nós não temos mais resguarda como os mais velhos tinha, agora nós comem as coisas que os cupê 7.comem

8.Mais agora nos estamos ensinando as crianças cantar que eles estão aprendendo que eles não tem mais 9.vergonha de canta e eles não cortão os cabelos como que os aluno que os cabelos como os cupe que eles se 10. amostra como qui.

1.Antes era todos das tradições da antigamente, nos vivemos pela tradição indígena que para conhece os 2.costumes de outros, bem diferente. 
3.E não tem que você índio vai se acabar a sua tradição. Eu conheço. A minha tradição a minha propria 4.palavra. E com os outros que e parecida e que e mas a mesma tradição ou mas do passado. Mas gostam da 5.minha tradicionaes culturais e constume.

6.Mas eu não vou largar vou sempre ficar perto porque e disso que a pessoa vivem em seus lugar

Texto 6

1.No passado nós passamos uma vida muito melhor antes dos Português chegada aqui.

2.E depois de 1900, começaram consequencia muito rara de contato, mais conflitos em ocupação de recursos 3.naturais.

4.PRESENTES

5.Ainda nós tem nossa cultura e preservando e aprendendo com os mais velhos que conta a história ontesico. 6.No que aprendeu com outro velhos. Temo 3002 mil hectásios de terra objetivo e preservar a naturizas.Tem 7.programa de saúde e educação e outas órgão governamentais.

8.FUTURO

9.Espero uma vida melhor para o meu povo. Para que seja de sucesso e paz e alegria. Não esquecem do 10.nosso modo de viver e reconhecido no iniverso com diversas contribuições físicas tais e profissional 11.entender os dois mundo

\section{Texto 7}

1.Os antigamentes os índios que viviam na terra eles sempre vinha mantendo a sua própria tradições mesmo. 2.Cantar no pátio correr com tora, caçar no mato, trabalhar nas roças enfim a nossa tradição era muito boa 3.antigamente todos dos dias ele ela pintar para a festa que faz nas aldeias. A gente usava genipapo para 4.pintar o corpo, também urucum para pintar igual o genipapo nós usava também pau de leitepara pintar também.

5.Em dia de hoje a nossa tradição indígena esta sendo extinto que tem muito jovens que está deixando de 6.utilizar a sua propria tradição indígena que venha sendo feito no passado. Mas na minha aldeia não tem 7.isso, sempre temos a nossa tradição propria mesmo mas tem vares aldeia que só estão perdendo a sua 8.tradição.

9.Mas eu penso no futuro eu não vou deixar meu povo perder a sua tradição

\section{Texto 8}

1.Povo krahô do antigamente fazer uma tradições a sim. tradições do povo krahô do antigamente fazer uma 2.corrida. E a pessoas ele vai cortar um tora. E a tarde de 3 jora e já ta na hora de corrida. Povo krahô do 3.antigamente todos mundo ele vai pum torrci. Em a noite e as pessoas ele vai chegandos e todo mundo vai 4.cantar. Agora vai terminar até amanha cedo. Em tem vários tradições povo krahô.

\section{Texto 9}

1.Antes meus povos eram muitos animados faziam tudo que eles quizerem fazer, cantava todas as noites 2.corriam todos os dias, fazem as festas todos os dias. Todos pintados e todos os cabelos cortados...

3.Mas hoje em dia os novos não faz assim como era ante. Hoje os novos não faz as festas todos os dias, faz 4.as festas de vez em quando, não cortar cabelo não pinta, não corre todos os dias corre de vez em quando ou 5.corre só no dia de festa...

6.Eu acho que no futuro filho não vai pegar esse tradição que nosso bissavô deixou para a gente.porque

7.ninguem vai querer cortar cabelo e pintar o corpo com jenipapo e urucu. Eu estou pensando assim

\section{Texto 10}

1.Lá na minha aldeia, eu corro todo dia bem cedo nunca eu vou deixar a minha tradição, sempre eu vou usar 2.a minha tradição e costume.

3.No futuro a criança não quero saber de correr com a tora e nem fazer festa na sua aldeia quer vira com 4.cupê. Porque nos já alimentamos a comida do branco só por isso, os mais velhos briga com a gente para 5.não virá com branco.

6.Os antigamente os velhos índios não usava roupa anda pelada nem vestir só faz a sua festa na aldeia corre

7.todo o dia, e casça e pesca e sempre está usando tradição mas forte ainda.

Texto 11

1.Sim Antigamente os índios velhos que não tem lugar certos para mora na aldeia.

2.Mais desqui e nós vivemos lá no fim do céu azul os outros velhos disse sempre estamos ouvindo. 
3.Mas premeiro os índios gostavam de muita festa para fica algre para corre mas premeiro. A gente vai 4.pintar com jenipapo e pau - de -leite e urucum. Quando vai para corre vai ser muito sol quente da atarde 5.mas sempre corre embaixo.

6.Mais agora nesses dia nesses anos de 2006 já ta quais índios não lembrou os costumes quando os 7.comunidade vamos fazer outros festa os juventude não ajudar de corre. Vai só olhar porque.

8.Eles não aprendio de corre so por isso não quer hojé dia tan só abasando cabelos e usam camisete para 9.anda trânsqueiro

\section{Texto 12}

1.Antigamente, as tradições do meu povo eram são mais avançada. Por que, quando eles vão iniciar alguns 2.festa, todo mundo vão ser pintado o corpo de qualquer jeito. Mas para pintar o corpo tem que ter jenipapo, 3.pau- de - leite ou urucum. E na verdade no passado o meu povo finalizem a festa com dansse da caças.

4.Atualmente hoje, sempre nós continua de relembrar-se a nossa tradições. Porque se não mostra para nós? 5.Então agente esquece, por isso sempre o meu povo continua de mostrar a tradições da nossa tribos. Mas 6.neste momento agente não pega a regra do passado.Agora nós estamos fazendo com diferente.

7.Na verdade, os novos que vão estarei no tempo vão passando cada vez mais. Vão aprender tudo que agente 8.fazem no presente ou no passado. Porque eles não vam corre, dacar,trabalhar com roça. Eles estão correndo 9.só atrás do cupê

\section{Texto 13}

1.Eu conto muito tradições dos antigamentes, porque naquela época eram preservado a cultura. $\mathrm{E}$ mesmo 2.assim que nós lembrando da nossa ritual. E até hoje nós joventude nunca vai esquecer a nossa cultura. E 3.até agora sempre que os velhos vai discutir no pátio ou no pensão. E fazer aquela festa e nós joventude vai 4.acompanhar, de corrida, dança no pátio. E nunca vão esquecer a nossa cultura.

5.E eu penso assim, eu acho criança que vem em depois, vai peder a nossa cultura. Porque já estavam usando 6.a camisa e short.

\section{Texto 14}

1.Antigamente, os povos indígena fazer a festa e todos pintarão no corpo com jenipapo e urucu passa no 2.corpo também E fazendo também chapel de folha de burite, coloca no pescoço também.

3.Só duas pessoa cortam a tora lá longir e povos só esperando eles quando chegarão o povos todos vai atras 4.de tora para pegar eles, voltam para aldeia.

5.Corridas de mulheres, homens, criança todos correndo com tora. Ne um ficando parado todos companhado 6.a tora.

7.Mas é cada partido tem inverno e verão qual partido ganhar com tora.

\section{Texto 15}

1.Eu vou fazer a redação sobre futuro, no meu pensamento que eu penso no futuro, como eu estou estudando 2.de português e matemática, ciência, geografia, e quando eu aprender de todos matérias que eu estudo na 3.escola, e depois eu começo ganha um emprego para trabalhar com próprio mehi, na aldeia cachoeira e para 4.devende meu povo.Só isso que eu estou pensando no meu pensamento de futuro. Porque os branco que 5.trabalha na aldeia que fica só brincando e só faz o projeto para as comunidade da aldeia, só por isso que 6.índio não que mas cupê trabalha na aléia, só índio que mais gosta de trabalha.

7.A da futuro nós são tribo krahõ não dexa nosso futuro, sempre nós representa nosso futuro.

\section{Texto 16}

1.Antigamente não tinha nada e os mahi andava nas aldeias, fazendo a festa todo dia, e anoite a gente cantar 2.com o maracá.

3.Só pensando de correr de amanhã bem cedo, não lembram a cidade só lembram a cidade só lembram a 4.aldeia e casada.

5.Antigamente só veve na aldeia, correndo com a tora de buriti. Só cuidar as famílias nas aldeias.

6.Mas hoje em dia os índios já aprendemos a cultura do cupê. Antigamente eu sou era nada, não percebendo 7.o que já repaçou. Antigamente os mais antigo saber tudo no século passado.

8.Não perco nosso instrumento nosso bisavô deixou. 
2.para agente almar, na hora da festa dos índios ninguém vestir roupa.

3.Todo mundo pintam co jinipapo, pau - de - leite e depois pintar com urucu, a gente faz chapéu de imbira.

4.E na hora de correr com a tora o chamador chama agente para juntar e correr, a tora fica no mato que 5.agente vai buscar e até chegar na aldeia.

6.A noite começar a cantar com maracá para as mulheres a companha aquele contador, mas tem muito

7.barulho de instrumento de busina,cabacinho e etc.

8. Essa que os tradição dos índios Krahô, não esqueça a nossos tradição.

Texto 18

1.Antigamente o índio que cantar todos os dias noite, cem para noite. Porque? Tem muitos cantor.

2.Hoje me dia cantora não vai cantar no pátio mas agora, em dia noites porque?

3.Cantar mas difícil cantar no pátio.

4.Hoje? Em dia não vai cantano no pátio porque?

5.Cantar mas difícil para festar. Hoje, para nós mas sim.

Texto 19

1.Na antigamente nós tradição era vive e era muitos a diferenciadas só os índios velhos usam os seus 2.costumes para não esquecer suas tradições sempre usava seus tradições.

3.Até agora os índios novos nunca esquecer as tradiçõe que os abisavós deixara para os filhos e netos.

4.Quando e antes de esquecer as tradição dos índios velhos

5.- Eles dizem para suas filhos e para outras pessoas que vivem na mesma aldeia.

6.Dizem assim meus filhos e meus parentes não vão perder a nossa cultura e as tradição, vamos relembrar do 7.nosso passado, que é nossa cultura ainda ta viver. Vamos cuidar da nosso costumes.

8.Até hoje os costumes, tradição, contoria, corrida, armas de flecha não ainda foi deixados. Por que a nossos 9.bisavós deixou para nós índios. Porque cada esses costumes tem suas próprias histórias , para relembrar os 10.passados tudo foi deixados para próximos filhos usarem e pensar no futuro o que ta possindo para chegar. 11.Que o mundo não tem fim. Até agora nós sempre relembrando os passados, nunca nós deixamos as 12.tradições dos kraolandios.

Texto 20

1.Antigamente os índios tinham tradição conservada, os povos fazem suas festas com muitos alegrias e 2.também ante suas florestas eram ricas de caças, pescas,flora,paisagem naturais etc.

3.Hoje me dia nós jovens conservamos essa tradição com bastante carinho, sempre nós fazemos festas para 4.poder lembrar a tradição do nosso bisavô.

5.Os futuros netos vão segurar os costumes e mantendo conservar a nossa língua, tradição, o jeito de viver, etc

Texto 21

1.Os povos Apãnjekrá premeiramente os velhos andavam nús, em culturamente deles, nas festas que tivemos 2.no tempo dos índios velhos em anjikim, torão, festa de peixe e ainda mais outras festa.

3.Agora os jovens já não usava aquela tradição que os velhos usavam premeiramente na cultura, mas 4.realmente a cultura continuava mesma em passado que os velhos faziam festa, correr a tora,prissão, batata, 5.gavião, pikahhoc, esta anjiki ainda existe todos em nossa cultura canela.

Texto 22

1.Antigamente os velhos cantavão no pátio alguma coisa ou história ai os jovens ter que participar no pátio 2.todo mundo josveis os velhos também

3.Quando velho manda todos nós nós companha aquele nosso leias as mulheres companha também porque 4.nosso leia e diferente nem tal igual com bancos não ai nós fazer alguns brincadeira nas aldeia ou 5.brincadeira de laranja ou brincadeira de peixe nós brinca até a noite inteiro ou até de amanhã termina seis 6.hora da amanhã. E também outros historio passado que os velhos contavos nos pátio para todos jovens . Eu 7.também participar todo dia.

8.Hoje eu fui para aldeias trabalharemos bastantes voltareis a tardes. Eu fui tomar banho ló nos rios voltareis 9.para casas a tardes .Eu fui goigas bolas la nos campos.

Texto 23

1.Os índio cantaram todos os índio no pátio ainda no futuro ainda Hoje a noite nós todos cantaram no pátio. 
2.No passado a gente correu todos mundo correu. As pessoas da minha aldeia gostam de pintar o corpo . No 3.pátio os jovens aprenderam as histórias de antigamentes.

4.Os mais velhos se reuniram no pátio para discutir algumas questões na semana passada.

5.Nas festas, nós cortamos o cabelo pintamos o corpo e corremos com tora.

6.No presente ainda existem atradiçõs de índios. A gente pintamos todos mundo no pátio cantando todos 7.juntos ainda hoje existem atradições.

Texto 24

1.No antigamente que Ijõ jajá comta esta história, primeiro, os índios anda em nu, com folha patras e 2.prafrente.

3.Os índios se alimentam em pau podri no antigamente, eles em vivem assim, anda mas eles se pinta, urucu, 4.paudi leite.

5.Também índios não esquece os usu deles nas festa, eles comes umas coisa só.

6.Mas hoje o índios não eram assim agoras, o índio se vivem milhor com arroz, farinha,carne, e tem vares 7.outras coisas para se viver hoje.

8.0 índio anda bem prontos com roupas bem prontos, calção, camisa e também nós índios falamos com cupê 9.meio milho.

10.São muito importante porque , nós índios esta acontecendo em cada aldeia de nós e eu não sei as outras.

11.Tem deles que estavam acabando o cultura des em próprio aldeia, com nem forca para propria aldeia,

12.como nem forca para propria comunidade

Texto 25

1.Antigamente vou conta a história para vocês os mais velhos juntarão pátio e conbinariam como que a festa 2.começa o primero ou a festa de witi ou de laranja. Aí a gente vão fazer a festa todo mundo pintarão com 3.pau de leite ou de jenipapo outro pintam com urucu vão para a onteque a tora fica que outra pessoas 4.contaram para homem mulheres.Quando nós corremos depois a noite também as mulheres cantarão os 5.homens fica na frente das mulheres.

6.Mas hoje sempre os homens juntamos no pátio conbinavam a fazer a festa mais os jovens não escutavam a 7.comunidade o que as comunidade estão fazendo. Por isso pore enquando a gente não escutavam e nem 8.respeitando outro não e pintar e nem cantam os mais velhos falaram por novos da conselho por moça, 9.jovens porque as moças não cantavam sabe nada o cantiga o que quer os mais velhos cantam. Mas sempre 10.os mais novo esta fazendo a festa e da cultura

Texto 26

1.Bom antigamente a nosso tradições bem organizada, pelos mais velhos, o cantor, e cacique, governadores, 2.são mandado pelo festa de qualquer tipo festa de tradições, costumes, corrida de tora. Todos mundo vão 3.participa festa, tora pra ter alegrea do povos, as crianças, adulto,muleres, e homen, mas a tora que mais dá 4.alegria para todos comunidade no krî é chama parti é uma tora de batatas, que todos, adultos homem e 5.crianças deve ter paparuto, Pra comer lá no pátio, e dicudir que todos ganhar iguais, as adultos crianças 6.depois leva pra casa e a mulher também vai comer .

7.Então esse tipo festa de torão, tem dentro paparuto, são misturado. Então a gente preserva ainda muitos 8.mimos. Olha nós somos povos Ananjekra faz festa bem organizada. Hoje em dia tantos antigamentos, tanto 9.faz em 2006, usa nosso tradições fortes.

Texto 27

1.Quando meu povo gavião fazer uma festa todos homens vai para a corrida de tora mas os velhos que vai 2.cortar essa tora eles fala para os jovens olha já que vocês comessaria a cultura de nossu bijavo nós 3.cantamos principais musicas.

4.Eu venho canta com todo que aparesen na verdade com as mulheres por que elas tira a fruta que a terra dar 5.para todos nós índio temos genipapo urucu e sua artesanato para enfeitar o corpo.

6.O povo da aldeia governador fazer a sua caçada pelo aquilo que nossa bijavo fazia antigamente pela mata. 7.Eles matavam muitas caça na verdade quando todos ssai pra a sua aldeia só uma pessoa vai canta para as 8.mulheres

Texto 28

1.Antigamente o meu povo canta no pátio a noite inteiro para que eles não esquecer da cultura tradicional 2.que os mas velhos encinaram para eles, e quando começa a festa tradicional todos vão para o patio.

3.Hojé os mas jovens não faz mas as festa tradicional porque nem todos vam para o pátio, mas os mas velhos 
4.vam para o pátio e eles já se proucupa com os jovens.

5.Os velhos contador se preocupa muito porque se eles morrerem os jovens vão perder os costume 6.tradicional porque eles não vão para o pátio não que aprender, os costume cultura e rituais, deles. Por isso

7.que os velhos se preocupa com os jovem hoje

Texto 29

1.Tradição passado até, Porque nós seguindo nossa tradições antiga que os mais velho tem para repassa para 2.os mais novo, té conhecimento rituais passado.

3.Preservamos a nossa tradição para ser o futuro do que ainda vai crescer, pensamos isso.

4.Os mais velhos, mostram tudo que sabe para os mais novos aprender e preserva as nossas cultura, pintura,

5.correr então até agora nós temos a nossa tradição preservada.

6.Brincadeira a corrida de tora de flecha cantamos tudo isso é nosso tradição preservada.

7.Nós povos brasileiro temos tradição preservada

Texto 30

1.Eu vou contar uma história que meu avô contou para mim, como era a vida deles no passado.

2.Bom a vida do meu povo era tranqüilo, eles caçavam, pescavam e levavam uma vida boa.

3.Antigamente, quando não tinha cupê, tinham muitas caças, peixes, frutas terra fértil. A cultura era muito 4.mais forte as nossas línguas, os costumes, as cantigas, músicas, festas, comidas e outros.

5.Hoje, atualmente tudo está diferente para nós. Com a chegada de homem branco, as caças acabaram, tem 6.caças mas poucos, as frutas estão poucas, peixe, madeiras para fazer casas.

7.E a cultura nossa está comprometida por causa de energia, gravador, rádio, roupa, dinheiro, comidas do 8.cupê e muitos costumes de cupê que é praticada na aldeia como futebol e etc.

9.No futuro não sei o que vai ser de nós se vai ficar bom para nós ou não.

10.Espero que nós os jovens de todas as etnias lutem pelos nossos direitos, assim teremos uma vida boa 11.tranqüila para nossas crianças e netos

Texto 31

1.Nós contamos dos antigos como eram os índios, usava cola, pulseira e outro para eles fica efeitado. 2.Correram vários a volta, em torno da aldeia até também, usavam cabasinha, flantar, maracá, e outros 3.instrumento para o uso. Até que eles ficaram assim continuando a mesma.

4.Bom como sempre eu gosto muito da cantiga corre com tora, mass de $50 \mathrm{kl}$ ou mais. O nosso gostume é 5.muito importante, mulheres, homem tem dias para corre com a tora crianças também corre cantar também 6.na aldeia ou no pátio.

7.Hoje agente corre com toras a partide agora nós nunca esquecemos a nossa cultura. Que faz felicidade para 8.agente e se alegra e divertir juntos com meus grupo.

Texto 32

A realidade do Indio
1.Antigamente os índios deste primeira década dos anos anteriores, não existia os brancos nessa terra, existia

2.so índio, e naquela época os índios tem própria sua cultura, eles andavam nu pintado com tinta de jenipapo, 3.urucum com colares bonitos com sua cultura rica.

4.Mas 1.400 anos atras começou contatos e massacre com índios aqui no Brasil que não existia esse nome 5.ainda, e como eram antigamente os brancos acroaticamente alienável acomodadamente com os índios eles 6.fizeram revolução política e os índios modificou a realidade na media estrutura, uma parte pouca civilizado 7.e uma boa parte existe propria será sua cultura ainda.

8.Mas eu fico preocupado sempre, porque as vezes daqui a 100 anos pra frente todos índios vai virar brancos 9.e não vai mais existir índio puro, mas hoje por enquanto existe propria cultura ainda, e nós que somos 10.índios, eu sempre ouvi alguns índios falar que está preocupado com a cultura para agente não perder 11.nossa cultura.

\section{Texto 33}

1.História da aldeia Escalvada, que mais contato pela através dos velhos e antigamente.

2.Na época foram grande com tradições de festa e cultura indígena, quém é descobrir para a situação o povo 3.falar do awkê, história do abisavos que ficou no tempo e anos atrás.

4.Quando eu lembrei dos antes, estava aconteceram e lugares, aldeia os velhos fez reunião a todo 5.comunidade acordo de acaba e matou awkê. 
6.Capacitação da festa e pintando de mulheres e homem jovem, agora mais diferente do mehĩ

Texto 34

1.Bom, antigamente tradições eram muito bom, todo mundo pinta de urucu pau-de-leite cortar cabelo e quais 2.todo mundo fura as orelhas, mais ao menos 30 pessoas, e quais todo mundo canta, mais ou menos 60 3.pessoas que cantam. Mas só tinha 6 cantores profissional que canta no pátio com maracá para as mulheres. 4.Mas hoje, como somos novo, não são todos que sabe cantar, são poucos, mais de 10 pessoas. Tem ainda 30 5.cantores profissionais que canta, 2 canta de maracá no pátio, 1 canta na casa de wy ty que é Rainha. Hoje 6.poucos que usa a pintura, não é todo mundo, pouco corta cabelo, pouco fura orelha e pouco são corredor, 7.mas nós ainda estamos usando as tradições.

8.Mas nesse ano 2006 pra 2007, fizemos novo plano pra nós não perder as tradições cultura e festas que está 9.acontecedo.

10.Nós preservamos e seguramos para eles usarem para frente

Texto 35

1.Antigamente na minha aldeia tinha o conto indígena, tinha corrida de tora a corrida flecha e tinham as 2.pintura para o corpo e também festa dos povos para pode, ou corrida de faze ou cantadores. Até tinha pena 3.de pasaro [...] pintura e também tinha festa dos pexe faz paparuta angente canta até de manhã agente vai 4.destribui o que que vam comer de manhã é paparuta.

5.Agora outra coisas os mais velhos contar então quando você namora com qualqué as menina se pura-causa 6.se você corredo você vai ne dorme na casa você dorme no pátio com folha de sucupira pra poder mais forte 7.e sente ne cusono.

Texto 36

1.A tradições do povo apinajé no passado os mas velhos contam que a cultura era mais valorizada fasiam 2.varias festas cultural, festa de caçada, festa de peixe, festa de tora, festa de batata, festa de milho, festa de 3.pintura, etc...

4.foi assim que os mais velhos contam do passado.

5.Nós apínajé estamos deixando de fazer algumas festa mas estamos recordando tudo denovo esas festa para 6.os mas novos que tão crescendo. O povo apinajé sempre estão preservando a cultura nunca vamos deixa de 7.ser índio sempre vamos preserva a nossa cultura no futuro e recorda o passado para os joveis.

Texto 37

1.No antigamente os índios faziam suas tradição de viver, e fazer suas culturas, no passado os índios 2.gostavam muito de usar muitas tentais, de jenipapo para usar no seu corpo para ficar bonitas. para usar 3.também o urucu no corpo.

4.para ficar vermelho. para dança na festa de mehẽ, e para correr com a tora no passado os índios gostavam 5.muito de pintar com as tintas de jenipapo e com urucu para não esquecer das suas festas e da sua tradição 6.de viver com seus gostumins

Texto 38

1.Antigamente na minha aldeia tinham os costumes dos cantos, cantorias indígenas, tinham a corrida de tora, 2.a corrida de flecha e tinham as pinturas corporais, as festas dos presos, faziam artesanato, arco e flecha, 3.faziam colares e saiotas isso era antigamente.

4.Hoje na minha aldeia nós já perdemos quase todas essas tradições. Tudo isso por causa do contato com os 5.não índios. Hoje nós só corremos com tora e praticamos muito a pintura corporal e fazemos ainda arco e 6.flecha fazemos alguns colares e algumas saiotas.

7.Só que nós estamos fazendo a corrida de tora, a corrida de flecha, a pintura corporal porque se nós não 8.praticarmos mais iremos perder de vez todas essas tradições, estamos tentando trazer de volta as nossas 9.tradições para a nossa aldeia. Porque mais tarde todos irão perder mesmo e nós iremos sempre praticar.

10. Nós estamos com um projeto para trazer de volta as músicas tradicionais.

Texto 39

1.As tradições do meu povo no passado é muito bom: porque homem e mulher corre com a tora quando 2.chegar na aldeia começa a canta esse é nosso tradição e ritual que a gente tem na aldeia. O povo trabalha de 3 .grupo na roça para ter muito alimento. 
4.E no presente o meu povo não trabalha mas em grupo, cada um trabalha para ter de alimentação e também 5.cuida da família de casa. Quando o povo canta no pátio as moça e rapaz não chega para canta alguns 6.cantos, o povo não dá valor por nossa tradições.

\section{Texto 40}

1.Antigamente os mais velhos, cantarão todos dia no pátio, e correm com tora de manhã e a tarde. Porque 2.antigamente as tradições é muito valorizada, que a te hoje nós nunca vamos esquecer a nossa cultura.

3.Mas quem sabem as crianças que vem nascendo eles poço esquecer a nossa tradição Até agora a gente já 4.esquecerão muio cantiga, que os velhos, cantarão a noite no pátio.

5.Mais agora tem alguma que canta a nossa cantiga.

6.E com certeza que vai acabar a cultura do índio. Porque já tem muita gente que já perderão própo tradição 7.deles. E eu ficar com preocupado. 
Imagem 5 - Bacia Hidrográfica do Rio Tocantins

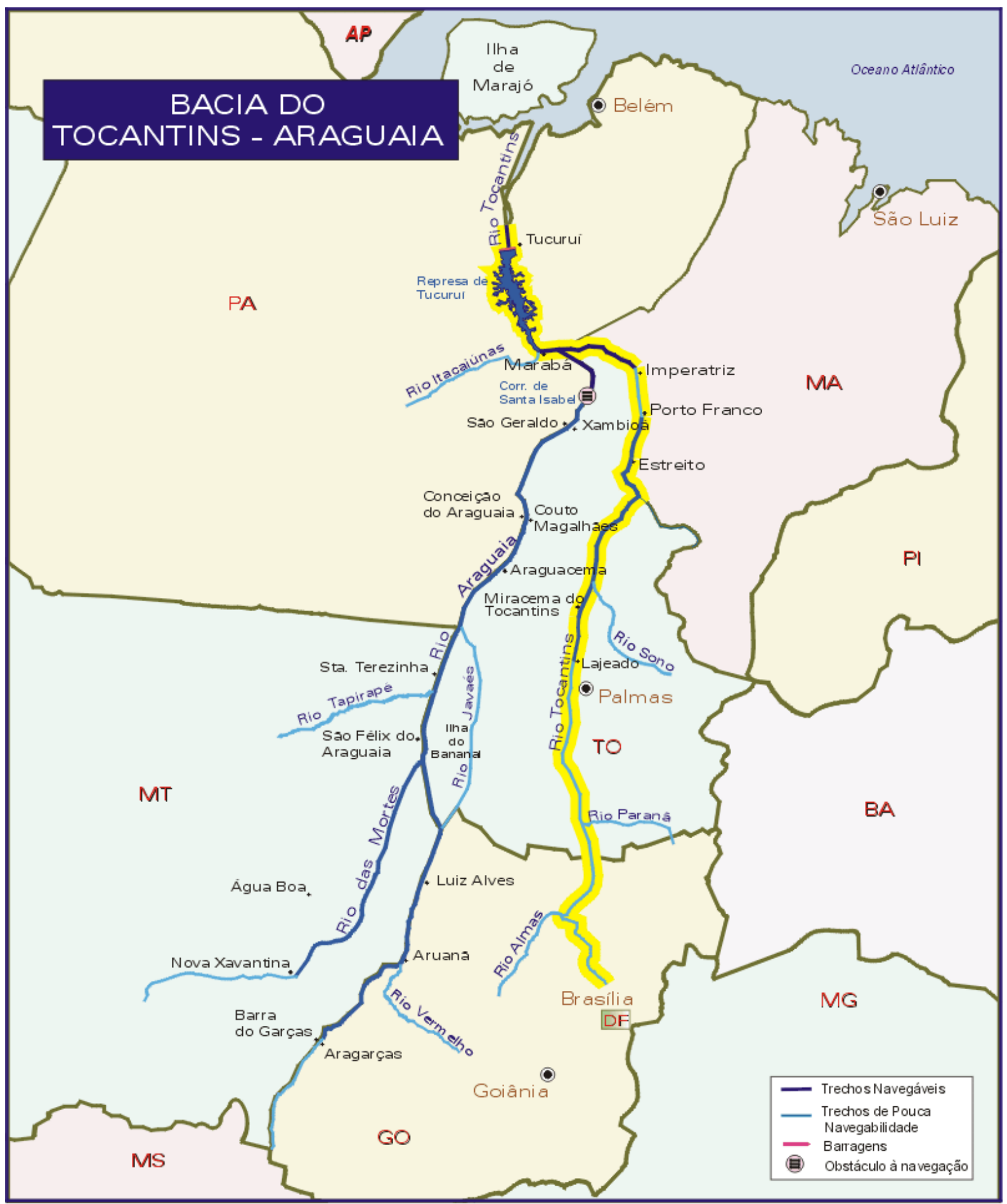

Disponível em: http://www2.transportes.gov.br/bit/hidrovias/Figuras/I-tocantins.htm 
Imagem 6 - Aldeias Timbira e vizinhas, imagem retirado de Nimuendaju (1946), sublinhados nossos nas tribos Pykobjê ("Pukobyé"), Guajajara ("Guajajára") e Krinkati ("Krikati”)

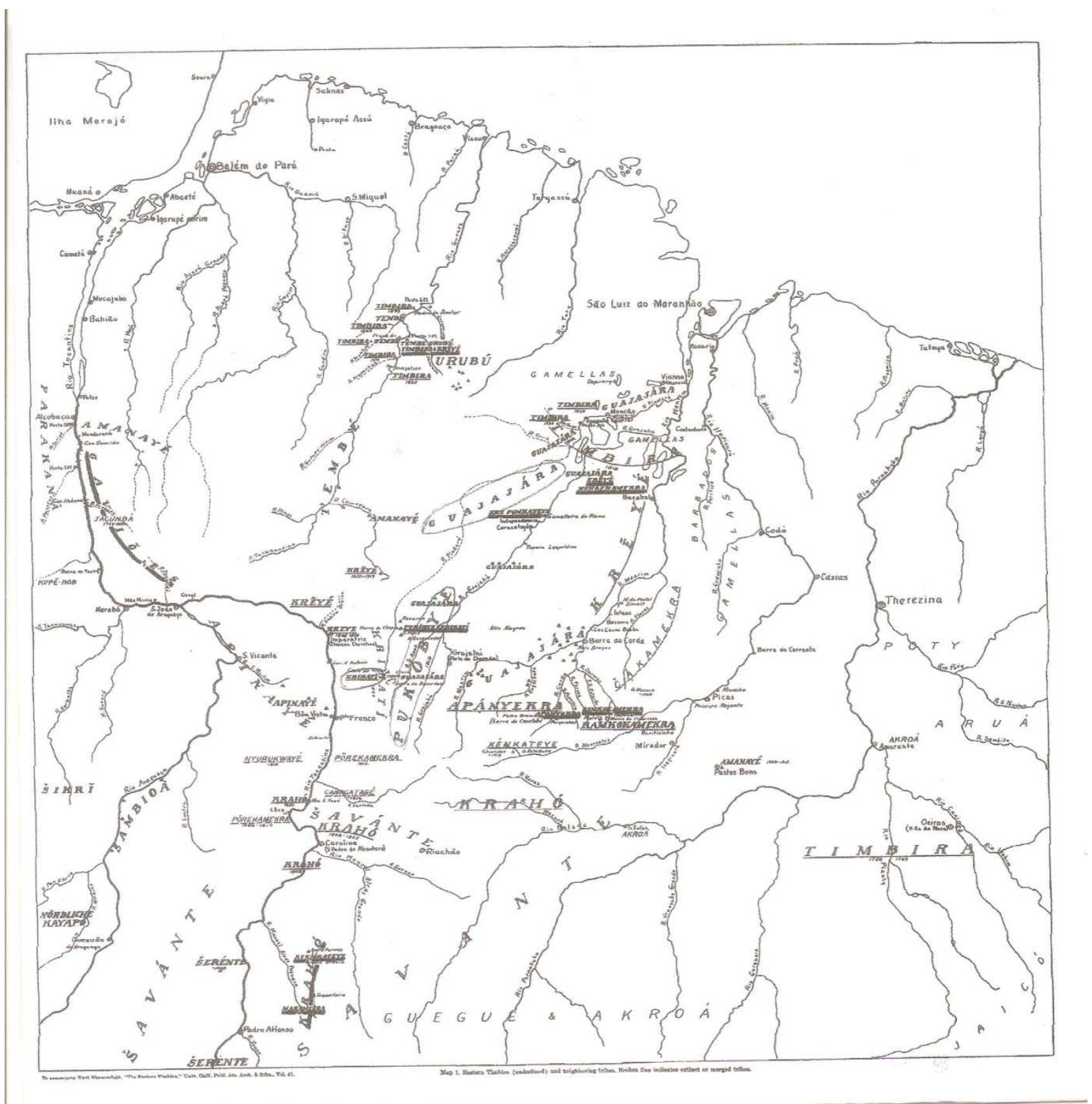

